\title{
A Union of the Inkpot: \\ The Canadian Authors Association, 1921-1960
}

by

Christopher M. Doody

A thesis submitted to the Faculty of Graduate and Postdoctoral Affairs in partial fulfillment of the requirements for the degree of

Doctor of Philosophy

in

English Language and Literature

Carleton University

Ottawa, Ontario

C) 2016, Christopher M. Doody 


\begin{abstract}
This dissertation examines the development of authorship in Canada in the first half of the twentieth century, with a particular emphasis on the Canadian Authors Association (C.A.A.). By focusing on this association, the dissertation refutes the common narrative that the development of Canadian authorship was the result of a vanguard of modernist writers standing collectively against an older generation of amateur writers. Instead, it insists on the importance of a history of authorship that includes dissenting conceptions, specifically those articulated by the C.A.A., which resisted the practice of creating hierarchies for authors based on gender, age, quality of work, chosen genre, or professionalism. The development of authorship in the first half of the twentieth century was a site of debate and contestation. From 1921-1960, there was increasing pressure to define this key role in the national literary field. This pressure to define authorship was manifest: in the legal debates around copyright, which had ramifications for both the state and for private industry; in the debates between authors themselves, as seen during Book Week (1921-1957), which sought to determine the proper relationship between literature and the marketplace; in the creation and development of the Governor General's Literary Awards (1937-1959), in which the association attempted to promote a specific type of literature; and in the rise of government patronage of the arts, which saw the state developing new ways to both fund and regulate culture. During these various debates over the role of authorship, the C.A.A. generally resisted hierarchies, and in doing so defended the middlebrow and the writer as a skilled labourer in the literary field. The association, however, was not always consistent in advocating these positions. This
\end{abstract}


inconsistency demonstrates how difficult it was during this period to articulate a single, coherent definition of authorship. As such, this dissertation argues that literary histories that only recall the modernist narrative of the rise of authorship in Canada lose a sense of this important contest. 


\section{Acknowledgements}

I would like to express sincere gratitude to Dr. Jody Mason for her supervision of this dissertation. I am indebted to her for sharing her wealth of knowledge, for her insightful comments, and for her constant support of this project. I am also grateful to Dr. Sarah Brouillette for supervising my dissertation research project, to Dr. Jennifer Henderson for supervising my comprehensive studies, and to them both for providing useful feedback on my dissertation. I also wish to thank Dr. Carole Gerson and Dr. Paul Litt for agreeing to act as external examiners and for taking the time to participate in the defence.

I am indebted to Dr. Paul Keen for employing me as a research assistant during my final year. This project was supported financially through a Joseph-Armand Bombardier Canada Graduate Scholarship, an Ontario Graduate Scholarship, a S. F. Wise Graduate Fellowship, a Hamlin Graduate Fellowship, and a Graduate Research and Innovative Thinking award.

I am especially thankful to my colleagues that have supported me and my research. In particular I want to thank Alexander Grammatikos, Andrew Connolly, Eric Schmaltz, and Shaun Stevenson, who have all listened to me talk about this project, have read sections and provided feedback, offered useful and necessary criticism, and most importantly, have been constant friends.

The support of my family has been invaluable to me through this process, and I am thankful to them all. Penny, I could not have asked for a better writing companion; your silent support does not go unnoticed. 
This project would not have been possible without the loving support of my wife Jessica. Not only has she supported us financially but she also spent countless hours reading and editing this dissertation. She has shared my frustrations, celebrated my successes, and been unwavering in her encouragement. I owe her more than I can adequately express. 


\section{Table of Contents}

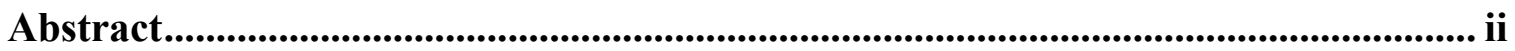

Acknowledgements ....................................................................................................... iv

Table of Contents ......................................................................................................... vi

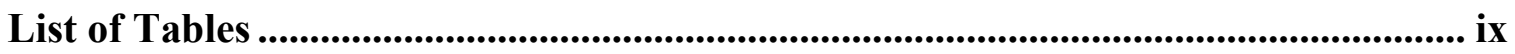

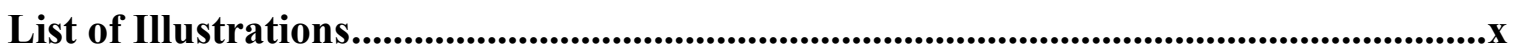

List of Appendices.......................................................................................................................... xi

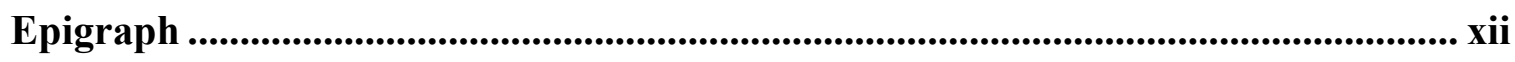

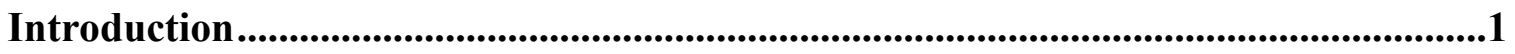

The Founding of the Canadian Authors Association ....................................................

The C.A.A.'s Legacy ........................................................................................

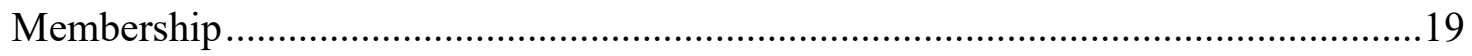

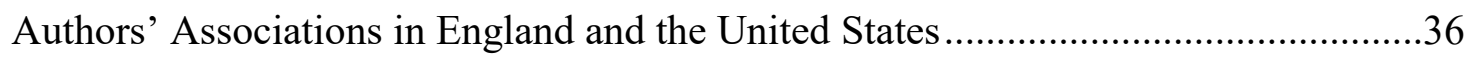

Authorship Studies in Canada ....................................................................44

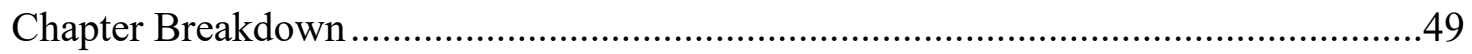

Chapter One: Copyright Reform and Canadian Book Week ...................................52

The Road to Montreal: The "birth [of] a new profession" ......................................55

“A Very, Very Troublesome Question”: The Fight for Copyright .............................60

Authors “Treated Like Dogs": Copyright Enacted ..............................................69

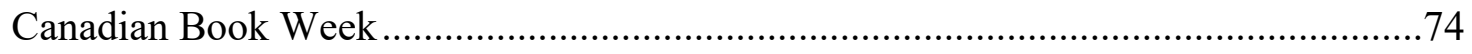

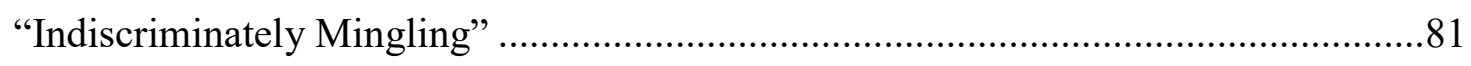

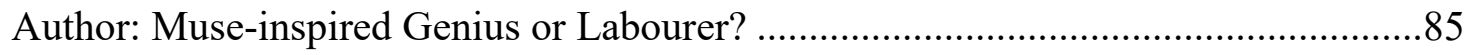

Book Week: Just Another Name for "Materialistic Patriotism”? ..............................95 
Conclusion.

Chapter Two: The Governor General's Literary Awards..........................................101

"Raising the quality of our work:" From Copyright to the GG Awards ....................110

The Creation of the Governor General's Literary Awards.......................................119

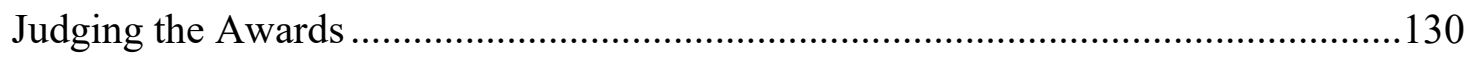

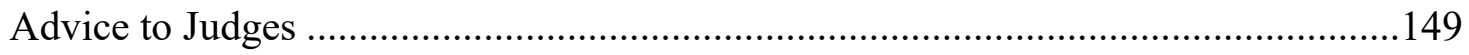

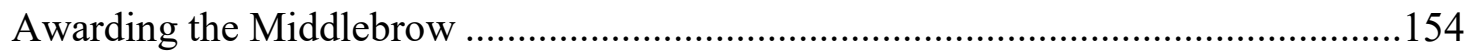

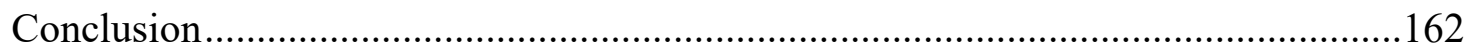

Chapter Three: The Rise of Government Patronage for the Arts ...........................165

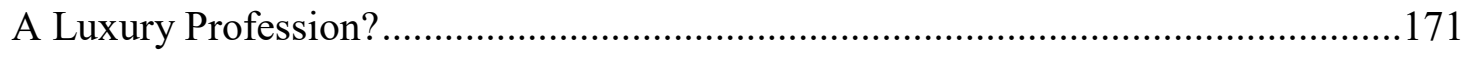

Artists March on the Turgeon Committee .............................................................. 175

Reporting on Authorship: Briefs Submitted to the Royal Commission on National

Development in the Arts, Letters, and Sciences ........................................... 187

"Culture has this in common with underwear and fur coats - it costs money": The

Massey Commission's Report ...............................................................221

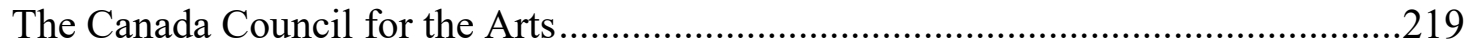

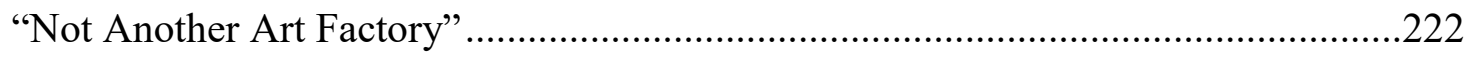

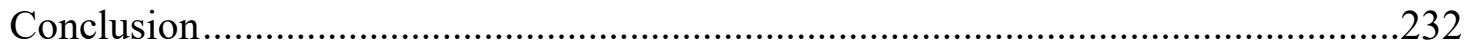

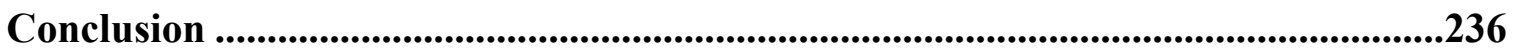

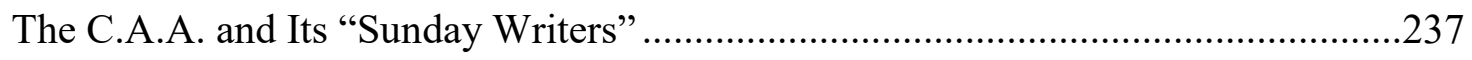

Authorship and the Royal Commission on Book Publishing ..................................239

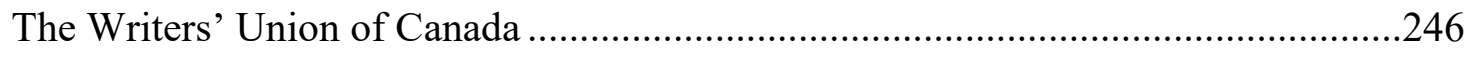

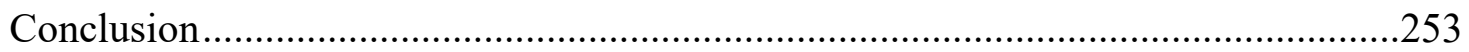




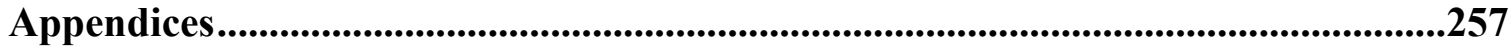

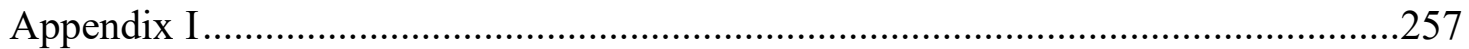

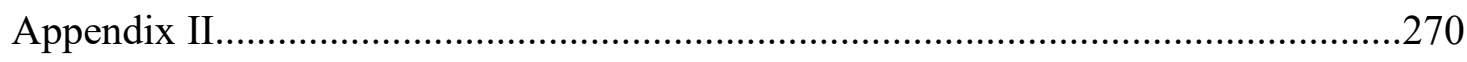

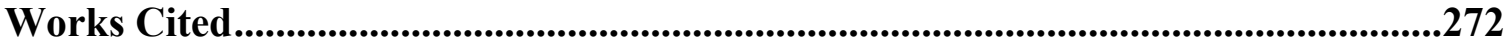




\section{List of Tables}

Table 1: Overall Membership of the C.A.A. (1921-1953) ............................................31

Table 2: Membership of the C.A.A. by Gender..........................................................

Table 3: Per cent of Women in Regular and Associate Membership from 1924-1933 .....32

Table 4: Amount of Grant Money Given to "Writing" by the Canada Council ..............220

Table 5: Distribution of Canada Council Funding from 1957-1967..............................221 


\section{List of Illustrations}

Illustration 1: Portion of cover of Canadian Bookman, December 1921 .........................76 


\section{List of Appendices}

Appendix I: Judges of the Governor General's Literary Awards from 1937-1959 ........257

Appendix II: Point System for Evaluating Votes of the Judges .................................270 
[L]ast month, in the city of Montreal, I saw more than one hundred honest-to-goodness Canadian poets and authors gather together for the purpose of forming a sort of union of the ink-pot. They were there like bees about a syrup-barrel, pen pushers from the western provinces, expatriate novelists from New England, story-tellers from Nova Scotia, magazine-writers from the banana-belt of Ontario, silver-tongued poets from Quinte and Old Quebec, scholars and philosophers from the universities, and even publishers and magazine-makers from the sister-city of Toronto. They were there to get unionized and have walking delegates and grievance-committees after the manner of the plumber and the locomotive-engineer. They were very serious about it all. And as I listened to that solemn talk of theirs it suddenly came home to me that a new age had dawned for Canada. There, before my eyes, she was giving birth to a new profession. She was publicly and officially acknowledging that her authors were a body of men and women to be reckoned with, to be listened to, and perhaps some day even to be legislated for.

- Arthur Stringer 


\section{Introduction}

In the second volume of their 2009 anthology, Canadian Literature in English, Laura Moss and Cynthia Sugars recount a familiar narrative: "The 40 years between 1920 and 1960 saw significant changes in Canadian culture, society, technology, foreign policy, national identity, and, concurrently, literature" (1). This change to literature, we are told, "was a result of a generation of writers who actively rejected both the driving aesthetics and the prevailing ideologies of the previous generations in favour of something more recognizably modern in subject matter, tone, and form. There was also a push toward artistic independence and an acknowledgement of the need to unhinge Canadian writing from a colonial mentality" (1). This narrative, and others like it, suggests that the changes that took place in the literary field in Canada during these forty years were the result of the endeavours of modernist writers. While well known, this narrative is simplistic. It implies that Canadian authors were more or less homogeneous in their ways of thinking about literature, with the new vanguard collectively standing against the older generation of writers. Furthermore, it diminishes and excludes the role played by authors who did not abide by the modernists' view of literature. Contrary to this popular narrative, Canadian authors were neither in agreement in their thinking about literature, its role in society, nor its relationship to the marketplace. This dissertation examines the literary field over this forty-year period, focusing particular attention on the various and competing understandings of authorship that resulted from these differing views of literature. In doing so, it resists and challenges the literary history of Canadian modernism, by insisting on the importance of dissenting conceptions of authorship in this 
history. Specifically, it questions the hierarchies established and supported by modernist writers that positioned some authors as superior to others, and some genres as superior to others. In order to challenge this history and its accompanying hierarchies, this dissertation focuses on the Canadian Authors Association and its commitment to the idea of the author as labourer, in which all writers are worthy of support, and its support of the middlebrow, in which commercial success is both acceptable and desirable. The association, however, was not always consistent in its commitment to resisting hierarchies, demonstrating the intense contest surrounding the attempt to define authorship in this period. Therefore, in recalling only the modernist narrative of this history we lose a sense of this complicated contest.

These conflicting, and highly debated, conceptions of authorship in the first half of the twentieth century in Canada are the focus of this dissertation, especially as they were articulated by the Canadian Authors Association (C.A.A.). ${ }^{1}$ The Canadian Authors Association has almost been written out of Canada's literary history. Founded in 1921, and still active today, the association's most important work was arguably done in the first forty years of its existence. During those years it lobbied the government for changes to copyright laws that disadvantaged Canadian authors, organized a yearly nation-wide book week (1921-1957), published the Canadian Poetry Magazine (1936-1963), created and ran the Governor General's Awards (1937-1959), and was active in lobbying the government for patronage of the arts. Throughout these various initiatives to strengthen the position of Canadian authors, the C.A.A. had to articulate and defend its conception

\footnotetext{
${ }^{1}$ There appears to be no rhyme nor reason as to whether it is spelt "Authors Association" or "Authors' Association." Even on official C.A.A. letterhead the apostrophe disappears and reappears seemingly randomly over the years. For consistency, this dissertation will spell it without the apostrophe, while retaining the original spelling in all quotations.
} 
of authorship — one that was based on supporting all authors, regardless of gender, age, quality or style of work, that wanted authors to be paid a fair wage for their labour, and believed strongly in the national importance of a uniquely Canadian literature. In exploring how this conception of authorship was developed and defended, often against the conception of authorship expressed by Canadian modernist writers, this dissertation argues that there is a need to reconsider how authorship was understood in Canada during the first half of the twentieth century.

\section{The Founding of the Canadian Authors Association}

Late in 1920, Stephen Leacock, internationally renowned author, B. K. Sandwell, editor of the Canadian Bookman, John Murray Gibbon, author and head of public relations for C.P.R., and Pelham Edgar, author and professor, met to discuss the recent proposed changes to the Canadian copyright law. ${ }^{2}$ Gibbon would later call this meeting "an indignation tea-party" (5), as the four writers were distraught by the suggested changes, which they feared had the potential to financially disadvantage Canadian authors. Most accounts suggest that Leacock was the most upset, and "was up in arms" (Gibbon 5), because he feared that the new law could have a direct impact on his financial success, since his books were all published in the United States. ${ }^{3}$ Ralph Curry, Leacock's biographer, however, suggests that these four authors "were of sufficient literary stature,

\footnotetext{
${ }^{2}$ Sources do not agree when this original meeting took place. Curry, for example, states that it happened "Late in the summer [of 1920]" (145), while A. Moritz and T. Moritz state that it happened "in the fall of 1921 [sic]" (195), although it is clear that it must have occurred near the end of 1920.

${ }^{3}$ The copyright situation is explained in more detail in the first chapter, but in essence, the proposed copyright bill gave Canadian printers the ability to print Canadian books that were originally published outside of Canada, without acquiring the author's permission. Under such a law, Leacock feared that his sales in the Canadian market would be undermined by new, "unauthorized" Canadian editions.
} 
particularly Leacock, that their reputations might protect them" against the proposed copyright changes, but they were outraged on behalf of other Canadian authors "who would certainly suffer" (145). Either way, the four authors, "With the aid of postprandial libations," came to "a decision to protest against the offending [copyright changes]. It was agreed that an expertly organized and publicized dinner, to be attended by as many Canadian writers as possible, ought to gain support for the campaign" (Legate 112).

Soon after, F. W. Wallace was added to the organizing committee, and the dinner was expanded to a two-day convention. To publicize the convention,

Notices were published in the press, in all parts of Canada, intimating that the convention would be open to all Canadian writers, or writers domiciled in Canada, who were interested in the protection and advancement of the craft of authorship; and personal notices were sent out to some eight hundred persons whose names were known to the organizing committee or were suggested by others as being those of persons likely to be interested in such a convention. Every effort was made to convey the clearest possible impression that the convention was not an invitation affair, and that the sole object of the committee was to obtain the largest possible representation of practicing Canadian authors of every kind, class, and geographical and racial division of the population.

(“Convention" 8)

This convention took place at McGill University on March 11-12, 1921, with over one hundred writers in attendance. The convention was originally scheduled to take place at the University Club, but had to be switched to McGill's Old Medical Building due to the unexpectedly large number of women writers who attended the convention. As Gibbon 
notes: "The promoters were all men, and their surprise was considerable when the replies proved that the majority of the authors were women. This discovery was also embarrassing, as the available space in the ladies' section of the University Club was at the time little more than a cubby-hole" (5). Although the convention was originally planned to simply discuss the proposed copyright changes, the night before it was set to begin, Pelham Edgar suggested that the convention should be used to create a more permanent organization of Canadian authors. The other members of the organizing committee agreed, but that meant writing a constitution for the proposed organization overnight. Gibbon, "In a misguided moment ... admitted that [he] had a copy of the Constitution of the Isaac [sic] Walton League of America, and said that perhaps it could be adopted" (5) and agreed to write the constitution overnight. Gibbon, however, quickly realized that the Izaak Walton League, as an environmental protection organization, had little to do with authors. As Gibbon notes, "I realized the difference between fishing and book-writing. All I could get out of the fisherman's Constitution was that it was broken into paragraphs and sections and subsections and by-laws. The result was that I had to sit up all night to concoct something more to the point" (5). ${ }^{4}$ Louvigny de Montigny completed the French portion of the Constitution. At the convention, the Constitution passed, Gibbon was elected as the first President, and the Canadian Authors Association was founded.

The association had a unique structure, with a National Executive Committee that was responsible for the association at a national level, and local branches in large cities across the country, which were responsible for organizing all of the association's local

\footnotetext{
${ }^{4}$ Ralph Curry recounts a more humourous version of events: "Murray Gibbon always claimed that they took the constitution of a fishing club he belonged to and spent the night changing the word 'fish' to 'book,' and 'fisherman' to 'author,' and 'fishing' to 'writing'” (147).
} 
events. When the association began in 1921, there were local branches in Toronto, Montreal, Ottawa, Winnipeg, Edmonton, Calgary, and British Columbia (with headquarters in Vancouver). As the association expanded, dozens of other cities opened their own local branches. This unique structuring had some advantages. As an article in the Canadian Bookman notes in 1921, "The surprisingly large attendances at each of [the preliminary meetings of the various branches] and the enthusiasm which developed as soon as it was realised that the branches were to be self-governing leave no doubt as to the future of the new Association" ("Gathering" 22). The C.A.A. stressed that "The life of the Canadian Authors Association depends not on the activity of the Central Office but on the vitality of its branches" ("Gathering" 22). This emphasis on the importance of the local branches is echoed in the C.A.A.'s various official publications, ${ }^{5}$ in which large sections were often dedicated to news from each branch, to ensure that members were kept informed on what the other branches were doing. For nation-wide events, such as Book Week, the National Executive would organize the event with other members of the book trade and would give interviews to the media, while the actual local events would be decided upon, and organized by, the various local branches. The autonomy accorded to the local branches allowed for diversity, in a variety of ways. Some branches were very small, while others were large; some branches specialized in poetry, while others

\footnotetext{
${ }^{5}$ Literary historians often associate the C.A.A. with the Canadian Bookman. This is understandable as B.K. Sandwell, one of the founding members of the C.A.A., was the editor of the Canadian Bookman in 1921, and used the magazine's resources to help recruit authors to the inaugural meeting of the C.A.A. The Canadian Bookman, however, was only the official organ of the C.A.A. for less than two years: the Canadian Bookman became the official organ of the C.A.A. with its June 1921 issue (3.1), and the November 1922 issue (4.11) was the last issue of this arrangement. After this issue, the Bookman still ran news about the C.A.A., but almost exclusively in a section at the back of the magazine, and the C.A.A. had to buy this page space each month. This arrangement with the Bookman continued until 1931. As well as this section in the Bookman, the C.A.A. continued to have its own official publication. After the Bookman, the C.A.A. launched the Authors' Bulletin (1923-1933), before renaming it to the Canadian Author (19331940). In 1940, the C.A.A. (re)acquired the Canadian Bookman and merged it with its own publication to form the Canadian Author and Bookman (1940-1992). For a more detailed history, see "Thumbnail History of the Canadian Author \& Bookman."
} 
supported a wide array of genres; some branches were actively involved in their region, while others played an important national role. As a result, each branch acquired its own interests and desires, as can be seen in the various reports each branch made in the C.A.A.'s various official publications.

The most independent branch of the C.A.A. was the French section of the association. A month after the C.A.A.'s creation, on April 17, 1921, thirty Quebec authors gathered at the Bibliothèque municipale de Montréal to lay the foundation for the French section. Josée Vincent explains that a few of the gathered authors were hesitant about joining the C.A.A.: “certains entrevoient d'un mauvais œil l'état de subordination à la fédération anglophone" ("Un premier” 289). Olivar Asselin was the most vocal against joining and suggested that the gathered Quebec authors should start their own association. Asselin, however, was outvoted as the majority of the authors supported joining the C.A.A. because of the association's national infrastructure, and the hope that belonging to the C.A.A. would allow Quebec authors to gain recognition throughout Canada (Vincent, “Un premier" 289). The gathered authors met again on May 1, 1921, to sign an agreement to officially join the C.A.A., on the condition that: "en tant que section canadienne-française autonome et indépendante quant à son mode d'administration, avec une voix délibérante au chapitre fédéral de l'Association dans une proportion équitable" (qtd. in Vincent, "Un premier" 289). This desire for independence within the C.A.A. can be seen in early issues of the association's various publications, as each issue had several pages dedicated to the French section. Despite this autonomy, the French section was still forced to adhere to the regulations and constitution of the C.A.A., including paying a per cent of membership fees to the national executive. In 1935, Jean 
Bruchési and Albert Lévesque sent a letter to 151 Quebec writers and artists to determine if there was enough interest in creating an association separate from the C.A.A. Of the ninety responses received, eighty-eight were in favour of establishing an independent association. As a result, on 28 March 1936, the Société des écrivains canadiens was established, and the French section of the C.A.A. was officially disbanded on 19 May 1936. Because the French section was short lived, and because the literary field in Quebec was very different from the rest of Canada at the time, this dissertation focuses exclusively on English Canada. ${ }^{6}$

\section{The C.A.A.'s Legacy}

Almost from the beginning, the C.A.A. was criticized for its perceived conservative politics, traditional literary preferences, and controversial methods of promotion, earning itself "the reputation of traditionalism, conservatism, and parochialism, clinging to the outdated, colonial poetics of Victorian sensibilities" (Breitbach 154-5). These criticisms have had a surprisingly strong impact on the legacy of the C.A.A. By far its most enduring legacy is F.R. Scott's satirical poem "The Canadian Authors Meet," first published in April 1927 in the McGill Fortnightly Review. As John Lennox notes, Scott's attack on the C.A.A. has become "the best known depiction of the Canadian Authors Association [because the] belligerent tone of its satire and the vintage of its years has given it the aura of definitive authority" (94).

\footnotetext{
${ }^{6}$ Josée Vincent has written a number of articles on the history of author associations in Quebec. For further reading in this area, see "Faire voir pour faire (re)connaitre: le travail de promotion de la Société des écrivains canadiens, de 1936 à 1960" and "Les professionnels du livre à la conquête de leur marché: les associations professionnelles dans le champ littéraire au Québec."
} 
Many of the stereotypes now associated with the association can be traced to Scott's poem, such as its apparent "Victorian sensibilities" and its "zeal for God and King"; its outdated appreciation of the Confederation poets; the gendered aspect of the association, composed of "Virgins of sixty who still write of passion"; and its naïve patriotism, in which a day cannot go by without "new authors springing / To paint the native maple." While the poem has been read as a general satire of the Canadian literary scene of the 1920s, in which Scott saw a continued admiration for the Victorian poets and a rejection of the modernists, there are a number of direct references to the C.A.A. that have lost their cultural significance over time. Most notably, the fifth stanza invokes a couple of direct references to the C.A.A.:

Shall we go round the mulberry bush, or shall

We gather at the river, or shall we

Appoint a Poet Laureate this fall,

Or shall we have another cup of tea?

Commentators on the poem occasionally note that the appointing of a Poet Laureate stands out in comparison to the telling of nursery rhymes, praying, or drinking tea, and suggest that its inclusion is meant to satirize these authors, who perform any activity with the same air of seriousness and urgency. ${ }^{7}$ The mention of appointing a Poet Laureate, however, is a reference to one of the C.A.A.'s first acts as an association-of appointing Bliss Carman as Canada's Poet Laureate (an act that was heavily criticized). Similarly, the reference to having another cup of tea is most likely a reference to the 1926 annual

\footnotetext{
${ }^{7}$ For example, see Vautour and Verduyn (336). It is worth noting that Vautour and Verduyn make a compelling, and original, argument that Scott's poem and critique is aimed at "poetic inaction just as much as at actual individuals" (335). In other words, Scott is offended by the fact the members of the C.A.A. spend more time talking about literature than actually producing it.
} 
C.A.A. convention, where an afternoon of discussions "on the basic business of authorship was simply scrapped in order to give the delegates more leisure to prepare for a tea-party" (Kirkconnell, Slice 293). Both of these moments from the C.A.A.'s history exemplify what Scott found so disdainful about the association.

Although Scott's satirical critique of the C.A.A. is the most well known, it was not the only one. For example, the final issue of the Canadian Mercury, the Montreal Group's magazine after the McGill Fortnightly, contains the anonymously written satirical poem "God Bless the C.A.A.!" Each stanza in the poem repeats a variation on the same critique, that the association allowed anyone to join, even amateur and "nonprofessional" authors:

Rosie wrote some little rhymes

For the Birdseye Centre Times:

Gushing friends did then exclaim:

"This will surely bring you fame!

You must join the C.A.A."

Clementina penned a story

Pointing youth the way to glory,

So was honored with a party

By her fellow-literati

Who had joined the C.A.A.

Hiram gained by two reviews 
In the Pleasant Valley News

Local fame and in addition

Realized his life's ambition:

He has joined the C.A.A.

Reverend Percy wrote a play

For the local Y.P.A.,

Thus received an invitation

To deliver an oration

To the local C.A.A.

As a writer, poor Maria

Yearns to set the world on fire;

Though her works remain unborn,

She is not one whit forlorn:

She has joined the C.A.A.

Alongside ridiculing the C.A.A. for its open membership, and the fact that it attracted apparently amateur writers, this poem also suggests that the C.A.A. recruited and supported writers of middlebrow literature. This aspect of the C.A.A. drew heavy criticism from the association's critics in the first few decades of its existence.

The first satirical representation of the association was published less than a year after it was formed. H. F. Gadsby, president of the Parliamentary Press Gallery in the early twenties, wrote a mock scene set at the C.A.A.'s second annual convention for the 
Montreal Standard. This scene opens with a number of C.A.A. members arguing over the connection between the quality of literature and financial success. Pelham Edgar acts as the purist, denouncing "Lucre! Filthy lucre! It is the bane of our brotherhood" and argues that "Starvation in a garret is the proper training for great writers" (17). Onota Watanna (Winnifred Eaton) and Robert Stead act as advocates of proper financial renumeration for authors, with Watanna explaining: "Then came success. I wrote a best seller. Moneymoney—money! It was beautiful—so much better than poverty and the garret!" Stead, in turn, argues that "A new school has arisen which says that the laborer is worthy of his hire. We refuse to starve" (17). Gadsby's rendering of the debate of an author's relation to the marketplace mocks and belittles both sides, suggesting that a stringent appeal to the notion that "literature is not literature until it has been dead at least fifty years" and the idea that authors automatically deserve financial success are equally foolish.

Gadsby's scene ends with the C.A.A. President, Murray Gibbon, arguing that Government patronage for authors is long overdue, and thus invites suggestions from fellow C.A.A. members as to what this patronage should look like. For Gadsby, this notion of government patronage is farfetched, and he includes the following ironic suggestions: punishment for proofreaders who add mistakes to a work, with jail time for a third offence, and the suggestion that the Government make "O Canada" the National anthem, and offer a prize of $\$ 10,000$ for the best English lyrics to it. Alongside these ridiculous suggestions, however, Gadsby offers recommendations that the C.A.A. actually made and took seriously: that authors should receive equal rights as other labourers ("We are producers, manufacturers — what you like. We demand our share of the common blessing of protection. If the farmers can get it why not the poets, the 
novelists, the short story writers?") and the notion that the government might offer a literary prize for the best works of fiction. For Gadsby, presumably all of these suggestions are to be equally ridiculed, as they are presented in the same mocking manner. The article concludes with the final suggestion:

What we authors need is readers and to that end I move that the law of Canada make it compulsory to read our books, each and every one of them immediately or within a month of their issue! ... I would further move ... that persons who fail to read our books within the period prescribed be sent to jail and kept there until they have read all our output up to date. (17)

While intended as satire, it is surprising how closely the dialogue in Gadsby's mock scene matches actual debates the C.A.A. would find itself in, especially in the 1940s and 1950s, around government patronage.

Taken together, these three satirical depictions present the C.A.A. as an association of amateur writers, mostly women, who are overly patriotic, with outdated literary tastes, and who spend more time worrying about money than they do about creating good literature. For these satires to function successfully, however, these qualities of the C.A.A. need to have been generally accepted as being worthy of mockery. And as the success of Scott's poem shows, the prevailing view of Canadian literature in the postwar period did find these notions to be worthy. During the first half of the twentieth century, however, this depiction of the C.A.A. might not have brought the same level of contempt. It is worth remembering that Scott's poem originally concluded with the following stanza:

Far in a corner sits (though none would know it) 
The very picture of disconsolation,

A rather lewd and most ungodly poet

Writing these verses, for his soul's salvation.

This final stanza was dropped when the poem was printed next, but it shows that at its writing, in 1927, Scott felt that his opinion of the C.A.A., and his distaste of their relationship to the literary field, was not widely held. Instead, he was the ignored poet sitting in the corner voicing his discontent. This dissertation seeks to reposition these critiques of the C.A.A. in their historical moment. Instead of simply agreeing with these portrayals, it attempts to position and understand the C.A.A.'s conception of the literary field, one in which all authors, and all literature, were worthy of support.

This project is not the first to reconsider the legacy of the C.A.A. The first serious attempt was John Lennox’s 1981 article "New Eras: B. K. Sandwell and the Canadian Authors' Association, 1919-1922." In this article, Lennox explains that after examining William Arthur Deacon's archives_-Deacon was a prominent member of the C.A.A.- - he came to appreciate "Deacon's and many others' tough-minded commitment to their Association, concern for the well-being and encouragement of younger writers, and dedication to fostering the writing of their time and place" (94). As a result, his article, which examines B. K. Sandwell's role in the early development of the C.A.A., begins the project of re-examining the "description of the C.A.A. provided by Scott and Gadsby" (94). More recently, Clarence Karr has fiercely decried the current legacy of the C.A.A.: It has been fashionable until recently for critics such as Frank Scott, from an arrogant, modernist perspective, to condemn the Canadian Authors Association as a group of self-congratulatory amateurs who eschewed standards and cared only 
about the commercial aspects of literary existence. Such criticism displays contemptible, condescending elitism and ignores the fundamental role which the association played in its early decades. (Authors 200)

This project, in part, aims to rectify this problem by exploring this "fundamental role" that the C.A.A. played. Alongside these scholars who argue for the need to reexamine the legacy of the C.A.A., there are also some scholars who note how powerful the modernist narrative of the C.A.A. has been. J.A. Weingarten, for example, in writing about modernist poetry in Canada, has noted:

the movements and institutions for which modernists wished to be gravediggers were actually contemporaries with Canadian modernism. Discourses on Canadian literature have tended to downplay this fact by stressing modernists' hostility toward the "old" Romantics and Victorians. That particular interpretation of the era is a skewed one.... Organizations like the Canadian Authors Association (est. 1921) promoted and financially backed writers that were generally conventional, yet they established themselves at almost the exact same time as the young modernist groups that lambasted them. (emphasis in original, 315)

This dissertation supports Weingarten's assessment, and aims to show how this consistent interpretation of the 1920-1960s in Canadian literature is "skewed," particularly in relationship to the development of Canadian authorship.

Alongside these scholars' reconsiderations of the C.A.A.'s legacy, there is a larger group of scholarship that reconsiders the canonical narrative of modernism in Canada, often critiquing or questioning its masculinism and elitism. Carole Gerson, for example, has shown that between 1918 and the 1940s, "the canon of English-language 
Canadian literature was ... governed less by cultural consensus than by the whims and agendas of certain individuals in positions of power" ("The Canon" 47). Gerson notes that these individuals in power were men, both nationalists and modernists, who "formed a loose 'invisible college' distinctly masculine in gender and taste" (47), which successfully prevented women authors from being canonized. Gerson's work, more broadly, can be seen as an attempt to overturn the work done by this invisible college of men, and other scholars have followed her lead. For example, in her introduction to Wider Boundaries of Daring, Di Brandt notes how modernist women authors were excluded from the literary canon, often as the result of the action of their fellow male modernist writers, and that Wider Boundaries of Daring "offers a corrective to the current telling of Canada's literary history" (8) by highlighting the contributions made to modernism by women writers. Similarly, Dean Irvine has continued this work by examining the large number of women involved in little magazines in Canada, who have "remained peripheral to the historical narratives" (3) largely because of the "typically masculinist character of the little magazine" (5). Candida Rifkind's work on Canadian women authors' participation in the literary left during the Great Depression, Comrades and Critics, also responds to the revisionary modernism that Brandt is calling for, by focusing specific attention on the gender issues often obscured by modernist narratives. Rifkind's work on the poetry of Edna Jacques is a similar reclamation project, aiming to explain why one of Canada's best-known poets has all but disappeared from cultural memory. In examining how the borders of "Canadian modernist literary studies ... have been policed" ("Too Close" 93), Rifkind argues convincingly that Jacques's work not only threatened the literary establishment's view of highbrow literature by being 
sentimental, and thus feminine, but that her "prolific output and her market success frustrated high cultural attempts to develop a modernist English-Canadian literature" (93). In other words, not only was her work sentimental, it was dangerously middlebrow, at least in the minds of the literary elite. These various scholars, and their work, have created a foundation that allows for, and encourages, further scholarship — such as this dissertation - that challenges, and perhaps dismantles, the modernist narrative of the development of Canadian literature.

This dissertation also builds on scholarly work that seeks to reexamine literature in the first half of the twentieth century by focusing on what is often excluded - namely, the middlebrow. In her discussion of the rise of the American Book-of-the-Month Club in the first half of the twentieth century, Janice Radway argues that the Club was successful "because it insistently applied to the business of book production and distribution marketing principles and advertising practices generally associated with other industries" (128). In other words, the Club took as a base assumption that the book industry was no different than any other industry, and began treating books like commodities. This was a drastic change, Radway argues, to the book production industry, which clung to "its continuing ideological, if not economic, dependence on a different model of production organized around the creative activity of a singular, autonomous author" (128). Heather Murray has called this encounter, "in which the 'high art' values of literary singularity come into a contradictory encounter with new and expanded systems of production and distribution" (177)—or where “"modernism,' and modern commodification, meet" (177) - "middlebrow modernism" (177) because it "necessitate[ed] the christening of a new category, the middlebrow" (Radway 128). Middlebrow projects, such as the Book- 
of-the-Month Club, proved "surprisingly controversial—notorious even” (128), Radway argues, because they "posed a significant threat to the essential concepts and forms structuring the bourgeois literary realm, including those defining the book, the author, the reader, and the proper relations among them" (128). These middlebrow projects that insisted on the commercial aspects of the book industry were often resisted, and have often been ignored in modernist-focused literary histories. The resistance was caused by "the scandal of the middlebrow:" the "failure" of the middlebrow "to maintain the fences cordoning off culture from commerce, the sacred from the profane, and the low from the high" (Radway 153). Scholars, like Radway, Murray, and Rifkind, argue that it is because of this resistance and what it reveals about the prevailing conceptions of the literary field that these projects are worthy of study.

This dissertation engages with many of these concepts, specifically in relation to the C.A.A.: the middlebrow, feminized sentimentality, and overt commercialism. And while the association has been labeled, and criticized, for endorsing these anti-modernist views, this dissertation shows that these labels were not always accurate descriptions of the C.A.A. Although often yoked together to describe the association, the C.A.A. spent the first forty years of its existence negotiating a constantly changing literary field, and its positions in that field adapted and evolved, and were at times even contradictory. The yoking together of these concepts, especially in an effort to label the C.A.A., can be seen as an easy way for the modernists to differentiate themselves from the association. As Candida Rifkind notes, "If the young men of English-Canadian modernism imagined themselves as the new age, as both the present and the future of Canadian literature, then their modernism needed its foil in the anti-modernism of the figure of the Victorian 
poetess and her anachronistic ideals" (Comrades 10). This effort to create a foil belies the fact that differences between the two groups were not as stark as the modernists wanted to believe.

\section{Membership}

In his description of the initial meeting of the C.A.A., Arthur Stringer refers to the group of gathered writers as "a sort of union of the ink-pot" (24) This description is apt. Not only did the creation of the C.A.A. bring writers from across the country together into a single association with a shared goal, but the result of this "union" was the establishment of a trade-"union." As Stringer notes, the writers gathered at the inaugural meeting were there "to get unionized . . . after the manner of the plumber and the locomotive-engineer" (24). The C.A.A. referred to itself, at various times, as both a "union" and a "crafts guild." At the inaugural meeting of the C.A.A., B.K. Sandwell made the explicit connection between the association and professionalism:

Canadian authorship was now emerging from the amateur to the professional stage, and he [Sandwell] believed it to be highly important that that change should be accompanied by an organized expression of the professional interests of the followers of the art of letters. . . he believed that it was desirable, both for material and spiritual reasons, for Canadian authors to form an association, a trade organization if they wished to call it so. (qtd. in "The Convention" 8-9)

While the C.A.A. occasionally spoke of professionalism, or of improving the profession of authorship, it is difficult to pin down exactly what authors like Sandwell imagined 
when they used these terms. Scholars of authorship studies rarely agree on whether or not authors belong to a profession. Pierre Bourdieu, for example, remarks that "The 'profession' of writer or artist is one of the least professionalized there is, despite all the efforts of 'writers' associations', 'Pen Clubs', etc” (Bourdieu, Field 43).

In reference to the rise of American authorship, James L. W. West III argues that authors "have been neither true professionals nor true tradesmen, and as a consequence they have found it difficult to combine for business purposes or even for the creation of collective identity. They have been neither professionals nor proletarians: they have instead occupied an anomalous and uneasy economic position in American society" (7). West's argument rests on a definition of a "true profession" which has necessary characteristics: candidates must be trained before they can gain entry to the profession, often through apprenticeships; they often have to pass examinations, and are then licensed; they join associations with written codes of ethics; and they often have specialized knowledge (8). As a result, West argues that "Authorship in America has not been a profession during [the twentieth] century, nor has it been a trade. It has been more nearly a craft, a cottage industry. ... In cold economic terms . . . authors have been common laborers" (20). By contrast, William Charvat argues that American authorship was professionalized during the twentieth century. To make his argument, Charvat does not rely on a definition of a "true profession," but offers his own definition of professional writing: "that it provides a living for the author, like any other job; that it is a main and prolonged, rather than intermittent or sporadic, resource for the writer; that it is produced with the hope of extended sale in the open market, like any article of commerce; and that it is written with reference to buyers' taste and reading habits" (3). In 
this definition, professional authorship is reliant on an author earning a living by producing a commodity, available for sale in the open market, that is meant to be consumed and read. It is clear that the C.A.A. had this latter definition in mind when advocating for a profession of authors.

In the Canadian context, it would be many years before Sandwell's dream of Canadian authorship "emerging from the amateur to the professional stage" became a reality. In her monograph, Making Culture, Maria Tippett describes the various cultural organizations that existed in Canada in the first decades of the twentieth century. The role of amateurs in these cultural organizations, and in the development of cultural activity in Canada, was complicated. As Tippett argues:

The belief that cultural activity existed "for its own sake rather than for commercial purposes," that it was to be done in one's leisure time, and that an indigenous culture could be fostered by the amateur did much, of course, to exalt the amateur's role. But at the same time such assumptions seriously diminished the place available for those to whom writing, acting, playing musical instruments, painting and directing, and composing were chosen vocations and a means of livelihood. (16)

While amateur cultural activity was proving to be successful, the idea that art should remain outside of commerce had the potential to hurt artists who strove to become "professional." And, as Tippett notes, "Many amateur groups ... did nonetheless aspire to professional status" (15). Eventually, these amateurs "were pushed towards forming professional organizations, so that they might be seen, patronized, and above all, respected as the true markers of the country's artistic culture" (17). Tippet argues that a 
professional organization can be distinguished from a club of amateurs by its motivations: a professional cultural organization "attempted to place their activity on a professional footing: by integrating it into the marketplace, by lobbying the government for various forms of assistance, and by consciously trying to develop what they perceived to be a national culture" (17). The C.A.A., then, can be understood as a professional organization, according to Tippet's terms, that attempted to fulfill Sandwell's goal of taking Canadian authorship from the amateur to the professional.

An important part of this goal was that the C.A.A. wanted to improve the state of authorship in Canada for all writers, not simply members of the association. This is made clear in the C.A.A.'s various initiatives, such as lobbying the government for copyright change, which would benefit all Canadian writers. The C.A.A. was explicit in this intention. For example, in 1931, in response to a letter from Leslie MacFarlane complaining about the C.A.A., William Arthur Deacon noted:

As I said, you reap the benefits whether you help or not. Why not at least pay your little fee and lend your name, for whatever it's worth, to help those who are struggling to get you better working conditions as truly as the English trade unions of last century took the laborer out of direct slavery and gave him some degree of economic power-through union. (Deacon qtd. in Lennox 94-5) The belief that all Canadian writers were worthy of support, proper pay for their labour/writing, and all equally worthy to be considered an "author"—-regardless of gender, class, quality of their writing, the genre of their literary output, et cetera-is fundamental to understanding the C.A.A.'s conception of authorship. 
Although the association consistently argued with critics who insisted on establishing hierarchies of authorship, its membership structure itself relied on such a hierarchy. The association occasionally attempted to explain the hierarchy found within its membership as the result of a desire for inclusivity. As Duncan Campbell Scott explains:

An organization of anything like adequate strength [to protect the rights of authors], composed of professional writers alone, is here and now impossible. Our founders accordingly decided . . . to impose no arbitrary or narrow standard of the 'recognized position' which would qualify a writer for regular membership, and to welcome as non-voting or associate members those who had a keen enough interest in our objects to come in and increase our strength. (4) According to this conception of its membership, authors were imagined to be "full members," while other members of the book trade, such as booksellers and publishers, who had a vested interest in the state of Canadian authorship could join as an associate member. In reality, however, this was not how the two types of memberships were filled.

While the association was originally aimed at authors, or "creators of copyrightable literary material," it quickly allowed other creators of copyrightable material to join, such as musicians, especially when they were also fighting for copyright protection. As explained in the constitution, there were specific requirements for joining the association:

The membership shall comprise three classes, viz. :1.--Regular members. 2.-Associate members. 
3.-Life members.

Any writer, dramatist or scenario writer, or other creator of copyrightable literary material of recognized position in his or her profession as author may be admitted at the discretion of the Executive Committee as a regular member.

Other writers, publishers, booksellers, etc., who may have sympathy with the objects of the Association, but who are not considered by the Executive Committee as qualified for full membership, may be admitted, at the discretion of the Executive Committee, as Associate members, who shall receive the published reports of the Association and have the privilege of attending its General Meetings, but shall not have a vote.

The Council may appoint a Membership Committee, the duties of which shall be to investigate the qualifications of applicants and to report upon the same to the Executive Committee. ("Provisional" Article 3, 4)

The difference between the two types of membership was incredibly subjective, made more difficult by the fact that the various roles within the literary field were not rigidly defined. A regular member was a writer "of recognized position in his or her profession as author." It is not clear, however, how this recognition was to be calculated. An associate member, on the other hand, was any member of the book trade, including writers "who are not considered by the Executive Committee as qualified for full membership." As a result, the position of a writer as either a "Regular Member" (and by extension openly acknowledged as "recognized" and a member of the "profession") or an "Associate Member" (and by extension, being excluded from these categories) was dependent on the subjective decision of the Executive Committee. 
There is some anecdotal evidence to support the idea that a Membership

Committee actually evaluated individual membership applications. Robert Allison Hood, for example, reflects:

Throughout Canada there were many applications to join and there was a certain amount of sneering at the rather slight pretensions to authorship put forward by some of those aspiring to election. It was said that in the East a chef of one of the larger hotels had sent in his application on the ground that although his profession did not deal much with words, yet in the preparation of Noodle Soup he had a great deal to do with letters. (5)

Reading through the membership applications found within the C.A.A.'s archives, ${ }^{8}$ however, it is difficult to assert how rigourously applications were vetted, as the applications often lack the C.A.A.'s responses to them.

This division within the membership of the C.A.A. is rarely discussed by scholars, although it was clearly an important aspect of the association, both internally and externally. Some members felt that a division based on "professionalism" in an association that wanted to improve the working conditions of all Canadian writers was unfair. For example, in 1944 an unnamed member of the association wrote a letter outlining this complaint:

\footnotetext{
${ }^{8}$ The C.A.A.'s archives are stored at Library and Archives Canada (Canadian Authors Association Fonds MG28-I2). However the C.A.A. did not attempt to make serious efforts to archive its material until the late 1980s. At this point, it attempted to consolidate its archives, and retrieve material that had been deposited at various repositories across Canada. In 1998 the C.A.A. deposited its archives at the LAC, although it had not been successful in consolidating all of its archives. As a result, there are various smaller archives, usually of specific local branches, spread across the country. As well, since the association was late in attempting to collect its archives, there are very few records from the early years of the association. As a result, in this dissertation, I have relied on other archival fonds, especially personal archives of prominent C.A.A. members.
} 
I don't think it is fair to ask young, unestablished writers to pay a five dollar fee and not be taken in as an 'Ordinary Member.' They are not given a vote and are not even an 'Ordinary Member,' and yet they are expected to pay as much as the established writers.... It suggests a caste to me. If it is the purpose of the CAA to keep a closed little group fo [sic] professional writers together and the rest on the outside, then it has the right policy. But if it is working in the best interest of Canadian writing, then there is room for improvement. ("Provocative Criticism"

Despite this well-founded argument, some of the more elite members of the association were discouraged by the quality of the associate members. Watson Kirkconnell, for example, stated: "the weight of barnacles has sometimes threatened to sink the ship. In other words, far too many have joined on the strength of a single chapbook or a couple of magazine articles" (Slice 302). This attitude, however, appears to have been the exception, with other members of the National Executive actively recruiting young and amateur writers. It is worth noting that Kirkconnell's criticism, written in the late 1960s, was partly driven by the result of allowing amateur writers into the association, which "helped to blacken its image in the public eye," as it "made us sitting ducks for young scoffers with a catapult" (302). The association was often criticized for the belief that it supported amateur and "poor" literature in favour of highbrow culture.

Public attacks against the C.A.A. for the number of amateur writers in its membership occurred throughout its history, but perhaps one of the most public debates took place in the wake of the 1931 annual convention. Leslie McFarlane ${ }^{9}$ wrote a letter to

\footnotetext{
${ }^{9}$ Leslie McFarlane was a journalist and novelist and wrote most of the early novels in the successful Hardy Boys series under the pseudonym Franklin W Dixon. In 1932, at the time of this public debate, the first
} 
the editor of the Mail \& Empire about the large number of amateur writers in the C.A.A. suggesting "If, before the convention, the Canadian Authors' Association had suddenly rid its ranks of all those members who are not authors, never have been authors and never will be authors, the convention could have been staged in any hotel bathroom, and no one would have had to sit in the tub" (6). This comment spurred further letters to the editor on the topic, both supporting and disagreeing with McFarlane's statement, resulting in a month long public debate. B. K. Sandwell, for example, wrote to defend the associate members, arguing that although they are not professional authors, "they are sufficiently interested in advancing the cause of authorship [to pay a membership fee] per annum to an association which exists chiefly to defend the interests of authors in legislation and litigation" ("Canadian Authors" 6). William Arthur Deacon attacked McFarlane, arguing that all Canadian authors of note were members of the C.A.A "except a handful—mostly young whipper-snappers like you who jeer while we do your work for you," and suggesting that McFarlane's attack does "others an injustice as well as himself" ("Leslie" 8). Others, however, came to McFarlane's defense. Louis Arthur Cunningham, for example, agreed with McFarlane, noting that "the membership list of the C.A.A. is a laughable proclamation of the childish vanity of mankind" (6).

This well-published view of the C.A.A. as being composed mostly of amateur writers continues to haunt the association today, though some members of the C.A.A. did attempt to restrict membership. In 1932, for example, the Membership Committee of the Toronto Branch wrote a report arguing for the need to amend the associate membership clause. The report notes the C.A.A. "bid fair to become overloaded with persons, who 
however interesting and delightful, are distinctly in the class of amateurs or else are persons who may at one time have been authors but who, have not written a word for an uncounted number of years" before enquiring, "Is this a desirable object?" (Perry). The report concludes that if the C.A.A. wishes "to be a club with professional standing, the clause dealing with Associate Membership ought to be tightened up considerably" (Perry).

Although the national executive did not tighten the rules on membership, the Toronto Branch still oversaw membership applications to its branch, and for a number of years at least, established a very clear hierarchy for membership. In the Toronto Branch in the early 1930s, full membership was exclusively reserved for "working authors," meaning an author had to have been paid for her or his writing. Associate membership was reserved for authors writing "merely fugitive verse" (Chairman of Membership Committee, Letter to Grace E. Budd). The Membership Committee took its role seriously, and refused even associate membership to a number of applicants. For example, in February 1933, Mabel Lechford, a costume designer, applied for associate membership. In response to the application, Donald G. French wrote to the Membership Committee,

It is not apparent that the lady, however estimable she may be, has the necessary attainments to allow her admission to this organization. The requirements have been interpreted very broadly in the past, but if the qualifications mentioned would entitle one to membership, I could see no reason for refusing membership to the state electrician. One of the members of our Executive comments that the 
next thing we may expect is that somebody will apply for membership on the ground of having made a suit of clothes for an author. (Letter to Anne Perry) In these years, the Toronto Branch had a clear goal—ridding the C.A.A. of its connection with amateurs and solidifying it as a professional association. Although the archives of the C.A.A. at Library and Archives Canada contain hundreds of membership applications, very few of the applications are from pre-1950, and even fewer have the association's response to the application. As a result, it is impossible to determine how the wider C.A.A. and its various branches oversaw membership applications, and whether the attitude of the Toronto Branch was widespread or not. ${ }^{10}$

Although the hierarchy of the membership system of the C.A.A. was meant to define profession (author/non-author) and professionalism (successful author/amateur author), the system ended up producing a gendered hierarchy. Carole Gerson and MariePier Luneau argue that "In the interwar period, women dominated the membership of the CAA, rising from 45 per cent of the more than 800 English-speaking members in 1924, to 58 per cent by 1933 " (95). While the per cent of women in the C.A.A.'s overall membership did steadily increase during the 1920 s, they may not have been as dominant as these critics suggest. In 1924, women represented 43.4 per cent of the total membership, in 1927, 49.2 per cent, in 1930, 54.2 per cent, and in 1933, 56 per cent. ${ }^{11}$ As

\footnotetext{
${ }^{10}$ From the material that is available in the archives, it appears that the membership guidelines were subjective, and varied over time. For example, in 1974, Miss I. M. Grierson applied for association membership, and under her qualifications simply wrote: "Nil (sigh!)." Her application was accepted (Grierson).

${ }^{11}$ I acknowledge that my figures are slightly lower than Gerson and Luneau's. I calculated my figures by counting the name of members, as published in the membership lists printed in the C.A.A.'s official publications. My calculations of female members are a little low, because the names on the membership lists are often reported by surname and initials only. As a result, identifying the female members was done through gender-specific titles: Mrs., Miss, Lady, and Mme, as well as by the occasionally given name, if it was provided. This method, unfortunately, cannot account for female members who are identified by
} 
Table 2 shows, this change to the membership was due both to a steady increase in the number of women members joining the C.A.A. (after an overall decrease of membership between 1924 to 1927), as well as a corresponding almost negligible increase in the number of male members joining the association during the same time period.

Unfortunately the C.A.A. stopped publishing membership lists in 1933, meaning that data on the gender division in the C.A.A. past this year is not available. If the general trend of the 1920 s and early 1930 s continued, however, it makes sense that the percentage of women members in the C.A.A. would continue to increase.

gender-neutral titles such as Judge, Dr., Rev., Prof., or Hon. This might explain the slight variation in my figures and Gerson and Luneau's. 


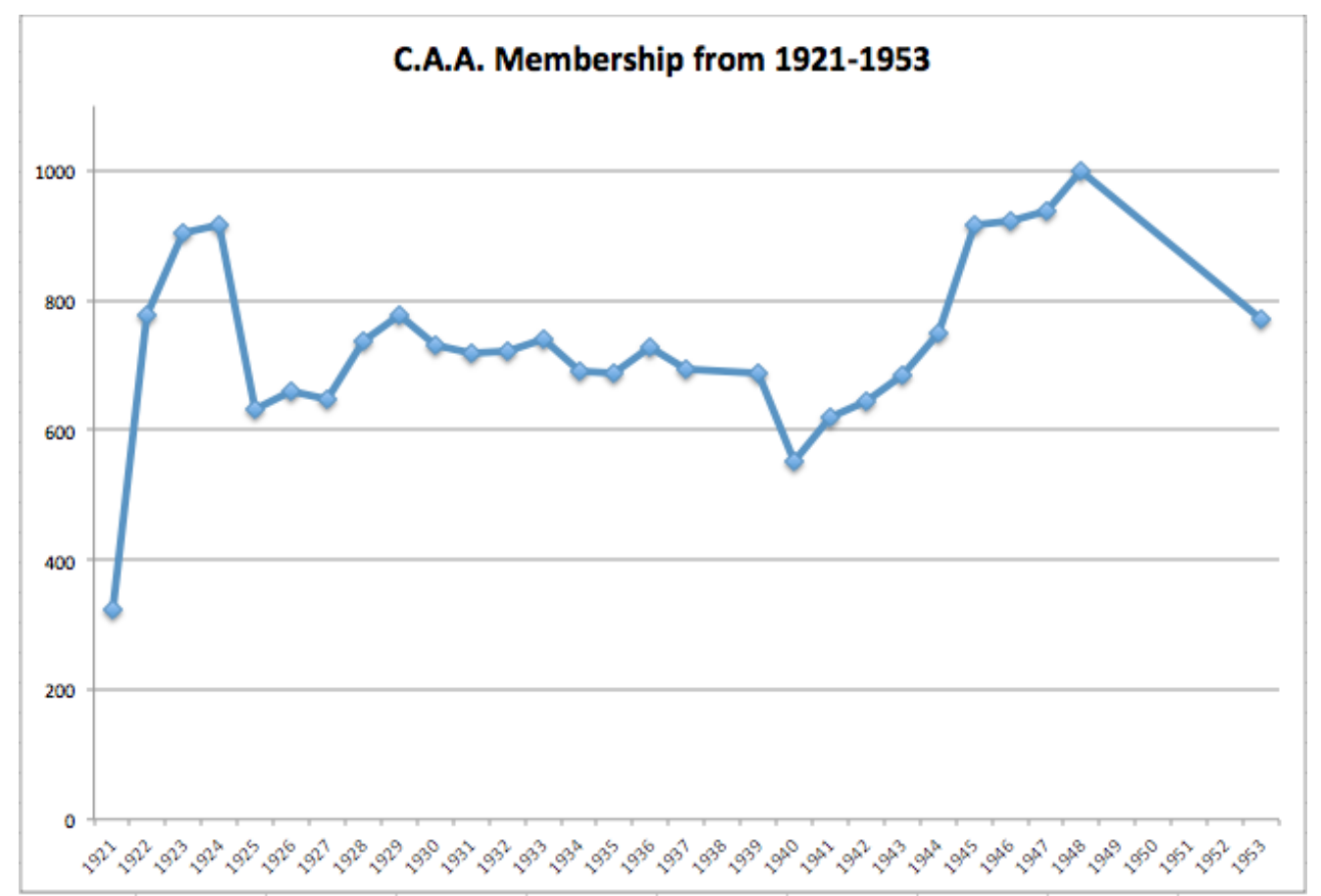

Table 1: Overall Membership of the C.A.A. $(1921-1953)^{12}$

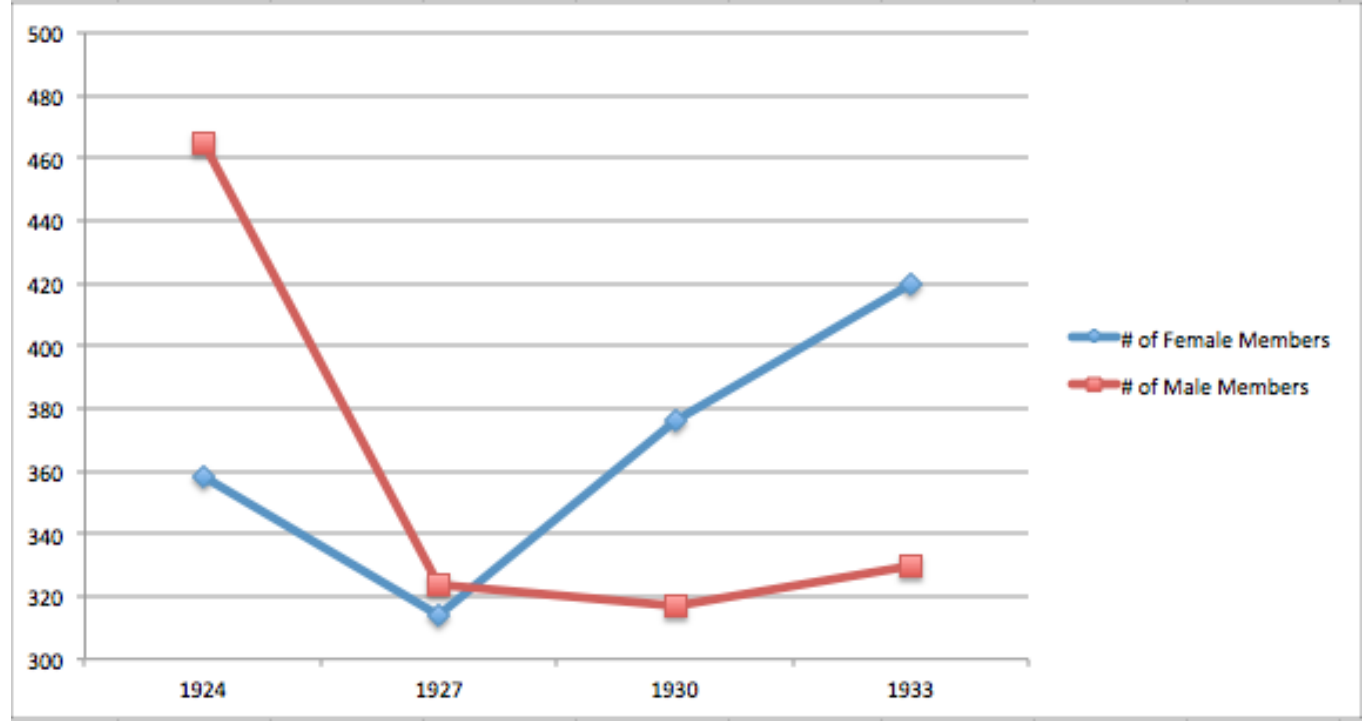

Table 2: Membership of the C.A.A. by Gender ${ }^{13}$

\footnotetext{
${ }^{12}$ This data is taken from the C.A.A.'s various official publications. This data was usually published in the Secretary's Report from the proceedings of the annual conventions. There is no data from 1938 as the National Secretary died unexpectedly, and the data was not presented at the annual convention. After 1948, the yearly membership was no longer reported on a yearly basis, which is why there is no data for the years 1949-1952, inclusively.

The membership includes all three categories of members: regular, associate and life. These figures do not, however, include members in the French Section.
} 
More revealing than the gender division in the overall membership of the C.A.A. is the gender division within the two categories of membership: regular members and associate members. As Table 3 shows, while the percentage of women in the regular membership grew steadily in the 1920s, until they reached fifty per cent of the regular membership in 1930, the percentage of women in the associate membership is far less equal. In 1924, women represented almost half of the Associate Members, in 1930, they represented two-thirds of the Associate Members, and by 1933, they represented almost three-quarters of the Associate Members. This suggests that the difference between Regular Membership and Associate Membership was, in reality, a division based primarily on gender. Unfortunately, because of the lack of archival records, it is not possible to determine if this is a result of self-selection (i.e. women authors were more likely to view their work as only worthy of associate membership status) or if it was institutionalized sexism. It may very well be a combination of these factors.

\begin{tabular}{|l|c|c|}
\hline & $\begin{array}{c}\text { Per cent of women in } \\
\text { Regular Membership }\end{array}$ & $\begin{array}{c}\text { Per cent of women in } \\
\text { Associate Membership }\end{array}$ \\
\hline $\mathbf{1 9 2 4}$ & 35.3 & 46.4 \\
\hline $\mathbf{1 9 2 7}$ & 44.8 & 60.0 \\
\hline $\mathbf{1 9 3 0}$ & 50.0 & 67.2 \\
\hline $\mathbf{1 9 3 3}$ & 49.1 & 73.7 \\
\hline
\end{tabular}

Table 3: Per cent of Women in Regular and Associate Membership from 1924-1933

\footnotetext{
${ }^{13}$ Membership lists are from the following sources: Canadian Bookman 6.5 (1924): 120-22 and Canadian Bookman 6.6 (1924): 146-47, Author's Bulletin 5.1 (1927): 42-55, Author's Bulletin 7.1 (1929): 27-35, and Canadian Author 11.2 (1933): 16-23.
} 
Of all the critiques leveled against the C.A.A., the most disparaging was the criticism and ridicule that it was an association composed predominantly of women writers. Like most of the stereotypes of the association, this critique was most famously memorialized in F.R. Scott's poem "The Canadian Authors Meet," where he depicts this group of authors as "Virgins of sixty who still write of passion" who are led by a "Miss Crotchet." As Di Brandt observes, Scott's poem "is often cited as the birth announcement of Canadian modernism; one can read in it a subtext of masculinist self-birthing ... through the rejection of maternity and women's collegial presence and influence" (3). This rejection of women writers, and their presence in the literary field, was not just operating in the "invisible college" of men, to borrow Carole Gerson's term, but appears to have also been more widely accepted at the time. Wallace Reyburn, in an article in the National Home Monthly in 1950, suggests: "The average Canadian has formed in his mind a pretty clear picture of what the Canadian Authors Association consists of. To him it is a bunch of old women — of both sexes—who hold literary teas and write poems about Our Heritage, The Flag, and Spring Comes to Unionville" (12). Reyburn then presents a series of sexist and insulting anecdotes about women authors, before concluding that "Such old biddies would seem to be the very backbone of the Association" (12).

This gendered legacy of the C.A.A. has had a considerable impact on the history of the association and on Canadian literary histories more generally. As Brandt notes, Scott's poem "is a narrative of origins that has been obediently adhered to by most Canadian literary historians into the present, even though it is ... [a poem] that effectively dismissed the growing influence of women writers in the Canadian literary scene at the time" (3). Despite the strength of the belief that the C.A.A. was 
predominantly composed of amateur women writers, the situation was much more complicated. Although it did have slightly more women members, the association was continually run by men, some of whom fought against female leadership. Carole Gerson, for example, points to an example of this "gendered subtext to Canadian literary politics" in Kathryn Colquhorn's description of Madge Macbeth's reception at a C.A.A.

convention. Macbeth went to Toronto to make a speech at the Annual C.A.A. dinner:

[Macbeth] had a pretty mean reception here ... Pratt was in the chair and he, and Prof. De Lury, spoke so long, that she didn't get a chance to say a word. A lot of people thought that it was a put up job, as Pratt had charge of things as chairman. Then, when she was elected National President, none of the Executive, Pratt, Deacon, or Edgar, attended the Convention. (Kathryn Colquhorn qtd. in Gerson “The Canon" 54)

Lucy Maud Montgomery received a similarly misogynist response when she was running for the executive of the Toronto Branch. Montgomery's biographer Mary Henley Rubio notes that "The Canadian Authors Association had been very important to Maud after [her] move to Toronto. The CAA was a lifeline, in fact, that pulled her out of her personal stress at home" (529). On April 8, 1938, however, at an election for a new executive, Montgomery was pushed out by Deacon. She writes in her journal: "The election of a new executive was held and I was elbowed out. It is not worthwhile going into details. Deacon had it all planned very astutely and things went exactly as he had foreseen. I at once withdrew my name from the list of candidates" (qtd. in Rubio 530). It is worth noting that in both of these cases, the author was not the stereotypical association member - they were both incredibly successful, and were by all definitions 
"professional" authors. If this is the treatment received by authors of their stature, one can only imagine the treatment accorded to amateur writers in the association.

Despite the misogyny that women authors faced both within and without the association, they continued to join, and in growing numbers, and this is an important aspect of the association's history. ${ }^{14}$ There are several reasons why women writers most likely continued to join the C.A.A. First, although the National Executive was predominantly run by men, a number of the local branches across the country were more welcoming. A number of these local branches had women in positions of power on their executive, including Branch President. And because of the structure of the C.A.A., with strong, and at times independent, local branches, it would have been possible that women writers did not experience much sexism in their daily encounters with the association, especially if they lived outside of Ontario. Secondly, and perhaps more importantly, women most likely continued to join the association because of its conception of authorship. Even if its membership was divided by professional ranking, the association consistently defended all working writers in all of its initiatives. In practical matters, the association consistently advised its members on how to get published in a wide array of venues, and in a wide range of genres, including "lowbrow" or pulp fiction. Advertising, accepting, and encouraging the writing of genre-fiction — which was predominantly written by women — was a rarity in a literary field that was beginning to form more rigid definitions of authorship.

\footnotetext{
${ }^{14}$ Susan Coultrap-McQuin identifies a similar paradox facing American women writers of the midnineteenth century. These women writers, like the women members of the C.A.A., "had a place in the literary world, yet that world often rendered them invisible" (7). Her work attempts to answer this paradox by exploring: "How can we explain women's persistence and success as writers in the face of attitudes and behaviors that could render them invisible? What ideas and social circumstances sustained their literary work in spite of the frequent devaluation of it?" (3). One of the reasons that she gives is important to remember in the Canadian context as well: "Collectively at least, and in many cases individually, women writers were important to the economics of the literary marketplace" (6).
} 


\section{Authors' Associations in England and the United States}

The debates around, and the changes to, authorship in Canada in the first half of the twentieth century parallel similar debates and changes in both England and the United States. The major difference in the development of authorship in Canada is that it took place almost a century later. Susan Williams notes that "By 1870 [in the United States], a book reviewer in a popular periodical could conclude . . that 'the writing of novels has become one of the regular professions"” (99). Similarly, Patrick Leary and Andrew Nash argue that in the last decade of the nineteenth century in England, "There was a growing sense that literature had become a profession" (194). Although the end of the nineteenth century saw "a gradual professionalization" among English-speaking writers in Canada, "enabling some to live from their work or at least derive a significant income from it, even if they had to emigrate to the United States or Britain in order to do so" (Cambron and Gerson 120), it would have been unlikely for Canadian critics, even by the 1960s, to agree that authors in Canada had achieved the status of professionals. ${ }^{15}$ Unquestionably the development of a class of professional authors in Canada was delayed by the fact that both the United States and England had fully developed national literary fields when Canada was still a colony.

Scholars agree that the profession of authorship in the United States can be traced back to the 1820s (Bell; Charvat), while English authors had begun to professionalize slightly earlier, between 1805 and 1820 (Charvat 29). Although a long process, it was at the beginning of the nineteenth century that changes in the literary field- "emerging innovations in the financing, manufacture, and marketing of books and periodicals" - that

\footnotetext{
${ }^{15}$ See Frank Davey's "Economics and the Writer."
} 
allowed authors to move beyond the concept of a writer as "the ideal of the gentlemanamateur" to the "actuality of the literary professional" (Bell 69-70). The professionalization of authorship, however, was slowed by the public's view of writing for profit. In America, especially, at the turn of the nineteenth century, writers conceived of authorship in "terms of British aristocratic tradition" (Charvat 6). This tradition, embedded in the British class system, insisted that a gentleman "never wrote for money, never put his name on what he wrote, and rarely even condescended to put what he wrote into print" (Charvrat 6; also see West 10). As a result, writers who wanted to earn a living by writing were seen as "betraying [literature's] true 'gentlemanly' nature" because they were selling their work "in the open market where it could be bought by 'the Vulgar"” reading public (Bell 74; Charvat 6). Even after this conception of authorship began to change in England, American authors clung to it (West 10). Another important reason that there was resistance to connecting literature with market success was that many authors in this time period "associated commercial success with feminization long before women novelists had much actual market success" (Bell 102). This view was prevalent in Canada, as Candida Rifkind shows in her study of the poet Edna Jacques, one of Canada's best-known poets who was excluded from the literary canon, largely due to her commercial success, particularly in the middlebrow genre of the sentimental. This distrust of commercial success, and its connections to both the middlebrow and the feminine, produced great anxiety in the literary field.

Authorship, as a profession, began to take hold in England and America when authors began to reject the disavowal of the marketplace as an essential component of literature. The rise of the professional author was contingent on "turning the literary work 
into a commodity" (Bell 73). As Charvat argues, "there were no professional authors until the success of the British writers proved that there was a kind of literature that everybody wanted to read" (Charvat 31). Bell notes that to suggest that "the basis of literature ... shifted from culture to commerce is perhaps to over-simplify" (73), but by the 1840s, market considerations had become an "inescapable component" of the profession. Similarly, Michel Foucault has noted that the figure of the "author" only existed after a "system of ownership for texts came into being," such as copyright laws, "at the end of the eighteenth and the beginning of the nineteenth century" (148). Foucault's attempt to define an "author" is different than my own, as his work is concerned "solely with the relationship between text and author" (141), whereas this project is concerned with the relationship between an author and the social, political, and economic world in which she lived. Nevertheless, some of his arguments are useful to recall. For example, Foucault argues that the "author" is not a predetermined concept, and that it differs from the "writer": "An anonymous text posted on a wall probably has a writer-but not an author" (148). The writer is simply someone that has written something; an "author," however, is a historically contingent category, linked to the institutions that define it. This defining is done through the "author function": the "result of a complex operation which constructs a certain rationale being that we call 'author.' . . . these aspects of an individual which we designate as making him an author are only a projection ... of the operations that we force texts to undergo, the connections that we make, the traits that we establish as pertinent, the continuities that we recognize, or the exclusions that we practice" (150). The debates around authorship in Canada during the first half of the twentieth century were concerned with the same issues: who gets to call 
themselves an "author" and who does not, who gets to determine what an "author" is, and which "authors" are worthy of government support.

Although Canada was almost a century behind England and the United States in developing a class of professional authors, the parallels between the development of authorship in these three countries are noteworthy. Susan Williams's description of the rise of authorship in the United States, for example, strongly parallels the same development in Canada (albeit eighty years later):

Between 1840 and 1880, many authors demonstrated a growing understanding of, and complex relation to, the literary market, seeking more protective copyright laws, more generous contracts, and greater earnings. They understood that relating to that market was not always a simple choice between resistance and collusion. Instead, they increasingly adopted authorial strategies that enabled them to succeed in the literary market on their own terms. Those strategies reflected the growing tensions between conceptions of author as genius and as chronicler of everyday reality. . . . By the 1880s, authorship was for many writers a rewarding occupation. (91)

As this dissertation argues, between 1920 and 1960, Canadian authors: engaged in debates regarding their relationship to the marketplace; lobbied the government for changes to the copyright act; attempted to intervene directly in the sales and promotions of their works; and debated the merits of highbrow, middlebrow, and lowbrow literature.

The rise of professional authors in all three countries share many similarities, but there are also notable differences. Perhaps, most importantly, is the difference in size of the various marketplaces. For example, in England, in "1880 there were 380 new novels 
published. In 1886 this figure had risen to 896 and in $1895, \ldots$ 1,315 new 'adult' novels were published" (Leary and Nash 199). By comparison, the mid-1930s, as a result of the Depression, saw less than a dozen new English-Canadian novels published a year. Secondly, by the time Canadian authors were beginning to discuss the nature of authorship, the proliferation of increasingly commodified forms of printing were beginning to become well-established, which meant that the critiques of and disdain for authors writing "lowbrow," or even middlebrow, literature was decidedly different. For example, as Leary and Nash argue, nineteenth century authors consistently relied on writing for newspapers and periodicals, or writing genre-fiction, to pay the bills. Although often done anonymously, even some of the most canonized authors relied on their ability to sell their work within the marketplace. In Canada, the mid-twentieth century saw a strong modernist aversion to mass culture, especially the increase in the commodification of literature, as previously discussed.

If there is a necessary first step towards the development of authorship as a profession, it must be acquiring adequate copyright protection. As Mark Rose notes, copyright is essential for the modern conception of authorship, as it endows the authorwork relation with "legal reality, [which] helps to produce and affirm the very identity of the author as author" (2). While copyright assured authors proprietorship over their work, the lack of international copyright hindered the development of professional authors in England, the United States, and Canada. In England, the lack of an international copyright law meant that most "authors were at the mercy of their publishers, while authors and publishers were bedevilled by American piracy" (Bonham-Carter 90). In turn, American authors likewise found the lack of an international copyright law 
crippling, as they "received no income from sales of their works in England. Moreover, they had to compete, in the United States, with cheap reprints of popular British works" (Bell 70). As Charvat astutely notes, a "Lack of international copyright ... worked both ways," (31) with publishers preferring to pirate successful works from across the pond instead of taking a chance on publishing the work of native authors. As the first chapter of this dissertation explains, copyright concerns plagued Canadian authors, and Canadian literature, in a similar fashion.

Changes to the copyright act in Canada led to the creation of the country's first association of authors, the Canadian Society of Authors. In 1899, with changes to the copyright legislation on the horizon, Goldwin Smith "led a distinguished group of Toronto authors, editors, and journalists to organize the Canadian Society of Authors" (Cambron and Gerson 130). The society had the goal of "rendering the Canadian market a separate one" from England and the United States (qtd. in Tippett 22), and membership to the Society was "restricted to Canadians who had written and published at least one book" (Cambron and Gerson 130). Although its aims were similar to the C.A.A.—“"to promote the production of literature in Canada, and the interests of Canadian authors" (qtd. in Cambron and Gerson 130) — it only remained active for ten years. Despite its short existence, the creation of the society shows that although Canada experienced a delay in the arrival of authors as a professional group, Canadian writers came together to collectively fight for their rights at more or less the same time as their counterparts abroad.

When Canada made its first attempt at legislating an international copyright act independently of England, writers came together to create the C.A.A, in a similar fashion 
to the Society of Authors. Similarly, the refusal of the United States to reciprocate British and European copyright protection for international authors "provoke[d] a fresh attempt among British authors to combine for their own protection" (Bonham-Carter 80). Like the C.A.A., the formation of the first author association in England was led by an internationally successful author who, like Stephen Leacock, felt that copyright laws allowed others to profit from his work - namely, Charles Dickens. Upon the realization "that his publishers had been making a fortune out of his books while he had not ... He raged and fumed; he talked over the subject with other men; he found them full of bitterness ... and he agreed to join them in an attempt to affect, by combination, a remedy of the wrongs of himself and his fraternity" (Walter Besant qtd. in BonhamCarter 81). As a result, the Society of British Authors was established in 1842. The Society lasted less than a year, despite attracting about a hundred members, and was heavily attacked by the author Walter Besant, particularly for the association's belief that "authorship is a profession as distinct as law or medicine; and that it is possible to unite its members, as those called to the Bar are united, into a guild or company governed by its own laws" (qtd. in Bonham-Carter 83). Forty years later, in 1883, the second Society of British Authors was established, with Poet Laureate Alfred Tennyson as its first president.

This second attempt at establishing an authors association was much more successful, and shared many similarities with the C.A.A. The Society of British Authors was established in the same year that the Conferences on Copyright took place in Berne - this latter event would lead to the formation of the C.A.A. Two of the Society's three main objectives were "the need for an international copyright convention with the 
USA" and "the maintenance of friendly relations between authors and publishers." As discussed in the first chapter, these central beliefs - fair copyright, and better relations with members of the book trade-were essential to the C.A.A.'s mandate as well. The Society faced objections, many of which anticipated similar criticisms faced by the C.A.A., such as its support for friendly relations with publishers, and its critics questioning whether authors could really form a successful trade union. The Society also quickly faced ridicule in the form of satirical poems and newspaper articles (BonhamCarter 122-23). The Society also had a two-tier membership, with Members, "authors of at least one full-length work, published or performed" and Associates, who "were aspirants" (Bonham-Carter 124).

The Society of Authors in England, Victor Bonham-Carter argues, is "probably the most successful writers' association in the history of literary authorship" (12). The Society had many successes, which included "demystifying" the publishing industry for its members, forcing publishers to change their practices, and helping in disputes between authors and publishers (Bonham-Carter 12-13). In the United States, the Association of American Authors was founded in 1892, and was replaced ten years later by the Authors League of America. Bonham-Carter, however, argues that these organizations "have not been especially influential on authors as a class, or on the publishing industry" and that "None of these groups had the influence of the Society of Authors" $(13,14)$. 


\section{Authorship Studies in Canada}

Although authorship studies, as a sub-field of book history and print culture studies, is a well-researched field in both England and the United States, it is very much an emergent field of study in Canada. ${ }^{16}$ The emergence of authorship studies in Europe and the United States, as outlined in the previous section, shows how Canadian book history would benefit from similar studies. The last sixteen years have seen a number of texts published that help to create a foundation for this area of research. Notably, these texts, for the most part, do not focus on authorship broadly, but instead focus on exceptional individual authors - authors that stood above their peers. For example, Clarence Karr's foundational study of authorship at the turn of the twentieth century - the 'golden age' from 1890 to 1920s which saw a boom in the market for mass-marketed fiction-is a reclamation project, and as such, focuses on authors whose works have typically been cast in "a traditionalist mould of popular, sentimental romance fiction" (Authors 9). These authors, however, are all remarkable in their own way, as Karr notes: Ralph Connor was "among

\footnotetext{
${ }^{16}$ Authorship studies, as discussed in this introduction, is a sub-field of the academic field known as book history. Although book history emerged as a field of research in the1970s, it was not widely adopted in Canada until a couple of decades later. In 1999, Imre Szeman edited a special collection of Essays on Canadian Writing "to draw attention to how marginalized materialist criticism has always been in Canada" (11). He argues that the first scholarly work that "introduced the possibility of a materialist turn in Canadian literary studies" (12) was Paul Cappon's In Our Own House published in 1978, noting that "it seems to have failed to spark the fire of materialist analysis in Canada" (12). However, since book history is an interdisciplinary field, with roots in bibliography, literature, and history (among other fields), Patricia Fleming has argued that traces of book history research in Canada can be found as far back as Marie Tremaine's A Bibliography of Canadian Imprints, 1751-1800 published in 1952. Book history, as a field of study in Canada, became solidified in 1997 when a group of scholars launched the History of the Book in Canada/Histoire du livre et l'imprimé au Canada project. This project published a comprehensive threevolume interdisciplinary history of the book in Canada, published in both official languages, with articles from one hundred and seventy-two authors working in a variety of scholarly fields.
} 
the first, and also one of the most successful, authors to use the adventure story as a vehicle for communicating a modern religious message;" Robert Stead "was a pioneer of the agrarian or homestead novel;" Nellie McClung was "part of the first generation of Canadian feminist writers, while Montgomery helped to define a new genre focusing on childhood;" and Arthur Stringer was "one of the North American creators of a new type of crime fiction" (9). Similarly, Lorraine York's examination of literary celebrity in Canada, and her more recent examination of Margaret Atwood and the labour of literary celebrity, both focus on the exceptional author, as does Joel Deshaye's recent work on Canadian poets who have found celebrity. As well, since the 1950s there have been a number of single-author studies published in Canada providing an in-depth analysis of the oeuvre of a single author. These texts, however, differ from these more recent studies on authorship, as these single-author studies rarely take a book history or print culture approach, and as such, do not question the construction of the category of author. It is this concern with the author as a historically contingent category that authorship studies, as a sub-field of book history, is primarily interested in.

The editorial approach of History of the Book in Canada was to present a number of small studies that are broad in their perspective, aiming to describe authorship in general, as opposed to studying specific authors (although this latter aim is accomplished with accompanying case studies). In volume three (1918-1980), for example, Carole Gerson and Marie-Pier Luneau's chapter "Social and Cultural Profile of Writers" and Frank Davey's chapter "Economics and the Writer" both offer empirical data about authors and their income, covering over sixty years of history. These well-researched articles aim to capture a sense of the "author" in Canada, as opposed to a specific author. 
Similarly, Janet B. Friskney and Carole Gerson's "Writers and the Market for Fiction and Literature" and Clarence Karr's corresponding article, "Writers and the Market for NonFiction," both offer excellent overviews of the market, but avoid focusing too closely on specific examples.

This project emulates the methodology found in these essays, albeit on a larger scale. Instead of focusing on specific authors, it uses a book history and print culture methodology to examine the debates around authorship more generally, by placing the debates within the social, political and economic milieu in which they arose. Leslie Howsam defines this methodology as "a way of thinking about how forces within the media culture of any era have acted upon the authors and compilers who produced the works that became books and periodicals during that era" (3). As such, my dissertation relies heavily on documents—-published and archival—contemporary to the time period, to properly identify the perspective of the time. While the Canadian Authors Association is the spine of this study, it offers insight into the complicated interrogations surrounding the concept of authorship in the first half of the twentieth century, in which the C.A.A. was only one participant—albeit, an important one.

The C.A.A.'s archives, located at the Library and Archives Canada (LAC), are incomplete, especially for the first several decades of the association's existence, as the C.A.A. did not begin to archive its records systematically until the late 1980s. At this point, it attempted to consolidate its archives, and retrieve material that had been deposited at various repositories across Canada. In 1998 the C.A.A. deposited its archives at the LAC, although it had not been successful in consolidating all of its archives leaving a variety of smaller archives, usually of specific local branches, spread across the 
country. While I consulted the C.A.A.'s archives at the LAC, the records were incomplete. As a result, I consulted the personal archives of prominent literary figures, including Earle Birney, Charles Clay, J.L. Granastein, and William Arthur Deacon.

I relied most heavily on the archival records of Deacon, especially in chapter two. My primary reason for this reliance was because of completeness of Deacon's archiveshe kept excellent records, relating to both the C.A.A. more generally and to the Governor General's Literary Awards. Further, Deacon was in constant correspondence with the most important figures in the literary field in Canada, and much of this correspondence (including letters sent and received) has been archived. As a result, Deacon's archives filled in many of the gaps left by the C.A.A.'s official archives. There are, of course, some challenges that ensue from relying on a single archive so heavily. The most obvious limitation is that all archives are inherently biased, through what documents have been deposited, and more importantly, by the documents that have been left out. As a result, by relying heavily on a single archival source, it is possible that the resulting research will share, or at least echo, this bias. In writing this dissertation I was acutely aware of this limitation, and wherever possible, attempted to verify or corroborate the information found in Deacon's archives with secondary sources. The second challenge that comes from relying on a single archival source so heavily is that the content of the archive determines what can, and cannot, be written about. In other words, the direction of the research is often determined by what is in the archives. This limitation is most clearly seen in chapter two, where having access to Deacon's archive allowed me to write indepth about the judging process of the GG awards. I was unable, however, to write much 
about the judging process for the years that Deacon was not directly involved, due to a lack of archival records for this period.

Much scholarship in authorship studies, and this dissertation, benefit from the work of Pierre Bourdieu, particularly his work on the field of cultural production. Bourdieu insists that to study a work of art it is necessary to not only consider the work of art itself, but it is also necessary to understand the cultural moment—with all the various competing power relations at play — in which the work of art was produced, circulated, and was consumed. Importantly, this type of research cannot simply consider "the direct producers of the work in its materiality (artist, writer, etc.)" but must also consider "the producers of the meaning and value of the work-critics, publishers, gallery directors and the whole set of agents whose combined efforts produce consumers capable of knowing and recognizing the work of art as such" (Field 37). Art needs to be understood "as a manifestation of the field as a whole" (37), Bourdieu argues, and studies of authorship that explain how the literary field of specific countries, at specific times, understand "authorship" help conceptualize literature as a manifestation of a historically specific field. Essential to understanding a literary field, Bourdieu argues, is understanding how various forms of capital operate within it. Capital, which "represents a power over the field (at a given moment" ("Social" 724), is primarily divided into economic capital, cultural capital, social capital, and symbolic capital. These concepts—especially symbolic capital, "commonly called prestige, reputation, renown" ("Social” 724)—are explored in more detail in chapter two, which focuses on how the C.A.A. employed the Governor General's Literary Awards to consecrate specific authors. 


\section{Chapter Breakdown}

This dissertation is organized chronologically, with each chapter focusing on one or two of the C.A.A.'s major initiatives. Chapter one focuses on the first decade of the association's existence, and discusses its lobbying of the government for copyright reform, as well as the creation and running of Canadian Book Week. In both of these initiatives, the C.A.A. had to define the role of the author. The association, however, employed contradictory concepts of authorship. While lobbying for changes to the Copyright Act, the association argued that an author's contribution to the creation of a book was of greater importance than the labour of the publisher or printer. During Book Week, however, the association was criticized for working alongside publishers in an attempt to market books, and in response, the association argued that authors were similar to other labourers in the literary field, and were entitled to influence the conditions upon which authors' products were sold. This chapter follows the development of this complicated emergent conception of authorship, in which the C.A.A. was simultaneously arguing that Canadian authors were the same as, as well as superior to, other labourers in the literary field.

Chapter two examines the C.A.A.'s role in creating and running the Governor General's Literary Awards from 1936-1959. Fifteen years after its founding, the C.A.A. had gained enough symbolic capital that it could grant literary awards that could bestow cultural capital upon winning authors. In analyzing archival records, this chapter explores 
the ways in which the C.A.A. attempted to use the awards to influence the type of literature, and by extension the type of authors, that should be seen as acceptable by the reading public. Although not always successful, the C.A.A. attempted to influence the GG awards so that they were awarded to authors who supported the association's views of literature. Instead of imposing an increasingly rigid hierarchy over what constituted as literature, as advocated by modernist poets at the time, the awards were used to champion middlebrow writing, living wages for authors, and a national literary culture.

Chapter three examines the rise of government patronage of the arts in the 1950s, with a focus on the role played by Canadian authors. By the time the Canada Council was established in 1957, it was more or less universally acknowledged that authors played an important role in the nation, and were, as a result, worth supporting financially. However, during the decade-long lobbying for government patronage, two competing conceptions of authorship emerged. The first was articulated by the Canadian Writers' Committee, a group of Canadian modernists who adopted a hierarchy of authorship, which advocated for a select few authors of "merit" as being worthy of funding. In contrast, the C.A.A. argued that it was difficult for any Canadian writer to live by his or her writing in Canada, regardless of genre, and that the government should attempt to support all Canadian writers equally. While the C.A.A. eventually lost the debate, this chapter shows that the modernist's conception of authorship was not shared by all writers, and was heavily debated.

Finally, the conclusion briefly looks at the Canadian Authors Association following the 1960s, and why the association lost much of its cultural influence. Specifically, it examines how the stereotypes of the C.A.A.- particularly its association 
with amateurism — became the accepted view of the association, and considers the association's positioning alongside the newly formed Writers' Union of Canada, a group composed exclusively of "professional" authors. Authors associated with the Union tried to craft a narrative of Canadian literary history that saw authorship prior to 1960 as composed of amateur writers, epitomized by the C.A.A., and authorship after 1960 as being composed of professional authors. This dissertation, in examining how the Canadian Authors Association articulated its view of authorship, shows how this narrative ignores the conflict found in trying to define the profession in the first half of the twentieth century. 


\section{Chapter One: Copyright Reform and Canadian Book Week}

The end of the nineteenth century in Canada saw fiction become "as commercialized a business as any other as it adjusted to mass production and global marketing." A coalescence of factors was behind the shift: cheaper paper, new and more efficient machinery, compulsory education, the completion of the railway, stronger copyright laws, and committed readers through established literary societies and clubs (Karr, Authors 27; 27-34). Karr argues that these changes allowed for the development, from the 1890s through the 1920s, of writing and reading, and resulted in mass-market fiction flourishing in Canada (3). At the same time, these developments saw some resistance by the literary elite, who feared that the line between culture and commerce was being blurred, which Janice Radway has referred to as the "scandal of the middlebrow." Even with this resistance, however, by the end of this period, it was possible for the first group of Canadian authors to acquire international recognition. Despite the simultaneous exodus of Canadian authors to New York and London (Mount), Canada was beginning to have a recognized group of professional authors at home.

Even with this small group, the very definition of authorship was much debated in Canada during the 1920s, first during the copyright reforms of 1919-1923 and then during the establishment of Canadian Book Week. At the center of both of these debates was the newly established Canadian Authors Association. These debates, when contrasted with each other, demonstrate that the attempt to define the role of the author was a difficult task, and one that changed depending on the context. While it appears that the romantic notion of the author as genius was being slowly replaced with the notion of 
the author as skilled labourer, worthy of fair compensation for his or her mental labour, the hierarchical positioning of the author-labourer over other labourers in the book trade (such as the printer or bookseller) evolved in a way that suited the needs of authors. For example, during the copyright debates, when members of parliament in favour of a new licensing clause argued that the printer and publisher were entitled to the same protection as authors, they were countered with a rhetoric arguing that the product of an author's labour deserved special treatment. During Canadian Book Week, the C.A.A. faced critics who argued that authors were overstepping their assigned roles by attempting to influence the literary marketplace. To counter these critiques, the C.A.A. argued that writers were similar to all other skilled labourers in the book trade, and were entitled to influence the conditions within which their products were sold. In the first case, the C.A.A. was arguing against publishers and printers, in an attempt to suggest that authors were more worthy of government protection. In the second case, the C.A.A. was willingly cooperating with publishers and booksellers in an attempt to influence the marketplace-i.e. sell more books. This intervention into the marketplace, however, drew criticism from modernist writers and other critics, who were resistant to the idea that authors should be directly involved with commerce. Importantly, these two attempts to define Canadian authorship were occurring simultaneously. In essence, during the 1920s, the C.A.A. was simultaneously arguing that Canadian authors were the same as, as well as superior to, other labourers in the book trade.

It is useful to remember that these debates around authorship, and in particular, authorial labour, occurred at a specific historical moment. For example, 1919 was "a year of strikes," with over 420 strikes fought in Canada (Palmer 200). These strikes made it 
necessary for "ruling authority to put a stop to what appeared to be a threat to the very foundations of civil society" (200). As a result of this conscious attempt to quash the labour movement, the years from 1919 to the mid-1920s saw union membership, in a variety of professions, decline across the country, and anti-union tactics employed in industrial settings (219-21). So, while the C.A.A. was trying to argue for the importance of authorial labour, other labourers around the country were fighting "to preserve what was increasingly coming under attack from capital: the wage, the union, [and] the customary conditions of work" (221). The creation of the C.A.A., the "union" of the inkpot, insisted on viewing writers as skilled labourers in the book trade - a debate that took up much of the government's time in the period - while other labourers across the country were seeing their rights come under attack. Insisting on viewing themselves as skilled labourers made the C.A.A. more akin to a craft union instead of an industrial union, the former of which had more state respect in the 1920s.

This chapter follows the development of the complicated emergent conception of authorship that developed in the 1920s. The first half of this chapter focuses on the C.A.A.'s attempts to reform the Canadian Copyright Act, while the second half focuses on its establishment of Canadian Book Week. The thread that runs through both of these sections is how the Canadian Authors Association attempted to define for itself, as well as the Canadian public, how it understood the role of the author in Canadian society, and how it conceived of the role of the author in relation to other members of the Canadian book trade. These debates around the rise of authorship in Canada insist on a reappraisal of the canonized narrative, which associates the rise of authorship in Canada with the rise of modernist writers. 


\section{The Road to Montreal: The "birth [of] a new profession"}

In 1919, the first issue of the Canadian Bookman (which two years later would become the official organ of the C.A.A.) begins with a two-page editorial dedicated to "bookishness" in Canada. The editorial begins by bemoaning the fact that "There is too little Bookishness in Canada" ("Bookishness"). This lack of "bookishness" refers to a lack of reading in general, not just the reading of Canadian books, although the two-page editorial does end with the hope that the Canadian Bookman will "cause two books to be read where one was skimmed before (and those two to be better books and more Canadian books than was the one)." The editorial lists many of the typical reasons why Canadians were not reading more books, before beginning the rallying cry: "the true friend of the Book must bestir himself and seek to defend the Book's proper territory." The "true friend" of the Book is vast, for:

The Book is a singularly composite product. To place the completed article in the hands of the consumer requires the services of the author, for the making of it; the publisher, for the physical production of it; the bookseller and the library, for the distribution of it. Within the world of books, the interests of all these differing classes are diverse and, in some respects, competing. When it is a question of defending the Book itself against its rivals, of advancing it in the affection and esteem of the public, their interests are indistinguishably one.

It is these common interests, the interests of the Book itself, which the Canadian Bookman is designed and pledged to serve. 
This rallying cry for camaraderie amongst all members of the publishing industry was taken up by the C.A.A a few years later during Canadian Book Week. The Canadian Bookman, and later the C.A.A., appears to understand that making changes to the literary field requires the participation of all its agents. However, as soon as the interests of these groups were in competition, as they were during the copyright reform of 1919-1923, the camaraderie-spirit quickly dissolved. Two issues later, in an editorial addressing a new copyright bill being discussed in the Senate, the Canadian Bookman asked what it presumably understood as a rhetorical question, "Is a printer or a writer more important to this young Dominion?" ("Printers or Authors" 8). This opposition between authors and printers was one of the main obstacles in establishing a Canadian copyright act, which would make it possible for Canada to adhere to the criteria of the newly revised Berne Convention.

The Bookman's editorial on the new copyright bill was written in response to "Bill E," which was given its first reading in the Senate on March 20, 1919. A week later it was read for the second time, before being sent to a Special Committee for a more detailed consideration. No mention is made of the bill in the Senate until May 26 when Senator Hewitt Bostock inquired on the current state of the bill. Senator James Lougheed responded that the Special committee "has had several sessions ... entirely devoted to hearing the different delegations that have come to Ottawa to make representations. A great deal of conflict has been evident as between those opposed to the Bill and those favouring it" (Senate, $13^{\text {th }}$ Parl. $2^{\text {nd }}$ sess. 498). The root of this conflict, which would be debated over the next few years as various copyright bills attempted to make their way through both the Senate and the House of Commons, was the inclusion of a licensing 
system. While the specifics of the licensing system varied over the years, being amended and altered in different versions of the bill, the core principle remained the same: any Canadian printer or publisher could apply to the government for a license to publish any work not originally published in Canada, and to attain the necessary copyright to do so. This unique licensing system was the result of Canada's proximity to the United States.

The United States did not join the Berne Convention, meaning that they were not obligated to respect the copyright of authors from other countries. Alongside this, the United States' copyright law stated that a work had to be published by an American publisher and printed (including having the type set) in America if the author wanted to retain copyright to his work in the United States. As a result, Canadian authors, faced with a small Canadian market for books, and desiring to retain their copyright in the United States, often published their works south of the border. Canadian publishers and printers, therefore, were often unable to compete for works by Canadian authors, because they had access to a much smaller market. ${ }^{1}$ The licensing system that was being considered as an addition to the copyright law was created to help these Canadian

\footnotetext{
${ }^{1}$ When testifying before a 1925 special committee of the House of Commons on amending the 1921 Copyright Act, John Murray Gibbon explained how a Canadian author typically found a publisher: The usual practice of the Canadian author of fiction is to submit his manuscript to a Canadian publisher, who in most cases is located in Toronto, and who, if he likes the manuscript, will enter into negotiations for publication. Except in the case of a very popular Canadian author the Canadian market rarely exceeds 2,000 copies, and the cost of setting-up and printing in Canada is so high that an average work of fiction could not be profitably produced or marketed at the standard price for new fiction, namely $\$ 2 \ldots$ The Canadian publisher, who is in almost every case affiliated with the American publisher, goes to his American affiliations to see if he can persuade the American house to take up this book and print an edition for the United States and he will purchase from the American publisher the 2,000 copies, with the imprint of his own name as Canadian publisher, at a price which will enable him to sell it in Canada at the $\$ 2$ figure.... Very few American houses will publish a work of fiction unless they see an opportunity for 5,000 copies. ... But if they have the Canadian sale of 2,000 copies they will generally take a chance on the balance of 3,000 knowing the Canadian order for 2,000 would cover the printing cost ... Now that is the actual practice of, I would say, 90 per cent of Canadian authors of fiction. (John Murray Gibbon qtd. in House of Commons, Proceedings 10-11)

Gibbon argued that the licensing clause hurt Canadian authors, because American publishers might be less likely to take on Canadian novel because the Canadian author can no longer guarantee the 2,000 Canadian copies, as any Canadian printer or publisher could apply for a license.
} 
publishers and printers by allowing them to print books by Canadian authors that were originally printed in the United States. This, however, angered Canadian authors, as they felt that the Government was placing authors "completely at the mercy of a small group of publishers ... [for the authors'] very copyright in this country" ("Printers or Authors?" 7). If the licensing clause was included in the copyright bill, Canadian authors felt that they would be negatively affected; likewise, printers and publishers felt that the exclusion of such a licensing clause would hurt their ability to publish and print Canadian material. It is in response to this situation that the Bookman asked "Is a printer or a writer more important to this young Dominion?"

Bill E never left the Special Committee to return to the Senate for its third reading, partly due to the lobbying efforts of Canadian authors. As Senator Lougheed explained in the Senate, one of the reasons the Bill never left the Special Committee was because "the better known and more important section of the authors of the Dominion are not in favour of the Bill as drafted" (Senate, $13^{\text {th }}$ Parl., $2^{\text {nd }}$ sess. 641 ). A slightly altered version of the copyright bill (Bill No. 37) was introduced in the House of Commons on March 26, 1920, which also contained a version of the controversial licensing clause. In response, the Canadian Bookman issued another editorial, although it was much more pointed than their earlier one; this new editorial twice refers to "the evils" that this licensing clause would produce. In this editorial the Bookman views the proposed copyright law as a form of "retaliatory legislation against the United States," arguing that instead of protecting Canadian publishers and printers, the Canadian government is actually trying to bully the United States into changing its copyright law ("Copyright Law" 3-4). The editorial suggests that this licensing clause "would materially increase the 
amount of printing done in the Dominion of Canada," but that the printing industry in Canada "is in an extremely flourishing condition, and we should count the cost very carefully before taking any steps to give it further artificial stimulus" ("Copyright Law" 4). In the same breath as suggesting that the Canadian printing industry does not need any government support, the Bookman then suggests that neither the printer nor the government should be trusted with authors' copyright:

[Under the suggested licensing system] It would, in fact, be possible for [a Canadian book manufacturer] to treat the property of the author, or the author's assign, in any way which might be likely to enhance his own profits, subject to no control by the author, and only to such vague and half-hearted limitations as might be expected from a bureau of Government officials. This whole proposal is nothing more than old-fashioned piracy, dignified by a Government license. ("Copyright Law" 4)

The editorial concludes by suggesting that the "private interest" of publishers and printers is holding the "general interest" of a modern copyright law hostage. These concluding remarks suggest that amending the copyright act to appease the authors' desires would be better for a larger group of people, as opposed to the narrow considerations of the licensing clause. What this rhetoric fails to acknowledge, however, is that any copyright law is an agreement between government and copyright holders over how long the text should remain out of the public domain. In other words, copyright law itself is never in the "general interest" of the reading public, as it limits the public's access to a text. And, in the case of the proposed licensing clause, the government is actually attempting to make Canadian texts more readily available to the Canadian public by allowing for them 
to be more easily printed, and thus for sale, in Canada. Thus, the author's motivation is as driven by "private interest" as the publisher or printer. The hostile language of this editorial, however, becomes the norm for the C.A.A. when discussing copyright change over the next few years.

Like Bill E in the Senate, no progress was made on Bill. No 37 after its first reading in the House of Commons. On February 28, 1921, the copyright bill was reintroduced into the House of Commons (Bill No. 12) for its first reading. This was the third bill to attempt to reform copyright introduced in parliament within a two-year span. Within two weeks of Bill No. 12 being introduced, famed Canadian author Stephen Leacock, along with B.K. Sandwell, editor of the Canadian Bookman, organized a twoday conference at McGill University, where Canada's writers met to discuss the copyright situation. As a result, on March 12, 1921, the Canadian Authors Association was founded.

\section{“A Very, Very Troublesome Question": The Fight for Copyright ${ }^{2}$}

While elsewhere—-such as in the Canadian Bookman's opening editorial—Canadian authors and the C.A.A. acknowledged the necessity of a strong Canadian publishing industry to support an independent Canadian literary marketplace, during the copyright debates they became staunch opponents because of a vital difference in their understanding of the role of a copyright law. For Canadian authors, the purpose of a copyright law was to guarantee complete control over their work, which they viewed as

\footnotetext{
${ }^{2}$ For a comprehensive history of the political debates around copyright that took place between 1919-1923, see Bannerman's Struggle (84-100) and George Parker's “Authors and Publishers on the Offensive."
} 
an inalienable right. For Canadian printers, and some members of parliament, copyright law could also be used as a form of protectionism, resulting in the interests of the country being placed over the interests of the author. In this view, copyright becomes a privilege granted by the state, which Herbert Mowat reminded the House of Commons, noting that “Copyright exists only by statute" (House, $13^{\text {th }}$ Parl. $5^{\text {th }}$ sess. 3848 ). Specifically, printers wanted the copyright law to include some form of protection, to ensure that Canadian books were being printed in Canada. ${ }^{3}$ The C.A.A. and Canadian writers were frustrated because on the one hand, the Berne Convention was telling them, and all other authors around the world, that the copyright of their work should be a guaranteed right in all nations. On the other hand, the Canadian government was telling Canadian writers that this right came with restrictions. In essence, Canadian writers were lobbying their own government to receive the same rights that Berne signatories had already accepted. As noted earlier, what made Canada's copyright reform so problematic was its proximity to the United States, which did not sign the Berne Convention. It is thus not surprising that on various occasions Members of Parliament bemoaned the difficulty of legislating a fair copyright act in this situation. Hugh Guthrie appropriately summarized the situation when he noted: "I do not know any more complicated piece of legislation which comes before the House than this same copyright question. . . . it has proved a very, very troublesome question" (House, 14 $4^{\text {th }}$ Parl. $2^{\text {nd }}$ sess. 2140).

John Murray Gibbon, reflecting on the copyright debates a decade later, suggested that the copyright bill had "been introduced by certain Canadian printers who had the

\footnotetext{
${ }^{3}$ The C.A.A. and the press argued that the licensing clause was a simply retaliatory action against the United States and its copyright law. While this is arguably a reductive view of the government's aims, it was clearly one consideration. As John Allister Currie argues, "The United States by their legislation have attracted a great deal of the world's book printing, and we must do something to keep the printing of the works of our own authors in Canada. This is what we are legislating for" (House, $13^{\text {th }}$ Parl. $5^{\text {th }}$ sess. 3841).
} 
notion that books which were best sellers in Canada should be printed in Canada whether the authors wished it or not" (5). In his memoirs, Watson Kirkconnell echoes this statement, although in a more derogative manner, by suggesting that "a lobby of jobprinters ... had successfully slipped through Canada's unsuspecting parliament a [copyright] bill" (Slice 290). While it is unlikely that Canadian printers were responsible for introducing the Bill—especially since it was introduced because of the desire of the British government to have Canadian copyright law comply with the Berne Convention (Bannerman 84) - it is clear that Canadian printers did lobby the government over the Bill, resulting in the implementation of the licensing system. Unfortunately I have found little documentation of printers' concerns, written from their united perspective. By contrast, Canadian authors had a number of venues, including the C.A.A.'s official organ and the public press, to express their view. As well, although the copyright bill went to a Special Committee of the Senate in 1919, and a Special Committee of the House of Commons in 1921, where evidence and arguments on behalf of all interested parties would have been heard, the records of these committees are not available. It is easy then, in reading contemporary accounts of the debates, to be swayed by the prominence of the authors' position. For example, the Canadian Bookman asks, rhetorically, “Are we prepared to obtain work for a hundred printers, at the cost of losing the presence in our midst of a hundred Canadian authors?" ("Printers or Authors" 8). Aside from omitting the fact that these printers are Canadian as well, this quotation suggests that very few printers would benefit from the copyright act. Sara Bannerman, however, states that in 1921, approximately 26,000 Canadians were employed in the printing and publishing industry, outnumbering Canadian authors thirteen-to-one (87). It should be remembered that 
printers played a vital role in Canada's literary marketplace, and have had their voices silenced in the decades since these debates took place. So while the government was tasked with bringing Canada's copyright law into alignment with the Berne Convention, it could not ignore the importance of the Canadian printing industry, and the impact caused by being so close to the non-Berne-complying United States. Attempting to reconcile these conflicting and competing interests into one law, understandably, proved difficult.

Although the early records of the special committees on copyright do not remain, ${ }^{4}$ the debate over copyright took up much of the time of the general committee of both the House of Commons and the Senate. And although, at times, the ministers felt ignorant of the laws and its implications - for example, during a debate in the House of Commons, Mr. Guthrie stated "I am ... satisfied now that apart from [J. A. Robb, Minister of Trade and Commerce] himself there is not a man in the committee at this present moment who understands this legislation" to which Robb responded "You might include me" (House, $14^{\text {th }}$ Parl. $2^{\text {nd }}$ sess. 2288) - the debates clearly demonstrate that a majority of the ministers did have a good understanding of the law and what was at stake. That being said, MPs had many differing opinions on what the copyright law should do, and whom it should protect.

What is perhaps most interesting about the House of Commons debates in 1921 were the ways in which members of parliament defended and attacked the licensing clause. Although it is never explicitly stated, through their arguments it is possible to discern the different ways in which Canadian politicians understood the role of authors

\footnotetext{
${ }^{4}$ In 1925, when the government tried to make amendments to the copyright law, the House of Commons formed another special committee, which felt that the discussions they held would be of interest to a wider audience, and had 1000 copies of the Special Committee proceedings printed.
} 
and their work in Canadian society. For the most part, proponents of the licensing system viewed Canadian authors as simply one agent among many, responsible for the creation of a book. In this view, authors do not deserve a greater representation than any of the other agents. This position was argued most strongly by Charles Doherty, Minister of Justice, who insisted that Canadian publishers and printers deserved "an opportunity to participate in the production of what may be called the material part of the work" (House, $13^{\text {th }}$ Parl. $5^{\text {th }}$ sess. 3831). It is evident that Doherty does not view Canadian authors with much respect, and at one point even "appeal[s] to the author, the Canadian author in particular, not to be absolutely selfish but to have some thought for the Canadian printer or publisher who has contributed his part to this book" (House, 13 ${ }^{\text {th }}$ Parl. $5^{\text {th }}$ sess. 3843). Despite this bias, Doherty makes some nuanced arguments, noting, for example, that "In the work there is the author's intellectual effort; there is also the printer's and publisher's material work" (House, $13^{\text {th }}$ Parl. $5^{\text {th }}$ sess. 3837). Supporters of the licensing clause, such as Doherty, who argued that a book encompasses far more than an author's words, ironically recall the C.A.A.'s own mentality, seen during its Book Week campaigns, where it argued for co-operation among all members of the book trade.

On the other hand, MPs who were against the licensing system, and therefore supported the authors' position, argued for the fundamental right of Canadian authors to have complete control over their work and its production. Henry Drayton suggests that to legislate otherwise would be "reinstating legalized piracy in the copyright law" (House, $14^{\text {th }}$ Parl. $2^{\text {nd }}$ sess. 2287). John Howard Sinclair disagrees with Doherty's line of argument, suggesting that "Neither the publisher nor any one else assists the writer, the book is the product of his own brain, and he has the same right as the maker of any article 
has always had to sell it to whom he pleases ... but we are removing from the author this control" (House, $13^{\text {th }}$ Parl. $5^{\text {th }}$ sess. 3840 ). He further notes that "the author ought to have complete control over the product of his own labour" (House, $13^{\text {th }}$ Parl. $5^{\text {th }}$ sess. 3841). Sinclair's conception of authorship, as akin to "the maker," identifies authors as artisans - self-employed, skilled workers. This conception of authorship, however, ignores the important and necessary labour of the other agents in the book trade, who turn an author's work into a book. Elsewhere, this connection between the intellectual labour of an author, and the material commodity of a book, is made explicit, while still defending the author's right as superior. For example, in the Senate, those in support of Canadian authors argued that the licensing clause was a violation of the author's right to property. If there is anything that is sacred it is the right of property. Who would deny to a man the right to dispose of his property, whether movable or immovable, as he pleases - at the time and upon the condition he prefers? Then why deprive authors of that right? Is it because they are poorer than proprietors generally are? Is it because intellectual productions are worth less than industrial products? ... Those poor Canadian authors are miserable enough, and I think we should not make them worse. (Laurent-Oliver David qtd. in Senate, $13^{\text {th }}$ Parl. $5^{\text {th }}$ sess. 651 )

Other Senators agreed that the author's claim to copyright should be founded on the belief that their intellectual output was a form of property, such as Charles-Philippe Beaubien who notes, "For my part I would be very sorry to see Canada one of the only two countries in the world where that property is not considered absolutely sacred" 
(Senate, $13^{\text {th }}$ Parl. $5^{\text {th }}$ sess. 652 ). Although there was often discussion of reaching a compromise, it became clear that no compromise would satisfy both groups.

Much of the rhetoric found in these debates, such as the notion of the author as proprietor of his or her work, and entitled to protection of this property, echoes copyright debates that had taken place in England during the previous centuries. ${ }^{5}$ Mark Rose argues that "The distinguishing characteristic of the modern author . . . is proprietorship; the author is conceived as the originator and therefore the owner of a special kind of commodity, the work" and that "This representation [of the author as proprietor] was dependent on the classical liberal discourse of property as represented, most famously, by John Locke's notion of the origins of property in acts of appropriation from the general state of nature" (Rose 1,5). While the specifics of the debates have changed over the years, Rose argues that this representation of the author as proprietor of his or her work has become central in distinguishing the author, and his or her work, from other labourers or inventors. This distinction becomes necessary. Doherty's argument, at its core, is that the labour of everyone involved in the creation of a book is worthy of equal protection; the author does not deserve special recognition. In arguing against this, the supporters of Canadian authors employed a similar language of labour, such as Sinclair's notion that authors ought to have complete control over their labour. Implicit in this argument,

\footnotetext{
${ }^{5}$ For example, compare the comments made by Canadian Senators to Mark Rose's analysis of copyright debates from the eighteenth century in England:

"Labour gives a man a natural right of property in that which he produces: literary compositions are the effect of labour; authors have therefore a natural right of property in their works." This was the essence of the argument for the author's right as it was made in the law courts and in the controversial pamphlets associated with the literary-property debate. This argument was compelling precisely because it so perfectly incorporated the classical liberal discourse with its assumptions about the priority of the individual and the sanctity of property. Liberty and property: the freedom to dispose of that property as he saw fit. These were the principles inscribed by reason in the very order of nature. How could they be denied in the case of the author? (85)
} 
however, is the recognition that the author's labour is special or different from other forms of labour; Sinclair does not appear to find it problematic that his argument against the alienation of authorial labour could as easily apply to the labour of the printer or publisher. As Rose notes, the reason that authorial labour is unique is because it produces "a special kind of commodity, the work." Such a view of authorial labour, as being hierarchically above other forms of labour in the literary field (and therefore worthy of government protection), also explains David's conflation of a work as being both an author's property and a product of her labour. The copyright debates that took place in Canada between 1919-1923 were, firstly, about whose labour was worthy of government protection, and secondly, about the role of Canadian authors (and their works) in Canadian society. Problematically, the appeal by supporters of Canadian authors that authorial labour was unique because it produces literature is diametrically opposed to the way that the C.A.A. presented themselves when defending Canadian Book Week. As discussed later in this chapter, during Book Week the C.A.A. stressed the authors' position as relative to the other labourers in the book industry, as simple producers of a commodity, not the producers of "literature." In these debates during Book Week, a key component of the C.A.A.'s positioning was that an author's product was not unique, but was a commodity like any other.

While some important questions about the role of the author, and the role of copyright itself, were raised through the various debates in the House of Commons and the Senate, these questions were often left unanswered in the attempt to choose sides between printers and authors. In this fight, Doherty decided to villainize Canadian authors: 
I would suggest to the authors that if they want to preserve the sympathy which I am sure all right-minded people have with their demand that their rights be given the widest possible interpretation consistent with the public interest, they do not take too uncompromising an attitude and say to this Parliament, for instance, or to any other legislative body: You must think of nobody else but me in regard to that work and to all the copies of it, although other people contribute to produce the copies; nobody is to have any consideration from Parliament except me, the author. (House, $13^{\text {th }}$ Parl. $5^{\text {th }}$ sess. 3842)

This attempt to cast authors as selfish and unpatriotic was taken up in the Senate as well, where John Lougheed, for example, questioned: "Is an author to be permitted to say: 'I am going absolutely to ignore Canada, and print this work in a foreign country, and snap my fingers at the Parliament that gives me the protection I demand.' It seems to me that there is a simplicity about that which would do credit only to a schoolboy" (Senate, $13^{\text {th }}$ Parl. $5^{\text {th }}$ sess. 654). These attacks did not go undefended. Senator Beaubien, for example, argued that a Canadian author's decision to publish in the United States was not unpatriotic or malevolent:

Do you think that the authors who go to other markets to have their books printed do so because they want to deprive their own country of the benefit of their works, or because they feel that they need a wider market? They go to the United States because they must have a larger field. If they could at the same time publish in both markets - and sometimes they do - they would be only too glad to do so. (Senate, $13^{\text {th }}$ Parl. $5^{\text {th }}$ sess. 656 ) 
Although the Senators and MPs did not villainize printers and publishers in the same way that they attacked authors, it was not beneath the C.A.A. to do so. For example, in an editorial in Queen's Quarterly, B.K. Sandwell writes "It is highly important that [the fight against the licensing clause] should have the support of every individual and every association of individuals in Canada interested in the advancement of human thought and the dissemination of beauty" ("Canadian Copyright Act" 187-8). Such phrasing, of course, suggests that Canadian printers and publishers were philistines. Unfortunately, this attempt on both sides to villianize their opposition, both in and out of parliament, often obfuscated the real issues.

\section{Authors "Treated Like Dogs": Copyright Enacted}

Despite the authors' lobbying, the licensing clause was not removed from the copyright bill, although some small concessions were made to appease some of their concerns. Copyright Bill No. 12 was passed on June 1, 1921, but was not proclaimed into law, out of concern that it would not satisfy the criteria of the Berne Convention because of the licensing clause. A few months later, in December 1921, the Conservative government was replaced by William Lyon Mackenzie King's Liberal government. The copyright bill was reintroduced into Parliament as Bill No. 24 on February 20, 1923. It was essentially identical to the 1921 copyright bill, and the debates that were held in both the House of Commons and the Senate were reminiscent of those held two years earlier. Due to concerns raised about the licensing clause satisfying the Berne Convention, the bill was amended. The licensing clause now only applied to works by Canadians and by 
creators/authors from non-Berne Union countries, such as the United States. As a result, the licensing clause really only affected Canadian authors. While the international press viewed the licensing clause as not meeting the spirit of the Berne Convention, it did not impact authors from other Berne Union countries and thus met the basic requirements needed to allow Canada to join the Berne Convention. The bill was passed with the newly amended licensing clause and was given royal assent on June 13, 1923.

Canadian authors and the C.A.A. were evidently frustrated that their lobbying attempts to have the licensing clause removed from the copyright act were not successful. At the C.A.A.'s 1924 annual convention, "criticism of the federal government for its copyright turpitude was so violent ... that Bob Stead, as a civil servant, felt moved to resign from the national presidency" (Kirkconnell, Slice 291-2). In 1925, MP Edgar Chevrier introduced a private members bill, Bill No. 2, in an attempt to repeal the licensing clause. As a result, a special committee was formed to discuss the possibility of making further amendments to the copyright act. ${ }^{6}$ The committee heard testimony from a variety of important agents in the literary marketplace, expressing a range of views on the licensing clause. Lawrence Burpee, national president of the C.A.A., was the first witness to be heard. Burpee began his testimony by repeating the now familiar call for camaraderie among all members of the literary marketplace, noting that "we and our friends the printers seem to view the licensing clause from opposing angles, we have none but the most friendly feelings for them." Burpee continued, however, noting that "[I] feel sure that when [the printers] have taken all the facts into consideration they will join us in asking for [the licensing clause's] repeal" (House of Commons, Proceedings

\footnotetext{
${ }^{6}$ For a concise summary of this special committee, see the section "What the 1925 Special Committee Discovered about the Book Industry" (158-63) in Parker's article "Authors and Publishers."
} 
2). Burpee's argument is an extension of the C.A.A.'s argument from 1921 when the new copyright law was first introduced - that the printing industry in Canada does not truly benefit from the licensing clause:

Only a very limited number [of Canadian publishers] actually publish Canadian books in Canada; and, if I am not mistaken, only one of these maintains its own printing plant. So that all the rather grandiloquent phrases about jeopardizing immense investments, imperiling national interest, injuring thousands of Canadian workmen, and putting the factories of Canada out of business, boils down to the problematical advantage or disadvantage of a handful of Toronto publishers. (House of Commons, Proceedings 2)

After presenting his arguments against the licensing clause, Burpee concludes his testimony by appealing to the committee's sympathies: "The poor devil of a Canadian writer is made the victim, while the mantle of Canadian justice and Canadian freedom is thrown over the authors of France and England, Italy and Spain. ... Each nation has its own way of honouring its man of genius. Our way is to treat him like a dog" (Proceedings 2). Burpee's appeal to the author as a man of genius is reminiscent of earlier debates about the special nature of authorial labour. This is the exact language, however, that Robert Stead, as President of the C.A.A., tried to distance the C.A.A. from when defending the idea of Canadian Book Week. Aside from suggesting that the C.A.A.'s executive did not all share the same view of authorship—Burpee replaced Stead as the President of the C.A.A. in 1924-Burpee's rhetoric here also suggests the difficulty in keeping the emergent idea of authorship distinct. Burpee's complaint that Canadian authors were treated worse by their own government than their government 
treats authors of other Berne countries is fleshed out by Chevrier: "the Canadian author in order to [have his or her copyright] be protected in Canada must print in Canada or undergo the humiliating effect of being licensed, while a Japanese printing his book in Czecho-Slovakia would be protected in Canada, while the Canadian author would not be" (Proceedings 6). While the C.A.A. had a more favourable ear at this Special Committee hearing than it did at previous debates, their arguments against the licensing clause had not fundamentally changed since the association's formation in 1921.

Following Burpee, John Murray Gibbon, former president of the C.A.A., made an independent report to the Committee. Interestingly, Gibbon was born in England, and was therefore exempt from the licensing clause, but made a report to the committee nonetheless. Gibbon's report is primarily concerned with convincing the committee that since the copyright law was proclaimed in 1923, the licensing clause had only been used once, to print a popular American cookbook. Gibbon argues that no decent publisher would use the licensing clause, even noting that "one publisher [had told Gibbon] that it would completely put him out of business, out of good relations with other publishers if he were to use [the licensing system]" (House of Commons, Proceedings 14). Gibbon concludes by noting, "It is a violation of good ethics and good business; it is not wanted by the Canadian authors, it is not really used by printers; it is a dead letter which stinks in the nostrils of right-thinking men; it is a corpse, and I say it should be removed" (Proceedings 14). Following Gibbon, Stephen Leacock presented a report, which was very accusatory and pointed, suggesting that the Canadian government was "stealing from [him]," and noted that "I am afraid there are some people in this country who would 
measure out the greatness of Shakespeare according to the number of copies of his works, and the number of employees who would set the type" (Proceedings 24).

Following this representation by Canadian authors, a number of other witnesses made testimonies before the committee, often in favour of the licensing clause. William Frank Harrison, for example, representing the Canadian National Newspapers and Periodicals Association, argued that the licensing clause was useful for periodicals. While providing insight into the state of the publishing industry in the 1920s, and the impact that the new copyright law was having, the special committee did not succeed in amending the copyright law. Although the copyright law was not amended, the seven years of debate surrounding the licensing clause itself may all have been for naught. ${ }^{7}$ George Parker, in his recent examination of the Canadian publishing industry in 1920s Canada, agrees with Gibbon, noting that "no one licensed the work of a Canadian author during the 1920s" (162), and adds that he has found no "instances of successful licensing in later decades either" (footnote 95, 162). Parker explains that the reason so few Canadian printers and publishers attempted to use the licensing clause that they fought so hard for is because American publishers took precautions to prevent license applications, often through agreements made with Canadian publishers (162-3). Parker concludes that while "The licensing sections were not removed from the law . . their impact was neutralized through such pre-emptive actions" (163).

\footnotetext{
${ }^{7}$ Lyn Harrington argues that despite its failure to remove the licensing clause, the C.A.A. could claim "some modest success" in affecting the legislation. She argues that the C.A.A. had an impact on the following changes to the copyright act through its lobbying efforts: "The clause regarding serials, which had been a great hardship to magazine writers, was withdrawn. The license term was cut from fifty years to five ... the author was assured of his royalties at a negotiated rate; he could buy as many copies of his own book as he desired; he could now demand the return of his manuscript and of the copyright which had originally been assigned to the publisher" (41).
} 
During the first decade of its existence, the C.A.A. was actively involved in two major initiatives, lobbying the government for copyright change and running Canadian Book Week. Importantly, these two initiatives were occurring simultaneously. Canadian Book Week was a yearly event, and the C.A.A.'s efforts to change the licensing clause in the Copyright Act lasted throughout the decade. As a result, the C.A.A., and its critics, often discussed these two initiatives as part of the C.A.A.'s larger mandate. So although the discussion in this chapter has been divided thematically to allow for ease of understanding, these two initiatives - and, more importantly, the C.A.A.'s positioning of the role of author in both—are intimately intertwined.

\section{Canadian Book Week}

Although the lobbying of the C.A.A. did not result in their removal, the licensing clause acted as a catalyst to bring together a group of authors into a "union of the ink-pot." These authors had come together in 1921 under a shared desire to improve their legal position within Canada, but it was quickly decided that this was not enough, and that they needed to become more active in other areas of the marketplace as well. Within months of its creation, the association had formed the idea for an annual Canadian Book Week. An early form of what Danielle Fuller and DeNel Rehberg Sedo have called a "mass reading event," Book Week was an annual event in which the C.A.A. teamed up with publishers and booksellers with the explicit purpose of encouraging Canadians to buy and read Canadian books. While sometimes portrayed as simply a patriotic attempt to strengthen nationalistic sentiments in Canadian readers, this is too simple an explanation 
for what Canadian Book Week was. Book Week was a way for Canadian authors to become active participants in the literary marketplace: by encouraging Canadians to buy (and read) Canadian books, the C.A.A. was hoping to create a readership for Canadian literature, who would, ideally, demand more of it. This intervention into the marketplace, however, was met with some resistance. As a result, the C.A.A. was forced to defend itself publicly, and the way in which it conceived of the role of the author. The role that the C.A.A. was publicly crafting for Canadian authors in the 1920s, however, appears to have been at odds with the arguments the association was making before Parliament over copyright reform.

In the early 1920s, the C.A.A. was critiqued for creating and supporting Canadian Book Week. These critiques often focused on the overtly patriotic aspect of the event and suggested that the C.A.A. was promoting "bad" literature. Literary histories of the association to date have taken this criticism of the C.A.A. at face value, and have not paid enough attention to the actions and opinions of the C.A.A. itself. This section emphasizes that for the C.A.A., the creation of a Canadian literary marketplace for Canadian writers was the primary concern-a concern that the C.A.A. would position as an attempt to support all Canadian writers. The attempt to create such a marketplace required a new conception of the role of the author in Canadian society, one that would support authors' direct intervention in the marketplace.

The C.A.A.'s first Canadian Book Week ${ }^{8}$ ran from November 19-26, 1921. It became an annual event that ran until 1959. In a newsletter distributed to members of the association in 1921, B. K. Sandwell described Canadian Book Week as: "a week devoted to propaganda in the interests of books written by Canadian authors, and more

\footnotetext{
${ }^{8}$ In 1921, the event was called "Canadian Authors' Week."
} 
particularly to propaganda for the increased sale of any such books by Canadian authors as may be obtainable this autumn from the Canadian Book Trade" ("Canadian Book Week"). Sandwell urged all members of the association to use any connections they had to push this "propaganda," aiming primarily at six main channels - the press, schools, libraries, churches, booksellers, and clubs and societies. The cover of the December 1921 issue of the Canadian Bookman, which at the time was the official organ of the C.A.A., lists the appropriate methods for disseminating information about Book Week: "Every known means of suggestions, from sermons to cartoons and from dinners to dynamite."

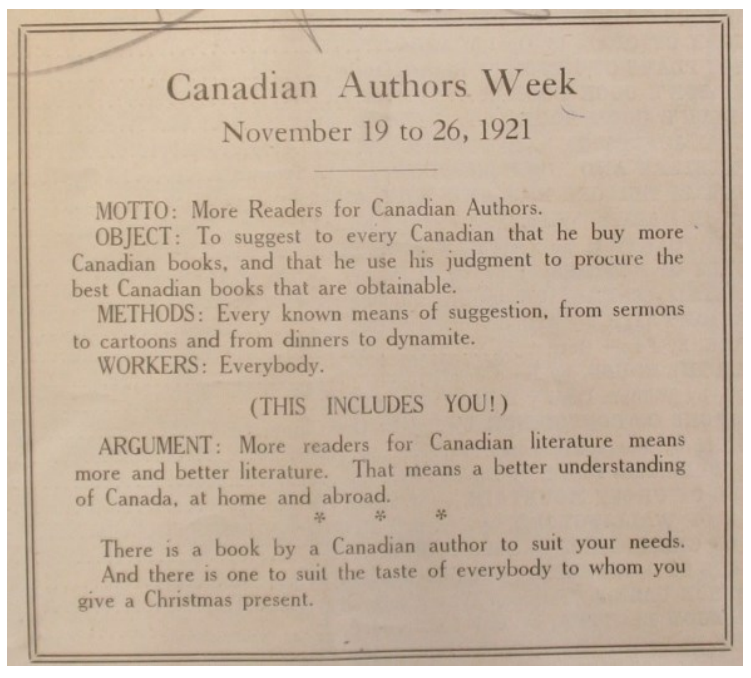

Illustration 1: Portion of cover of Canadian Bookman, December 1921

Reading through the Canadian daily press of the 1920s, it is hard to locate many articles discussing Book Week. This suggests that Book Week itself, as a national event, was quite ephemeral. Consulting personal letters and the press, one sees that events occurred, but there are very few records that explicitly describe what was discussed at these events, how well attended they were, how many occurred throughout the country, 
and so on. In her diaries, L. M. Montgomery documented her involvement in the first Canadian Book Week, offering a rare glimpse into this event:

Saturday, Nov. 19, 1921

Still rainy. This afternoon Mary and I went to hear Basil King speak in the auditorium in the Robert Simpson Co. store. Then we went to the big reception given by the Press Club to the Authors' Association. A horrible mob! Twelve hundred people packed together-nothing much to eat.

Monday, Nov. 21, 1921

... In the afternoon I went to Jarvis St. Collegiate and read and talked to an audience of about 800 girls. I enjoyed it. They were so eager, so appreciative, so enthusiastic. I felt at one with them from the start. I autographed about a hundred books and cards and then went to an I.O.D.E. meeting in Parkdale, gave a reading, answered innumerable questions, then went to Victoria College and spent a very dull evening listening to a couple of literary papers by erudite authors who could not stoop to be interesting as well as erudite.

The thing has been done- but they didn't do it. I nearly fell asleep. But at least the evening was restful.

Tuesday, Nov. 22, 1921

A full day_full of something at least. This morning I went to Moulton College and gave a reading and a brief talk to the girls thereof, writing a hundred autographs afterwards. ... At 4.30 I went to give readings in the auditorium of the 
Simpson store. I had a bumper audience. The room was packed and half as many more couldn't get in.... After it came the usual autographing and handshaking.

Wednesday, Nov. 23, 1921

... I went to Oakwood where I gave readings to an audience of 1,300 boys and girls. I felt rather nervous for I had never read to boys before and did not know if I could appeal to them. I gave the story of Dog Monday from Rilla, arranged to form a continued reading and my audience seemed to like it very much. I autographed 91 books. In the afternoon I went to the School of Commerce to read to the High School girls of Toronto. I had a very enthusiastic audience of about 1,500. Before I began to read they gave me a magnificent basket of big white and pale pink "'mums" in the "name of the girls of Toronto," which was very sweet of them. Afterwards I was nearly mobbed by a sea of girls wanting autographs. They nearly smothered me. I wrote about 400 autographs in half an hour. I was so tired that evening that everything seemed vanity and schoolgirls the vainest things of all.

Friday, Nov. 25, 1921

... This afternoon I went to Hamilton to autograph books. (25-28)

From Montgomery's perspective, Book Week appears to have been an incredibly well attended, albeit time-consuming, event, with Montgomery giving several readings a day. This type of detailed report of Book Week, however, is rare. Alongside Montgomery's fame, which probably would have drawn larger crowds, it is difficult to know with any 
certainty whether this schedule was typical for a Canadian author during Book Week. Nonetheless, it is possible to make some observations about Book Week from Montgomery's experience. Montgomery had a number of engagements throughout the week, all of which appear to have been well attended. In promoting Montgomery so actively, it is clear that the C.A.A. fully embraced authors who had achieved their success through genre-fiction. As discussed later in this chapter, relying heavily on best-selling authors like Montgomery_financially successful, an author of "children's literature," and, a woman - to promote literature in Canada was considered by the C.A.A.'s critics to be vulgar. It is also worth noting how many autographs Montgomery signed; despite the lament that Canadian writers had yet to produce any great literature, the reading public might have disagreed, with Montgomery's status as a literary celebrity clearly well established.

For a more general schedule, it is possible to consult issues of the Authors' Bulletin, the C.A.A.'s official publication, which listed all the activities each local branch of the C.A.A. undertook each year, often enumerating the many events associated with Book Week. Although these lists lack detail, they do demonstrate the wide array of events that took place in major Canadian cities for this annual event. For example, in 1925, the Ottawa Branch reported:

The Ottawa executive undertook an active campaign during Canadian Book Week. Professor B. K. Sandwell, of Queen's University, gave a largely attended lecture on Canadian literature. Talks on Canadian books were broadcast on the radio. The pupils in the Collegiate Institute were given talks on the same subject, and a campaign was conducted through the press. ("Ottawa Branch Report" 9) 
The Toronto Branch report from the same year is slightly lengthier:

The Toronto Branch received splendid support during Book Week from schools, clubs, booksellers, the press and volunteer speakers. Posters calling attention to Book Week were useful in the store campaign. Doctor [George] Locke arranged for a Canadian window display in McAinsh's store and a special booth at Eaton's. Wembley catalogues of books ${ }^{9}$ were distributed to the Canadian and Empire Clubs; various libraries made displays; also the Boys and Girls house; and the Women's Canadian Press Club had a special meeting at which Dr. Locke spoke.

The private schools were organized with a speaker for each school. Many of the Public Schools and Collegiate Institutes took up Book Week.

The radio was called into service. The Star Broadcasting requested our President, Mrs. John Garvin, to read Canadian lyrics and the Authors' Association was thereby given splendid publicity. ("Toronto Branch Report"13)

This list of events is a fair representation of what the annual week consisted of. Unfortunately, there are no details on which authors spoke at each private school, there is no indication of what the booth at Eaton's contained, or which Canadian lyrics were read over the radio. Local press clippings often do not include much more detail. It is therefore difficult to situate and appraise some of the criticisms of Book Week, such as the Canadian Forum's suggestion that the week employed "violent methods of publicity" and "shock tactics" ("Book Week"). It is also difficult to know whether these events were

\footnotetext{
${ }^{9}$ This most likely refers to a catalogue of Canadian books compiled by the C.A.A. in 1924 for the British Empire Exhibition, a colonial exhibition held in Wembley, England in 1924-1925. Two catalogues were compiled, one for the English section and one for the French section.
} 
used to promote all Canadian authors, as the C.A.A. claimed, or if they simply supported the works of C.A.A. members. To complicate matters, booksellers took advantage of Canadian Book Week — as the C.A.A. encouraged them to do- to advertise the books by Canadian authors that they had for sale. While these advertisements offer a partial list of some of the Canadian authors being promoted during Book Week, it is unlikely that the C.A.A. had control over which authors were promoted this way. So while the C.A.A. implemented, promoted, and attempted to control Book Week, most likely primarily supporting its own members, it appears that Book Week was such a multifaceted event that it would have benefitted all Canadian authors to some degree.

\section{"Indiscriminately Mingling"}

Canadian Book Week was first publicly discussed less than a month after the association's formation, at a dinner hosted by the Board of Trade in Toronto on April 8, 1921. About twenty-five publishers gathered to hear addresses from John Murray Gibbon, the first president of the C.A.A., and Frederick G. Melcher, editor of the American trade-journal Publisher's Weekly. ${ }^{10}$ From this first meeting, Canadian Book Week was about ensuring that writers had a more active role in the Canadian literary marketplace - a role that included promoting their works and promoting themselves as authors. Gibbon spoke of the need for "a new kind of co-operation between author, publisher, and bookseller" (Appleton 46). He suggested that this was a new development in the Canadian literary marketplace, and that the newly active authorial role, as

\footnotetext{
10 "Mr. Melcher had been invited to Toronto as guest of the Association to tell of the experience in the States of encouraging book distribution thru such campaigns as Children's Book Week, Year Round Bookselling, and Religious Book Week” (“Canadian Publishers Meet” 1180).
} 
envisioned by Gibbon, required co-operation among all parties in the book trade.

Supporters of Canadian Book Week echoed this idea of "co-operation" frequently in the first years of the event. John McClelland, of McClelland and Stewart publishing, for example, states "Publishers, authors and booksellers are all interested in the one thing.... All three are inseparably linked up" (qtd. in "Publishers-Authors" 40). Hugh Eayrs, speaking about Book Week, extends this co-operation to include the reader: "There are four intermediaries in the author-reader transfer. There are the writer, the publisher, the bookseller and the public. Co-operation between the first of these, recently evident, is a welcome sign" (263). These comments demonstrate that the C.A.A. appreciated the role writers had in what Robert Darnton later called the communication circuit (68) and that Book Week was an explicit attempt on behalf of authors to change or influence the communication circuit by becoming active participants within it. Canadian writers were not satisfied with their role in Canadian society, and actively sought out ways to change it. This was the real motivation behind Canadian Book Week. This camaraderie between authors and publishers sharply contrasts the rhetoric both groups used to describe each other during the copyright debates — which were, importantly, occurring at the same time. During Book Week, authors and publishers appear to have been able to put their differences over copyright aside, because for this initiative they shared the same goalselling more books.

In the early years of Book Week, the aspect of the event that received some of the harshest criticism was the idea that authors were not sticking to their "proper roles." The question of what does and does not constitute a "proper" role for a Canadian author begins to take shape in a 1921 editorial that appeared in the Canadian Forum: 
The [Canadian Authors] Association came into existence quite legitimately as a union of authors whose legal rights it will henceforth protect. It took a vigorous and timely stand on the question of copyright and earned the approval of all who cared for healthy conditions in the book trade. Its next appearance [Canadian Book Week] was in a new rôle which in practice amounted to publicity and nothing else. This did not seem wholly compatible with the former attitude of the Association and set many wondering what its exact limits were and to what end its main energies would be applied. We all recognise the several rights of publisher, author, and critic, but we are apprehensive when we see them indiscriminately mingled, as they appear to be in the Authors Association.... Methods of publicity which by the general standards of our age are acceptable in the publisher come with an ill grace from the author.... A Book Week belongs to the legitimate sphere of the publisher, hardly to that of the Authors Association. ("Publishers and Authors" 452-3)

For the editors of the Forum, it appears that Canadian authors unionizing to protect their legal rights is "legitimate," but what Gibbon views as "co-operation" in the communication circuit, the editors of the Forum view as separate roles becoming "indiscriminately mingled." 11 The editors of the Forum were not alone in this critique. Barker Fairley notes that the C.A.A. "has confused its own interests with those of the publishers in a manner which in the long run is detrimental to both" (461). T. M. Vesey notes "The author ... has no right to be concerned at all with commercial vindication, or

\footnotetext{
${ }^{11}$ In this quotation it is possible to see the anxiety felt by the editors at the Canadian Forum to the idea that authors would take advantage of aspects of the fastly developing commercialized market, such as "methods of publicity" that are acceptable for the publisher but not authors. Heather Murray has identified this encounter "in which the 'high art' values of literary singularity come into a contradictory encounter with new and expanded systems of production and distribution" (177) as a defining feature of the middlebrow.
} 
even to look for moral support to the adage that the laborer is worthy of his hire" ("Canadian Literature" 91). An editor at the Manitoba Free Press suggests the idea of the then president of the C.A.A., Robert Stead, that literature "is a commodity, an 'article' produced in competition with 'the foreign-made article,' is simply grotesque" ("Mr. Stead's Theory" 8). In taking these critiques as a whole, it appears that the C.A.A.'s decision to create a national book-buying event- the decision by writers to view themselves as labourers in a marketplace, and to promote their own work — was viewed by many as vulgar. It is important to note that criticism appeared in a variety of periodicals and newspapers, even the Bookman, which was briefly affiliated with, and supported, the C.A.A. This "grotesque" desire by Canadian writers to step outside of their normative roles was seen as crass, even by their supporters. This view was not limited to the 1920s. In her 1980 article examining the C.A.A., Mary Vipond echoes it when she writes:

Even the regular members of the C.A.A., however, believed that there must be much more to the organization than simply the protection of professional interests, and this point of view gained the upper hand as the proportion of associate members increased. As early as the first years of the Association's existence, members began to urge that it adopt as a second task the general encouragement and promotion of Canadian literature. ... and soon boosting Canadian books began to take up more and more of the Association's time. (70-1) For Vipond, there is a clear divide between the role of "protection of professional interests" and the "encouragement and promotion of Canadian literature." She suggests that one is acceptable, while the other is not (implied by her use of the word "boosting"). 
For members of the C.A.A., however, these two activities were not disconnected, but were intricately linked. The C.A.A.'s insistence on connecting authors and the marketplace was an essential component of how it understood authorship, and as a result, was heavily attacked by critics, especially modernist writers, who felt that literature necessarily meant disavowing all market considerations.

\section{Author: Muse-inspired Genius or Labourer?}

"We cannot all be limousines on the trail of literature, but the little Ford must not be despised."

- Robert Stead

It appears that the most prevalent view of the role of the author, at least among critics of the C.A.A.'s approach to Book Week, was of the author as a muse-inspired genius. Such a view of the author explains the outrage at the C.A.A.'s desire for authors to be actively involved in the literary marketplace - "true" literature, the work of a genius, will exist, regardless of market conditions, and to worry about such mundane affairs is to sully both the author and her work. In discussions in the literary world of 1920s Canada, these differing views of authorship were never explicitly addressed as such, but they exist implicitly in discussions of the "proper" role of literature. One of these discussions concerned the idea that Canadian literature needed to "walk before it could run"-that is, that Canada needed its own literature, even if it was "poor" literature, before it could sustain "good" literature. In essence, this was a debate about highbrow and middlebrow 
literature. But it was also a discussion of market conditions - Canadian publishers could not simply publish the occasional work of genius. One of the best examples of this debate took place in 1924 between Robert Stead, ${ }^{12}$ president of the C.A.A. in 1923, and the Manitoba Free Press. ${ }^{13}$

In his presidential address at the C.A.A.'s annual convention, Stead explicitly voiced "a mild protest against that school of criticism which demands that we run before we walk" ("Have We" 8). Stead explains that a few weeks earlier, in another address, he had made the "reasonable claim" that "Canadian literature was, on the average as good as the literature which is being imported into Canada" (8). This claim was criticized, Stead says, by critics who "complained that Canadian literature must not be merely as good as the average of other lands; it must be better, before Canadians can be expected to accept it in competition with the foreign-made article" (8). ${ }^{14}$ To this criticism, Stead replies: I am not aware of any other channel of endeavor in which it is demanded of a Canadian that he must produce something not merely as good but better than the

\footnotetext{
${ }^{12}$ Robert Stead was a successful author. Writing fiction predominantly set in the West, Stead's best enduring work is Grain, published in 1926. His fame in the 1920s, however, came from his earlier novels, which were best-selling romances. Clarence Karr notes "The Cow Puncher was Stead's most successful novel in commercial terms. Of all his fiction, this novel most closely resembles the adventure action story in a western, non-agrarian, wilderness setting that was such a popular genre with readers" (104). These middlebrow novels, which supported Stead financially, have been long since eliminated from the canon. ${ }^{13}$ On August 4, 1924, the Manitoba Free Press (MFP) published, in its literary section, an excerpt of Robert Stead's presidential address from the C.A.A.'s annual convention. On the same page, the MFP printed an editorial in response. On October 6, 1924, a response by Stead to this editorial was printed in $M R P$ 's literary section. An MFP editorial also appears on the same page, responding to this letter. The C.A.A. attempted to outline both sides of the debate in its publication The Author's Bulletin (Vol. 2.2), to which the MFP took offense, and issued a clarification of its position in their literary section on January 5 , 1925. The C.A.A. responded in the next issue of the Author's Bulletin (Vol. 2.3). The Stead/MFP debate was apparently discussed widely across the country. An editorial in the Globe from December 4, 1924, notes "The recent discussion between Robert Stead, former President of the Canadian Authors' Association, and The Manitoba Free Press has attracted wide notice" ("Canadian Literature").

${ }^{14}$ Two years earlier, T. M. Vesey wrote an editorial, published in the Manitoba Free Press, which echoes this criticism: "Canada's best chance of achieving a national literature is to reach the frontierless standard that has already been set, not to boost the home-made article simply because it is home-made. We can justly be proud of it when it is as good as, or better than, the foreign-made product - not before" ("Literature-Cult or Commodity?"). This suggests that this debate had been developing for a number of years.
} 
foreign article before he can hope for recognition in his own country. We must walk before we run, and how shall we learn to run if our critics will not let us walk? (8)

In this rebuttal, Stead is engaging in a discussion of the aesthetic value of literature, but more importantly, he is explicitly addressing literature as a commodity affected by market conditions. In this debate, Stead envisions authors as producers of a commodity, labourers who deserve fair treatment in the marketplace. In his response, Stead is acknowledging two slightly different arguments about literature — aesthetic (what type of literature should be printed) and economic (what impact does the marketplace have on the sale of books). The Manitoba Free Press, however, is only concerned with the former:

Literature, being one of the arts, is condemned to come into the world on wings, not even running, but flying, and Mr. Stead's idea that it is a commodity, an "article" produced in competition with "the foreign-made article," is simply grotesque. Literature either is or is not; it springs not from the mere labor of production, but from the gifted or inspired mind: and Mr. Stead's fallacy—a very persistent one - originates in the weird idea that a person, by taking thought and pains, can produce literature. How splendid that would be if it were so. Industry may produce a book; it may produce a thousand, but not literature; literature comes from beyond the gate of horn, and to that exclusive door only the favorites of the nine nymphs possess the key, and no man or woman, however strong-fisted and pertinacious, can beat their way in. ("Mr. Stead's Theory" 8) 
This lengthy quotation demonstrates that for the literary editor of the $M F P$, "literature" exists above the realm of the marketplace and resides solely in the minds of museinspired geniuses, and to suggest otherwise is to sully art. The writer of this editorial assures his readers that "it is not a scarcity of industry we suffer from, but a scarcity of inspiration" and that if we can simply endeavor to light "the fires of our national genius ... the problem of 'Canadian literature' could be left to take care of itself' (8). The writer does not, however, provide any suggestion as to how Canada should go about lighting these fires. It should be noted, however, that this literary editor was not alone in this belief. When the Arts and Letters Club of Toronto compiled a list of all art produced in Canada during 1913, Marjory MacMurphy complained of a lack of genius in Canadian literature, noting "The truth seems to be that Canadians have little gift for writing fiction. ... Canadian fiction for 1913 is interesting because it is native, and at least worthy in character if not inspired by the gods who send genius" (55-56).

As the debate between Stead and the literary editor of MFP continued through the various rebuttals, it became evident, even to those involved, that they were not using the same definition of "literature." As Stead notes in his first response,

[it is] clear that I used the word literature in a quite different sense from that in which it was used by my critic ... The first definition of the word literature given by the New Century dictionary is, "The written or printed productions of the human mind collectively." That is the sense in which I used the word in my address ... that is the sense in which it is used by ninety per cent of the public ninety per cent of the time ... The New Century dictionary, however, goes on to define literature in some of its special sense, and adds: "Literature, in its 
narrowest and strictest sense, belongs to the sphere of high art." This is, obviously, the sense in which the word is used in your editorial. ("Mr. Stead's Theory: A Reply" 5)

Because neither would accept the opposing definition of "literature," the argument continued for several months. This dedication to clarifying their respective positions emphasizes what they each felt was at stake. For Stead, the MFP critic's view on literature - that only the work of geniuses is worthy of consideration - is one of the major reasons that Canadian literature is not more successful: "[This view] has created the impression that there is no 'written or printed production of the human (Canadian) mind collectively,' which is worthy of being read, with the result that the Canadian public turns for its literary diet [towards the United States]" ("Mr. Stead's Theory: A Reply" 5). Stead makes the point that before Canadian literature can be worthy of serious discussion, "a twiddling of thumbs and an incantation of hackneyed formulae while we wait for Providence to send a literary genius for the salvation of a people" only worsens the problem - "a problem so insidious and so complex that if not solved it will eventually threaten our national existence" (5). As Stead notes, Is it, therefore, surprising that a million American periodicals are sold in Canada every issue, and that the cheaper class of fiction is imported into the country by the carload? It may be that you will contend that this is not literature at all, but it is what the Canadian public is consuming in place of literature; for many thousands of them it is all the literary diet they have, and it is gradually introducing into this country a foreign sentiment which may have consequences so far-reaching that they are not pleasant to contemplate. Meanwhile our critics 
point to Keats and Carlyle, and bid us hold our peace in anticipation of a literary immaculate conception! (5)

Stead insists on considering what the reading public is actually "consuming" in their reading habits.

In response, the MFP ignores the problem, outlined by Stead, and argues instead that he has missed the whole question entirely, which is "Why is Canada Not Producing a Literature?" The author of the article points to the past, arguing that Canada used to have authors who produced literature, and wonders why this is no longer the case:

Mr. Stead's excuse for the feeble work of today is not a new one. It is unreasonable, he says, to expect Canada to run before she can walk; to produce a literature before she has had the necessary experience and training. This is an excuse which does not meet the facts at all. The point is, that twenty-five years ago, and earlier, Canada was producing a literature. (emphasis in original, “Canada's Literary Movement" 5)

The objection, expressed here, that Canada was not producing literature is not simply connected to the fact that Canadians were not writing and reading Canadian novels, it is that when they did read Canadian novels, they were reading the wrong type of literature - namely, middlebrow. There was an anxiety among the literary elite over the rise of best-selling fiction that began in earnest in the 1920 s, with L. M. Montgomery as a perfect example. As Faye Hammill points out, these middlebrow books were viewed negatively because of their success in the marketplace, and because "the middlebrow ... [has] been persistently gendered feminine, with a belittling and exclusionary intention" (6). The author of the MFP article pines nostalgically for the past, before the technology 
and market allowed for such best-sellers - a time when Canada was producing "literature." The author suggests three Canadian authors as examples: William Kirby, Isabella Valancy Crawford, and Edward William Thomson. All three of these authors, while beginning to be canonized in the 1920s, had experienced difficulties with the Canadian marketplace. In other words, the retrospective validation of these authors is one based on canonization as opposed to sales. The temporal distance between the critic and the authors allows the question of an author's monetary reimbursement to be safely ignored. So while their "genius" allowed their work to survive, they did not benefit from their labour as authors. This, it seems, is the crux of the debate: for the C.A.A., this situation is no longer desirable, or acceptable, while for the critics of the C.A.A. it is simply the proper way. Yet, while refusing to discuss the practical problem of book publishing in Canada, this critic still wonders why "Our writers are as sedate as nuns; not an adventurer anywhere riding out and breaking a lance just for the thrill of the joust and because life moves in him with some exuberance" ("Canada's Literary Movement" 5). He critiques Stead for "drumming for our literary pedestrians" (5).

This accusation that Stead's view of literature as a commodity in the marketplace results in "drumming for our literary pedestrians" is noteworthy because of how the critic equates Stead's view on the marketplace with a corresponding aesthetic view on literature. In other words, since Stead wants to support all authors as labourers, he must, as a logical conclusion, be supporting (and promoting through Book Week) bad literature. By making this connection, Stead's critic is then able to attack Stead's perceived literary taste, without seriously engaging in a discussion of the role of author in the literary marketplace; Stead's taste operates as a convenient distraction from the material issues. 
The MFP editor's view on the marketplace is dictated by his view of literature. While Stead may agree that the best literature is the work of inspired geniuses, that does not mean he does not also think that there is reason to foster the marketplace for writing of all kinds. Stead's view of literature in this debate, therefore, is based on the practical concerns of the marketplace, and not on any notion of literature as something that transcends its circulation. While Stead is presumably speaking on behalf of the C.A.A. during this debate, it should be remembered that Stead himself was an incredibly successful author of popular fiction, which most likely would affect his view on "literature." This concern with the marketplace over a more traditional understanding of literature was fairly ubiquitous within the C.A.A. in the early 1920s.

Soon after the C.A.A.'s formation, the Canadian Forum pointed out a potential problem with the C.A.A.'s first object, as stated in its constitution, which is "To act for the mutual benefit and protection of the interests of Canadian Authors and for the maintenance of high ideals and practice in the literary profession" ("Authorship and Copyright" 230). As the Canadian Forum points out, "there are two objects here, not one, and they very often conflict with one another. The one calls for vigorous self-protection and the other for vigorous self-criticism which is much more difficult" ("Authorship and Copyright" 230). This prediction, arguably, became true, as the C.A.A. devoted its attention to the former, while abandoning the latter, at least in the 1920s. This abandonment of "vigorous self-criticism," in lieu of self-protection, helped earn the C.A.A. a reputation for supporting "traditional" and "Victorian" books, as the Stead debates demonstrate. The C.A.A. of the 1920s, however, never explicitly supported any one Canadian text over another. That is, I have found no material published by the 
C.A.A. during Book Week, or at any other time, that explicitly states that readers should buy books by a specific Canadian author. Booksellers often ran advertisements during Book Week which promoted specific Canadian authors, but it is unlikely that these advertisments were controlled by the C.A.A. Instead, the C.A.A. claimed to support all Canadian books. ${ }^{15}$ But by not explicitly advocating specific standards-i.e. not supporting only "good" books - it was seen as supporting "bad" books, encompassing both books of inferior literary quality as well as books that were seen as too traditional.

Before the beginning of the second annual Book Week, B.K. Sandwell addressed the "two arguments which have been most insistently urged against the Week." These were, "first, that it is 'undignified'; and, second, that it is a demand upon the Canadian public to read bad Canadian literature as much as good” (“Another Book Week" 155). The first criticism, that Book Week was undignified, was another charge against the C.A.A. for encouraging authors to step outside their "proper" authorial roles. Sandwell, unsurprisingly, defends the C.A.A.:

We have found it practically impossible to get any of the critics of the Week to put their finger on any specific act or series of acts performed by the Association or its members in connection with the Week which can be described as undignified, unless we are willing to admit (which we are not) that the very conjunction of the Association with the organization of the Canadian publishers is undignified. (“Another Book Week” 155)

\footnotetext{
${ }^{15}$ The one exception to this was the C.A.A.'s literal crowning (with a laurel wreath made of maple leaves) of Bliss Carman as Canada's Poet Laureate. While this stunt may be seen as an endorsement by the C.A.A. of Carman and his poetry, the real reason for the crowning was far more practical—publicity. Margaret McWilliams, president of the Winnipeg Women's Canadian Club had arranged a poetry reading tour for Carman through the West, but was afraid that the poet was not well enough known. She turned to John Gibbon, president of the C.A.A., and asked for help in promoting the tour, and so a Poet Laureate was crowned.
} 
Sandwell defends the co-operation between authors and publishers that the C.A.A. encouraged, and scoffs at the idea that it is in any way "undignified." Sandwell's response to the second charge is worth quoting at length:

As regards the charge of indiscriminateness, we cannot too earnestly repeat that it is not and cannot be the function of the Canadian Authors Association to instruct the Canadian public in discriminating between good and less good Canadian literature. The Association is not an Academy, and has neither the power nor the facilities nor the desire to pass judgment on the literary merits of any Canadian writer, be he in or out of its membership. Throughout its propaganda last year it laid constant emphasis on the need for good judgment by the Canadian public in the selection of Canadian books; but the formation of that judgment is not one of the Association's functions. It cannot collect an annual fee from Brown, Jones and Robinson, all three Canadian authors, for the purpose of telling the public that Jones is a better literary artist than Brown, but not so good a one as Robinson. ... The Association is not a private literary club: it is an organization which aims to represent the interests, and so far as possible to include the persons, of the whole body of writers engaged in practising the profession of letters. It is for the critics, the public and posterity to decide which of them is "good" authors and which are not. (“Another Book Week” 156)

Sandwell is trying to make a distinction between two separate professions. On the one hand, there is the C.A.A., which is a professional organization of writers whose job is to write literature, and, on the other hand, there are professional critics (reviewers, professors, et cetera) whose job is to critique literature. This statement by Sandwell, then, 
is an explicit rejection of the latter half of the C.A.A.'s first objective, to act "for the maintenance of high ideals and practice in the literary profession," as the Forum pointed out. The justification of this rejection, however, is unique in that it is one of the few instances where the C.A.A. did not attempt to avoid the accusation. The typical modus operandi for the C.A.A. when criticized for supporting bad literature was to become defensive and assure the public that it supported the best literature. In Sandwell's statement here, however, we get a very different reaction. Sandwell states simply that the C.A.A. does not, and cannot, serve any function in discriminating between good and "less good" Canadian books, precisely because it seeks to represent all Canadian authors, as workers; it sees itself as a union, not the Academy.

\section{Book Week: Just Another Name for "Materialistic Patriotism"?}

Aside from the criticism that the event encouraged Canadian book buyers to purchase "bad" Canadian books over better quality literature, the largest criticism the C.A.A. faced was that the event was overtly patriotic. This charge was often made in conjunction with an attack against the C.A.A. for supporting "bad" literature, because supporting Canadian literature necessarily meant ignoring great works of literature from other countries. In other words, the C.A.A. was seen as being anti-cosmopolitan. While the C.A.A. occasionally attempted to defend itself from this charge, it was difficult-its mission, after all, was to protect and promote Canadian authors. Alongside this agenda, the C.A.A. appears to have genuinely believed that reading Canadian literature was essential to the development of a unique Canadian identity and consciousness. These two ideas 
often dovetailed, probably to make the former more palatable to the Canadian public. This convergence is evident in Stead's "Literature as a National Asset," a radiographed address to open Book Week in 1923. He states:

In the material world we, as a matter of national policy, have given protection to our infant industries against the competition of other nations. No such protection is given Canadian literature, although in the final analysis, it is immensely more important to the future of Canada that we should make our own songs and our own stories than that we should make our own automobiles and our own repairing machines. The Canadian Authors stand ready to give that service, and ask, not fiscal protection, but merely a sympathetic hearing by their own people. They ask that they be not crowded out at the book stores and the news-stands and the public eye and imagination by the highly organized competitive literature of other nations, which, no matter how attractive or entertaining it may be, contributes nothing to Canadian life and Canadian tradition. (343)

Stead continues to use the rhetoric of the marketplace to discuss literature, even comparing it to commodities such as automobiles and repairing machines. Literature is an "infant industry" which needs, if not federal protection, at least a "sympathetic hearing" because it is the most important industry, as it is the industry that lets Canadians learn about themselves. Buying Canadian books, then, not only helps Canadian authors, but it also benefits the nation at large - it becomes a patriotic duty.

This patriotic appeal must have been successful, or at least well vocalized, as by the late 1920s the C.A.A.'s patriotism became one of the focuses for the Canadian modernists' now well-anthologized attacks. For example, F. R. Scott's 1927 poem, “The 
Canadian Authors Meet," famously epitomizes the modernists' distaste for the C.A.A.'s patriotism with the lines: "O Canada, O Canada, $\mathrm{O}$ can / A day go by without new authors springing / To paint the native lily" (21-23). ${ }^{16}$ Likewise, in 1928, A.J.M. Smith attacked this patriotic sensibility in his article "Wanted — Canadian Criticism," in which he notes: "[The nature of the "Canadian-consciousness"], judging from its most characteristic forms of expression, is a mixture of blind optimism and materialistic patriotism, a kind of my-mother-drunk-or-sober complex ${ }^{17}$ that operates most efficiently in the world of affairs and finds its ideal action summarized in the slogan 'Buy Made in Canada Goods" (600). Smith continues by noting that "There is, perhaps, something to be said for this state of mind if cultivated within certain very definite limits, if it be regarded solely as a business proposition and with due regard for economic laws; but when duty and morality are brought in and the above mercantile maxim is held to apply to things of the mind and spirit: that is an altogether different matter" (600). Smith echoes earlier critics' accusations that the C.A.A. is mixing the "mercantile" with the "things of the mind and spirit" (i.e. literature), but adds that it is even worse to resort to "duty and morality." In short, "The confusion is between commerce and art" (Smith 600). This confusion is a problem for Canadian authors, Smith argues, because the C.A.A.'s patriotic appeal for Canadian citizens to buy Canadian books has been so successful that the Canadian author is often forced to compromise his integrity: "If he chooses to work

\footnotetext{
${ }^{16}$ In subsequent printings of this poem, Scott changes the word "lily" to the more appropriately Canadian "maple," although losing the Shakespearean reference in the process.

${ }^{17}$ This now rarely used idiom comes from the work of English author Gilbert Keith Chesterton. In his essay, "A Defence of Patriotism," Chesterton writes:

"'My country, right or wrong,' is a thing that no patriot would think of saying except in a desperate case. It is like saying, 'My mother, drunk or sober.' No doubt if a decent man's mother took to drink he would share her troubles to the last; but to talk as if he would be in a state of gay indifference as to whether his mother took to drink or not is certainly not the language of men who know the great mystery." (166)
} 
out his own salvation along lines which cannot be in keeping with the prevailing spirit of pep and optimism he finds himself without an audience, or at least without an audience that will support him" (600). This compromise, Smith argues, is the temptation of "the devil," to which "the whole communion of [the C.A.A.] has succumbed in a body." To Smith's dismay, he argues that "So far, it is true, literature as an art has fought a losing battle with commerce." In 1928,

If you write, apparently, of the far north and the wild west and the picturesque east, seasoning well with allusions to the canada goose, fir trees, maple leaves, snowshoes, northern lights, etc., the public grasp the fact that you are a canadian poet, whose works are to be bought from the same patriotic motive that prompts the purchaser of Eddy's matches or a Massey-Harris farm implement, and read along with Ralph Connor and Eaton's catalogue. (600)

While Smith, along with his fellow modernists, is concerned that literature in Canada is considered equivalent to other Canadian-made products, this lamentation demonstrates, to some extent, how successful the C.A.A.'s propaganda during Book Week truly was. Smith notes, however, that the "the campaign [between art and commerce] as a whole has barely begun" (600). The modernists would have the final word, with their critiques against the C.A.A., such as Scott's and Smith's, standing in as the legacy of the C.A.A. in Canadian literary history. ${ }^{18}$ Regardless of whether one agrees with the C.A.A. or the modernists, this history of the C.A.A. as being blindly patriotic disregards the reasons why Book Week was established in the first place — to provide authors with direct

\footnotetext{
${ }^{18}$ Those running the C.A.A. are clearly still upset about this legacy. In its self-published history Syllables of Recorded Time (1981), Lyn Harrington notes that "Scott and others of the Montreal Group were bright, impatient, idealistic, scornful young men, sniggering at their seniors' earnest endeavours. Their satire was cruel and biting and so funny to their undergraduate peers" (71).
} 
intervention in the marketplace. While commonplace in the twenty-first century, the C.A.A. faced constant critique over the suggestion that books were commodities, and the changing notion of the role of the author that this demanded.

\section{Conclusion}

The first five years after the establishment of the C.A.A. was a busy time for the young association. Not only was it establishing local branches around the country to gather Canadian authors together, but it was also lobbying the federal government for substantial changes to the Copyright Act, while organizing and running an annual book buying event. On the surface, these two activities appear to be concerned with different aspects of the literary marketplace. Lobbying the government was concerned with the

political, an attempt to guarantee legal rights through copyright reform, while Book Week was mostly concerned with the economic and social, an attempt to change the buying and reading habits of Canadian citizens. Importantly, however, both of these activities generated public debate around the issue of the role of the author. In both of these debates, the C.A.A. promoted the author as a labourer, as opposed to the romantic notion of the muse-inspired genius. The relation of this author-labourer to other labourers in the book trade, however, appears to be fluid, with the C.A.A. taking on quite contradictory positions in relation to these respective debates. Importantly, it should be noted that these two debates were occurring simultaneously—a number of issues of the Canadian Bookman and the Author's Bulletin contain articles on copyright reform and Book week, which appear alongside each other. This suggests that for the C.A.A. this confusing 
hierarchical positioning of the author-labourer in relation to other labourers was not purposeful obfuscation. Instead, it seems that the attempt by the C.A.A. to assign authors a single role was still a work in progress. 


\section{Chapter Two: The Governor General's Literary Awards}

A pivotal moment in the history of the Canadian Authors Association took place in 1935 when John Buchan, later to become Lord Tweedsmuir, became Governor General of Canada. Although Buchan was a politician, he was far better known as a writer; he was a literary celebrity, having written dozens of popular adventure novels, including The Thirty-Nine Steps. The C.A.A. took great pride in Buchan's appointment. On the cover of the March 1935 issue of Canadian Author the C.A.A. published the announcement, noting that

Canadians of every sort, with spontaneous unanimity, are expressing high approval of our new Viceroy, John Buchan: but to none can his appointment give quite the same special warmth of satisfaction it gives his fellow-craftsmen.

It will be particularly agreeable to see the King represented at Ottawa by one not only of such high public capacity and so attractive a personality, but distinguished also as "a first-class writing man.” ("Modern Viceroy”)

The C.A.A. sent a congratulatory note to Buchan, and asked if he would accept the honour of becoming the association's first Honorary President. ${ }^{1}$ He accepted, and in the Canadian Author, Pelham Edgar, President of the C.A.A., stated that "it is our purpose to convince him that he has associated himself with an organisation that is capable of doing most valuable service to our country's literature" ("From the President" 2).

While Buchan's agreement to become the C.A.A.'s Honorary President may seem like a small token of support, without any actual commitment on the Governor General's

\footnotetext{
${ }^{1}$ The honour came with no real responsibilities, although the C.A.A. did ask Buchan to speak at a few events after his appointment.
} 
behalf, I would argue that it provided the C.A.A. with essential symbolic capital. Buchan was a British literary celebrity. Nowhere is this made clearer than in a newspaper article published in the Globe on December 27, 1935, entitled "John Buchan Buys a Book." This article is exemplary of the type of paparazzi-driven media stories to which we have become accustomed. The article recounts a simple story: the Governor General purchased a book. The clerk in the bookstore, however, neither knew immediately whom he was waiting on, nor would he reveal the title of the book bought. Nonetheless, the event was newsworthy because "when the present Governor-General of Canada goes shopping in a bookstore, the clerk who waits on him has a rare opportunity of giving the world a bit of interesting news" (emphasis added, 4). This lack-of-news-story is newsworthy, therefore, because of who Buchan is:

No doubt, like most men, the Governor-General leaves this general Christmas business to the woman folk; but, being a master literary craftsman himself, he selects his own books. Many an admirer of John Buchan will envy that clerk. He would like to observe a great maker of books examine, with a view to purchase, a volume turned out by another writer. Only real book-lovers know how to handle a book anyway; they realize the work - the enjoyment, or perhaps the hours of anguish—devoted to its production. (4)

It is perceived by the public that, Buchan, as a "master literary craftsman," is able to appreciate books appropriately. His role as an authority on books, conflated with his masculinity (the task of choosing a book is something he could not leave "to the woman folk"), provides Buchan with the literary legitimacy necessary to consecrate the work of a fellow author, simply by buying her or his book. Buchan, as a bourgeois producer of art, 
with both the economic, social and political capital that this provides, has the power "to say with authority who are authorized to call themselves writers" (Bourdieu, Field 42) and, by agreeing to become its Honorary President, Buchan has consecrated the C.A.A. with this authority. This consecration of the C.A.A. comes from both within the literary field, through John Buchan as author, but it also comes from outside the literary field. Buchan's position as Governor General places him in the field of power; as the representative of the British monarch in Canada, Buchan's consecration of the C.A.A. is imbued with the authority and tradition of royalty. The C.A.A. is unable to be an autonomous producer of art within the literary field, as its consecration is reliant upon the field of power.

In Bourdieu's terminology, all cultural commodities produced within a specific field can be placed along a spectrum, according to the logic of that field. One end of the spectrum contains works that adhere to the heteronomous pole, and are deemed successful by forces predominantly outside the literary field. The success of these works is "measured by indices such as book sales, number of theatrical performances, etc. or honours, appointments, etc." (Field 38); in other words, they are works that achieve financial success in the marketplace, and accrue economic capital. The other end of the spectrum contains works that are autonomous, and are deemed successful solely by logic specific to the field. The most autonomous works reject the logic of the marketplace, and are produced solely for the appreciation of other producers of art, i.e. "art for art's sake." In rejecting the marketplace, and as a result, economic capital, autonomous works of art accrue cultural capital. In short, all cultural commodities fall on a spectrum, with works that aim to be bought by consumers (heteronomous) on one end and works that are meant 
to be appreciated only by a small elite (autonomous) on the other. As Bourdieu notes, "The literary ... field is at all times the site of struggle between the[se] two principles of hierarchization" (Field 40).

As Nick Mount argues, Canadian literature at the beginning of the twentieth century did not belong to its own literary field, but belonged to the much larger literary field of North American literature, dominated by American publishing houses. As a result, Canadian authors who wanted to accrue economic capital-i.e. attempt to make a living as an author — had to move to either the publishing centres of New York or London. In Bourdieu's terminology, Canadian authors who stayed in Canada and wrote Canadian literature were moving towards the autonomous pole. This is not to suggest that there was not both highbrow and lowbrow art being produced in Canada, because there was. Instead, when viewed within the larger literary field of North America, writing and printing literature in Canada was often done against the logic of the market. These authors were moving towards the autonomous pole because they rejected the heteronomous principles that governed the larger American literary field. These works of Canadian literature were geared towards a small audience, almost exclusively other producers of Canadian art. These works were often praised simply because they were Canadian, and while they did not accrue economic capital, they did accrue cultural capital for their Canadian content. The creation of the C.A.A. was, in part, an acknowledgement that a uniquely Canadian literary field existed, separate from a North American literary field, which would be governed by its own set of rules.

Bourdieu argues that a literary field is composed of competing capital which "represents a power of the field" ("Society" 724). Relevant to this chapter are his 
concepts of cultural and social capital. For Bourdieu, cultural capital is a form of noneconomic capital that manifests itself in knowledge, skills, education and other advantages that an individual possesses. This form of capital can exist in an embodied state, such as a person's ability to speak several languages. It can, however, also exist in an institutionalized state. Bourdieu describes this institutionalized cultural capital as usually being objectified in "in the form of academic qualifications" ("Forms" 247). As such, a university bestows institutionalized cultural capital on a student in the form of diploma. Similarly, the C.A.A.'s Governor General's Literary Awards bestow the winning authors with institutionalized cultural capital, which can be converted into economic capital in a variety of ways, such as through the increase in the sale of their books, or in securing a future publishing contract. As Bourdieu notes, "one sees clearly the performative magic of the power of instituting, the power to show forth and secure belief or, in a word, to impose recognition" (248). It is this power-to recognize some authors, and not others - that the C.A.A. held through its literary award system. Bourdieu refers to this power of recognition — to define, limit, and determine what art is "good" and which art is "bad" - as symbolic capital. The C.A.A.'s success in using the GG awards to impose its view of literature is determined by its symbolic capital in the literary field at the time.

Alongside Bourdieu's framing of the literary field and its various forms of capital, it is useful to consider Gillian Roberts's examination of contemporary literary prizes in Canada, as she argues that prize culture in Canada has a unique feature which modifies the literary field. Specifically, Roberts argues that "national celebration of Canadian 
cultural products," "project[] a unified habitus on the basis of shared nationhood" (14).

Such a national habitus

rests on what we might consider national capital, rather than the economic, cultural, and academic capitals that are integral to class habitus: a national habitus uses the nation as its currency, emphasizing the value of national cultural products precisely because of their nationality, and attempting to forge a national taste - $\mathrm{a}$ taste for the nation and its culture. (emphasis added, 14)

This valuing of Canadian products, because they are Canadian products, can be seen in many of the C.A.A.'s projects, such as Book Week. As discussed in the previous chapter, this attempt to promote Canadian books simply because they were Canadian was criticized, partly because of the approach — that is, buy any and all Canadian books. This criticism came predominantly from avant-garde poets who were against the heteronomous influence of the marketplace on the literary field. Even when couched in warnings to only buy "good literature," Book Week drew critiques for its lack of quality control. The creation of the Governor General's Literary Awards, as this chapter argues, therefore allowed for the continuation of the C.A.A.'s attempts to promote and craft a specific reading public — what Roberts would identify as a unified national habitus — that valued specifically Canadian literature. At the same time, the association was attempting to avoid criticisms that its decisions were dominated solely by the marketplace, by claiming to select the best piece of literature each year based on literary merit. However, the Governor General's Literary Awards were structured to consider a variety of factors, with its emphasis on "Canadianness" being just one example. 
As Roberts explains, in the attempt to create this national habitus, "the notion of national capital suggests that nationality becomes a kind of currency in the cultural marketplace" (emphasis in original, 21). She continues:

The addition of national capital to the collision of the symbolic and economic reinforces the literary prize's function as a tool of popularization: not only do literary prizes support the consumption of literature in general terms, but in the Canadian context, they also specifically promote the consumption of Canadianness alongside the idea that Canadian culture can profitably trade in the currencies of both symbolic and economic capital. ... Canadian literary prizes thereby attempt to render the Canadian public more hospitable to Canadian literature. ... In Canada, [literary prizes] all work on some level to win the consent of the Canadian public to the valuing of Canadian literature, and to the idea that CanLit is worthy of celebration. (21)

In this definition of the role of national capital, Roberts encapsulates the various goals of the C.A.A. in both Book Week and the Governor General's Literary Awards: not only to "render the Canadian public more hospitable to Canadian literature," but equally to create the idea of national uniqueness- "Canadianness" - as a form of capital. Canadian books should be valued, in part, because they are Canadian. I agree with Roberts that part of the Canadian literary field, at least in the mid-twentieth century, was a fight for national capital alongside symbolic, economic, and political capital.

Through the copyright fight and Book Week, the C.A.A. attempted to define Canadian authorship. As Bourdieu argues, this is the fundamental issue at stake in the struggle to define any literary field (Field 42). The economic and patriotic goals of 
Canadian Book Week made valorization in the Canadian literary field predominantly heteronomous, i.e. its importance was found outside of the literary field. Thus, the modernists' attacks on the C.A.A. can be explained as the actions of producers of art, who strive to be autonomous, resisting and refusing the definition of Canadian authorship that the C.A.A. was attempting to establish. I would argue that when John Buchan consecrated the C.A.A. by agreeing to become its Honorary President (and supporting many of its endeavors), the association began to win this struggle. By this point in its history, the mid-1930s, the association had an annual membership of over six hundred members, had been consecrated by a well-known British author and one of the biggest literary celebrities in Canada, was being run by prominent men in the literary field (such as William Arthur Deacon), and as a result, arguably had the "monopoly of literary legitimacy" (Bourdieu, Field 42). Having the monopoly of literary legitimacy gave the C.A.A. the power "to say with authority who are authorized to call themselves writers; or, to put it another way, it is the monopoly of the power to consecrate producers or products" (42). The C.A.A. could bestow literary awards upon Canadian authors that would carry the appropriate cultural capital, i.e. the awards would have the power to consecrate the winners. More importantly, however, the C.A.A. could use these awards to influence the type of literature, and the type of literary producers, that would be seen as acceptable.

The Governor General's Literary Awards were the first national literary awards in Canada for English literature. ${ }^{2}$ Since their inception in 1936, the awards have become

\footnotetext{
${ }^{2}$ The first national literary award in Canada was the Concours littéraires du Québec/Quebec Literary Competition established in 1923 by the provincial government of Quebec. Any Canadian citizen could submit entries in French, but English entries were only accepted if the author had been living in Quebec for at least five years (Lonardo et al., "Concours").
} 
known as the most "prestigious" literary awards in Canada. Currently, the Governor General's Awards are viewed as more autonomous than their main competitor, the Scotiabank Giller Prize, whose connection to the marketplace is evident from the sponsorship found within its name, as well as the $\$ 100,000$ cash prize that accompanies the award. While literary prizes are currently viewed as an integral part of the literary field, with different awards consecrating differing degrees of cultural capital dependent on the award's perceived autonomy, this has not always been the case. Prize culture, in Canada at least, was very different from 1936-1960: the GG awards were the only national prize for Canadian literature; they did not come with any financial compensation; despite the name, they had no direct connection to the state, or to state funding; and, perhaps most importantly, they were created fifteen years before the Massey Report unequivocally stated that Canadian literature, as a field, did not yet exist. In other words, the GG awards were awarded to Canadian authors for having produced the best works of Canadian literature, while the very concept of Canadian literature itself was still being heavily interrogated. This chapter argues that the C.A.A. created the GG awards in an attempt to circumvent some of the criticism it faced during the 1920s that it promoted all books regardless of the quality. With the GG awards, the C.A.A. could claim to have some autonomy in the literary field, by choosing the "best" literature of the previous year, based solely on "literary merit." In reality, however, the judging of the Governor General's Literary Awards under the C.A.A.'s control was influenced by a number of complicated and conflicting influences, often from outside the literary field. Although not always successful, the C.A.A.- predominantly through the work of William Arthur Deacon - attempted to influence the GG awards so that they were 
awarded to authors who supported its views of literature. Instead of imposing an increasingly rigid hierarchy over what constituted as literature, as advocated by modernist poets at the time, Deacon wanted to widen the definition, and as a result, championed middlebrow writing, living wages for authors, and a national literary culture. In this cultural moment, prize culture in Canada was being used to support as many working writers as possible, who were producing literature for a wide reading public.

\section{"Raising the quality of our work:" From Copyright to the GG Awards}

The beginning of the 1930s saw the Canadian Authors Association still running a yearly Canadian Book Week, and still lobbying the government for changes to the copyright law. In 1928, the Berne Convention was revised at a month-long gathering in Rome. The two largest changes were the inclusion of moral rights for authors, and motion pictures and radio were added to the list of media that could be copyrighted. As Sara Bannerman notes, "A new bill to amend the Copyright Act was introduced in the House of Commons on 18 March 1931 and received royal assent on 11 June, but only after significant debate. The bill was introduced by the government in order to deal with the issue of performing rights organizations in Canada, and to implement the 1928 revision of the Berne Convention" (121). The C.A.A. was opposed to the new law on a number of grounds. For one, "the law still left Canadian authors . . . subject to the obnoxious licensing clause" (Sandwell, "New Copyright" 36). More importantly, however, the new law granted free use of copyrighted music "to any church, college, or school, or . . . any religious, charitable or fraternal organization" and to "any agricultural exhibition or fair" (qtd. in 
Sandwell, "New Copyright" 36). The C.A.A. felt that these exemptions were "unfair to intellectual labour" and "unwarrantably deprive[d] the composer of music of his due and proper remuneration" (Sandwell, "New Copyright" 36). The C.A.A. passed an amendment at its June 1931 convention to seek changes to this new copyright law at the next session of Parliament.

As Bannerman notes, "Broadcast and performance rights would become very important in Canada in the years to come; two Royal Commissions would be established to deal with the issues" (113). The C.A.A. continued to be active in lobbying for the rights of all of its members, which included musical composers. During this time, C.A.A. President Duncan Campbell Scott reminded association members that "Our Constitution was expressly designed to include, and does include, workers in other arts besides the literary,- - musical composers, painters, illustrators and sculptors, for instance. We welcome them as we welcome writers" (4). During these debates in the 1930s, which were often reminiscent of the copyright debates of the 1920s, "The recurring question concerned how Canada could navigate between the norms of the most powerful members of the Berne Union and those of the United States" (Bannerman 120). Similar to the 1920 s, the authors were not content with the government's solution.

By 1931, the decade-long annual Book Week was beginning to receive an apathetic response, even from members of the association itself: "With a more than doubtful shake of the head a member asks: ‘Are we satisfied with Book Week?' He is not" ("Book Week—Or Else" 2). Alongside this apathy, Book Week still had its critics: "One critic says 'Cut it out."” In response, the C.A.A. urged "those who would abolish 
Book Week . . . to suggest alternatives.” In response to its critics, as well as its dissatisfied members, the C.A.A. suggested:

Let us compare experiences, give up Book Week if any better alternative can be suggested, or improve our methods of celebrating it, and supplement it at other times of the year by any methods of action both legitimate and expedient that our wits can devise.

We cannot rest until our people are thoroughly inoculated with an appetite for reading and discrimination in choosing what they read. ("Book Week-or Else" 2)

This rhetoric, such as having to inoculate - implying that a lack of a desire to read is both a disease, and something that the C.A.A. needs to forcefully do-is reminiscent of earlier Book Week rhetoric, such as the suggestion in 1921 that all methods of promotion would be appropriate including the use of dynamite. Despite the apathy, and continued criticism, the C.A.A. continued to feel a responsibility to encourage reading in Canada. In lieu of the criticism that it faced in the 1920s, the C.A.A. also began an almost annual reminder that Book Week celebrated all literature, not just Canadian literature. In 1931, for example, members were reminded that "In our celebrations [of Book Week] let us make it clear that we want to stimulate interest in good literature as a whole and not only (though on such an occasion with particular emphasis) in our Canadian section of good literature" (emphasis in original, “Canada's Book Week” 40), and in 1932, a similar reminder was sent out, ““'In whatever we do [during Book Week], let us make it clear that our object is to stimulate the reading of good literature, whatever its origin." But, even in this appeal, the C.A.A. undermines its own position by noting: "It is our duty, of course, 
to bring out the fact that many Canadian books rank high among works of the same class in the good literature of the world - for thousands of our fellow-countrymen have not yet realized this fact, and still labour under the delusion that high quality is only to be found in the imported article" ("Book Week Nov. 5-12" 4). As a result, Book Week continued to be dogged by the criticisms it faced during the 1920s.

By 1930, the essential aims of the C.A.A. were beginning to be viewed differently. In the 1920s, the Canadian Forum correctly identified the C.A.A.'s abandonment of the second half of its first principle - " the maintenance of high ideals and practice in the literary profession"- to focus on the first half- to "act for the mutual benefit and protection of the interests of Canadian Authors." The beginning of the 1930s, however, saw an effort to remedy this situation. At the annual convention in 1930, Howard Angus Kennedy reminded the members that "[The association's essential objects] are - both to defend the professional interests of writers and other creative artists, and by raising the quality of our work to make it more and more worthy of defence. The second of these objects is clearly the higher; but the first still needs constant vigilance and strenuous effort" ("National" 7). While this was an appeal for members to continue to support the association's lobbying for copyright, the suggestion that "raising the quality of our work" is the primary objective of the C.A.A. appears to be a reversal of its mandate during the first decade of its existence.

In the 1930s, the C.A.A. did begin a number of initiatives that explicitly praised and promoted some Canadian authors over others, although this was arguably more of an extension of the association's mandate that it set in the 1920s than a rejection of it. In other words, the initiatives that the C.A.A. created in the 1930s did praise the work of 
specific authors, but these initiatives also had a secondary role of promoting Canadian authors, and Canadian literature, as a whole. The three most important initiatives during the 1930s and 1940s for the C.A.A. were all established within a few months of each other during 1935-1936: the establishment of the Association of Canadian Bookmen, the creation of the Canadian Poetry Magazine, and the creation of the Governor General's Literary Awards.

In its annual notice about Book Week for 1935, published in the Canadian Author, the C.A.A. notes that "To achieve the greatest possible success for this movement, the National Executive Committee has decided to open negotiations with the publishers', booksellers' and librarians' organizations, for a joint effort. This cooperation, it is felt, should not be confined to Book Week" ("Book Week-And After" 6). Although both the general public and some members of the C.A.A. were beginning to become apathetic towards Book Week by 1935, the National Executive still insisted on its importance. More importantly, however, as the 1935 announcement makes clear, the C.A.A. was still sincerely committed to co-operation in the book trade. It was this dedication to co-operation — or, more specifically, the dedication to having authors be viewed as legitimate agents in the literary marketplace—-that had spawned Book Week fourteen years earlier. With Book Week becoming less successful, however, the C.A.A. decided that there needed to be a more permanent co-operation. Thus, the C.A.A. contacted the various agents in the book trade, and in November 1935, managed to organize a new association: the Association of Canadian Bookmen (A.C.B.). An optimistic editorial in the December 1935 issue of Canadian Bookman explained the purpose of the new association: 
Rejuvenation and reform of the existent publishing system ... with authors and librarians and booksellers and publishers all joining in aggressive alliance and pooling their brains, seemed . . . likely to succeed.

Could such a greater working-together be hoped for?

The National Executive of the Canadian Authors' Association determined to try. Our initiative was welcomed, and the new Association of Canadian Bookmen is the result.

The Authors' Association, far from giving up one atom of its independence or soft-pedaling any of its claims, will gain greatly by having the whole four-fold strength of the new body to back it up.

... The author's and publisher's interests are identical up to a certain point - a high point. They both want to see the Canadian people become a reading people.

... We know well enough that the publishers' interests, beyond the point mentioned, are not identical with ours. The great majority of the books they list for sale come, naturally enough, from Great Britain and the United States, whether a Canadian firm's name appears on the title-page or not.

Most of our publishers however are themselves Canadians and would personally be glad to see Canadian books take the high position they ought to hold in their own country. . . .

On both national and commercial grounds, therefore, the publishers and booksellers forming the trade wing of the alliance have agreed that the advancement of Canadian literature must be a specially prominent feature of the 
new association's programme. (emphasis in original, "Something's Going to be Done" 4-5)

Although there were fears that the C.A.A. would lose some power as a result of this new association, by having its voice drowned out by the other members, the National Executive assured its members that the C.A.A would remain independent and strong. ${ }^{3}$ In joining the A.C.B., the C.A.A. again positioned itself as heteronomous producers of art within the literary field, interested in securing financial success over praising "art for art's sake." One major advantage of the creation of the A.C.B. for the C.A.A., however, was that the new association could manage Book Week, which would allow the C.A.A. to focus its attention elsewhere (and might distance the association from any complaints as well). The inaugural meeting of the A.C.B. was held on February 22, 1936 in Toronto, where Lord Tweedsmuir gave his first address as Honorary President of the C.A.A.

The A.C.B. quickly gained impressive support. In the Mail and Empire, J.V. MacArke stated that within the first year of its existence, the A.C.B. "had created a greater stir in the book world than any similar event or organization in our [country's] history" (6). The first major event that was run by the A.C.B. was the First National Book Fair, held at the King Edward Hotel in Toronto during Book Week, November 9-14, 1936. The Book Fair, with the explicit aim of "increas[ing] the habit of reading throughout the country," saw almost 15,000 visitors during its week long run, and was considered to be a huge success ("Book Fair" 6). As a result, Book Fairs were hosted in cities across Canada. Unfortunately, the success of the A.C.B. did not last. The C.A.A. eventually withdrew its support from the association over fears that publishers within the

\footnotetext{
${ }^{3}$ It is worth noting that similar fears surfaced a decade later when the C.A.A. joined the Canada Arts Council, as discussed in chapter three.
} 
A.C.B. wanted to use the C.A.A.'s membership and finances for its own commercial ends. In a letter to Leslie Barnard, William Arthur Deacon suggested that in believing publishers would treat the C.A.A. fairly they "ha[d] been played for suckers and ha[d] been suckers" (qtd. in Thomas and Lennox 194). As a result of the C.A.A. withdrawing, the A.C.B. disbanded in May 1939. Pelham Edgar, who had been president of the C.A.A. when the A.C.B. was created, and one of its major supporters, listed the failure of the A.C.B. as the "major disappointment of [his] career." He added: "It seemed to me possible to achieve a fusion, with commercialism duly subordinated, of all the interests that lie behind the book. I suppose I was a fatuous idealist, for I discovered that the commercial aspect still dominates the field" ("Past President's Forum" 14). By leaving the A.C.B., the C.A.A. suggested that it was not willing to see the literary field become entirely heteronomous, and dominated by agents who were solely interested in commercialism. Implicit in Deacon and Pelham's comments is the desire for Canadian literature to have some autonomy. The C.A.A.'s involvement in the A.C.B. suggests that the C.A.A. was attempting to walk a fine line in the literary marketplace. The C.A.A. was willing to relinquish some of the literary field's autonomy to cooperate with other agents in the literary field for economic gain, as long as it was in control. When it became clear to the C.A.A. that it was going to lose control to the publishers, and risked having the literary field become almost completely heteronomous, it abandoned the A.C.B.

The second major initiative that the C.A.A. began in 1935-36 was the creation of the Canadian Poetry Magazine. Since 1925, the Montreal Branch of the C.A.A. had been running a yearly poetry contest, and publishing Poetry Year Books, which had been hugely successful. Therefore, in 1934, the Montreal Branch appointed a special 
committee to determine the feasibility of the branch publishing a Canadian poetry magazine. The committee determined that it was feasible, with five issues a year, while paying its contributors, and with a subscription of $\$ 2.00$ per year ("Proposed Poetry Magazine" 14). The National Executive agreed to sponsor the project, as long as it was financially feasible and was run by the Montreal Branch. Postcards were sent to 1,200 competitors in previous Montreal Poetry Contests, to see what level of support would be received for the magazine. Only "302 provisional promises to subscribe [were received], and the Montreal Poetry Group decided that it could not take the financial risk involved" ("Poetry Magazine Wanted" 6). Dr. E. A. Hardy, however, urged the National Executive to take on the project themselves, noting that it would be "a practical service which would increase the membership and make those who were already members feel that the Association was really doing something constructive," and that it "would create a market, though perhaps limited, for good poetry" ("Poetry Magazine Wanted" 6-7). The National Executive agreed with Hardy, and provided $\$ 1,000$ as security for the first year's run of quarterly issues. E. J. Pratt was appointed as the first editor of the magazine, with Andre Macphail, Mrs. John Garvin (Katherine Hale), Charles G. D. Roberts, and Duncan Campbell Scott making up the rest of the editorial board. The first issue appeared in January 1936. The magazine went through a number of editors, and almost met bankruptcy a few times, but it managed to survive until 1968, when it was absorbed into the Canadian Author and Bookman.

In its commitment to publishing a magazine devoted entirely to poetry, despite the financial risk, and the low readership, the C.A.A. appears to support the creation of 
autonomous art, contradictory to most of its other endeavors. ${ }^{4}$ In part, publishing the Canadian Poetry Magazine demonstrates that the C.A.A. was not always consistent in its views on literature. An association as large as the C.A.A. would have difficulty remaining entirely heteronomous or autonomous. As a result, at various points, it would inevitably pursue initiatives that were either more autonomous or more heteronomous. While the Canadian Poetry Magazine can be seen as an initiative more closely aligned with the autonomous pole, part of the C.A.A.'s desire to publish the Canadian Poetry Magazine, as Hardy suggests, was to create a larger market for poetry. In other words, the Poetry Magazine could be seen as an attempt by the C.A.A. to make the publication of poetry less autonomous, by providing a further profit-based venue in which poetry would be published. It is also worth noting that the magazine was often criticized, especially in its early years, for publishing “bad" poetry, i.e. not aligned with its critics' (often modernists) aesthetic values. This debate over the content of the Poetry Magazine is discussed later in this chapter.

\section{The Creation of the Governor General's Literary Awards}

The third major initiative of the C.A.A. that began in 1935-1936 was the Governor General's Literary Awards. Although they were not created until a decade later, the first mention by the C.A.A. of attempting to establish a national literary award appeared in

\footnotetext{
${ }^{4}$ Bourdieu identifies poetry, in $19^{\text {th }}$-century Paris, as the most autonomous genre; the same was true at midcentury Canada. Carole Gerson notes, for example, that well into the twentieth century, it was common for the publishing of poetry to be financed by the author, and not the publisher. As she notes: "few publishers ever risked their own money on literary genres (especially poetry) and few authors expected them to do so" (Canadian Women 71).
} 
1926. At the sixth annual C.A.A. convention, Leslie G. Barnard put forward a resolution, which passed, that the:

[C.A.A. National] Executive be requested to consider and take any action that may seem to them desirable in the matter of asking federal aid for the encouragement of Canadian literature, somewhat along the lines of the present yearly awards made by the Provincial Government of Quebec.

That preferably no other condition of entrance be imposed than the works considered be published during the year, in Canada, by resident Canadians; and that awards be made for the best material so published, under some sort of classification as Poetry, Novels, Short Stories, Literary Criticism, Essays, etc., etc. ("Resolutions Committee" 15)

Bernard is referencing the Quebec Literary Competition, which was established in 1923, and was instituted by the Quebec Government. As a result of Barnard's resolution, the National Executive asked the committee in charge of Canada's Diamond Jubilee of Confederation that "in the name of Confederation they endow in perpetuity an annual prize of perhaps one thousand dollars to be awarded for the most notable work published each year by a resident Canadian"5 (Kirkconnell, "Secretary's Report" 6). The Diamond Jubilee Committee gave the proposal "a courteous hearing" and "reserved it for further consideration" (6). The Jubilee Committee did award a prize for a literary competition held in each province, and asked the C.A.A. to "conduct a Dominion-wide poetry and

\footnotetext{
${ }^{5}$ In suggesting that the award be for a work published by a "resident Canadian," and not a book published by a Canadian publisher, the C.A.A. is acknowledging the difficulty authors had publishing in Canada. The award, however, was clearly meant to reward Canadian authors who remained in Canada, and did not move abroad for greater financial success, as was common at the turn of the twentieth century. This question of eligibility around citizenship is raised again later during the judging of the GG awards, where the C.A.A. modified its rationale, and decided that nationality was more important than residency.
} 
prose competition for adults" (Allison 4). ${ }^{6}$ The C.A.A. was "honoured" by this request, but it had been hoping for more:

We are hoping that when "the shouting and the tumult," likewise the ringing of July the First die away, [the Jubilee Committee] will take into their serious consideration a suggestion forwarded to them by our national executive two months ago, that, out of the quarter of a million dollars voted for the Jubilee celebration by Parliament, there should be set aside a sum sufficient to provide an annual award to be known as the Confederation Prize for the best native work of the year in either verse or prose. . . Very little has been done in Canada to encourage the men and women who by their writings do more than any other class to set up national ideals of beauty and truth. Our federal government has established a national gallery and has done considerable to encourage Canadian art. We approve most heartily, but we feel that the sixtieth anniversary of confederation is not too early for the government to recognize the importance of our national song and story. (Allison 4-5)

This annual Confederation Prize never came to fruition. Four years later, at the 1930 Annual Convention, Lloyd Robertson proposed a resolution, "to reaffirm the [1926] resolution . . . in favor of an annual literary prize, to be awarded by the Dominion Government” (“Government Prize” 8). This resolution was never successfully implemented, and the question of literary awards was not raised for another five years. In the spring of 1935, Albert H. Robson, President of the Toronto Branch, sent a letter to William Arthur Deacon asking him for advice on how the C.A.A. should spend

\footnotetext{
${ }^{6}$ Judges in this competition were: Sir Andrew Macphail, Newton Mactavish, Napier Moore, Judge Fabre Surveyer, Aimé Plamondon, and Jules Tremblay.
} 
money to improve the conditions of authorship in Canada. In his response, Deacon suggests that "There are four things to do; and I speak as one who has mothered Canadian literature for 15 years and learned a great deal of publishing and the troubles of authors and of readers' taste and influencing it." ${ }^{, 7}$ These four things were ranked by feasibility based on the amount of money available:

1. We need a system of empty honors, carrying official approval which costs nothing and leaves the money to be used where really needed.

2. Cash prizes and awards on a compensatory basis. ${ }^{8}$

3. A system of pensions, including something like scholarships to help people to write their best and most needed books. . . .

4. Practically, we need a well capitalized commercial publishing house for Canadian books only. Sound business management, good literary advice, shrewd advertising, and the thing will be self-sustaining. Believe me, the manuscripts are available. Under present conditions in the trade, it is far too difficult to get published. (Letter to Albert Robson)

His letter ends by suggesting the need for a committee "of not less than three nor more than five members," with equal representation from both government and authors, who

\footnotetext{
${ }^{7}$ Deacon's suggestion that he has "mothered" Canadian literature is note-worthy for several reasons. First, it speaks to how Deacon views his relationship to Canadian literature- - he considers himself to be, at least partially, responsible for its growth and development. This outlook can be seen in a number of Deacon's writings. Secondly, it indicates Deacon's paternalistic views - he knows what is best. As his biographers note, "Deacon had a well-developed set of beliefs and prejudices about literature and life. He set out, not only to nurture and encourage Canadian writers, but in a sense to instruct them in what and how a Canadian writer should write and in what a Canadian should and could be" (Thomas and Lennox 37). And, finally, it is gendered feminine, suggesting that Deacon views himself as nurturing literature (such as guiding readers through his reviews) as opposed to forcing his views on others-Deacon is not always successful in restricting himself to an advisory position, as this chapter shows.

${ }^{8}$ Although Deacon does not explain what he means by "compensatory," it is likely that he is suggesting helping authors in financial need. He might have been thinking of the Canadian Authors' Foundation, founded by the C.A.A. in 1931, and which later became the Canadian Writers' Foundation.
} 
would be paid for their labour. In this early anticipation of state-funded arts projects,

Deacon envisioned that this committee "would handle the whole fund, however gathered, and have a very free hand in fixing amounts of prize monies, according to need of the writer, according to public service rendered, and as to merit solely as art." Interestingly, Deacon prioritizes cultural capital over economic capital; the C.A.A. should establish "empty honours," i.e. no monetary prize. Most likely this rationale is based on the fact that Deacon knew the C.A.A. had no funds to spend on a new initiative, and that cultural capital would still help individual authors without costing the association anything.

Deacon would have been well aware that his final two suggestions were very unlikely to come to fruition. Deacon later claimed that his first suggestion was the catalyst for creating the Governor General's Award for Literature.

On September 20, 1935, Robson sent a letter to Pelham Edgar, President of the C.A.A., reminding him that they had discussed "asking our new Governor General to do something for Canadian Literature along the lines that Bessborough did for Drama" (Letter to Pelham Edgar, 20 Sept.). ${ }^{10}$ What the C.A.A. hoped Lord Tweedsmuir would do for Canadian literature is clarified in another letter from Robson to Edgar on November 18, 1935. He writes:

\footnotetext{
${ }^{9}$ In this letter, Deacon does not appear to have much faith in Canadian authors to control their own earnings. In his view of an author-government committee, Deacon suggests that one of their largest jobs should be controlling how authors spend their private funds:

Having seen something of the folly of successful writers with their money, I am seriously convinced that if the government helps us, we should be willing to concede, even petition for, a public financial committee to take over and administer the affairs of authors ... Beside them, a drunken sailor is a model of thrift. . . If I get the money I want for pensions and awards, etc., I am certainly going to demand power to regulate the private spendings of any author who has ever taken cash from the fund. The lucky Canadian authors have already thrown away enough money to finance the whole scheme of this letter-publishing house incl[uded]. I am serious about this. This is another example of Deacon's paternalistic attitude towards other Canadian authors.

${ }^{10}$ Vere Ponsonby, ${ }^{\text {th }}$ Earl of Bessborough, was the Governor General of Canada immediately preceding Tweedsmuir, from 1931-1935. During his tenure as Governor General, he was foundational in creating the Dominion Drama Festival, which promoted amateur theater in Canada.
} 
After talking over with members of the Executive Committee we have come to the conclusion that the finest stimulant possible to give to Canadian literature, would be a series of official Governor General awards to the various classes of Canadian literature.

... In literature a shield, medal or gift could be officially presented for the finest book published the previous year in several classes, such as Poetry, History, Biography, Novel Essays and Short Stories....

The prizes need not be of any great value, but should be dignified. The winning of the Tweedsmuir Trophy would carry with it such nation-wide publicity as to give the work national prominence. (Letter to Pelham Edgar, 18 Nov.)

Robson echoes Deacon's prioritization of cultural capital over economic capital, noting that the awards should be able to draw nation-wide publicity. A week later, Edgar met with Lord Tweedsmuir who "expressed his approval of the institution of a special AWARD OF MERIT for literary work in the Dominion.” This message was sent to all members of the C.A.A, asking them to offer suggestions as to "the most desirable character and conditions for such an award" (Howard Kennedy, Letter to C.A.A.). When Lord Tweedsmuir seemed agreeable to the endeavors of the C.A.A., the association took the opportunity to have the Governor General consecrate its activities as widely as possible. Not only was Lord Tweedsmuir made honorary president of the C.A.A., he also supported the C.A.A.'s three major projects of 1935-1936 - the Association of Canadian Bookmen, the Canadian Poetry Magazine, and the Governor General's Literary Awards. This wide support of the C.A.A's many activities seems to 
have caused much confusion during the first year of the Governor General's Awards. The Governor General had agreed to "institute a Tweedsmuir Poetry Award, for either the best Canadian poem in French or English, or the best book of verse published in any one year" (Tweedsmuir, Letter to Pelham Edgar, emphasis added). In the editorial to the fourth issue of the Canadian Poetry Magazine, the C.A.A. announced that this award would be for "the outstanding poem appearing in this magazine." Edgar, however, had hoped that the Governor General would also consent to give an award for the best piece of fiction and non-fiction in the previous year. The Governor General, however, did not agree, as Shuldham Redfern, the Governor General's secretary, explained to Edgar: "He does not, in fact, wish to make more than one award, and I think this is clear from the correspondence" (Letter to Pelham Edgar). When the C.A.A. decided that it would provide, at the association's expense, the awards for Fiction and Non-Fiction, Lord Tweedsmuir stated that the C.A.A.'s medals had to look different, and be made from inferior metal, than the Poetry award he was donating; Tweedsmuir was insistent that the award he was providing look different and superior to the awards provided by the C.A.A. The C.A.A. agreed, and in exchange, the Governor General agreed to physically present all the awards (Poetry, Fiction, and Non-Fiction) to the winning authors, but would personally only donate the medal for the poetry award. Frederick Pereira, Assistant Secretary to the Governor General, explained to Edgar:

His Excellency did not undertake to donate prizes for fiction and non-fiction. However, the Governor General will be pleased to make the presentation of these if they are provided by the Canadian Authors' Association. He has no objection to these prizes being styled "The Governor General's Annual Literary Awards" if 
your Association so desires, but the only prize he is prepared to donate is a medal for the best poem. (Letter to Pelham Edgar)

Lord Tweedsmuir wanted the medal for poetry to stand apart from, and above, the medals for fiction and non-fiction.

To further complicate matters, earlier in 1937, Margaret M. Howard, a former president of the Toronto Branch, had donated money for a prize in honour of the work of the late Susie Frances Harrison. This prize, to be known as the "Seranus Memorial Prize" was also, by complete coincidence, to be given for the best poem appearing in Canadian Poetry Magazine during the previous year. ${ }^{11}$ In other words, the best poem would receive both the Seranus Memorial Prize and Lord Tweedsmuir's poetry prize. On November 24, 1937, Lord Tweedsmuir addressed a large crowd at the C.A.A.'s "Canadian Poetry Night," held in Toronto, to provide support for the Canadian Poetry Magazine. He then presented the first Governor General's Annual Literary Awards for fiction and nonfiction, although the medals themselves had been created and paid for by the C.A.A. Lady Tweedsmuir then presented the Seranus Memorial Prize of \$25 and Lord Tweedsmuir's Prize (the silver medal paid for and donated by Lord Tweedsmuir) to George Herbert Clarke for his poem "Hymn to the Spirit Eternal.” In the end, the medal that Lord Tweedsmuir actually donated has been written out of Canada's literary history, while his name has become ingrained in the history of the two awards that he considered separate, and which he refused to donate. ${ }^{12}$

\footnotetext{
${ }^{11}$ Unfortunately Margaret M. Howard died on November 9th, only two weeks before the award was to be presented.

12 The official website for the Governor General of Canada incorrectly notes on the page for Lord Tweedsmuir that "In 1936, encouraged by Lady Tweedsmuir, he created the Governor General's Literary Awards, which continue to be Canada's most prestigious recognition of literary merit" ("Lord Tweedsmuir").
} 
Although Lord Tweedsmuir refused to pay for the medals that were presented for fiction and non-fiction, by physically presenting the awards, Lord Tweedsmuir's statusas a literary celebrity and as the bearer of British political authority—consecrated the winning authors. It is these medals—-the Governor General's Literary Awards—with their consecratory power, that the C.A.A. continued to award, year after year. Equally important, however, are the two awards that did not continue to be awarded after the first few years, which have been all but forgotten: Lord Tweedsmuir's Poetry Prize and the Seranus Memorial Prize. Taken together, these three literary awards reveal the various forms of power at play in the bestowing of these prizes. In juxtaposition to the awards that were physically presented by Lord Tweedsmuir, and which he viewed as inferior, is the award that Lord Tweedsmuir actually paid for, and donated. This award was presented by his wife, Lady Tweedsmuir, along with the Seranus Memorial Prize.

The Seranus Prize was funded by Margaret M. Howard to honour the poet Susan Frances Harrison. At her death in 1935, Harrison was considered to be one of Canada's great Confederation Poets, and one of the few women to be classified in this group, alongside poets such as Pauline Johnson and Isabella Valancy Crawford. Harrison was also the Honorary President of the Toronto Branch of the C.A.A. In creating the prize in Harrison's honour, Howard was hoping to "perpetuat[e] the memory of the woman ... who was the first to appreciate the charm and historic value of the French chansons sung in the Province of Quebec. She gathered them together and so prepared the way for men who very many years later took up this phase of Canadian literature and, with it, made quite a name for themselves in literary circles" (Brode 15). The Seranus prize was bestowed by a woman author to honour another woman author for her pioneering work in 
Canadian literature, years before the subject was taken seriously by men. The

Tweedsmuir Poetry Prize, however, overshadowed the importance of this award, as they were presented together.

The gendered aspect of the awards, and of their disappearance from literary history, can be seen in the way that the two prizes were reported. An article entitled "Woman's Point of View," by Bride Brode concludes by nothing that "The winner of Mrs. Howard's award is due for two honours, for some time after she instituted the 'Seranus' Memorial, his Excellency, Lord Tweedsmuir, also offered a prize, a medal, to be given through the Poetry Magazine for the best poem of the year" (15). For Brode, Lord Tweedsmuir's Poetry Prize is secondary — chronologically (in terms of its creation) and in its prestige. By contrast, an article entitled "Tweedsmuir Awards," appearing a few weeks later, and most likely written by Deacon as the literary editor, flips the importance of the two awards, noting that Tweedsmuir's Prize "is supplemented by the $\$ 25$ cash Seranus Prize." This article concludes by offering "gratitude to the Governor-General for being the first to give official recognition to literature in Canada" ("Tweedsmuir Awards" 23). This concluding remark is telling of both Deacon's, and the C.A.A.'s, misogynistic views; despite Howard's award, the Governor General's awards become the "first." Importantly, both of these awards have disappeared from literary histories. Arguably, this disappearance is the result of a number of factors. First, these awards did not have long lives. A Tweedsmuir Medal for the best poem appearing in the Canadian Poetry Magazine during 1937 was awarded posthumously in 1938 to Mrs. Dalton, for her poem entitled "Wheat and Barley." This was the last time the Tweedsmuir Medal was awarded. Similarly, I cannot find any reference of the Seranus Prize being awarded after 
the inaugural award in 1937. This is most likely due to the death of Margaret M. Howard in 1937, as she was the patron of the award. In not continuing to award these two prizes, however, the C.A.A. demonstrates that it did not believe that these awards carried the same consecratory power as the Governor-General Literary Awards. In continuing to award the GG Awards, and not the Tweedsmuir award, the C.A.A. indicates that it finds greater symbolic capital in the connection to the British monarch than it does in the literary celebrity of Tweedsmuir himself. Although the Tweedsmuir Medal was actually gifted by the Governor General, it was presented to the winning poet by his wife.

Because Lady Tweedsmuir presented the poetry award, as well as the Seranus prize, both awards become gendered, with poetry being labeled as feminine, while fiction and nonfiction become labeled as masculine. As a result, the decision by the C.A.A. to no longer award either the Tweedsmuir Poetry Prize or the Seranus Memorial Prize is another example of the male-run executive disavowing, and distancing itself from, the feminine.

After 1937, Lord Tweedsmuir had no input into the Governor General's Literary Awards, although he remained the honorary president of the C.A.A. until his death in 1940. The C.A.A. continued to administer the GG awards, and a poetry category was added for the 1937 awards. As Deacon notes, "Lord Tweedsmuir authorized the use of the name of his office in perpetuity for [the Governor General's Literary Award's] purpose. He contributed nothing but the name" (Letter to Kathleen Hobday). While Deacon is dismissive here, partly because he wants to note the fundamental role that the C.A.A. played in the award's creation, he overlooks the importance of the social and cultural capital that the name of the office of the Governor General provides. In 
"contributing nothing but the name," Lord Tweedsmuir consecrated the awards, an act that cannot be easily dismissed.

\section{Judging the Awards}

Examining how the association judged the Governor General's Literary Awards in the twenty-three years that it ran them is crucial to understanding how the association attempted to use the awards to support its ideals. Early in the award's conception, in February 1936, the C.A.A. suggested "judges to be named by sections One and Two of the [Royal Society of Canada], and by C.A.A., which might appoint two English and two French judges; preliminary judging to be done by two members (rotating) of a panel of twelve or fifteen" ("History of the Governor"). ${ }^{13}$ By March, the plans had been modified to have three judges per category, "One English and one French in each department by the Canadian Authors' Association; one English and one French by the Royal Society of Canada; one English and one French by the Association of Canadian Bookmen"

("History of the Governor"). The C.A.A., however, quickly regretted the decision to involve the Royal Society of Canada. As Deacon notes, the Royal Society "thought two years a reasonable time to let judges reach a decision, and the books were forgotten when awards announced. Then they chose the damndedest [sic] things that nobody by [sic] a dessicated [sic] professor would ever like to read" (Letter to J. Markowitz). As a result,

\footnotetext{
13 Originally, the awards were going to be presented for both French and English books. It is not clear when the decision was made to only award books published in English, but it must have been decided sometime in 1936. In 1944, the National Executive offered the President and the Executive of la société des écrivains canadiens "the right to share the Governor-General's Awards in the French language, exercising its own control but announcing jointly; but this offer was declined" (McDowell). The first award for a book published in French was awarded in 1959, after the Canada Council had taken control of awarding the prize.
} 
the arrangement between the C.A.A. and the Royal Society of Canada only lasted two years, and in 1938, the national executive of the C.A.A. decided that the association should be solely responsible for the judging of the awards. The National Executive would appoint three judges, to act as a chairman in each award category, and these three judges were "empowered to add three more to their number," with the caveat that "The judges shall be geographically distributed, as fairly as possible, bearing in mind the necessity of having thoroughly competent and open-minded persons" ("History of the Governor"). This arrangement of the National Executive appointing one chairman judge to each category, who then appointed their own co-judges, was used until 1941, although the number of co-judges per category dropped from three to two in 1939. Deacon notes that "This system was better than [the] Royal Society but not good enough. There were enough incompetent judges to ensure some of the selections being bad" (Letter to J. Markowitz). In 1941, the National Executive discussed the method of choosing judges, and considered two different options. The first was to keep the same method that they had used for the last few years. The second option was to enforce "geographical distribution of the committees (i.e. Western Canada, Central Region, Maritimes), with the three judges in each division to be located as nearly as possible in the same centre, to facilitate consultation. It was recognized that while the last mentioned might seem democratic in purpose, it would involve difficulties of shipment and consultation" ("History of the Governor"). This option would, for example, have all the poetry judges located in the Maritimes, while the Fiction judges would be located in the Central Region of Canada, and so on. The National Executive decided to abandon both of these suggestions, and to appoint all the judges in each category, while still trying to achieve geographic 
distribution. In 1942 it was decided that starting in 1943 the names of the judges would be announced publicly after the winners had been announced. (See Appendix I for a full list of the judges.)

During the first decade of judging, judges were expected to discuss amongst themselves, and come to an agreement over which book should win. This method of judging, however, came with a number of problems. When Deacon was acting as judge in 1938, he wrote to Roderick S. Kennedy, Acting National Secretary, asking how the judging operated: "Do I render decision to you or consult with other Judges? Do I vote for one only or grade three in order of merit?" (Deacon qtd. in Roderick Kennedy, Letter to Pelham Edgar). Kennedy wrote to Pelham Edgar, C.A.A. President, for clarification. He notes:

For three or four Judges in different cities to consult would seem difficult. For two in one city to get together and make a decision would put the third in another city into a position he would not appreciate.

Last year, as far as I can remember, the Judges gave their choice, and one or two alternatives with the reasons, and with the strength of their opinion ... then communicated with the other Judges, until a decision was reached. (Letter to Pelham Edgar)

Requiring judges to come to a unanimous decision amongst themselves not only proved tedious and time-consuming, as Kennedy suggests, but it also allowed for disagreements among the judges. The problems with judging in the first decade of the awards are clearly seen in an example from 1939. Deacon was the chairman of the committee of judges entrusted to choose the best book of non-fiction published in 1938. His two co-judges 
were E. J. Pratt and V. B. Rhodenizer. On March 9, Deacon wrote to Eric Gaskell, national secretary of the C.A.A., with the results of the committee's voting. The two books competing for the top spot were John Murray Gibbon's Canadian Mosaic and George Wrong's The Canadians: The Story of a People. Deacon writes: “on straight vote, Wrong wins over Gibbon - two firsts and a second against one first and two seconds" (Letter to Eric Gaskell, 9 Mar. 1939). Deacon and Pratt had voted for Wrong to win, while Rhodenizer had voted for Gibbon. Despite losing in the votes, Gibbon won the Governor General's Award for non-fiction in 1938.

Wrong did not win the award because, as Deacon explains to Gaskell, “Arithmatic $[$ sic $] \ldots$ is only part of the story" (Letter to Eric Gaskell, 9 Mar. 1939). Deacon had written to Gaskell asking for advice on how to choose a winner: "Rhodenizer is so strong for Gibbon that it balances the slight edge that Pratt and I accord Wrong." Deacon had other reservations as well. He notes that he is "strictly against posthumous awards," noting that Wrong is 80 and, "Should he die, I would switch instantly to Gibbon." He continues:

These votes being equal, actually, it comes down with me to the question of whether we should remember all Gibbon has done for [the Canadian Authors Association] and use this means to thank him, or whether we should use the medal as a suggestion to Wrong that he might leave the C.A.A. something in his will. (Letter to Eric Gaskell, 9 Mar. 1939)

Deacon's reservations demonstrate that "literary merit" is only a small concern for him as a judge, which he openly admits: "These are the thoughts of an officer, not of a judge." He is not, however, apologetic about this approach: "these are our medals, it comes down 
to a straight question of personalities and which winner would be most acceptable to the Association” (Letter to Eric Gaskell, 9 Mar. 1939). Before Gaskell could reply to Deacon's letter, Deacon sent a letter to Leslie Gordon Barnard, the President of the C.A.A., repeating his concerns, and adding that "Gibbon will be hurt if he loses" and that Wrong "is comparatively wealthy" (Letter to Leslie Gordon Barnard). For Deacon, then, acceptable criteria for a winning book included: the age of the author, the financial situation of the author, whether the author could or would help the association, and, whether losing would hurt the author's feelings. ${ }^{14}$

Gaskell responded to Deacon in two separate letters, one official and one personal. In the official letter, Gaskell is careful to remain impartial: "It would be highly improper for me, as a member of the National Executive, to voice an official opinion" (Letter to William Deacon, Official). Gaskell notes that "on straight vote, the award goes to The Canadians," and reminds Deacon that he must be the final adjudicator, and that “THIS IS A LITERARY AWARD.” Gaskell, however, is receptive to Deacon's problem of the two books being closely tied on the level of "merit" and suggests that Deacon decide "which of [the two books] makes the more pertinent contribution to our knowledge of Canadian problems?" His official letter does not address any of the reservations raised by Deacon. In his personal letter, Gaskell repeats his opinion from his official letter, telling Deacon that "As a judge, your ultimate decision MUST be based on the considerations I have already outlined in my [official] letter" (Letter to William

\footnotetext{
${ }^{14}$ The disappointment of authors who did not win the awards appears to have been a continuing problem for the association. In 1952, Deacon wrote to B.K. Sandwell: "You may not have realized the pangs felt by authors who do not win. Ken Wells of the Owl Pen and Hugh Garner are two of the poor sports who resigned their memberships in the Ass'n as soon as they learned their books had not won medals" (Letter to B.K. Sandwell). Authors did not need to be members of the C.A.A. to win the GG award, although the executive of the C.A.A. often subsequently tried to convince winning authors to join the association if they were not already members.
} 
Deacon, Personal). In this personal letter, however, he does acknowledge Deacon's reservations. He notes, "The age factor is unimportant. If you feel that Professor Wrong's book is the best, in the spirit of the competition, by all means award the medal to him. $\mathrm{He}$ is an author, and 'literary merit' is not confined to younger writers." Further, he notes that "[Gibbon] has pulled the C.A.A.'s chestnuts out of the fire on more than one occasion." This, however, must be a "secondary consideration —in fact, it is not even in the stars, in a literary competition" (Letter to William Deacon, Personal).

Deacon, in turn, sent two letters in reply to Gaskell. Deacon's official letter informs Gaskell that the judges "unanimously agree that the 1938 Award of the Governor-General's medal for General literature is to be bestowed upon Mr. John Murray Gibbon of Montreal for his volume entitled 'Canadian Mosaic"' (Letter to Eric Gaskell, Official). This "unanimous" decision is the result recorded for history. In his personal letter to Gaskell, however, Deacon thanks him for his advice, noting that it helped him, before explaining why he disregarded it:

Now, my Boy, listen to Daddy. In your youthful idealism you believe there is a way to pick one [book] as superior to another. I do not think so. I believe these two, though different, are as equal as two unlike things can be. Edgar, Pratt, Rhodenizer, being professors, judge by faults - the "mistakes" of school days. Hence I ignore most of what they say. ...

I found these two [books] equal on points.... Hence, despite all you say, if there is some other consideration to throw in the balance, that may turn the scale. I found that in what I conceive to be Wrong's indifference to the honor. Though well off, he refused to pay for copies of his book for the judges. I take it 
[from this that] he is indifferent to the medal. ... and it certainly cannot do him as much good as it will do [Gibbon]. (Letter to Eric Gaskell, Personal)

Therefore, in the end, Deacon explains that Wrong did not win the GG award because he had been too cheap to pay for copies of his books to be sent to the judges: "I ruled out a contender who didn't want the honor." ${ }^{15}$ Deacon remains unapologetic about his rationale. Although he claims to agree with Gaskell "in the main" about "pure decisions," in the end, he is thankful for the subjective nature of the awards: "thank God, we control this matter and our business is chiefly to see that the medals go to fit people and are handed out where they will do most good to recipients and to our craft as a whole. We are often going to find that ... we shall give a medal to $\mathrm{M}$ because $\mathrm{N}$ got it last year, or something like that" (Letter to Eric Gaskell, Personal). Deacon's view on the "proper" method for judging the Governor General's Literary Award cannot be easily dismissed as the opinion of a single judge during one year of the awards. Deacon's views are an essential component of the history of the awards as a whole, as I discuss later in this chapter. Curiously, Deacon himself later complained about the way judging was orchestrated during the 1930s, noting that it allowed for "one strong person on the committee [to] brow-beat the others to vote for his choice" (Letter to [Unknown]).

Despite this awareness, Deacon continued to "brow-beat" his fellow judges. In 1940, he was the chairman of the fiction category, along with co-judges E.J. Pratt and Charles Clay. The final decision was between Irene Baird's Waste Heritage and Franklin McDowell's The Champlain Road. Pratt placed McDowell's book at the top of his list,

\footnotetext{
${ }^{15}$ What Deacon fails to note throughout the entire exchange is that he was the one who had suggested to Wrong that he should write The Canadians, and that Wrong had thanked Deacon for providing him with "the inspiration" (Thomas and Lennox 172). For more on this exchange, see Thomas and Lennox, William Arthur Deacon 171-2. This provides an interesting contrast to the 1940 debate between McDowell and Baird, discussed later in this chapter.
} 
"though the margin over Waste Heritage may be slight" (Pratt qtd. in Deacon, Letter to Charles Clay, 13 Mar. 1940), while Charles Clay favoured Baird's novel. As chairman, Deacon wrote to Clay offering his arguments for McDowell over Baird, in an attempt to come to an agreement between the judges. ${ }^{16}$ Deacon notes that Baird has ability_-"I think she has the most promising talent now in the field"- but considers her novel to be "slighter" than McDowell's. Deacon offered three reasons for voting for McDowell's novel over Baird's. First, he is "partly moved by the fact that Champlain Road has proved a popular book," noting that the book has had three printings in under two months. Although he notes that the awards should not "always underwrite the best-sellers," the award should go to the "book people prefer as a story." ${ }^{17}$ Second, Deacon felt that Baird would continue to write, and would produce "a more important and more popular" book in the future. And, Deacon argued, the awards had adopted a tentative policy "against repeats of medals to the previous winners," and Baird would be better served by a future award. Third, Deacon argued that he wanted to help Baird, but that the Governor General's Award would not do that, because it did not provide a monetary prize and "What that girl needs is money" (Letter to Charles Clay, 13 Mar. 1940). Deacon suggested that instead, Clay should provide a letter of recommendation on Baird's behalf to support her application for a Guggenheim Fellowship. Clay responded to Deacon and

\footnotetext{
${ }^{16}$ Deacon notes that he could just side with Pratt and out-vote Clay, but he writes to Clay to explain his position: "If it were just a question of voting, I could concur with Pratt and report; but we are still feeling our way in these awards and I want you satisfied. . . I'm not asking you to change an honest opinion. But I do wish to explain" (Letter to Charles Clay, 13 Mar. 1940).

17 In a letter to Hugh MacLeannan almost a decade later in 1948, Deacon discusses the popular success of some books, observing that it is "a matter of sheer chance." In this letter he picks Irene Baird as an example, noting that her novel "John was a best seller. Her Waste Heritage flopped as a war casualty. In the fall of 1939 nobody wanted to read about the late depression - any youth could have a job in uniform" (qtd. in Thomas and Lennox 246). The fact that Baird's novel was viewed as a "flop" surely impacted Deacon's decision to support McDowell.
} 
agreed to award McDowell the prize, "for the sake of presenting a united literary front to the general public" (Letter to William Deacon).

Carole Gerson points to this exchange between Deacon and Clay as an example of how the "invisible college of men," who were in positions of power in the Canadian literary field between the wars, effectively erased women writers from the canon. Gerson suggests that McDowell's win over Baird was not based on aesthetic judgment, but on personal connections. Gerson notes that Pratt favoured McDowell's work for its "massiveness and sweep and historical perspective" (Pratt qtd. in Gerson, "The Canon" 53), a trait shared by Pratt's own epic poems. More troubling, McDowell had written his novel at Deacon's suggestion, and in awarding the prize to McDowell, Deacon wanted to support his "friend McDowell, who is one of the finest men I know and a great asset to the literary movement" (Deacon qtd. in Gerson, "The Canon" 53). Finally, Gerson notes that Deacon was a past president of the Toronto branch of the C.A.A., and Pratt was the current president, and McDowell was a member of the Toronto branch, while Baird was "isolate[ed] on the West Coast" (52). Gerson highlights the personal connections that Deacon and Pratt had to McDowell to demonstrate "Baird's vulnerability to the whims of the literary power network" (52). Although personal connections probably had less of an impact of the Governor General's Awards after 1944 when judges were no longer allowed to consult each other, and a point system was established for determining the winner, the gendered power network described by Gerson was still an influence throughout the C.A.A.'s management of the Governor General's Awards. For example, from 1937-1959, one-hundred and eight people acted as judges for the GG awards, but 
only fifteen of them were women. ${ }^{18}$ It was not until 1942, during the seventh competition, that the first women judges were included. The list of judges also begins to reveal the identity of the men in the "invisible college of men" that Gerson describes. The C.A.A. oversaw twenty-four competitions of the Governor General's Literary Awards, and the following men all acted as a judge in more than twenty-five per cent of the competitions: Roy Daniells acted as judge 6 times, E.K. Brown and Roderick S. Kennedy both acted as a judge seven times, Ira Dilworth and A.W. Trueman both acted as a judge eight times, and finally, N.A.M. MacKenzie acted as a judge nine times. But no single person had a larger impact on the Governor General's Literary Awards than Deacon, who acted as a judge on ten separate occasions, not including the five years that he ran the Awards Board. Deacon, therefore, acted as a judge, or ran the awards, for a combined fifteen years, or just over sixty per cent of the competitions. Before the GG awards were established, Deacon viewed himself as having "mothered Canadian literature" for the previous fifteen years, a paternalistic role that is further fulfilled by his tenure with the GG awards.

One of the largest problems with the National Executive trying to oversee the running of the awards was made apparent in 1944. By March 1, 1944, the decisions for the Fiction, Poetry, and Academic Non-Fiction awards had been submitted, but a decision had still not been made about the Creative Non-Fiction award. Dr. V.B. Rhodenizer was the chairman of the Creative Non-Fiction award committee, along with co-judges Dr.

\footnotetext{
${ }^{18}$ These figures only include judges that were listed as "official" judges by the C.A.A. As a result, it does not, for example, include Juanita O'Connor who was one of the three original judges in 1943 for Creative Non-Fiction, as she was not listed as one of the official judges.

The 15 women judges were: Ethel Kirk Grayson, Mrs. Mossie May Kirkwood, Yvonne Stevenson, Margaret Clay, Eleanor Godfrey, Marguerite Roberts, Mrs. Percy Jacobson (May Jacobson), Mrs. Mary Weekes, Donalda Dickie, Constance Beresford-Howe, Mrs. W.G. (Margaret) Stobie, Grace Cooks, Mrs, M. St. A. Woodside (Eleanor Agnes Barton), Mrs. John (Sally) Creighton, and Reata M. Vansickle.
} 
H.L. Stewart and Juanita O'Connor. Charles Clay, National Secretary of the C.A.A., began sending telegraphs to Rhodenizer, encouraging him, and his co-judges, to come to a decision swiftly so that the C.A.A. could make the award announcement "in time to do the most good for the writers involved" (qtd. in "Minutes of the National"). On March 13, Rhodenizer informed Clay that the judges had determined that Merrill Denison's

Klondike Mike should receive the award. Upon receiving this news, Deacon informed the C.A.A. that Denison was ineligible because he had been born in the United States, and was therefore an American citizen. Clay contacted Rhodenizer with this information, asked the judges to pick a new book, and encouraged a hasty response. Rhodenizer responded that his vote was for John D. Robins's The Incomplete Anglers and O'Connor had voted for Wallace Reyburn's Glorious Chapter, but he had not received a response from Stewart. Therefore, Rhodenizer asked Clay to arrange an arbitration committee to decide between Robins's and Reyburn's book. This arbitration committee consisted of Deacon as chairman, along with co-judges Charles Sanderson and Charles Clay. ${ }^{19}$ Eight days later, Rhodenizer wrote to Clay informing him that the original judges had changed their minds again, and now wanted to give the award to Stephen Leacock's Happy Stories, "if it and author [are] eligible," otherwise the award should be given to Harry Symons's Friendship (qtd. in "Minutes of the National"). Clay informed Rhodenizer that the "machinery . . could not be stopped" and that the arbitration committee set up at Rhodenizer's request would have the final say on the award. Upon hearing this news, Rhodenizer's co-judges, Stewart and O'Connor, wrote to Clay, "stating their disapproval of the intervention of the arbitration committee," and Stewart asked for a "set of rules and

\footnotetext{
${ }^{19}$ The official list of judges for this category in 1944 only gives the names of the arbitration committee and not the original three judges.
} 
regulations controlling the method of handling the annual Governor-General's Awards" (qtd. in "Minutes of the National"). There was, however, no comprehensive set of rules and regulations, which, along with the strong-arming of judges in previous years, convinced the C.A.A. to overhaul the whole judging system.

Deacon submitted a resolution at the 1944 annual meeting of the C.A.A., noting that "a point has now been reached at which the importance and dignity of the Awards requires codification of all the existing motions and resolutions passed from time to time by the National Executive Committee." His solution was that "A board of five members, plus the National Secretary as member exofficio without vote, be forthwith appointed for a period of three years to assume full responsibility for the direction of the award system known as the Governor-General's Annual Literary Awards" (“Annual Meeting Resolutions" 12). In essence, the resolution would establish a committee that would run the awards at arm's-length from the National Executive. Importantly, this new committee would have final authority on all issues relating to the awards. The resolution passed, and the National Executive appointed Deacon to be the first chairman of the board, with Fred Landon, S. Morgan-Powell, V. B. Rhodenizer, and Charles Sanderson joining him as board members. This Awards Board ran the awards until the Canada Council took control in 1959.

Determining who would act as judges was only the first task the C.A.A. had to tackle. The second task was determining what criteria the judges would use to determine the "best" book. In 1938, the National Executive adopted "certain recommendations for the guidance of judges in future competitions," ("History of the Governor") although it is not clear what those recommendations were. At the same meeting, J. M. Gibbon 
suggested that the C.A.A. adopt a "point system of adjudication." After some discussion, Gibbon's suggestion was ignored, but "It was tentatively agreed that books entered in the General Literature class should be judged primarily on the basis of literary merit" ("History of the Governor"). In 1939, this was emphasized again, although the C.A.A. noted that "No definition of the term 'literary value' was given, this being left to the discretion of the judges" ("History of the Governor"). After the awards committee was established in 1944, however, Deacon made changes to try to remove some of the subjectivity in judging. First, the following criteria were established:

Books shall be judged for their literary qualities; but the Board shall bear in mind that the effect of decisions is that the Association is recommending these books to the public for general reading. Therefore, besides traditional standards of excellence, a high degree of public acceptance is desirable. Awards are not to be given for mere popularity, nor only for virtue too rare to be generally appreciated, but for a combination of high literary quality coupled with an appreciation of common taste among ordinary readers of intelligence and reasonable education. $(\text { McDowell })^{20}$

Deacon also adopted a point system, which he referred to as a complex mathematical formula, similar to the system that Gibbon had suggested years earlier. This new point system required judges to rank the books, in first, second, and third place. Also, judges were no longer required to converse amongst themselves to determine the winner. In fact, judges were not even told who else was acting as a judge. This solved earlier problems,

\footnotetext{
${ }^{20}$ This structuring of the criteria, with the emphasis being placed on a primary focus, such as "literary qualities," before being qualified by the C.A.A.'s real concerns, such as the fact that these books be acceptable to the "reading public," is a common rhetorical strategy of the association. This grammatical structuring is employed throughout the GG awards' history, and it allows the C.A.A. to walk the fine line that it was establishing.
} 
as "there is now no opportunity for one judge to talk another into agreement on the merits of any book being judged" (Deacon "Governor General's"” 26). (See Appendix II for the point system that was used.)

The point system, while intending to produce more "fair" results, was not without its problems. Arguably one of the biggest mistakes under the point system occurred in 1947. On April 8th, Ira Dilworth sent a telegram to Deacon, with his rankings for the Fiction category. He placed Selwyn Dewdney's Wind Without Rain in first place, followed by Edward F. Meade's Remember Me, and thirdly, Ralph Allen's Home Made Banners. He noted, however, that he had not quite finished reading Home Made Banners (Letter to William Deacon, 8 Apr. 1947). The other two judges in the category-Joseph Lister Rutledge and Charles Jennings—-had already submitted their choices, so Deacon calculated the scoring of each book. The result was that Mazo de la Roche's Return to Jalna had won, with 13 points. The next day, on April 9, Deacon sent de la Roche a letter notifying her of her win, and told her that "the award system is strengthened by the selection of a novel by Canada's most famous and successful writer of fiction" (Letter to Mazo de la Roche). Unfortunately, one day later, on April 10, Ira Dilworth sent Deacon his "final judgment." His rankings for first and third place remained the same, except he now placed Winifred Bambrick's Continental Review in second place. This change in Dilworth's ranking necessitated a recalculation of the points. This recalculation resulted in Bambrick's novel surpassing de la Roche's, with 18 points. As a result, the award for fiction for 1946 went to Bambrick and not de la Roche. De la Roche, understandably, took the loss fairly hard. As her biographer Ronald Hambleton explains, "During the forties one of the judges [of the Governor General's Literary Awards], in a lamentable 
lapse of taste, told Mazo de la Roche that she had won the award that year, but the final vote gave it to another author." Hambleton continues by noting that "She regretted the loss deeply," and suggests that it "certainly contributed to her decision to leave Canada and make her home abroad" (55). Although his desire to notify de la Roche so quickly of her win potentially resulted in her leaving Canada, this incident speaks to the trust that Deacon put into the point system. He respected the judges' rankings, even if it meant embarrassing himself to an author he highly respected. ${ }^{21}$ This appears to be in complete contrast to the subjective logic that he employed when awarding the prize to Gibbon instead of Wrong a few years earlier.

Another perpetual consideration that the C.A.A. had to face was the eligibility of the candidates. Originally, the criteria were fairly straightforward: "Only printed volumes are eligible — no manuscripts can be considered. It does not matter whether these are privately printed or published in the ordinary way," and "The books must be by Canadians, and have been first published or printed in the [previous] calendar year" (“Governor General's Award" 17). Problems quickly arose. In 1939, the National

${ }^{21}$ Unlike his distaste for other female writers of "popular" fiction, such as Montgomery, Deacon genuinely admired de la Roche's writing. He even compared other earlier popular novelists to her, noting that they did not have "anything like the skill of Mazo de la Roche" (qtd. in Rubio 433). Further, in 1949, Deacon wrote to the National Executive of the C.A.A., as chairman of the GG awards, noting that:

The Board is embarrassed by the unique case of Maze de la Roche, who has the greatest world reputation of any Canadian writer of all time. ...

Because Jalna and Whiteoaks were published before our medals were established, she could not compete when she would certainly have won. Later, her books invariably lost to newer writers whose novels were entirely fresh...

Miss de la Roche has been a loyal and helpful member of this Association; and the point has been reached at which the Board is uncomfortable about this distinguished novelist never appearing in the lists of authors honored by awards.

The Board would like to remove itself from this apparently invidious position by presentation of a unique award, within the framework of the Governor-General's Awards but distinct in every way and without the connotation that the honor would be repeated.

We therefore propose a gold medal, instead of the silver, but with the same design. Engraving would carry her name as usual; classification would be: FOR LITERATURE. ("GovernorGeneral's Awards Board Consults")

This appeal for a unique Governor General's Literary Award for de la Roche's contribution to Canadian literature was most likely fueled by the embarrassment of two years earlier. 
Executive had to decide if books published posthumously could be considered. Deacon suggested that they should not be considered, because the awards had been instituted "for the encouragement of Canadian writers, and that any material benefit which might accrue to authors of books selected for the Awards would be rendered negative if posthumous works were considered." Barnard argued against Deacon, noting that the "first object of the Awards was to recognize literary merit, and that this should be rigidly adhered to, irrespective of any other consideration" ("History of the Governor"). The C.A.A. continually raised concerns around this division between economic concerns and literary merit in the award's purpose. In the end, the executive decided to leave the decision to the discretion of the judges. In 1944, however, it was determined that "no Award shall be given for a posthumous work, nor to an author who has died prior to an announcement being given to the press" (McDowell). A second consideration regarding eligibility was raised in the same year concerning authors who had already won a prize. In this discussion, Deacon appears to argue against his earlier comment, when he notes that "the sole purpose of the competitions was to recognize literary merit ... and that all Canadian books ought to be judged on that basis" ("History of the Governor," ellipsis in original). No decision was made on the matter until 1941, when it was officially decided that having won the award previously would not disbar an author from winning again. Once Deacon became chairman of the Awards Board in 1945, however, he reversed his earlier opinion, and began urging judges to favour authors who had not previously won the award, as discussed later in this chapter.

The most constant question of eligibility, however, was the question of how the C.A.A. defined a "Canadian" author. During discussions in 1939, the case of Kenneth 
Leslie, who had won the award for poetry in 1938, was raised. The executive noted that "while a Canadian by birth, [Leslie] was a resident of Boston at the time of the announcement" ("History of the Governor"). The executive quickly agreed that the residence of the author was irrelevant, ${ }^{22}$ and decided that "in future competitions nationality, and not residence, should be regarded as the governing factor" ("History of the Governor"). This specific criterion was strictly enforced, with authors occasionally having to legally prove that they were Canadian citizens. In 1944, after Deacon was named chairman of the Awards Board, he wrote to Charles Sanderson and Fred Landon, both members of the Board, noting that the "First thing we shall have to deal with is a definition of what authors are eligible" because "Who is a Canadian will be important" (Letter to Charles Sanderson and Fred Landon). Deacon took this criterion very seriously, and defended it with equal strength. In a letter to Kirkconnell, Deacon presents his reasoning behind this conviction: "If we are guardians for the Canadian people, as I believe we are, we cannot give the medal to a foreigner" (Letter to Watson Kirkconnell, 18 Mar. 1944).

This subject was most fiercely contested in 1955, when Igor Gouzenko-a Russian who had defected to Canada in 1954—won the GG award for best fiction for his novel The Fall of a Titan. ${ }^{23}$ After his win, C. T. Bissell, one of the judges for the award,

\footnotetext{
${ }^{22}$ This is a reversal of the executive's logic a decade earlier when the C.A.A. proposed a literary award in connection with the Diamond Jubilee. As discussed earlier, in 1926, the C.A.A. suggested that any "resident Canadian" should be eligible. In the 1939 discussions, this earlier criteria is not mentioned, so it is difficult to know with certainty why the change in privileging nationality over residency. Part of the reason, I would argue, is that any criteria based on residency would exclude a number of prominent Canadian authors living outside of Canada, and also might allow an American to be eligible.

${ }^{23}$ Gouzenko's win of the GG was controversial for a number of reasons. Aside from two of the three judges (Deacon and Bissell) publicly stating that they had not voted for the book to win, there were also rumours that the novel had been ghostwritten. Furthermore, the artistic qualities of the novel were questioned. In 1955, Margaret Fairley wrote that the award was protested after the win "by those who care for the integrity and future of our literature" (2). She argues that the Gouzenko's award was "not the recognition of genuine
} 
spoke openly about voting against Gouzenko's novel (Deacon, "Fly Leaf," 9 Apr. 10).

Later that year, Bissell wrote the "Letters in Canada" for 1954 in the Toronto Quarterly Review where he extended his criticism of Gouzenko's novel, arguing that "Only narrow technical considerations can make this a Canadian novel" (261). Deacon took great offense to this remark, arguing that the C.A.A. was "acutely conscious of the difficulties of fixing literary nationality. But the problem was debated exhaustively" ("Fly Leaf," 9 July, 34). In his response, Deacon notes that

Subject matter is secondary. When Shakespeare wrote The Merchant of Venice, Two Gentlemen of Verona ... he was an Englishman despite his Italian settings. .

Canadian literature is what Canadians write, whether they be native-born, like me, or naturalized, like Gouzenko. ...

The terrible dither we were all in about literary nationality was settled by a Winnipeg judge of Icelandic blood ... who advocated Canadian citizenship and became advisor to the Dominion Government in designing the Citizenship Act of $1946 \ldots$. For the first time we knew what a Canadian was. It was a great relief to have it settled. ("Fly Leaf," 9 July, 34)

Deacon concludes by noting: "[The idea that] a Canadian book is a book written by a Canadian is a clean, simple definition that is capable of impartial application." Using citizenship as criteria for eligibility in the GG awards was appealing for its "impartiality." It allowed the C.A.A. to avoid the complicated process of determining what qualified as Canadian literature, the discussion that Bissell was interested in. In other words, applying un-Canadian product" and that "the [GG] award is a Cold War act, sponsored by the highest authority" (2). 
the criteria to the author, and not the novel's content, allowed the C.A.A. to avoid discussing the relative "Canadianness" of individual novels. As well, it should be noted that Deacon's strong advocacy for Gouzenko's claim to Canadian citizenship was most likely, at least in part, connected to the political ideology of Gouzenko's book. The novel's pro-liberal capitalist, and anti-communist, agenda would have been a version of Canada that Deacon would have supported. Therefore, Gouzenko can be Canadian, for the purpose of the awards, in part, because of his politics. It is unclear if Deacon's advocacy would have been as strong if his political ideology was less aligned with the novelist's. For Deacon, the idea of a book having national capital—displaying Canada as it should be, which in itself is subjective-became an essential part of the awards system. In his official letter to Gaskell in 1939, explaining that the judges had chosen Gibbon's Canadian Mosaic as the winner of the award for general fiction in 1938, Deacon notes how this component of the awards affected his decision: "[Canadian Mosaic] will contribute most towards the prestige of Canada in the minds of readers abroad and at home. They will also cause Canada to be understood better by her own citizens as well as foreigners. It was the consciousness of this special responsibility that made the deliberation of the judges longer and more searching than might have been" (Letter to Eric Gaskell, Official). This desire to use Canadian literature, and by extension Canadian art, to teach foreigners about Canada becomes an important part of the appeal for government sponsored patronage of the arts, as discussed in the next chapter. 


\section{Advice to Judges}

As chair of the Awards Board, Deacon both controlled and influenced the judging process. Deacon's letters to the judges occasionally speak to the C.A.A.'s purposes for the awards, which are two-fold: the awards serve both the author as well as the public. As Deacon notes: "We are trying to serve the authors by throwing an annual spot-light on the best book in each division, and to serve the public by indicating the best Canadian reading matter" (Letter to Ira Dilworth, n.d.). While enumerating the goals of the awards, Deacon is also aware of the awards' benefits. Only a decade after their creation, Deacon is acutely aware of both the cultural and economic capital that authors accrue from winning:

the inception of this award system was an effort to do something to assist authors to get attention in the home market, so that once each year a spotlight may be turned on the best Canadian books of the year. While we could not give money that we did not have, we could ensure publicity for a limited group of titles annually with the result of inducing people to purchase copies and thus increase royalties and enhance the author's reputation, which is his capital. (Letter to Charles Clay, 15 Oct. 1940)

This is a fairly heteronomous view of the literary field. For Deacon, the GG awards provide the public with the motivation to purchase books, which has the direct result of increasing an author's royalties - this is an economically driven agenda. The awards are also seen as being of service to other Canadian authors, for as Deacon notes, "in a mild way, we are establishing standards for writers. Other writers will be influenced in their 
aims by the kind of book [the judges] select" (Letter to Judges in Fiction Division). In this, Deacon is nodding towards what Roberts has termed national capital. Although not explicitly conceived in these terms, it is clear that Deacon is aware that the Governor General's Literary Awards serve a function in creating a national habitus ${ }^{24}$ by selecting "the best Canadian reading matter." As Deacon notes, this selection is a "public service rendered to Canada's cultural life" (Letter to A. W. Trueman). More explicitly, he notes that in awarding an award, "We say to the nation—not just to the writers: 'This is the best book ... produced in Canada in 1945. We have confidence in our writers and we think you will like this book"' (Letter to Leo Cox). As such, the Governor General's Literary Awards speak to the nation as a whole, showing Canada, and its reading public, what a unified national habitus should look like.

In reading his letters to the award's judges, it becomes clear that Deacon has a very clear idea of who the ideal reader of Canadian literature is, or at least, how he conceives of this ideal reader. This "John Public" is the average person—although noticeably male_- "an ordinary, intelligent reader," "a man of fair intelligence and reasonable taste. He is half-way between the infants who read comics and the Ph.D.'s" (Letter to Arthur Phelps; Letter to Ira Dilworth, n.d.; Letter to Arthur Phelps).

Accordingly, Deacon often describes what the ideal winner should, and should not, be:

We want a good, sensible, broad interpretation of "best book" — not an academic appraisal ... It must be both good and suited to the popular taste. . . . Don't

\footnotetext{
${ }^{24}$ Roberts's conception of the national habitus in relation to Canadian literary prizes draws on both Bourdieu's concept of habitus and on Charles Acland's discussion of Canadian cinema, who argues "It would be wrong to suggest that there is a single, unified, national habitus, but there has been an attempt to situate a set of dispositions as central to national character" (qtd. in Roberts 14). Roberts argues that "Although no 'single, unified, national habitus' operates in practice in Canada, national celebration of Canadian cultural products projects a unified habitus on the basis of shared nationhood," and that this unified national habitus rests on national capital. It is this concept of a unified habitus projected by cultural products that I am particularly interested in here.
} 
choose a very slight thing, no matter how excellent; don't choose what only Ph.D's will relish. Which one ought the bulk of Canadians to read if they knew about it? (Letter to Ira Dilworth, n.d.)

In this conception, Deacon is distinguishing the ideal award-winning book. It is neither the "highbrow" literature of the PhDs, nor is it the "lowbrow" literature of the comic book readers. It needs to be literature that the "average reader" can enjoy. The awards, however, are not simply meant to reward current popular fiction either. As Deacon notes, "We wish to avoid equally the rubber-stamping of best-sellers," (Letter to Arthur Phelps) and that the "winners ought to be good—have solid merits—but also have popular appeal" (Letter to Ira Dilworth, 5 Feb. 1946). He is aware of the book's readers as well, adding: "we do keep in mind that folks in Regina and Petitkodiak and Stroud, Ont., will actually lay out money for the thing with our approval stamped on it" (Letter to Leo Cox). Deacon's depiction of the ideal book is complex, and made more so by the fact that the judges did all not receive the same formulation of these standards. Each judge received a personalized letter, in which Deacon laid out his ideas for what a winning text should be. While many of these letters shared similarities, no two letters contained the exact same description.

When Deacon sent letters to the judges with his instructions on how to pick "the best book," he often included advice on which of the year's books the judges could disregard. This influencing of judges was usually prefaced with I "have no business to discuss merits with you" (Letter to Leo Cox), or "Without wishing to influence your decision" (Letter to Alexander Calhoun) which was then immediately proceeded by very 
pointed advice. Writing to Alexander Calhoun, a judge in the poetry category in 1946, Deacon writes:

Without wishing to influence your decision, there are a couple of points you should know.

1. Pratt, who has had two medals, absolutely refuses the award for this relatively slight work and his books should be ignored.

2. Where merit is equal or nearly equal, we feel that we are encouraging Canadian writers more by honoring new talent than repeating awards to the same people. For example, Birney, Marriott, Bourinot, have each had one medal. Consequently, if you are hesitating between one of these and some other, either for first, second or third place, I suggest you lean towards the new work. (Letter to Alexander Calhoun)

In this second piece of advice, Deacon is presenting his personal opinions about the award, as discussed earlier. The C.A.A. never made a policy against authors winning more than once. Even in his letters to judges, his advice does not remain consistent. In his letter to Leo Cox, also a judge in the poetry category in 1946, Deacon notes:

it is only fair to tell you that Ned [E. J. Pratt] absolutely refuses the award, and I think his poem written on assignment for Maclean's is too slight. So there is no particular reason for including him. However, our business is to find the best book, and if you think Ned's clearly is that, you must name him—but not if anything else is approx. as good.

Marriott, Birney and Bourinot have all had one medal each and there is no objection to a second award to any of these. Mary Edgar, F. R. Scott and Charles 
Bruce have not been honored and, if merits equal, one of these might be picked. But the vital job is to discover the best book. Never pass up an obvious winner merely because of one previous award. Ned only began refusing with his third medal — and he was right. It does him no more good. (Letter to Leo Cox).

In his comments to Cox, Deacon presents the same information-Pratt plans to refuse the award, and to avoid giving the award to the other previous winners if possible — but he also tells Cox that "the vital job is to discover the best book," and to vote for Pratt, or the other previous winners, if their work merits it. Cox, unlike Calhoun, was an active member of the C.A.A. National Executive, and would have been intimately familiar with the rules and policies. This suggests that Deacon's advice was not supported by the Awards Board, or the C.A.A. as a whole, and he changed his advice to suit the judge. Similarly, writing to all three judges of the fiction category in 1946, Deacon reminds them that Thomas H. Raddall had previously won the award, and that Duncan Campbell Scott's book is a reprint, and at 83 he "cannot be greatly assisted now in his career," concluding that "We therefore suggest discounting these competitors." Again, he does remind the judges that if "the supremacy is obvious - then the best book must be named" before concluding "the panel is strong and it is hoped you can find titles that serve better the general purposes of the Awards system, which is to aid writers in mid-career by the spot-light of publicity on one outstanding book yearly" (Letter to Judges in Fiction Division). Deacon also attempted to influence the judges by suggesting that only some of the books submitted were worthy of judging, although he does not mention titles or authors' names: "What we really want from you is an opinion as between the six novels of substance. I suggest you read them first and sample the others later," or "My opinion is 
that there are 3 contenders and one obvious winner and the job will take you not more than one hour, if that" (Letter to Margaret Clay; Letter to Watson Kirkconnell, n.d.).

The judges, however, did not always follow Deacon's unsolicited advice. In 1946, for example, Earle Birney won for his book of poetry Now is Time, despite having won the award four years earlier for David and Other Poems. Interestingly, in response to the win, Birney wrote to Deacon, noting: "I feel somewhat embarrassed about the award, as I think that it would be a good thing if a previous winner were automatically disbarred in order that newer writers would get a chance. What do you think?" (Letter to William Deacon, 26 Mar. 1946). Deacon explains to Birney that "Getting the medal before did weigh against you this time. You won in spite of that limitation. You see, we do consider these extraneous points where some equality exists and no critical misjustice is done" (Letter to Earle Birney, 29 Mar. 1946). In this exchange, it appears that Deacon is asserting his preference for penalizing previous winners as a rule of the awards. In reality, Birney won based on Deacon's point scheme, and there is no indication in the judge's voting or letters that they considered Birney's previous win against him, as Deacon suggests. In other words, Deacon's representation of events differs from the actual procedure, but he manipulates appearances to support his views.

\section{Awarding the Middlebrow}

Deacon's attempts to define what type of literature should win the Governor General's Literary Awards closely echoes what Margaret Widdemer, an American author, had defined as "middlebrow" literature a decade earlier. Widdermer's essay "Message and 
Middlebrow," published in The Saturday Review of Literature in 1933, was one of the first essays to discuss the term "middlebrow." In discussing the "reading public," Widdemer notes:

For unless we take the tabloid addict class as the norm, or the tiny group of intellectuals, what is the reading public but the public that reads; the men and women, fairly civilized, fairly literate, who support the critics and lecturers and publishers by purchasing their wares? And they are not highbrow or lowbrow; they are middlebrow. (433)

Although the comic book readers are replaced with "tabloid addicts," and the average reader is female and not male, Widdemer's classification of highbrow and lowbrow is very similar to Deacon's. For Widdemer, the middlebrow is epitomized by the "clubwoman," noting that "The club audience and its husbands, taking it by and large, is pretty much the reading public." It is worth noting that in Deacon's classification, the "clubwoman" that is essential to Widdermer's conception, is replaced by an explicitly male reading public. This was probably a conscious decision on Deacon's part, in response to the modernist critiques of the C.A.A.'s alleged bourgeois femininity. Interestingly, Widdemer's article begins by questioning the decisions made in the awarding of literary prizes. Widdemer wonders why the Pulitzer prize, which she had won herself in 1919, was now only awarded for literary merit, and not for "ideals in American life," as Mr. Pulitzer intended. In search for an answer, she turns to "the best critic" she knows, who tells her that "You cannot discuss art in terms of morality or immorality." To which Widdemer responds, "But actually, the reading public does discuss art—or at least its literary end—in those terms" (433). Widdemer's view of the 
middlebrow is necessarily a class of readers who are not served by literary awards that bracket questions of morality/immorality. Or, in other words, Widdemer believes that literary awards such as the Pulitzer no longer reward books that are actually read by the reading public.

Deacon appears to be acutely aware of the problems that Widdemer identifies with the Pulitzer. In an article in the Globe and Mail announcing the creation of the Governor General's Literary Awards, Deacon is skeptical of the success of the awards, noting: "it would be a serious mistake if the first awards were discouraging." $\mathrm{He}$ continues, "How easily that could happen is shown in the evolution of the Pulitzer Prizes. Here a prize specially set up for a novel of wholesome American life was given to Pearl Buck for a novel of Chinese life that the late Mr. Pulitzer would not have defined as "wholesome"” ("Annual Awards" 12). Deacon, from the award's creation, appears to be committed to the awards serving a specific purpose: bringing the "best" Canadian book to the attention of the largest number of Canadian readers. In this, Deacon's goals satisfy many of the aims of middlebrow projects in the mid-twentieth century, which were “aimed at making literature and other forms of 'high' culture available to a wide reading public" (Rubin xi). This attempt to please both the actual reading public, which Widdemer lamented was ignored by the Pulitzer, while still praising one book as the "best" book in Canada, explains Deacon's complex, and messy, description to judges of what constitutes a winning book.

Although Deacon's dismissal of "highbrow" literature equates well with other middlebrow projects of the mid-twentieth century, it appears that Deacon's concern was not entirely driven by an interest in average readers. Instead, it appears that at least part of 
Deacon's dismissal of "highbrow" literature stems from a personal distaste for the modernist poets. Although Deacon inevitably failed to completely prevent "highbrow" literature from winning GG awards, especially in the poetry category (an inherently autonomous genre), Deacon did attempt to use his power within the literary field to sabotage the avant-garde poets. This can be seen in his instructions to the judges of the GG awards, as well as in his role as literary editor of the Globe and Mail. Deacon, as an influencing agent in the field, consistently attempted to ensure that avant-garde poets, whose views on literature did not match his own, were not consecrated, making it more difficult for these autonomous producers to control the way that authorship is defined in Canadian society.

After agreeing to take on the editorship of the Canadian Poetry Magazine from Watson Kirkconnell in 1946, Earle Birney explained in a letter to Deacon how he planned to change the magazine. He notes that he hopes to get poems from: A.J.M. Smith, A.M. Klein, F.R. Scott, Charles Bruce, Ronald Hambleton, Anne Wilkinson, Ralph Gustafson, James Wreford, and Mario Prizek. These authors, for the most part, share one common factor: they were all modernists. In recruiting these writers, Birney was hoping to get "new blood" into the CPM. Birney notes that the old faithfuls would have to compete, that's all. My policy would be neither middle-of-the-road, left nor right, because I'm not thinking of it, as Kirkconnell did, in political terms; I want to publish the best poetry of this country and I don't give a damn who writes it so long as it's good; it must have a basis in craftsmanship and some spark of originality; my personal feeling is that even those ordinary prerequisites will exclude some of CPM's favorite contributors of 
the past. But that is why CPM has gone down hill. (Letter to William Deacon, 24 July 1946).

Birney's editorial policy, in only selecting "the best poetry" in the country, and refusing to think in "political terms," is an attempt to produce an autonomous poetry magazine, where all non-literary influences are bracketed off. In his correspondence with Deacon, Birney consistently insists on his editorial role being independent and separate from other concerns of the magazine, such as sales. In response to Birney's letter, Deacon assures Birney that neither he, nor anyone at the C.A.A., will interfere in editorial decisions of the $C P M$, "except that you must not call anybody a son of a bitch in print. That is a high policy matter." In true Deacon fashion, however, he could not help but share his opinion of Birney's decision to include these poets in the $C P M$. He notes I am surprised that the poets I fail to comprehend - fail to the point where I dare not attempt to review their books — seem to be exactly those you now wish to fill the pages of our magazine. I don't wish to debate the point. I merely express and echo your own opinion that a bunch of our Ph. D's, writing for other $\mathrm{Ph}$. D.'s with obscure allusions, will never win my readership. But I, as a poetry reader for decades, hardly glance now at our magazine, which has too few readers to be worth publishing.

If you can print anything in it (even the alphabet backwards) that will attract a large readership, then I'll cheer for you, whether I have brains and education enough to understand it myself. . . I can't make terms with Gustafson, F.R. Scott et al. They give me no pleasure and I refuse to read poetry that leaves me so blank. (Letter to Earle Birney, 9 Aug. 1946) 
Deacon is dismissive of the entire group of poets that Birney hopes to include in $C P M$, noting that they give him "no pleasure." 25 Importantly, this dismissal of an entire group of poets is based on his personal and subjective experience of pleasure and disregards the possibility that other readers might find pleasure in these poets' work. His reasoning for not reading these poets is almost verbatim the rationale he provides to the judges of the GG awards: these poets are writing "for other Ph. D.'s," i.e. the poetry is "highbrow," difficult, and purposefully inaccessible to average readers. Despite Deacon's selfdeprecation (he does not have "brains and education enough to understand" these poets), he is not an average reader. ${ }^{26} \mathrm{He}$ is the literary editor for one of Canada's most widely read newspapers, in which he "dare[s] not attempt to review their books." As such, his disavowal of these poets is not simply a personal rejection of their poetry, but is a boycotting of their work at a national level. As Earle Birney has noted, Deacon's "review[s] could launch or sink a new Canadian book" (Spreading 79). While Deacon's job as the literary editor of the Globe and Mail had no connection to his personal involvement in the C.A.A., his position on not reviewing these authors is counter to the C.A.A.'s mandate of promoting all Canadian authors - a mandate that he promoted during his tenure as President of the C.A.A.

\footnotetext{
25 Janice Radway describes judges of the Book-of-the-Month Club sharing an anger similar to Deacon's when encountering a text that "could not be read with the right kind of pleasure. ... [The judges] became furious, it seemed, by literary fiction that refused to acknowledge the legitimate desires and demands of readers" (67).

${ }^{26}$ This self-deprecation is most likely, in part, a result of a strong dislike of the academy. Deacons' biographers point to a number of instances where Deacon positioned himself against the academy. For example, they note that he was invited to teach a course at Ryerson in 1951-52 on the history of Canadian literature: "The object of the course was, [Deacon] said ... 'to prevent you, if possible, from reaching hasty, erroneous conclusions based on knowledge of a handful of books by a few writers of a particular group.' Implicit in that statement, and in the entire course, was a declaration against any academic canon of Canadian literature and, especially, against the supremacy of the Montreal group of poets" (Thomas and Lennox 221).
} 
Deacon appears to have been truthful when he tells Birney that he will not review the books of modernist poets. Of the 41 books in all four categories that were under consideration for the Governor General's Literary Award for 1945, the Globe and Mail published reviews of all but five. These reviews appeared almost exclusively in the Saturday Review of Books, ${ }^{27}$ which was edited by Deacon. Of the thirty-six reviews published, seventeen are explicitly attributed to Deacon, while another six have no byline, and may be assumed to have been written by Deacon as the literary editor. Of the five books not reviewed, the most conspicuous is Earle Birney's own Now is Time (which won the GG for poetry) and F. R. Scott's Overture. More telling, perhaps, is that while Deacon reviewed all but one of the books of fiction published in 1945, his byline does not appear on any of the reviews of the year's poetry. Even when he does publish reviews of poetry, he often fails to hide his derision. Deacon published a review of Ralph Gustafason's 1944 Flights Into Darkness written by Watson Kirkconnell. While the review itself is biting — "The style is modern to a fault. Erudite words are dredged up from the sludge of dictionaries ... On almost every page there are passages of cryptic incomprehensibility. ... If this poet would condescend to write for our understanding, instead of our bepuzzlement, his undoubted gifts of language would come into their own"- the most peculiar part of the review is a note that is attached at its conclusion, most likely written by Deacon. The note reads:

Note: Unable to grasp the meaning of Mr. Gustafason's beautifully printed poems, even after consulting several friends, we were about to discard with regret an equally handsome photograph [that accompanies the review] when we

\footnotetext{
${ }^{27}$ The reviews of James Edward Ward's God's Plenty and Mary S. Edgar's Wood-fire and Candle-Light did not appear in the Saturday Review of Books, but elsewhere in the newspaper.
} 
discovered the above review by the editor of the Canadian Poetry Magazine. Our thanks ... for permission to republish this comment on what we suspect may be an important book. ("More Light, Please" 19)

Even in publishing Kirkconnell's biting review of Gustafason's work, Deacon needs to further deride the book for its incomprehensibility. These reviews from 1945, taken as a whole, clearly demonstrate not only Deacon's preference for prose, but highlight the power that Deacon had over the modernists in his role as literary editor.

Deacon's disavowal of the modernist poets in his letter to Birney for being too difficult is only the beginning of Deacon's candid response. The letter continues: My opinion is that literature is an art of communication and when a reader of my experience and love of poetry can't understand what the author is saying, I quit reading. If I am missing some great truth, somebody else will phrase it more simply for my feeble intellect. I am disgusted with the whole crowd of poseurs. . . It is my belief that the persons in questions don't want an audience, beyond extremely narrow limits. (Letter to Earle Birney, 9 Aug. 1946).

Deacon reveals that his distaste of the modernist poets is not simply because their poetry is too difficult for his "feeble intellect." He is "disgusted" by what he views as the modernists' inauthenticity. While Deacon believed that literature should be bought and read, which might require authorial intervention into the marketplace to achieve, the modernists consistently showed disdain for any concern about economic interests. This struggle between Deacon and the modernists epitomizes the struggle for the dominant principle of hierarchization, as defined by Bourdieu. While Lord Tweedsmuir consecrated the C.A.A. by becoming its honorary president, few people had the amount 
of power to influence the literary marketplace in mid-century Canada that Deacon had. Deacon, as literary editor, and then as chairman of the Awards Board, had the literary legitimacy to consecrate authors, but equally important, he had the power to prevent authors from entering the literary field, by not reviewing their works, or by trying to obstruct their chances of winning the Governor General's Literary Awards.

\section{Conclusion}

This chapter has argued that the creation of the Governor General's Literary Awards was a way for the C.A.A. to influence the Canadian literary field by consecrating specific authors. Although the GG awards were presented as rewarding literary merit the judging of the awards was rarely this simple. In reality, judges were influenced by a number of conflicting factors: the relationship of the author to the C.A.A., the age of the author, the wealth of the author, the gender of the author, reader's reaction to the novel, the novel's "Canadianness," et cetera. Many of these factors lay outside of the literary field, and were driven by economic or political concerns. Even the name of the award - the Governor General's Literary Awards — owes its consecratory power to a political figure, and although his influence on the creation of the awards was limited, his name and position carry associated connotations. As a result, the activities of the C.A.A. during the 1930s and 1940s put forward an ideal of what Canadian literature should be, as the association viewed it: namely, middlebrow, anti-modernist, and pleasing to the reading public.

In 1954, the Awards Board became an independent body. The retiring chairman would appoint his or her successor, with this nomination "subject to the approval or veto 
of only the Governor General" (Stiling 4). The separation from the C.A.A. was essentially complete. As Stiling explains:

The Awards Board . . . is a self-perpetuating body. It is not democratic and cannot be if it is to perform its functions. Its appointment of judges and the classification of books must be non-partisan. The only connection between the Board and the Canadian Authors' Association is that the Association buys the medals and pays part of the administration costs. (4)

Separating the Awards Board from the C.A.A. had unintended consequences. After the Canada Council was established in 1957, the Awards Board approached the Council asking them to provide the Governor General's Literary Awards with cash prizes. The Council agreed, but only if the Awards Board would fall under the management of the Canada Council. The Awards Board agreed, and in 1959, the awards were no longer connected to the Canadian Authors Association. At the awards ceremony in 1960, A. W. Trueman explained that the Canada Council now ran the awards, and noted that: tribute must be paid to the sterling work which has been done by the Canadian Authors Association. It was this group that was largely responsible for the creation of the awards, and it was this group that supported the scheme in every way within its power. The Council now steps in to continue the excellent work which the Canadian Authors Association had so faithfully carried on for so long. Blessed with financial resources which are greater than those of the Association, the Council is able to do some things which the Association could not. (19) One of the things that the Canada Council was able to do was offer winners a cash prize of $\$ 1,000$. Some members of the C.A.A. were upset by the decision of the Awards Board 
to give the awards to the Canada Council, mainly because the C.A.A. had not been consulted. As Joe Holliday, editor of the Canadian Author and Bookman explains: "All around, unfortunately, the whole affair was sadly bungled. [. . .] Our only complaint is that neither the Awards Board or the Council people bothered to let the CAA know what was being discussed . . . or contemplated. The news about the cash awards and the G-G medals now being controlled by the Council came as a bit of a shock to CAA folks" (3). As I discuss in the next chapter, the Second World War brought with it the belief, which the C.A.A. supported, that Canadian artists needed government patronage to survive. When government patronage eventually arrived, through the Canada Council, the C.A.A. found that it had lost its ability to have a direct impact on the Canadian literary field. 


\section{Chapter Three: \\ The Rise of Government Patronage for the Arts}

By the beginning of the Second World War, the C.A.A. was focusing more attention on attempting to acquire government support for Canadian authors. The C.A.A. began looking at other countries' support for the arts as examples and found the perfect case study in Australia. In 1939, the Australian government began granting subsidies for the encouragement of creative literature in the country. The C.A.A. reported on this in the Canadian Author, explaining that these subsidies were created

to aid in developing a national literature indigenous to Australia, and of a quality to stand with the best that is being produced today in Europe and America. ... Our information is to the effect that the [Australian] Federal Government will grant subsidies up to a total of $£ 32,500$ a year . . . Administration of the fund will be entrusted to a Literary Council, nominated by the Fellowship of Australian Writers. (“Ottawa, Please Note!?" 6)

The article adds that this development was "Of vital interest to writers everywhere," and concludes by noting that "The C.A.A. is following these developments with close interest, in connection with certain plans at present under consideration by the National Executive. Probably no more significant gesture has ever been made by governmental authority in support of the creative arts." (“Ottawa, Please Note!” 6). While it is not clear what the "certain plans" under consideration by the C.A.A. were, it is evident that the C.A.A. planned to begin lobbying the Canadian government for similar support.

At the C.A.A.'s Annual Convention in the same year, Leslie Gordon Barnard echoed the need for government support in his presidential address: 
It is time that we saw this institution, this fellowship of Canadian writers, as worthy of endowment; one that would ensure the permanence and efficacy of our services in the interests of our native literature. I don't think authors are very successful money-getters! ... There seems to be money floating around for everything but the creative arts. We should have an endowment fund of at least $\$ 100,000$.

The question of Government aid enters here. I don't believe the government of this or any other land should be a sort of milch-cow, at whose unhappy udders every greedy interest should pull. But we have been very, very patient. We have seen every manner of creature, legitimate and illegitimate, shouldering their way to this fount of nourishment. And we have stood aside, a little meekly, shivering in the bleak winds of poverty, watching the spectacle of national nutrition, and scarcely raising the faintest "moo" of protest or appeal. ("Presidential Address" 7)

Despite Barnard's conviction that a government should not be a "milch-cow," he is equally convinced that the C.A.A., and by extension Canadian authors, are well past their due for government support. He is quick to provide a list of items that the C.A.A. would ask for if it had the government's ear:

Some sort of help in securing adequate publication and distribution of the best of the yearly crop of Canadian books.

A sympathetic and co-operative interest in the fortunes and difficulties of our national periodicals. 
A wise and selective encouragement, possibly in the way of scholarships, of the most promising of our writers, particularly the younger ones who at the moment have small inducement to write what is in them to write, without trimming their sails to catch the popular winds at home and favorable winds in markets not looking for the distinctively Canadian product.

To this we would add an investment of interest and tangible assistance in this organization of writers ... and in the two organs it sponsors, The Canadian Author, and The Canadian Poetry Magazine. Such an investment would yield, at small cost, incalculable national dividends. (emphasis in original, "Presidential Address" 7)

Barnard concludes his address by recalling the Australian government's plans to support Australian literature, noting that it is "a generous and magnificent adventure, the copying of which in Canada, even on a modest scale, would mean that at last the creative arts would be reckoned in this country as a vital item in our list of commodities for home consumption and export" ("Presidential Address" 7).

Almost two decades later, with the creation of the Canada Council for the Arts, the government had finally begun patronizing the arts in Canada. Within the first five years of the Council's existence, its funding had satisfied almost all of the desires set out by Barnard. The eighteen years between Barnard's address and the creation of the Canada Council saw a variety of attempts by Canadian authors to appeal to the government for support. This chapter traces that history—-the rise of government patronage of the arts in Canada. It begins by examining briefs submitted to both the Turgeon Committee and then the Massey Commission, focusing on how Canadian authors depicted their situation to 
these government enquiries. The chapter then examines the Massey Report, a fundamental document in the history of arts patronage in Canada, to discover how Canadian authors, and their situation, were understood. The chapter concludes by examining the early years of the Canada Council, with the aim of explaining which authorial endeavors were deemed worthy of support, and how authors, as a group, were supported financially.

Through this history, this chapter argues that in order to understand the rise of government patronage of the arts in Canada, it is first necessary to understand how authorship, as a profession, was understood. The establishment of government patronage for the arts required a number of interested parties — such as the government, interest groups, the public, and authors themselves - to state their understanding of the role of the author in the nation. By examining these various positions, it is possible to delineate the various ways in which authorship was understood. Although the two previous chapters have discussed the various ways that authorship was discussed and articulated in Canada between 1920-1940, the implications are now different. As this chapter shows, the debates around authorship during the rise of government patronage resulted in the competing conceptions of authorship coalescing into a single definition of authorship —at least from the perspective of government funding bodies. Importantly, by the time the Canada Council was established in 1959, it was more or less universally acknowledged that authors played an important and vital role to the nation, and were, as a result, worth supporting financially. While authorship was being officially acknowledged, as a profession, distinctions around who qualified as an "author"- and thus eligible for support — were being drawn. In this latter debate, which takes place behind the larger 
debate about the need for patronage of the arts, the C.A.A. found themselves disagreeing with almost everyone else involved. Since its inception, the C.A.A. had been lobbying for support for all writers regardless of their skill. Its critics, such as the Canadian Writers' Committee (C.W.C.), insisted on establishing a hierarchy of writers, and argued that due to the limited amount of financial support available funding should only be given to writers of merit and not to "hack" commercial writers. This debate about the artists' relationship to the marketplace is found throughout the rise of government patronage of the arts, and it is a debate that the C.A.A. more or less loses.

There is evidence that some authors within the C.A.A. itself also supported a hierarchical ranking of authors. For example, in 1945, Philip Child notes:

The membership of the Canadian Authors' Association seems to have divided by spontaneous fission into two groups who do not always view each other with passionate indulgence; these I shall call 'bread-and-butter writers' and 'litterateurs.'

The bread-and-butter writers, who earn their living (or part of it) by writing, accuse the litterateurs, who don't, of being impractical dilettantes, of talking airy-fairy moonshine about the values of art, and of looking down their noses at writers who have successfully stormed the fortress Satevepost [Saturday Evening Post]. The litterateurs, on the other hand, are said to accuse the breadand-butter writers of holding a low standard of success and of conniving at a mutual bond of mediocrity between themselves and their readers. (8)

Despite the fact that some members of the C.A.A. endorsed this division, the association as a whole consistently advocated for all authors, and avoided making any 
recommendations for funding that would be associated with a writer's merit. While this resistance to creating a hierarchy is seen throughout this chapter in the C.A.A.'s official statements to various government bodies and committees, it is also evident in the day-today activities of the association. For example, in its official publications, the C.A.A. often pointed its members towards literary markets that required material, regardless of its literary qualities. A 1945 article, for example, notes that mystery novels were selling better than ever, and encouraged authors to submit any manuscripts they might have to publishers:

In 1941, the average mystery novel sold only around 3,000 copies, and that was considered a pretty fair sale. Today, almost any mystery, even if not quite up to snuff, will sell at least 6,000 copies and frequently run to 15,000 copies. . . The war has created many new readers, and they have nearly all been "escape" readers, to whom this type of fiction appeals enormously. The writer with one or more mysteries in their system — besides the mystery of why he writes at allshould get them out and into the publishers" offices. ("Mysteries Boom" 4). This, and other articles like it, reinforces the association's belief that all authors deserve to be able to earn a living wage from their writing. For example, a similar article from 1943 explains that if authors want to "keep the ever-necessary cheques flowing [their] way," they should consider more unusual and non-traditional markets for writing ("Don't Overlook"). It is also worth noting that the hierarchy of authorship based on literary "merit" that modernist writers, as represented in the C.W.C., wanted to, and eventually did, establish produces a gendered hierarchy, as female authors were more likely to write genre-fiction, often for reasons of economic necessity, which was consistently considered 
to be without artistic or nationlist merit. ${ }^{1}$ As a result, the C.A.A's advocating for all Canadian authors, including "hack" commercial writers and writers of genre-fiction, resulted in the association indirectly supporting more women authors than it would have if it had supported a hierarchically-based system of merit.

\section{A Luxury Profession?}

Although the C.A.A. does not appear to have done any official lobbying of the government as a result of Barnard's 1939 address, the necessity of government patronage of the arts was continually repeated in the following years. In 1940, in the Globe and Mail, for example, William Arthur Deacon reported on the year's winners of the Governor General's Literary Awards, before bemoaning the lack of monetary support that accompanied the award. He notes that "There is no other country of a similar degree of culture without at least one system of substantial rewards for outstanding literary work, in recognition of its value to the nation" ("Three Best" 11). For Deacon then, at least one function of government patronage would be providing recognition for Canadian writersvery similar to one of the functions he saw the Governor General's Literary Awards

\footnotetext{
${ }^{1}$ Carole Gerson comments on the gendered nature of specific forms of publishing at the end of the nineteenth century in Canada, noting that the book "is historically a more masculine medium than is publication in a periodical," the latter of which "more easily accommodated women" writers (Canadian Women 67). One of the reasons for this demarcation was the ability to earn a living wage from writing. Gerson notes that although payment for writing was often seen as work, "an activity not traditionally sanctioned for "proper ladies" (68), writing did offer women "one of their few economically viable opportunities to work without blatantly transgressing their class status or their domestic commitments" (68). As such, if women were writing to make money, money was more easily made in periodicals. As Gerson notes, however, "While money was often to be made from periodicals, prestige and canonicity have been conferred by books." As a result, as Gerson's work shows, women writers were often excluded from the literary canon.
} 
performing. His solution was government patronage and the establishment of a Ministry of Culture:

Governments that spend millions to assist profit-making industries always remember the poor taxpayer when literary people want a few thousand dollars for writing - as though this were a luxury that a country can afford to be without. Even in wartime - perhaps more than ever in wartime-I say once again that we neglect this side of our national life at our peril. While neither public nor private funds are available for such purposes, a Ministry of Culture is overdue in Canada. ("Three Best" 11)

Deacon's concerns were quoted and supported in an article in the C.A.A.'s Canadian Author and Bookman. In addition, this article argues that:

In Canada, national consciousness in Letters and the Arts has been-is-limited by economic necessity. Professional authorship affords a precarious living to those whose talents might otherwise find freer expression if relieved of financial hardship.

We have no Pulitzer Prizes, no monetary endowment to encourage our writers to devote themselves vigorously to the service of Canadian literature. The pursuit of literature, with us, is regarded as a luxury profession—something of little or no account in the national economy. ("Luxury Profession" 14)

It is this view—-that Canadian authorship is a "luxury profession" with no impact on the national economy - that the C.A.A. needed to address before its demands for government patronage were to be taken seriously. It is worth noting that there is a contradiction in the C.A.A.'s position. On the one hand, the C.A.A. argues that because literature has such a 
negligible impact on the national economy, as Deacon notes, literature can act as a kind of compensation against the country's economic and military insecurity. On the other hand, the C.A.A. also argues that literature has a direct economic benefit to the nation, such as Barnard's claim that supporting the C.A.A.'s initiatives would provide "incalculable national dividends" (7). The C.A.A. continues to make similarly contradictory arguments to support government patronage over the next few years. As I discuss in the concluding chapter, it is the former argument that eventually convinces the state to fund culture, and it is not until the late 1970s that culture is seen as an essential component of the national economy.

Deacon continued publicly arguing for the necessity of government patronage for the arts. In a Globe and Mail article discussing "the future for native literature and the arts generally," Deacon bemoans the fact that despite the progress Canadian literature has made since 1939,

the larger public is still indifferent to the Canadian literary movement. And no Canadian book has ever yet exercised any decisive influence. Authors are not yet sufficiently encouraged to have produced the equivalent of "Uncle Tom's Cabin" or "The Origin of Species." We are still pioneering, still afraid of ourselves intellectually and emotionally. (“Gearing” 13)

Deacon found a like-minded critique in the words of Arthur Phelps, whose talk on CBC's Canadian Pattern echoed Deacon's concerns:

[Canadians] are often negative and derivative where we should be positive and creative. We lack the kind of consciously operative self-awareness and selfcriticism which makes apparent to us our virtues as well as our faults. Neither our 
essayists, novelists, dramatists, poets, nor painters have done adequately their interpretative and illuminating job for us, partly because they have not been encouraged to do any job for us. (Phelps qtd. in Deacon, "Gearing” 13)

Phelps continues, arguing that "if our desire for these spiritual assets is sincere, we must put up cash to foster the literary and artistic life of the nation-as other countries do.... somehow we seem to prefer our artists starving" (Phelps qtd. in Deacon, "Gearing” 13). This trope of the starving artist becomes one of the most dominant depictions of the Canadian artist in the debates surrounding government patronage. Phelps proposed creating a National Arts Board, backed by $\$ 250,000$ of public money to "revive the drama festivals, encourage ballet, support writers, sculptors and painters for specified periods, employ a director for various artistic projects in selected communities and universities” (Phelps qtd. in Deacon, “Gearing” 13). Deacon took delight in Phelps's ideas, only dissenting on one point: "Phelps himself is too modest, too discouraged. What we really need is a quarter million dollars of public money each and every year, and we must get a move on. There is no time left for fooling" (13). A watershed moment appears to have occurred at the beginning of 1944: Canadian authors, and Canadian artists more generally, were coming to the realization that government patronage of the arts was long overdue. Thus, when the opportunity to address this view arose later that year, Canadian artists came together to ensure that their collective voice was heard. 


\section{Artists March on the Turgeon Committee}

The Second World War concluded the Great Depression, during which one out of every three Canadians workers were unemployed (Struthers 208). The Rowell-Sirois Report, published in 1940, noted that while the federal government raised more taxes than the provinces, provincial governments were responsible for funding some of the most expensive services, such as healthcare and welfare. This disconnect between revenue and expenses made the problem of unemployment even worse. As a result, Canadians began looking to the federal government, and not the provinces, to solve the country's serious unemployment problem. And, as James Struthers notes, the Second World War "made Ottawa directly responsible for the nation's labourforce in a way that trade cycles could not, since mobilization and demobilization linked the federal government directly to the fate of the post-war labourforce. . . No one expected that veterans or unemployed war workers would queue up meekly in front of local relief offices [after the war]" (213). In the vein of stronger federal intervention, in 1942, the Canadian government set up a special committee on Reconstruction and Re-Establishment (commonly referred to as the Turgeon Committee) to consider the problems that would face Canada at the end of the Second World War. Although much of the effort around reconstruction was focused on economic reconstruction following the war, Kuffert argues that "dreams of co-ordinated goodwill or an enlightened democracy pervaded the discourse surrounding reconstruction" (69), and coins the term "culture of reconstruction" to describe this "environment and the accompanying complex of attitudes, opinions, and aspirations directed (especially during wartime) towards the achievement of a more satisfying 
postwar society" (emphasis in original, 69). This culture of reconstruction extended the conversation beyond the pragmatic questions, and "brought to light questions about the kind of society that Canadians could (or should) fashion once the war ended" (69). It is through this culture of reconstruction, and the Turgeon committee, that "critics of the cultural status quo" (66) hoped to begin a conversation about what a prosperous postwar Canada would look like in terms of culture. These critics, with their hopes of edifying the Canadian public through "highbrow" culture - through a belief that "Canadians could become a cultivated people if exposed to the right sort of influences" (Kuffert 67)would continue their lobbying throughout the next decade.

The established Turgeon Committee on reconstruction invited submissions from the public, and on 21 June, 1944 a collective of sixteen Canadian cultural societies, called the Canadian Arts Council (C.A.C.), appeared before the committee to present a joint brief, in an event known as the "March on Ottawa." The Canadian Authors Association was one of the sixteen cultural societies that signed the brief, which was entitled "Brief Concerning the Cultural Aspects of Canadian Reconstruction." Fifteen of the societies, including the C.A.A., also submitted supplementary briefs that highlighted their more personal requests. ${ }^{2}$ Deacon suggests that this date "may be remembered [in the future] as the beginning of coordinated artistic life in Canada" ("The Arts" 7). Richard Courtney,

\footnotetext{
${ }^{2}$ The sixteen societies were: the Royal Academy of Arts, the Sculptors' Society of Canada, the Royal Architectural Institute of Canada, the Canadian Society of Painters in Water Colours, the Society of Canadian Painter-Etchers \& Engravers, the Canadian Group of Painters, the Canadian Society of Graphic Art, the Federation of Canadian Artists, the Canadian Authors Association, a Committee of Musicians, the Canadian Society of Landscape Artists, the Dominion Drama Festival, the Canadian Handicrafts Guild, the Canadian Guild of Potters, the Toronto Arts and Letters Club, and the Société des écrivains canadiens. The Société des écrivains canadiens was the only society to not submit a supplementary brief.

Gregory Klages argues that the existence of these supplementary briefs suggests that the C.A.C. was not "particularly unified. . . Each of these additional briefs offered variations on a number of common themes, only some of which were reflected in the CAC brief. These briefs were also prepared at the same time as the CAC's brief was developed, suggesting the 'umbrella' brief cannot be wholly viewed as a distillation of the desires of the CAC's constituent organizations" (128-29).
} 
president of the Canada Council for the Arts from 1974-76, takes it a step further, arguing that the "the politicization of the arts [in Canada] began with the famous artists' march on Ottawa" (661).

The joint brief of the Canadian Arts Council begins by arguing that Canadian artists should have an opinion on the reconstruction of the nation, because "the creative arts stand in a key position in the economy of the whole nation" (House of Commons, Special Committee 331). The brief argues that all aspects of the Canadian economymanufacturing, construction, publishing, transportation, tourism, agriculture, miningnecessarily rely on the creative arts and artists, and that by supporting the arts, ${ }^{3}$ the government would be helping to secure "full employment in the post-war period" (331). This appeal to "full employment" is an example of how the C.A.C. used the language of the Turgeon Committee to make its brief appear to fit within the committee's mandate. The brief continues, however, to highlight its real concern - the need for government support of the arts - making the bold claim that "In no country is less consideration given to artistic matters than in Canada" (331). It continues:

Millions of persons living in Canada have never seen an original work of art, nor attended a symphony concert or a professionally produced play. Millions have opportunities neither for realizing their own talents nor for achievement in posteducational fields. On the other hand, thousands of professional, creative minds

\footnotetext{
${ }^{3}$ This claim is a rather large one to make, especially in the opening remarks of its summary. Since few, if any, of the cultural industries contributed directly to the economy of the country, the C.A.C. tried to show the various unseen ways in which the creative arts supported the economy. As such, it makes claims such as: "Manufacturing is as dependent upon design as upon capital, labour and raw materials. Construction ... is dependent upon the architectural arts. ... Transportation and tourism, agriculture, mining . . . are tied up less obviously, yet actually, through advertising, with artistic energy" (House of Commons, Special Committee 331). Left unstated is the fact that many of Canada's artists would be working in these various industries, in non-artistic capacities, because of their inability to make a living from their art.
} 
enjoy a field so limited that they are forced into activities unsuited to their talents. Thus energies are consumed in frustration. (332)

A fundamental difference between the various arts begins to appear, albeit probably unintentionally, in this appeal. The problem that needs to be addressed is the millions of Canadians who have no access to art; the art that Canadians are lacking, however, is a work of visual art, a symphony concert, or a professionally produced play. What is missing from this list, of course, are written works of art. There are two important differences here. The first is that the former group belongs to the realm of high culture, whereas writing, as an art, contains both lowbrow and highbrow literature. The second difference is that the product of the author's labour is a book, a play, a poem, but more importantly, it is a commodity. As such, the book is a self-contained object that is meant to be reproduced, distributed, and sold widely. So the imagined rural Saskatchewan farmer who had never seen a painting, heard a symphony, or experienced a dramatic performance, would have had access to written art, through periodicals, the press, and books themselves. Thus a divide is created: is the appeal for patronage of the arts an appeal on behalf of the Canadian public (which is lacking the "necessary" high culture), or is it an appeal on behalf of Canadian artists who are facing an unwelcome marketplace, dwarfed by the American marketplace? The brief of the Canadian Arts Council suggests that both problems can be remedied with government patronage. This rhetorical strategy, however, disadvantages Canadian authors.

The brief recommends a three-pronged approach for addressing the issue: the establishment of a government body, the building of community centres, and the encouragement of art in national life. Although the brief"s first suggestion is the "setting 
up of a governmental body for the supervision of all cultural activities" (House of Commons, Special Committee 332), it does not provide any details for what such a government body would look like. The brief does, however, spend considerable time outlining a plan for building community centres across the country, which would accomplish two goals. ${ }^{4}$ The first is that it would "achieve Canadian unity through the arts" (331) because "The arts, being universal, transcend racial, political and economic differences and class interests as well as sectional prejudices" (332). The second goal of these community centres would be to provide social benefits, by providing entertainment and education for "people in our rural and remote districts [who] suffer from loneliness and a sense of frustration," for "Being happier, our people will be more productive" (332). These two goals are optimistic - there is the implication that art serves a therapeutic function, which would unite the country, producing a happier and more productive workforce. Although the genre of the grant application requires such ambitious outcomes, it is unclear whether the coalition of artists truly believed in these statements. It is worth noting that the second of these goals- - helping to ease lonelinesswas something that the Canada Council would eventually take to heart. The proposal, however, was ambitious. The proposed plan would see twenty-five major centres built in large cities, fifty centres built in smaller cities, and five hundred centres built in the country's smallest communities. The largest centres would include all or some of the following: an art gallery, a workshop for "lithography, silk screen prints and mural paintings," a library, and a large auditorium for "drama, ballet, orchestra, and concerts"

\footnotetext{
${ }^{4}$ Kuffert identifies the construction of community centres as one of the desires of critics of mass culture, as they "encouraged active participation in cultural and recreational pursuits as preferable to other forms of leisure" (95). In other words, community centres would introduce citizens to "high culture" such as the theatre and the opera, instead of radio and television programs. It is not surprising then that the C.A.A. eventually rejects the notion of community centres during the Massey Commission.
} 
as well as films (334). The construction of these centres could be funded, the brief argued, for an estimated cost of ten million dollars.

The brief's third suggestion for promoting the arts in Canada is the encouragement of the arts in national life because, as the brief argues, "original thought and creative activity are major natural resources" (335). This is by far the broadest suggestion, and appears to include at least one suggestion to appease each society belonging to C.A.C. For example, the suggested ways to encourage the arts in national life include, among other measures: the conservation of parklands, housing and town planning, establishing a state theatre, establishing a national library, enlargement of the national gallery and national archives, providing increased copyright protection for industrial designs, and promoting Canadian arts abroad (335-38).

Although many of the brief's desires are ambitious, as a whole, the brief is a wellthought-out document. The artist coalition responsible for the brief made an argument for the role of the arts in the national economy, a justification that was easier for politicians to understand and support than earlier arguments made by the C.A.A., such as the argument that art is necessary for the country's self-discovery. This pragmatic approach is exemplified in the suggestion of the construction of community centres. Although the endeavour would be expensive, and the expected goals grandiose, the physical construction of these community centres would employ thousands of Canadians, most likely returned veterans. While the role of the arts in Canada was not part of the stated mandate of the Turgeon Committee, the artist coalition was able to make its requests fit within the Committee's purview of national reconstruction. Jody Berland notes that the Committee advanced a "a strategical connection between a cultural policy focused on the 
fine arts, and national defence," a connection that would become commonplace in early cultural policy in Canada. Berland argues that "Their goal was to elevate art's status as professional work, and to win government financial support for art production, on the basis of culture's potential contribution to national morale" (21). As such, this report began to circulate the idea that Canadian authors and artists were a vital component of the nation. In doing so, this rhetoric was beginning to change the public's opinion that authorship was a "luxury profession" unworthy of support.

The C.A.A.'s supplementary brief begins by noting the unique role that Canadian authors have played in nation building: "As so many of the works published are on Canadian themes, dealing with aspects of Canadian life in the various regions of Canada, Canadian authors can justly claim to have played their part in making Canada known to its own people and in thereby helping to unify the nation" (House of Commons, Special Committee 373). This statement, although employing rhetoric necessary for the genre of the grant, overemphasizes the role of Canadian authors. Although the C.A.A. hoped that its work would eventually make Canada "known to its own people," the market conditions for Canadian literature made this statement hyperbolic at best. This statement was followed by two additional recommendations for the improvement of the arts in Canada: "That travelling libraries be organized and circulated in rural districts throughout Canada, including books written by Canadian authors, and dealing with Canada" and "That collections of the best Canadian books available be sent to public libraries in other countries of the United Nations, to create a better understanding of Canadian Culture" (373). These two additional recommendations echo some of the suggestions presented in the third section of the main brief, such as the building of a national library and the 
sharing of Canadian culture with other countries. The C.A.A., in a similar fashion to the main brief, ensured that its requests were tailored to the mandate of the Commission by suggesting that its plan for a central library could be staffed by "discharged Service men or women."

The artists appear to have had public support for their brief. An article in the Globe and Mail, for example, supported the artists, noting that "The act to establish a department of reconstruction notes the need for best use of national resources. The delegation going down from the arts societies will hang their proposals on the very realistic peg that Canadian brains and hands - to think out, to design, and to make - are national resources, and they will claim that the arts hold a key position in the economic structure" (McCarthy 16). This support of artists is focused exclusively on their ability to be productive and contribute to the economy. As such, it ignores the artists' claim that art has the ability to strengthen the nation, by removing loneliness and boredom, so that other Canadians can be more productive. As mentioned earlier, in their appeal for government support, artists continually use two contrasting reasons for government support - the fact that art does contribute to the economy (often in vague terms), or the fact that art can act as a kind of compensation against the country's economic insecurity. Despite this conflicting rationale, the C.A.C.'s brief to the Turgeon committee did secure some public support for the idea of government patronage of the arts. This acknowledgment that Canadian artists are national resources is in direct contrast to the position that Phelps and Deacon saw authors facing only five years previously, when their pleas for patronage were ignored, because they were of no concern to the national economy. If nothing else, the Turgeon Committee gave Canadian authors and artists the 
platform necessary to begin to change this conception of their profession, as evidenced in McCarthy's comments. In a subsequent article, the Globe and Mail states that the artists "were, frankly, heralded as a 'long-haired' delegation, and came with as tight and tidy a brief as ever has been submitted to the committee by their opposites, representatives of business or labor" ("Group Asks" 11). Not everyone, however, was happy with the brief. William Arthur Deacon was particularly upset by sections of the brief, as he explains: Most conspicuous fault of the Brief, doubtless due to hurried draftsmanship, but too serious to pass uncorrected, lies in the wording of the first request, namely "the setting up of a Governmental body for the supervision of all cultural activities." Supervision means control, and if there is to be any public control of artists and their work we shall have copied the worst single feature of the Nazi regime. ... The creative intelligence, whether composer, writer or sculptor, must be absolutely free to create according to his ideas. Many things can be mass produced but never art. ... If the price of Government help is enslavement of the arts, then let us scratch along as we are. We dare not pay that price, which is ultimately a matter of selling your soul's integrity to curry favor with a Government that can help the artist to material success or make life impossible for him. Art is a sphere in which free enterprise must dominate all the time as the alternative to corruption, sterility and death—as well as the disgrace of not producing art. We cannot even compromise the issue. The plan fails if this point is not conceded. ("Arts in Canada" 7)

It is worth contrasting Deacon's position here to the position he took almost a decade earlier, when he argued for a similar government funded committee to oversee the arts. 
When he suggested the notion a decade earlier, he argued that if authors were to receive any government funding, it would require a public committee to "take over and administer the affairs of authors" because "Beside [authors], a drunken sailor is a model of thrift" (Letter to Albert Robson). ${ }^{5}$ Deacon's clear outrage at the Canadian Arts Council's suggestion of government sponsored art may be a result of observing what happens when it is taken to the extreme (as seen in Nazi Germany) as well as emerging Cold War debates around liberal freedoms, but also the strength of his belief in the necessary creative freedom of artists. Deacon's critique of the brief continues: "I am disappointed, as a writer, that so little attention was paid to literature. Apparently a National Library at Ottawa was enough for the makers of books, though more people are affected by books than any other form of art, except music possibly" (7). Deacon's argument continues, noting that as "Excellent as these ideas are, we need far more. A pension system is required ... The whole sphere of book design and manufacture was totally ignored, but is of utmost importance. So is the problem of copyright that tends to divert Canadian manuscripts away from the publishers and printers of Canada. Writers will certainly want to amend and greatly enlarge the meagre parts assigned them in the brief, in which painters had the greatest voice" (7). Deacon's critique of the brief clearly outlines the advantages and disadvantages of the C.A.A. joining the other artist societies in making this joint brief. The C.A.A. benefitted from the joint strength of all sixteen societies, allowing its request for government patronage of the arts to be officially heard for the first time. The consequence, however, was that the voice of Canadian authors had

\footnotetext{
${ }^{5}$ See footnote 8 in chapter two.
} 
been diluted. The C.A.A. would continue to lament the unfavoured position of the author during the subsequent appeals for government patronage.

Despite the vehemence of his critique, for the most part, Deacon supported the brief: "The idea as a whole is magnificent. There is not much danger of the writers failing to participate fully," although he is quick to add that "The fullest conceivable artistic freedom must be demanded and guaranteed before anybody dare acquiesce to the plan" (7). Deacon concludes by noting that "The Brief is a piece of pioneering without parallel in the cultural life of Canada and should so rouse public enthusiasm that the Government will see the wisdom of concurrence. Sincerest thanks go to the committee for its initiative and labors" (7).

The Turgeon Committee appeared to have appreciated the brief as well. After the brief was presented and discussed, John Ritchie MacNicol asked for a vote of the Special Committee to thank the artists' delegation, noting "They have made a very excellent submission which will be of great benefit to the members of the committee when we have an opportunity of thoroughly studying the different items of the submission" (House of Commons, Special Committee 355). This motion was seconded by Donald Alexander McNiven, who added "The discussion this morning has been stimulating and will engender a good deal of thought among the members of our committee" (356). The motion of thanks was unanimously adopted. Despite this, none of the brief's suggestions were included in the committee's final report. ${ }^{6}$

\footnotetext{
6 Bernard Ostry notes that "The Turgeon Committee was evidently impressed [by the brief] and recommended that the government set up either a department of cultural affairs or a non-political board" (55). George Woodcock echoes Ostry's claims (43-44). Gregory Klages, however, notes that "This recommendation, however, does not appear in the committee's second report, which was its final submission to the government" (81, footnote 34$)$.
} 
After the Turgeon Committee, the sixteen nationally organized societies of the arts in Canada passed "a resolution to continue the existence of the Committee which was set up in May 1944 to approach the Reconstruction Committee of the House of Commons" (“Arts Stand Mobilized" 24). The continuation of the Arts Reconstruction Committee resulted from a motion presented by Deacon, which stated: "That, whereas other matters may arise affecting the status and welfare of the arts as a whole in Canada, and it is therefore desirable that some liaison body be established to organize joint action promptly in an emergency, the representatives present form a standing committee representative of the various organizations" ("Arts Stand Mobilized" 24). In 1945, this collective officially formed the Canada Arts Council, which was renamed again in 1958 as the Canadian Conference of the Arts to avoid confusion with the newly formed Canada Council for the Arts.

Although this collective of Canadian artists was diverse, it was not without its limitations. For example, Maria Tippet notes that the societies that formed the Arts Council were "in keeping with the central Canadian, male-anglophone domination of cultural activity prior to the war" (173). As such, "Many of the country's major cultural organizations, institutions, and individuals were not represented" (173). Notably, there was no representation from dance or photography, few French-Canadian organizations, only two women's cultural organizations, and no representation from ethno-cultural groups or radical cultural organizations (173). The C.A.A., to an extent, is guilty of these charges as well. The association has consistently been stereotyped as being composed predominantly of women - those "Virgins of sixty who still write of passion" (Scott 39) - and its membership was, to an extent, a gendered hierarchy. Despite this, the 
National Executive was very much dominated by white, Anglophone men, some of whom actively prevented women authors from attaining positions of power within the association.

\section{Reporting on Authorship: Briefs Submitted to the Royal Commission on National Development in the Arts, Letters, and Sciences}

The newly formed Canada Arts Council was soon called upon again to represent Canadian artists in matters "affecting the status and welfare of the arts as a whole in Canada" (“Arts Stand Mobilized" 24). On April 8, 1949, the Canadian government ordered a Royal Commission on National Development in the Arts, Letters, and Sciences. This commission, more commonly referred to as the Massey Commission, was a watershed moment for government patronage of the arts in Canada: "with the establishment of the Massey Commission, the federal government assumed a new degree of responsibility for the cultural life of the nation" (Litt, Muses 36). As Paul Litt explains, the commission was the brainchild of Liberal Member of Parliament Brooke Claxton, who was responsive to pleas by Canadian artists for government patronage. Claxton tried for years to get the government to consider funding the arts in Canada without much success. While Mackenzie King was not responsive to Claxton's appeals, Claxton hoped King's successor, Louis St. Laurent, might view the proposal more favourably (Litt, Muses 14). With the help of the cultural elite, the promise of offloading politically sensitive issues surrounding radio and television broadcasting away from the 
government, ${ }^{7}$ and the potential for a reconsideration of federal involvement in universities, Claxton successfully convinced the government to create the Royal Commission. ${ }^{8}$ Litt argues that the "cultural elite," which was fundamental to the creation of the Massey Commission, "was not an exclusive clique, but a loose network of friendships and professional associations among leaders in academia, voluntary associations, and government. It was an elite ... in the sense that it was a definable, privileged group that wielded significant influence in Canadian society" (Muses 38). Importantly, this elite was not the actual producers of art (as represented by the C.A.C., for example) who had no real power in bringing about the Massey Commission- "artists were still outsiders in the lobbying game" (24). Instead, the elite were the true "influential group with an established stake in existing government institutions" (24). The only writers who would have belonged to this elite, as Litt defines it, would have been professionals— such as university professors — who also happened to write novels or poetry on the side. Many Canadian modernists were employed as university professors and would have belonged — at least tangentially— to this group. During the debates specific to authorship in Canada, the Canadian Writers' Committee, a group of Canadian modernist poets and authors, voiced the views of this cultural elite - that the government

\footnotetext{
${ }^{7}$ Litt notes that here were a couple of politically sensitive issues around broadcasting. One was inadequate government funding for CBC. The solution to the funding problem was raising an "unpopular licence fee," and as a result, the government was "eager to find alternative sources of revenue or to shift responsibility for an unpopular decision elsewhere" (Muses 24). The second problem concerned private radio stations. The current system "included a large number of private stations in a public system supervised by the CBC." These private radio stations began lobbying the government for a different regulatory system, and had managed to get Conservative MPs on its side. Therefore, "For the CBC's friends in government, a royal commission offered a way of providing an 'objective' and authoritative ruling on the issue that could vindicate the status quo without dragging the CBC into the mud of party politics" (25).

${ }^{8}$ For a detailed history of how the Massey Commission came about, see Litt's "The Origins of the Commission" in The Muses, The Masses, and the Massey Commission.
} 
should only support "highbrow" art and authors of "merit" - as discussed later in this chapter.

The Massey Commission, once created, was given "instructions for it to make recommendations upon the principles behind Canadian radio and television broadcasting, federal cultural institutions, Canada's relation with UNESCO, national scholarships, and the federal government's relations with national voluntary bodies involved in cultural affairs" (Litt, Muses 35). To accomplish this goal, the commissioners spent a year travelling Canada, holding public hearings in sixteen cities, and accepting over 450 briefs from public bodies and citizens, with over 1,200 witnesses appearing before the commission.

The C.A.A. took the opportunity to present a brief to the Massey Commission, and it reads as a manifesto outlining the importance of Canadian authors to the nation, and bemoaning their economic situation: "We are vitally concerned that this Commission should recognize the needs of creative artists as basic in the development of a Canadian culture ... Otherwise authorship must continue to be an ill-nourished orphan in Canada" (C.A.A., "Brief" 1). The brief—written on behalf of the C.A.A. by William Arthur Deacon (former President), C. Cecil Lingard (National Secretary), and Philip Child (Bursar) - repeats many of the claims the C.A.A. had been making since its inception. As such, the brief takes as a basic assumption that authorship is a profession, which the C.A.A. had always argued, while also emphasizing the profession's current state, as a collective of writers unable to earn a living wage from their writing alone. The brief continually highlights the importance of literature to the development of a uniquely Canadian identity, while emphasizing the power of literature to connect an otherwise 
diverse population; "Of all the arts, literature is the most effective cohesive national force" ("Brief" 3). To emphasize the belief in the connection between the nation and authors, the C.A.A. quotes Horace:

In vain their Chief's, their Sage's pride, They had no poet and they died;

In vain they schemed, in vain they bled, They had no poet — and are dead. (qtd. in "Brief" 2)

This type of melodramatic and hyperbolic rhetoric is prevalent throughout the brief: "if some practical benefits to the crafts do not result [from the Commission], the arts will suffer a severe defeat of a most discouraging kind" (“Brief" 9).

The problem, as presented by the C.A.A., is that Canadian authors cannot survive financially on their writing alone. The brief states: "Our aim is the improvement for the working writer at home by increasing his material rewards. We deplore the waste resulting from the fact that much of our best literature must be the fruit of hardly won spare hours, instead of the product of writers' fully devoted energies" ("Brief" 4). The solution to "the starveling state of the profession in Canada" (3) suggested by the C.A.A. is direct financial support for writers. Importantly, for the most part, the brief emphasizes that this support should be inclusive, "for the working writer," as opposed to being exclusive, based on some form of merit. Importantly, in this emphasis on the "working writer," the C.A.A. stressed how poor the working conditions were in Canada for all writers - even writers of middlebrow and lowbrow books. To survive on one's writing alone, and to publish in Canada, was a task that very few writers could accomplish, regardless of their genre of choice. The C.A.A. notes that for authors to receive 
comparable patronage to that received by painters, through the National Art Gallery, and as musicians, through the Canadian Broadcasting Commission, the Government would have to "become a publisher or retailer, or both, of books or periodicals, or both" (2). This avenue, however, "would encounter insuperable obstacles and is inadvisable." In the brief, the C.A.A. compares authors to other artists, and then separates itself off as facing unique problems. While left unstated, the reason for this difference is mostly likely caused by the C.A.A. grappling with the idea of the book as a commodity. Since the book is not a singular object (like a painting, or a performance) but is necessarily a massproduced commodity, the C.A.A. argues that it is not possible for the government to produce an equivalent National Art Gallery for books. Unlike other artists, authors do not create original pieces of art for sale; they produce manuscripts that get turned into books, which are then sold in multiples. This difference in the cultural product means that in order to support authors in a comparable way to other artists, the C.A.A. argues that the government would need to interfere directly in the marketplace, by becoming a publisher and distributor. In essence, the C.A.A. is acknowledging that the very nature of its craft makes it difficult to support adequately all authors, as a profession. In light of the difficulty the government would have in becoming a publisher, the C.A.A. asked the Commission to recommend instead that the government provide endowments for the Governor-General's Literary Awards, as well as scholarships for individual authors.

Briefs were also submitted by the Vancouver and Mainland Branch of the C.A.A., as well as the Victoria Branch. The brief from the Vancouver and Mainland Branch, and the branch's subsequent discussion with the commissioners, raised concerns that differed from the national C.A.A.'s brief. For example, the Vancouver branch's brief suggested 
that Canadian authors were leaving Canada as a result of the poor working conditions for writers. This contradicted the national C.A.A.'s brief, which boldly states: "no Canadian writer of standing has settled abroad for the past 27 years . . A patriotic impulse keeps these people at home and they are willing to stand the financial loss" (C.A.A. "Brief" 7). As well, the Vancouver branch's brief suggested that the government should establish awards for young, newer authors. This is in contradiction to the national C.A.A.'s brief, which advocated for supporting more established authors. On most points, however, the briefs expressed the same concerns. As the Vancouver Branch brief succinctly summarizes:

The best in Canadian letters is frequently buried or lost in the scuffle of making a living. Because there is no financial assistance in any way for struggling writers, quite often brilliant minds and great talent are lost to the world of literature and to our country, through the need for daily bread. (C.A.A. Vancouver and Mainland Branch, “Brief” 1)

The C.A.A.'s various briefs thus articulate the association's conception of authorship. This conception, at its core, is consistent with the association's stance since its inception: Canadian authors are labourers who are deserving of pay for producing their art because they help to produce a unique Canadian identity. This was the argument used when the C.A.A. lobbied for copyright changes in the early 1920 s, and is repeated in its brief to the Massey Commission.

The C.A.A. was not the only group of writers who presented a brief to the Massey Commission; the Canadian Writers' Committee (C.W.C.) also submitted a brief. As Sandra Djwa notes, the Canadian Writers' Committee was "a national group that had 
formed to present to the [Massey] Commission the views of those professional Canadian writers who now disassociated themselves from the Canadian Authors' Association" (262). During questioning before the Commissioners, Claude Bissell, one of the representatives of the Committee, explains:

The group consists, sir, of forty-two writers, poets and novelists, dramatists, critics and journalists. The group is bound together by certain common assumptions. First of all, that in the creation of a national literature we should maintain very high standards, and at the same time we are aware of our national heritage, we should be conscious also of more cosmopolitan trends around us. I think it is true to say, sir, that our group possibly represents a younger group, but I would stress the fact it is a group which has already achieved considerable distinction in the form of drama, poetry and the novel. (qtd. in Canadian Writers' Committee, "Minutes" 592-3)

Bissell further notes that its membership included Earle Birney, Dorothy Livesay, Len Peterson, W.O. Mitchell, P.K. Page, and F.R. Scott. In its brief, the C.A.A. identified itself as "the only nationally organized body of writers" (C.A.A., "Brief" 1), which confused some of the commissioners, as the existence of the Canadian Writers' Committee suggested otherwise. When questioned by Commissioner Levesque about the distinction between the two, Deacon stated that he had never heard of the Canadian Writers' Committee before. In the Canadian Writers' Committee's brief, its members identified the group as being "composed of professional Canadian writers" (C.W.C., "Brief" 1), and during questioning by the commissioners added that the group "represent[s] perhaps the most vigorous body of Canadian writing today" (Canadian 
Writers' Committee, "Minutes" 593). When the C.W.C. was asked about its connection to the C.A.A., Bissell explained that there was neither a connection nor any overlap in membership, although Len Peterson added that there was no reason that membership overlap could not occur.

A magazine article published in 1950 discusses the creation of the C.W.C. This article — which is unabashedly biased — compares the C.A.A., composed of "a bunch of old women," to the newly formed C.W.C., composed of the "Bright Newcomers" (Reyburn 12,24). The article, which supports and furthers the gendered stereotypes of the C.A.A., explains that the association is composed almost entirely of "old biddies," all of whom are amateur authors at best. The problem with the C.A.A., according to the article, is that it had no restriction on its membership:

The reason the [C.A.A.] now consists more of would-be than genuine writers is that its rules of qualifications have never been very strict. (In Edmonton they say that anybody who has written an obituary for the Edmonton Journal automatically qualifies for the Authors Association.) Len Peterson and his colleagues ... are making strict qualification rules ${ }^{9}$ the first requirement of their Writers' Committee. It is to be an organization made up of "professional Canadian writers" to help those writers in a practical way. (12-13)

This difference between the C.A.A. and the C.W.C.- the establishment of qualifications for membership — becomes one of the most important features of the two groups' differing views on authorship. For the C.A.A., authorship was something that was open to

\footnotetext{
${ }^{9}$ Reyburn does not state what these qualification rules are, but the argument that it will be an organization of "professional" authors suggests that having achieved some level of success would be necessary.
} 
all. For the C.W.C. authorship was something that needed to be closely guarded, and help should only be given to those "professional" authors who have met the standards.

Although it may not have been explicitly clear to the commissioners, the existence of the C.W.C. was based on the fact that its members fundamentally disagreed with the views of the C.A.A., such as the association's belief in supporting all authors. As a result, any overlap in membership between these two groups was unlikely. It is worth nothing that although the C.W.C. identified itself as "a group which has already achieved considerable distinction" its membership comprised of only forty-two authors; in comparison, in 1948, the C.A.A. reached its peak membership, with just over onethousand members. This is a considerable difference in representation. Further, the C.W.C. states that its members were "professionals," while the C.A.A. was composed of both amateur and professional writers. Paul Litt cites the contrasting opinions of these two groups as exemplary of the tension between emphasizing nationalism (the C.A.A.) and emphasizing cultural excellence (the C.W.C.) found within many of the submissions to the Massey Commission (Muses 110-11). And while the briefs of these two groups do have a number of important differences, they also have many commonalities, which are not accessible in Litt's narrative. If the membership of the C.A.A. and the C.W.C. together represents the majority of Canadian authors during the early 1950s, then the shared concerns found in both of their briefs offer insight into the state of authorship during the mid-century, as perceived by Canadian authors themselves.

Overall, the briefs from the C.W.C. and the C.A.A. share a common foundation. Both briefs bemoan the position of Canadian authors in Canadian society; authors are essential to the development of a uniquely Canadian identity — one that can help to resist 
the influence of American mass media - but authors cannot afford to live off of their writing even the "professional" authors of the C.W.C. As the C.W.C. brief notes "a considerable body of creative writing is essential to the continuing progress of Canada and her people," and "Canadians who write books seldom receive enough money from their sale to support themselves" (C.W.C., "Brief" 1, 3). These comments echo the C.A.A.'s concerns. The two briefs, however, also mention more specific problems with Canadian authorship. Both briefs acknowledge that American periodicals and books are flooding the Canadian market:

The greater part of the reading of Canadians in book or periodicals is still imported from the United States. (C.A.A., "Brief" 3)

There is so little the Canadian can do to offset the flood of American periodicals shipped into this country, the large number of radio programs fed in from the United States and the Niagara of American advertising. A mass of outside values are dumped into our cities and town and homes which run our lives, though we have no voice in the shaping of these values. (C.W.C., "Brief" 2)

Both briefs also specifically complain about the pay rate for authors at Canadian periodicals, noting that American periodicals pay substantially more. The briefs also criticize the C.B.C. for paying the writers of radio programming much less than the other labourers involved:

It is evident that the Canadian Broadcasting Corporation supplies livings to executives, technicians, actors, announcers and producers-none of whom are primary creators of art - and pays very poorly the writers whose works often 
reach vast bodies of listeners, and on whose ideas and creative skills a whole elaborate production may be built. (C.A.A., "Brief" 2)

$\mathrm{CBC}$ radio drama ranks with the best in the English-speaking countries. ... But: in this group of artists, the writer is the poor brother. He is paid proportionately much less than other artists. (C.W.C., "Brief" 3)

Finally, both briefs complain about the way in which Canadian authors are taxed, specifically that authors can only spread their earnings over a three-year period. In the end, these two briefs present a shared image of the state of Canadian authorship during the mid-century point: Canadian authors are essential to the developing nation, but they are neither paid appropriately, nor given the respect they deserve. The solution, both groups agree, is government-sponsored patronage.

As Paul Litt notes, however, the two briefs have a number of important differences. These differences are primarily concerned with the two groups' views on art's relationship to the marketplace. In other words, the difference lay in who, and who did not, qualify to be considered an "author." This difference of viewpoint is reminiscent of the criticism that the C.A.A. faced during the 1920s. The C.A.A. rejected a hierarchical positioning of authors and genres, arguing for a system that would support all authors. Although its brief is vague on the details of how such a system would work, the C.A.A. believed it should be involved in the decision process. It recommended financial support for the Governor General's Awards, which it ran, as well as grants for individual authors, to be granted by a board it hoped to have a seat on. The C.W.C., on the other hand, was more in line with the modernist view that art should be separate from the 
demands of the marketplace. Furthermore, in the C.W.C.'s brief, a clear hierarchy of authors is established. On top are the "creative writers" whose art is necessary to "build up [Canada's] culture" (3), and who are deserving of patronage and support. Below these authors are the "hacks:" "Inadequately paid creative writers [who] are inclined to give up eventually and become hack commercial writers in Canada or move to the United States" (4). These "hack commercial writers" are not worthy of patronage. Although not explicitly stated, it appears that "hack" writers, in the C.W.C.'s view, are writers who write solely for economic reasons. This descent from creative writer to hack, however, could be avoided by ensuring that creative writers received sufficient financial remuneration for their work. As the C.W.C. warns:

Canadians who write books seldom receive enough money from their sale to support themselves -- unless they happen to write a book which appeals to the American reader. But that has a bad effect on Canadian literature. It tempts too many writers to shape their material for the American market. They cease to be creative writers. (C.W.C., "Brief” 3)

And although the C.W.C. does acknowledge that Canadian readers are being flooded with American periodicals and books, "The fault is not America's, but ours" (2). The solution, therefore, is government-sponsored patronage of the arts and authors-but support of the right kind of art, and for the right kind of authors.

The C.W.C. listed "freedom of expression, of course"-in other words, creative freedom from market conditions - as the most essential way to give creative writing in 
Canada the necessary stimulus. ${ }^{10}$ The C.W.C. notes some of the ways in which this freedom was being impinged upon:

In general, editors, producers and directors who buy fiction and drama in our society regret that they cannot use a story or play of a better quality, but they say experience has taught them that it does not pay. Their cardinal rule of thumb is: "Give the public what it wants." Therein probably lies the basic conflict between the commercial editor, producer and director--and the creative writer. The editor, producer and director view writing as a mass-production product. Uniformity is basic. The creative writer on the other hand considers each piece he turns out as being more or less unique. (C.W.C., "Brief" 1-2)

There are two critiques to be found here. The first, as seen previously, is the distaste for the "mass-production product." The C.W.C., unlike the C.A.A., does not want to support the book as a commodity. Instead, it wants to support the author, so that she is able to create "unique" works of art. Part of this rhetoric is an attempt to validate the idea that poor sales have a correlation with "highbrow" art. The second critique presented by the C.W.C. is that editors and producers will only pay for what the public wants to read and listen to. This is problematic because the public does not know what it wants: "the public did not want Hamlet until Shakespeare created it. The Canadian public did not know it wanted Marie de Chapdelaine [sic] until it read it" ("C.W.C., "Brief" 2). In these comments, the C.W.C. is implying that the public needs to be told what they should listen to, what they should read, and what they should think is good. These comments are echoed later in the C.W.C.'s brief, when it argues that private radio stations should be

\footnotetext{
${ }^{10}$ The other two essential things needed to give stimulus to the creative writer were "an audience or public" and "an opportunity for the writer to work at his craft full-time."
} 
forced to play culturally elevating content: "Since there are a limited number of wavelengths available, it is incumbent on those to whom the privilege of using a wavelength has been granted, to 'push' regional culture as much as possible" (5). Importantly, the C.W.C. is advocating for the government control over the distribution of art that Deacon attacked as being akin to Nazism years earlier. Litt, in his study of the Massey Commission, identifies the C.W.C. as belonging to a cultural elite who hoped that the Massey Commission would bring about government-sponsored patronage of the arts that would educate the masses and improve their tastes—-whether the public wanted this edification or not—instead of simply supporting the Canadian equivalent of American mass-produced media.

The C.W.C. argued that editors and producers restricted Canadian "creative writers" by restricting the type of literature that they would publish or produce. The C.W.C. notes that "The popular periodicals in Canada still stick to formula fiction, which is very rigid in its requirements and in its taboos. . . . Commercial radio too is saddled with formula restrictions and taboos." (C.W.C., "Brief" 1). The C.W.C. elaborated on this complaint during questioning by the commissioners. Commissioner Neatby stated that the Commission had been told by representatives of the periodical press that "they were extremely anxious to get Canadian material, and they did a lot to train Canadian writers" and asked the representatives of the C.W.C. if this was true. Peterson responded, "I am sure that they are interested in training Canadian fiction writers, but they want to train them in their particular way, which clashes with some of the standards of creative writers. For instance, they like a happy ending. There are also some puritanical taboos. Oh, yes, there is another one too. You must have a plot. You must have things happening all the 
time" (Canadian Writers' Committee, "Minutes" 601). In these comments, it is evident that the C.W.C.'s complaint against editors and producers stems from the authors' inability to sell original, formally and thematically non-conformist, "highbrow" writing. This was doubly frustrating to the C.W.C., because not only would editors not buy their material, but it also meant that the public would not be able to read it, and they believed that it was the type of material that the public should be reading.

The C.W.C.'s brief outlines a very clear view of authorship. Being an author in Canada — or at least being an author who is acknowledged as such and funded appropriately — should be an exclusive club. This view of authorship was so restrictive as to exclude even members of their own group, particularly women. As Di Brandt notes, Dorothy Livesay, both a member of the C.W.C. and one of the most important figures in the development of Canadian modernism, has consistently been forgotten in important canon-forming anthologies and critical assessments of Canadian modernism (3-5). Brandt notes that this gender discrimination was even perpetrated by other modernist poets, like F.R. Scott (also a founding member of the C.W.C.), who omitted her from his 1936 anthology New Provinces (2). P.K. Page, another member of the C.W.C, and "a prime mover in the development of Canadian modernism," "suffered a critical fate similar to Livesay's" (6; 5). As such, the women writers of the C.W.C. were also ill-served by the modernist writers' rhetoric. As Laura Killian argues, modernism in Canada developed a "structural misogyny" through declarations that "denigrated 'feminine' and 'feminized' language/writing/culture and called for a new, hardened, vital, virile language and poetics" (87). 
As noted, the different conceptions of authorship held by the C.A.A. and the C.W.C., as articulated in their respective briefs, were based on a foundational disagreement regarding the role of the author in the marketplace. This disagreement, of course, is not new. The C.A.A. had engaged in similar debates since its inception. In particular, the differences between the C.A.A. and the C.W.C. were reminiscent of the debate between Robert Stead and the Manitoba Free Press, as discussed in chapter one. In that debate, Stead, as president of the C.A.A., defended the C.A.A's involvement in Book Week, arguing that Canadian authors were labourers deserving of fair treatment in the marketplace, and that books were commodities like any other. In return, he was criticized by the MFP for these "simply grotesque" ideas, for, as the MFP argued, "literature" was only produced by muse-inspired geniuses. Although the rhetoric had changed, the C.W.C.'s rigid hierarchy of authorship reproduced this argument, with "creative writers" akin to the muse-inspired geniuses. The C.A.A., on the other hand, stood by Stead's "weird idea" that "by taking thought and pains, [a person] can produce literature" ("Mr. Stead's Theory" 8). The C.A.A. wanted to see working writers receive a living wage.

Despite the difference in opinion between the C.A.A. and the C.W.C. concerning the role of the author in the marketplace, both of their briefs suggested that the government, through an arm's-length body, should provide fellowships or scholarships to Canadian authors. Importantly, both of these groups argued that the most direct and practical way the government could support Canadian writers was through direct funding, as opposed to supporting the other agents in the literary field, such as publishers. This suggests that both groups wanted authors to be supported, but they also wanted authors to 
be able to keep control over their writing. The C.W.C. suggested that the fellowships should "hardly be less than $\$ 2500$ for single writers and $\$ 3000$ for married" (C.W.C., "Brief" 6). The C.A.A. was slightly less generous, suggesting eight annual fellowships "of $\$ 1,500$ each for single persons without dependents, and up to $\$ 2,500$ for heads of families" (C.A.A., "Brief" 8). ${ }^{11}$ The C.W.C. suggested that the fellowship should be similar to the Guggenheim Fellowships. The C.A.A., however, argued that the scholarships should be awarded "only to persons who have published at least one book of merit or other literary work comparable thereto" (7). The C.A.A. also asked that it be involved in the judging process of these scholarships, instead of civil servants, teachers, or librarians, because these types of judges "would be less likely than working writers to judge accurately the literary potentialities of applicants" (8). Alongside scholarships, the C.A.A. also asked that the government provide $\$ 2,500$ in cash prizes to each winner of the Governor General's Literary Award, along with a $\$ 100$ honorarium to each of the award's judges. In turn, the C.W.C. advocated the creation of new awards for literature, with a cash prize of $\$ 1,000 .{ }^{12}$ For the judging of these awards, the C.W.C. recommended "that a body be set up from the Canadian Universities comparable to the Humanities Research Council” (C.W.C., "Brief" 6). During questioning by the commissioners, the C.W.C. explained why it felt university professors were the best judges for this award: Presumably, critical standards are more rigidly adhered to in the Universities and, secondly, there is the element of impersonality with respect to the awards which, in the hands of writers themselves, would tend to become involved in the personal

\footnotetext{
11 The division based on marital status takes as an assumption a model of the family with a single breadwinner.

12 The brief does not mention the GG awards, so it is unclear whether the C.W.C. envisioned these awards replacing the GGs or supplementing them.
} 
likes and dislikes; whereas there would be a greater possibility for the achievement of a certain objectivity. (Canadian Writers' Committee, "Minutes" 598)

The C.W.C.'s idea of a judging body differed from that of the C.A.A. in a predictable manner. In wanting to promote only appropriate literature, the C.W.C. wanted to ensure that the judges had the necessary "critical standards" to identify quality writing. The C.A.A., on the other hand, wanted to control the awards, as it could more accurately judge "the literary potentialities," however that was to be defined. Although the C.W.C. might have been attacking the C.A.A.'s running of the Governor-General's Awards when it suggested that awards "in the hands of writers themselves ... tend to become involved in the personal likes and dislikes," the C.W.C. complicates this accusation by suggesting that "there should be representation from other authorized groups [such as] the Canadian Authors' Association and possibly Canada Newspaper Critics" (Canadian Writers' Committee, “Minutes" 598). Interestingly, both of the C.A.A.’s suggestionsscholarships and cash prizes for the GGs - targeted already established authors. Its brief explicitly states that the "problem of creating a national literature" cannot be solved by "attract[ing] beginners, so long as the profession is so ill paid." Instead, "great good might be done by assisting established writers, who have demonstrated their abilities" (4). Although this hierarchy is not as rigidly defined as the C.W.C.'s hierarchy, the C.A.A. does appear to favour more senior authors over newer authors. The C.A.A., however, may have been trying to prevent more authors from entering a profession that was so poorly supported. 
There were a number of other cultural groups that submitted briefs to the Massey Commission that were also explicitly concerned with Canadian authors. The largest of these groups was the Canadian Arts Council, of which the C.A.A. was a member. ${ }^{13}$ At this point, the Council represented eighteen cultural groups, with a combined total membership of 10,000 Canadian artists. The C.A.C's brief deals with the concerns of all of its members, of which Canadian authors were only a small minority. Despite this, the conditions of Canadian artists at large were very similar to the conditions of Canadian authors specifically. The C.A.C.'s argument was simple: Canadian artists were, almost universally, underpaid; Canadians were unable to access Canadian art; Canadian artists were not known outside of Canada; and "Yet basic to the national development of the cultural life of any country is the success of its creative artists. This has been recognized by all countries throughout the period of civilization" (C.A.C., "Brief" 2). ${ }^{14}$ The solution offered by the C.A.C. came in the form of eleven detailed recommendations, such as increased financial support for the C.B.C., the construction of a National Library, and the establishment of a National Arts Board. Few of these recommendations were explicitly concerned with Canadian authors, although among the recommendations the C.A.C. did urge "the Federal Government to give assistance to [national voluntary art organizations],

\footnotetext{
${ }^{13}$ Unlike at the Turgeon Committee, a number of member organizations of the C.A.C. submitted their own briefs to the Massey Commission instead of simply attaching a short brief to the C.A.C.'s brief. In its own report, the C.A.A. argues that although it is a member of the C.A.C., "it is our belief that the needs of the writers should be considered separately and not regarded as a minor sub-division of Canada's cultural life" (C.A.A., "Brief" 1).

14 The Canadian Arts Council appears to not have had the full support of the press: "In another editorial, [the New Westminster British Columbian] quoted what it called the 'wail' of the Canadian Arts Council ... that writers cannot make a living in Canada, and commented: 'The Canadian people, evidently, are expected in those quarters to provide the artist with bread, with jam on it.' Recalling the days when 'the artist's business was his art, when poets starved in garrets and maintaining the body in sufficient strength to house the soaring mind was purely incidental,' the newspaper resented the assumption that the artist must not demean himself by writing for the market but must be left free 'to soar into the literary Empyrean where the atmosphere is too rarified for the common man to breathe"" (Ayre 25).
} 
recognizing their work as an essential part of a national programme in the arts" (C.A.C., "Brief" 17), and presumably the C.A.A. would fall in this category of a voluntary art organization. The C.A.C. hoped that its recommendations, if followed, would accomplish a number of objectives, such as "encourag[ing] the development of a significant body of creative achievement in all the arts," "creat[ing] a new attitude in Canadians towards the arts and letters," "mak[ing] available to every Canadian in every part of the country opportunities to understand, appreciate and enjoy the arts," and "giv[ing] artists a new rank and prestige in our society, with an income and security to match his position—an income that will enable him to reduce the time now given to teaching, commercial art, and other pursuits, and devote himself increasingly to creative activity" (C.A.C., "Brief" 26-27). Although overall the briefs submitted by the C.A.A. and the C.A.C. presented similar depictions of the Canadian artistic scene, the briefs did not always agree. The C.A.A., for example, notes that it

favour[s] the Arts Board recommended by the Canadian Arts Council, but only on the hypothesis that creative artists will have substantial representation thereon, and that literature will be adequately represented. We fear that a board made up of non-writers, however cultured, would swing the effective Government support away from the actual needs of cultural creators in the various arts and might go in exclusively for the building of community centres and recreational facilities that would be of no special use to working writers. The latter [i.e. working writers] are frankly concerned about means whereby the talented writer can live and produce - as their supreme contribution to the social and cultural life of the nation. (C.A.A., "Brief" 8) 
The C.A.A not only rejected the creation of community centres (which it openly supported a few years earlier during the Turgeon Committee), but it insisted again on the necessary role of "working authors" in any government created Arts Board, as authors are the only ones qualified to understand the needs of other authors. Again, the C.A.A. is aware of the difference between authors, and their unique problems, compared to other artists. After reading the C.A.A.'s brief, the C.A.C. submitted a memorandum to its own brief, speaking against the C.A.A.'s suggested involvement of authors on any created Arts Board, insisting that such a board would necessarily need to have equal representation from all artist communities as well as "non-professional or neutral members" (Charleabois 1).

Other smaller cultural groups and organizations submitted briefs to the Massey Commission that explicitly addressed the role of the author in Canadian society. These included briefs by: First Statement Press, the Fiddlehead Poetry Society, the magazines Here and Now and Contemporary Verse, the Fiction Writers of Saskatchewan, and the Société des écrivains canadiens. The briefs from both Contemporary Verse and Here and Now urged the Commission to recommend government patronage of Canadian little magazines, which published poetry, usually by "young poets.” The brief from First Statement Press continues this argument, bemoaning that "The public response to modern writing in Canada has been a tardy one" (First Statement, "Brief" 2), placing some of the blame squarely on the C.A.A., arguing that "Whatever its virtues, this Association has always been lacking in awareness of the great contemporary movement in literature. As a result it has alienated a very large number of the talented writers in Canada today" (3). Most of these associations felt that Canadians needed to be forced to appreciate good art, 
and in this way, their briefs were often more in line with the views of the C.W.C. than those of the C.A.A. The brief from the Fiddlehead Poetry Society epitomizes the belief that Canadians need to be forced to consume better art, in claims such as the following:

Canadians like stories and songs that are simple, direct, require not too much thought and offer an avenue from the reality which surrounds them. ... Such an attitude of willing suspension of disbelief towards whatever appeals to their desires is danger to the success of a democratic state. People who in normal times are susceptible to the glib promises of politicians will in abnormal times turn as readily to the Utopias of the Totalitarian Right and the Totalitarian Left. . . That most Canadians accept complacently what is offered them by the press, radio, publishing companies and films augurs ill for the future of Canadian freedom. (Fiddlehead, "Brief” 2)

This view - a narrow perception of the public as vulnerable to manipulation, which does not allow for a readership that critically interprets what it consumes-suggests that if the government does not provide patronage to the arts, and specifically the correct type of art, then democracy itself is at stake. ${ }^{15}$

Aside from briefs from the public and cultural associations, the Massey

Commission also requested studies on subjects relevant to the topics of the commission. Edward McCourt, a professor at the University of Saskatchewan, produced the study on “Canadian Letters," and his counterpart, René Garneau, wrote the study on "La Littérature" of Quebec. These two studies offer a strikingly different picture than the one

${ }^{15}$ It is difficult to determine how sincere this expression of fear truly was, and how much of it was a rhetorical ploy to gain government patronage. However, the fear of Canada losing its own cultural and political identity through consuming American mass media - thus threatening Canada as a nation — was found throughout the briefs to the Massey Commission, and was made explicit in the commission's final report. 
drawn by the briefs of the various cultural organizations. McCourt begins his summary by noting the "failure of Canadian writers to create a national literature of much significance to Canada or the rest of the world," and explaining that this failure "has, in the past half-century, been many times analysed" (67). McCourt argues that while the four "classic" explanations for Canada's failure to produce great literature-colonialism, the publisher, the reader, and the critic — "is each in some measure responsible," the full explanation must be sought elsewhere. McCourt argues that the problem lies with authors themselves.

McCourt, as an Oxford-trained scholar, as well as a writer, appears to belong to the cultural elite identified by Litt, and shares a similar hierarchical view of authors as the C.W.C., with very little patience for authors who decide to write for "slick magazines and Hollywood markets" (75). Even with this hierarchy in place, however, McCourt is critical of all authors, and lays a substantial part of the blame for the lack of a Canadian literature at their feet. Canadian authors, according to McCourt, have a number of problems. First, the Canadian author is not a leader, but "follows trends and tendencies first apparent outside his own country. ... [He] shows a deplorable tendency to climb aboard the bandwagon just when the parade is breaking up" (77). Second, Canadian authors are stuck with the Canadian character, which is "hardly likely to create great art" (77). But the most serious offense that Canadian authors commit is their "underlying assumption" that "as artists they are thereby entitled to freedom from the ordinary petty necessity of earning a living" (79). McCourt lays this blame despite the fact that a few pages earlier he noted that the Canadian reading public "does not buy enough books to make it even nearly possible for the Canadian writer to live on the proceeds of his work" (73). 
Although McCourt warns that he is not suggesting that "literature is the product of border-line existence in a garret room, only that in countries where great art flourishes we find many writers who are prepared, for the sake of what they write, to risk such an existence" (79). McCourt, however, also warns that "the creative arts" cannot be viewed "as spare-time pursuits" (80) and should not be practised by authors employed full-time in another occupation. In short, McCourt argues that if Canadian authors were less intent on comfort, and more willing to starve for their art, Canadian literature would have greater successes.

McCourt's counterpart, René Garneau employed a very different method in his study. His study is divided into two parts. In the the first part, he debates various methods of defining a national literature before deciding that to define a literature by its nationality has little value. Instead, he argues, literature should seek the universal in the Canadian. The second part of the study is a discussion of whether or not Quebec literature should aim to be autonomous from French literature. Garneau's main conclusion about the state of Quebec literature, which anticipates the Massey Report's conclusion, is that Quebec literature had not yet acquired the features of a national literature:

En essayant de situer les meilleurs écrivains canadiens de langue française en regard des conditions et qualitiés qu'il faut pour qu'une littérature soit dite nationale, nous avons vu que leurs oeuvres ne présentaient pas encore des caractères humains et universels qui donneraient une figure nationale à nos lettres.

Garneau agrees with McCourt that Canada has yet to produce a great national literature, although he notes that "Il y a progrès dans ce sens" (91). Garneau, however, does not 
discuss the various social and economic problems that have contributed to this failure.

Instead, he focuses on what characteristics and features such a literature should contain.

Garneau's view echoes the modernists' view that great literature should be neither overtly patriotic nor regional, nor use outdated styles, but should be read and recognized abroad. It should be written in contemporary styles, and should attempt to help us understand "1'homme." Garneau and McCourt were both discouraged by the current state of Canadian authorship, and they both endorsed the government supporting a specific type of Canadian author.

\section{"Culture has this in common with underwear and fur coats—it costs money": 16 The Massey Commission's Report}

After holding 224 meetings, reading 462 briefs, and listening to presentations by over 1,200 witnesses, the Massey commission submitted its 500-page report to the government in June 1951. The report is divided into two parts. The first part summarizes the various briefs and reports submitted to the commission, separated into chapters for each area under consideration by the commission, such as "Music," "Literature," and "Ballet." The second part of the report lists the commission's recommendations to the government. The report begins with the well-known appraisal of Canadian culture in relation to American influence. The report summarizes this chapter, "The Forces of Geography," by noting: American influences on Canadian life to say the least are impressive. There should be no thought of interfering with the liberty of all Canadians to enjoy

\footnotetext{
${ }^{16}$ Quotation is from a satirical summary of the Massey Report, "Little Man Letting Down the Longhairs."
} 
them. Cultural exchanges are excellent in themselves. They widen the choice of the consumer and provide stimulating competition for the producer. It cannot be denied, however, that a vast and disproportionate amount of material coming from a single alien source may stifle rather than stimulate our own creative effort; and, passively accepted without any standard of comparison, this may weaken critical faculties. ... We must not be blind, however, to the very present danger of permanent dependence. (Report 18)

This chapter of the report attempts to reinforce the importance of not interfering with free trade between the two countries, while simultaneously reminding readers of the "invasion" of American content, some of which is "positively harmful" to our children, and "threaten[s] to submerge completely our national product" (Report 18, 18, 17). This fear of American publications drowning out any original Canadian content appears throughout the report's summaries.

The report summarizes all of the submissions on the state of Canadian literature in six pages. The chapter's first sub-title is "Is there a National Literature?" to which the report answers with an unequivocal "no":

Is it true, then, that we are a people without a literature? . . Both [of the authors of the studies on French and English literature in Canada] agree that neither in French nor in English have we yet a truly national literature.... Not only the critics but the briefs agree that Canadian literature has not yet achieved the status of a "national literature." (222-4)

Unsurprisingly, the report lays most of the blame for this lack of a national literature on America. As the report states: 
Without taking sides on this matter we do think it is important to comment on the efforts of those literary groups belonging to various schools of thought which strive to defend Canadian literature against the deluge of the less worthy American publications. These, we are told, threaten our national values, corrupt our literary taste and endanger the livelihood of our writers. ... Immunity from alien influences would not, of course, be sufficient in itself to create a national literature; but it would at least make possible a climate in which the Canadian writer would find himself more at home, where he would be better understood, and where he would find the opportunity for more frequent spiritual contacts with a society which would be more fully Canadian. For if our writers are uncertain of the road ahead, their uncertainty, it seems, is derived from the general confusion in a society with no fixed values and no generally accepted standards. (225-6) Although the commissioners refuse to "take sides," the report clearly lays the blame on the "invasion" of American books and periodicals. This "invasion," we are told, prevents the Canadian writer from finding "himself at home," as Canada is a society with "no fixed values and no generally accepted standards." The report's emphasis on the impact of American publications on Canadian writers is not an accurate summary of the main concerns raised in the briefs submitted to the Commission, which placed little concern on the influence of American publications in the Canadian market.

More surprising, however, is the Report's complete absence of any mention of the fact that Canadian writers unanimously agree that they cannot live off of their writing alone. This condition of the Canadian author, one of the few facts that the briefs all agreed upon, is completely absent from the report. The closest acknowledgment the 
report provides of authors' living conditions is the statement: "In Canada, it seems, the cultural environment is hostile or at least indifferent to the writer. If so, the interests of literature can best be served by improving conditions of work for our authors" (226). Even the suggestion that Canadian literature can be best served by "improving conditions of work" for authors is preceded by "If so," which provides for the possibility that Canadian authors might not need this type of support. The report finishes its summary of literature in Canada by stating:

If we have properly understood what we have been told, the Canadian writer suffers from the fact that he is not sufficiently recognized in our national life, that his work is not considered necessary to the life of his country; and it is this isolation which prevents his making his full contribution. It seems therefore to be necessary to find some way of helping our Canadian writers to become an integral part of their environment and, at the same time, to give them a sense of their importance in this environment. (Report 227)

Most of the briefs submitted to the Commission would agree with the suggestion that Canadian authors, and their work, are not "sufficiently recognized in . . . national life." However, the briefs from the C.A.A. and the C.W.C. hoped that this problem of recognition would be solved through material support for writers, allowing them to write, be published, and hopefully, be read. Instead, the Massey Report suggested that the lack of recognition was itself the problem. The proposed solution, however, of finding "some way of helping our Canadian writers to become an integral part of their environment" is surprisingly vague. Despite its vagueness, the comment that it is "isolation which prevents [the Canadian author] from making his full contributions" appears to have been 
taken to heart by the Canada Council, once it was eventually established, as a number of its initiatives were aimed at solving this uniquely Canadian "problem."

Although the report's summary of Canadian literature fails to explicitly mention the inability of Canadian authors to earn a living wage by writing, in its recommendations, the report puts money at the forefront of aiding culture in Canada. In the introduction to Part II of the report, in which the commissioners lay out their recommendations, they note:

If we in Canada are to have a more plentiful and better cultural fare, we must pay for it. Good will alone can do little for a starving plant; if the cultural life of Canada is anaemic, it must be nourished, and this will cost money. This is a task for shared effort in all fields of government, federal, provincial and local. (Report 272)

The rest of the report lists the commissioners' various recommendations on how the federal government should spend money to "have a more plentiful and better cultural fare." None of the recommendations exclusively or explicitly address Canadian authors. In fact, writers are rarely mentioned in Part II of the report. In a section on national scholarships which the commission recommends, the commissioners note: "It seems to us to be undoubtedly in the national interest that certain of our artists, of our writers and of our musicians, for example, should receive advanced training and experience in countries abroad" (363). As a result, the commissioners recommend that "there be created a system of grants for persons engaged in the arts and letters (including broadcasting, films and the press) for work and study either in Canada or abroad" (363, emphasis in original). While the commission does recommend grants for Canadian artists, they require the 
artists to leave Canada. These grants would then be comparable to the Guggenheim Fellowships, for which Canadian authors were already eligible. The C.A.A. and the C.W.C., in their respective briefs, both requested that any grant programs recommended by the commission should not simply emulate the Guggenheims, as these required the artist to leave the country, which was not always productive or useful for authors. This request by Canadian authors was clearly ignored, although this requirement to have grant-winners leave Canada fits well within one of the larger goals of the cultural elite of using Canadian culture as a foreign policy tool.

The only other recommendation in the report that would have had a direct impact on Canadian authors was the well-known recommendation of establishing the Canada Council. The commission recommended:

That a body be created to be known as the Canada Council for the Encouragement of the Arts, Letters, Humanities and Social Sciences, to stimulate and to help voluntary organizations within these fields, to foster Canada's cultural relations abroad, to perform the functions of a national commission for UNESCO, and to devise and administer a system of scholarships. (377, emphasis in original)

The commissioners explained that "with but two or three exceptions" all of the various voluntary organizations that appeared before the commission expressed some kind of interest in the creation of a national body that would oversee culture in the country (370). One of the functions that this recommended Council would serve, the commissioners suggested, was financially supporting the "many voluntary bodies whose work is of national importance but whose resources are inadequate for their growth or even for their 
survival" (372). This would have included the Canadian Arts Council, and potentially the C.A.A. as well. Aside from this recommendation, the only other mention of Canadian writers in association with the creation of the Canada Council appears when the commissioners disagree with the C.A.A.'s brief:

We have given great care, in our deliberations, to the many submissions made to us concerning the appropriate composition of such a Council, notably from Canadian artists and writers who have urged that a Council be established which would be representative of their professional organizations. With this view we are unable to agree. We judge that the members of a policy-making body to be concerned with many complex aspects of Canadian life should be free to consider all problems before them without the restraints which normally would bind them too closely to the organization or to the group which they would represent. . . . This is not to say, however, that a Canadian artist, a Canadian musician, a Canadian writer, or a Canadian scholar should not serve on the Council; if he does, however, he should sit in his capacity as a distinguished and public-spirited Canadian citizen rather than as the representative of a particular organization or institution, or of a specialized art. (377)

This rejection of the many cultural societies' hopes to be directly involved in the recommended Council is not solely targeted at the C.A.A. A number of volunteer organizations had recommended that they should have some sort of direct representation on the Council. It is not surprising then that the commissioners did not follow these suggestions - it would have been impossible to appease all of the various groups that felt entitled to a position on the Council. What is interesting about this recommendation, 
however, is that the commissioners did see a potential place for Canadian artists on the Council, but as "distinguished and public-spirited Canadian citizen[s]." As such, artists were desired because of their membership within the collective of "public-spirited" citizens, rather than as representatives of their art.

Despite the widespread media coverage that the report received, and its lasting impact on the national mythology of government-sponsored culture, Paul Litt argues that the report actually had a small impact as a catalyst for institutional change: "It is romantic to think that the Massey Commission had a revolutionary impact" (Muses 245). Litt notes, for example, that "Only 12 of the report's 146 recommendations were implemented two years after its release" (237). Litt also questions whether the recommendations that were enacted "after a time-lag" can be credited to the report: "Were improvements that came ten or twenty years later the result of the commission's influence?" (246). Litt continues:

the Canada Council is the most obvious and most important case in point. The Council idea was around well before the Massey Commission came into being ... Moreover, it was six years following the Massey Report and only after a conjunction of happy coincidences that the Canada Council was created. This was hardly a case of the Massey Commission having an "immediate and transforming effect." (246-47)

While Litt questions the importance that the report has been given in the history of Canadian cultural development, ${ }^{17}$ he suggests that the report's lack of impact is

\footnotetext{
${ }^{17}$ In particular, Litt is critical of Claude Bissell's claim in The Imperial Canadian that "No other Canadian commission, before or since, has had such an immediate and transforming effect" (qtd. in Litt, Muses 245). He also cites Blair Fraser's The Search for Identity and Robert Fulford's foreword to An Introduction to the Arts in Canada for making similar claims (308, endnote 1).
} 
not surprising when [the] original reasons for establishing the commission are taken into account. The areas which got attention [such as radio broadcasting] were those which had prompted the creation of the commission; both were political quagmires into which the commission had been dispatched to chart a path that the government could safely follow. The other issues had originally provided camouflage for this venture and were forgotten when they were no longer useful. (243-44)

It appears that Litt is correct, at least in relation to the direct impact that the report had on the livelihood of Canadian authors. Yet, even if the government's concern with the Canadian writer was simply a "camouflage" for its real agenda, the Massey Commission forced Canadian authors to articulate their shared concerns for the profession, and to express them publically.

\section{The Canada Council for the Arts}

The "Act for the Establishment of a Canada Council for the Encouragement of the Arts, Humanities and Social Sciences" received royal ascent on 28 March 1957, effectively creating the Canada Council for the Arts. The Act defined the objects and powers of the Council, which were "to foster and promote the study and enjoyment of, and the production of work in, the arts, humanities and social sciences." The Act granted the Council a fairly wide-ranging mandate. The Council could assist both organizations as well as individuals; it could support endeavours in Canada, or send artists abroad; it was empowered to help scholars through a variety of scholarships; and its mandate covered 
the arts, the humanities, and the social sciences. Although Canadian authors had requested, and supported, the creation of such a Council through their various submissions to the Massey Commission, they ended up receiving the short end of the stick after the Council was created.

In the first decade of the Council's existence, "writing" was the area of the arts which received the least amount of funding - this category included funding for authors directly, as well as support for other agents in the literary field, such as publishers. Table 4 and Table 5 represent this information in two ways. Table 4 lists how much money, in thousands of dollars, the Council spent each year during its first decade on "writing." The table also lists the per cent that this funding represents of the Council's total expenditure each year; "writing" always receives less than ten percent of the Council's total expenditure, and is always the category of the arts to receive the lowest amount of funding.

\begin{tabular}{|l|l|l|l|l|l|l|l|l|l|l|}
\hline & $1957-58$ & $1958-59$ & $1959-60$ & $1960-61$ & $1961-62$ & $1962-63$ & $1963-64$ & $1964-65$ & $1965-66$ & $1966-67$ \\
\hline $\begin{array}{l}\text { Thousands } \\
\text { of dollars }\end{array}$ & 48 & 90 & 98 & 112 & 123 & 104 & 79 & 114 & 150 & 314 \\
\hline $\begin{array}{l}\text { Per cent of } \\
\text { total } \\
\text { spending }\end{array}$ & 6.4 & 6.3 & 7.6 & 7.9 & 8.2 & 7.1 & 5.5 & 7.7 & 4.4 & 7.3 \\
\hline
\end{tabular}

Table 4: Amount of Grant Money Given to "Writing" by the Canada Council"

Table 5 displays the percentage of funding each area of the arts received from the Canada Council during the first decade of its existence. Not only is writing the area of the arts that received the smallest amount of funding, it received substantially less funding than other areas. Both dance and visual arts received twice the amount of funding as that

\footnotetext{
${ }^{18}$ Data from: A History of the Canada Council.
} 
allotted to writing, while theatre was given almost four times and music over five times the amount of funding.

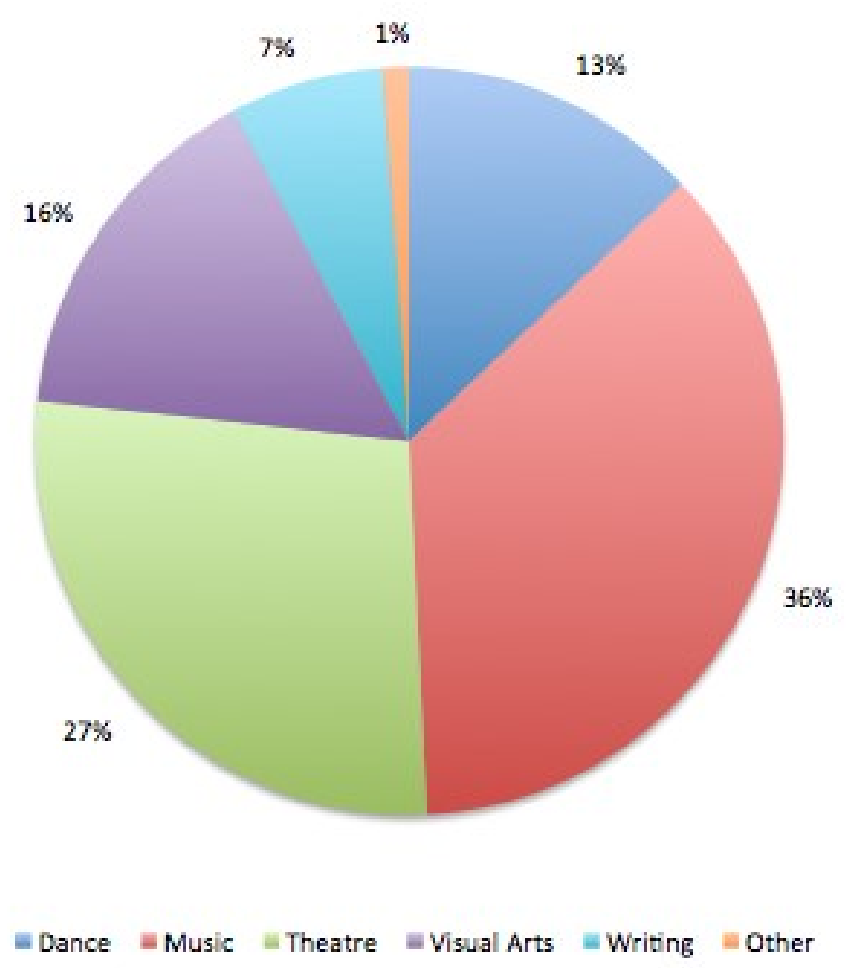

Table 5: Distribution of Canada Council Funding from 1957-1967 19

The Council's mandate from the government did not dictate how the Council's funding was to be divided among the arts. Instead, the Council had to decide for itself which of the arts needed the most support. There are probably a few reasons why writing received such a disproportionate amount of financial support. For one, some of the other arts, such as dance and theatre, required substantial amounts of funding to produce a single performance, or to tour a performance around the country. A second reason that writing

${ }^{19}$ Data from: A History of the Canada Council. 
most likely received less funding than the other arts was foreseen in the C.A.A.'s brief to the Massey Commission. In its brief, the association noted that for literature to receive the same support as the other arts the Government would have to "become a publisher or retailer, or both, of books or periodicals, or both," but the C.A.A. concluded that such a plan "would encounter insuperable obstacles and is inadvisable" (“C.A.A. Brief” 2). As such, it was difficult to fund writing in the same ways as the other arts.

\section{"Not Another Art Factory"}

During the opening proceedings of the Canada Council in 1957, Brooke Claxton, Chairman of the Council, explained how the Council was organized:

The Council consists of seventeen men and four women drawn from every province in Canada. For the most part they are not specialists. A moment's consideration will make plain the reason for this. No working board would be big enough to hold even a sample of the leading workers in all the various branches and schools of the arts, humanities and social sciences. (10)

This description of the Council is surprisingly vague, listing the twenty-one members as "men and women of broad interests and wide experience," whose qualifications appear to include the fact that they are "all very busy people." Despite its vagueness, it would appear that this composition does not match the desired composition put forward by either the C.A.A. or the C.W.C. during the Massey commission. As discussed earlier, the C.A.A. had asked that it be involved in the judging process of these scholarships, instead of civil servants, teachers, or librarians, because these types of judges "would be less 
likely than working writers to judge accurately the literary potentialities of applicants" (C.A.A., "Brief" 8). In turn, the C.W.C. had suggested that university professors were the best judges for the task of awarding scholarships, as "critical standards are more rigidly adhered to in the Universities" (C.W.C, "Minutes" 598). The difference between how the Council was actually composed and how Canadian authors wanted it composed is most likely due to the fact that the Council did not have separate committees for each category of the arts. Therefore, the Council was originally composed of generalists who could vote equally on the merits of a grant for an author as for a musician or painter. As a result, the Council argued that non-specialists were a necessity.

When the Canada Council was created, the government allocated one hundred million dollars for its work. Fifty million dollars was earmarked to create the University Capital Grants Fund. The other fifty million dollars was used to create the Endowment Fund; it is this money that the Canada Council used to support the arts. Only the revenue from the Endowment Fund could be used each year, which gave the Council approximately two million dollars per year to allocate. From the beginning, the Canada Council knew that this funding would not be sufficient: "There will not be enough revenue to meet all demands, and the Council will have to choose to support what appear to it to be the activities which are likely to do most to promote its objects. I doubt it everyone will agree with any of its choices or that anyone will agree with all of its choices" (Claxton 13). ${ }^{20}$

\footnotetext{
${ }^{20}$ Gregory Klages notes that the insufficient revenue from the endowment fund became increasingly problematic for the Council: "By 1963, the inadequacy of the Council's endowment to meet demand for its sectoral clients had become a pressing concern. Finding means to address an exponentially growing constituency, and to compete with a parallel provincial funding body, would constitute two of the Council's core struggles through the "long sixties"” (167).
} 
Composed of twenty-one non-specialists, entrusted with two million dollars per annum, which was already acknowledged as insufficient, the Council had to determine how to distribute the funds fairly. This required establishing some parameters that were not laid out in the Canada Council Act. This delineation of the Council's role began at the opening proceedings, ${ }^{21}$ where Claxton noted:

As a general rule I do not suppose that the Council will itself commission directly the production of artistic works. The Canada Council should not be another art factory to compete with or cut across existing activities; it should be a powerhouse to generate interest. (14)

In other words, the Council saw itself as being able to help authors and artists who had already managed to establish themselves without the help of the Council. Writing over two decades later, George Woodcock argues that the Council successfully stood by this mandate to promote art instead of creating it. He notes:

the myth that the Canada Council in itself inspired the artistic flowering of the past quarter of a century or so is untenable. Indeed, the council itself has rarely attempted or claimed to play an initiatory role. It has held pretty consistently that private effort must get an institution off the ground, whether it is a theatre or an

\footnotetext{
${ }^{21}$ At the opening proceedings, Claxton addressed the practical aims and limitations of the newly established Canada Coucil. Georges-Henri Lévesque, Vice-Chairman of the Canada Council, on the other hand, offered an explanation for why the arts need government patronage. Lévesque's explanation began by suggesting that Canadian artists offer an important national resource, before concluding that the Council must support art for art's sake:

The artists and the writers, these 'enfants terribles chéris de Dieu,' rank among the fairest representatives of the cultural heritage of a community and it is their works which best embody the true characteristics of a people. These works are part of the most precious assets of a nation. ... And yet, more often than otherwise, the artists suffer from poverty. Even in this prosperous country of ours, many who are extremely gifted live a life of insecurity and even of privation. Possessed of creative powers, they must nevertheless devote most of their time and energies to a struggle for their daily bread ... We too often forget that the artists and the writers also create wealth, but a kind of wealth often underestimated by an unconscious and sometimes unavowed materialism. (19-20)
} 
art gallery, a symphony, a literary magazine or a publishing firm. ... the council's policy has generally been to foster rather than initiate. (Strange 65)

Woodcock supports this method, echoing Claxton in noting "the council was not established to attempt the impossible task of creating art" (65). As Woodcock argues, the success of this system was that it allowed the Canada Council to come in after "the first stage in the natural selection of survivors has taken place" (65). In other words, art had to prove its worth, by showing it could survive on its own, at least for a little while.

Although writing was the area of the arts that received the least amount of funding, Canadian writers did receive some funding from the Canada Council. Writers mainly received funding through one of two ways. The more common method was through scholarships and fellowships, although the Council also gave out grants to specific projects, which occasionally benefited Canadian writers. In its first year, for example, the Council awarded E. J. Pratt a grant of $\$ 1,000$ for "Recognition on [his] $75^{\text {th }}$ birthday" (First Annual 59). Grants, however, were more commonly given for larger projects, such as C. F. Klinck's editorship of the Literary History of Canada, which received $\$ 3,600$.

Funding provided directly to writers was more commonly done through fellowships and scholarships. "Senior" fellowship amounted to about $\$ 4,000-4,500$ for one year, plus travel allowances, with the award being slightly higher for married winners. Examples of writers who received the senior fellowship in the first five years include: Hugh Garner, Ralph Gustafason, Irving Layton, Louis Dudek, Anne Hébert, Yves Théiault, and Miriam Waddington. The "junior" fellowships amounted to $\$ 2,000$ for one year, plus travel allowances. Examples of writers who received the junior 
scholarship in the first five years include: Leonard Cohen, Mordecai Richler, and Alfred Purdy. ${ }^{22}$

The Canada Council also occasionally provided funding for more experimental endeavours. In 1959, for example, the Council provided funding to support the Contact Poetry Readings in Toronto. In justifying its support for this project, the Council notes: "There should be nothing unusual in the reading of poetry aloud. Indeed in its origins it was most likely intended to be sung or recited. But readings of poetry have not been common in Canada, and therefore the assistance which the Council has recently given for this purpose was something of an experiment." The Council explains that

The Contact Poetry Readings was organized in Toronto by Raymond Souster, Kenneth McRobbie and Avrom Isaacs. The readings first began in 1957 and are held in what is now the Isaacs Gallery on Bay Street. Their purpose is not only to give pleasure to the audience, but to bring Canadian poets into direct contact with some of their readers who in turn can discuss their work and question them about it. (Third Annual 26)

The Council assisted "this experiment" by providing grants of $\$ 25$ to each of the eight poets $^{23}$ for a reading fee and for travel and accommodation costs. The Council

\footnotetext{
${ }^{22}$ Although Canadian writers were aided through the Council's scholarships, some Canadian authors felt that the Council favoured university professors over other writers. William Arthur Deacon, for example, made this complaint:

Canada Council's main object was and is to finance universities; and its money goesthat is the cash grants to persons-overwhelmingly to universities teachers. There are about 250 substantial cash gifts a year to B.A.'s who want M.A.'s or M.A.'s who want Ph.D.'s etc. Against this we have 15 small grants a year to writers who need cash to finish a book. Of course if it is a professor who wants a year off to finish a book he can get as much as $\$ 6,000$.

As a writer, I'm pretty bitter about this whole set-up. It was suggested that I apply to finance the writing of a book but I refused because I suspect that the Council made this suggestion for the mere purpose of humiliating me by a refusal. A ballet company or touring company of actors can get anywhere from $\$ 20,000, \$ 50,000$ to $\$ 125,000$ a year. Writers who are not professor[s] - to hell with them; none of them are any good. (Deacon, Letter to [Unknown], "Strictly Confidential")
} 
determined that the experiment in supporting a poetry reading was a success, not only because it allowed the public and the writer to interact, but because it also "helped counter the sense of isolation which some of our poets feel" (Third Annual 26). ${ }^{24}$ This attempt by the Council to mitigate the isolation felt by Canadian authors stems from the Massey report, which concludes its section on Canadian literature by suggesting that "it is this isolation which prevents [the Canadian author from] making his full contribution" (Report 227). The Council, in agreement with the Report, quotes one of the poets at length to explain how these types of readings were essential:

it strengthened my sense of contact. And I think this is of vast importance, creatively. And it is certainly of special importance to a writer like myself, living in an isolated part of the country cut off from direct communication with other writers or even with people who are interested in poetry from the audience standpoint. Throughout my youth I had to fight the thought that I was, perhaps, the only person in the world who was interested in the least in poetry ... The brief visit to Toronto helped offset that isolation, and thus helped me creatively. (ellipsis in original, Third Annual 26-27)

The Council continued to make these small grants to support similar local gatherings of poets and readers. In the winter of 1962, for example, the Council awarded a grant of $\$ 600$ to enable Canadian poets to travel to Ottawa and read their work to the public in a

\footnotetext{
${ }^{23}$ The eight poets who received this assistance were: Ralph Gustafson, Leonard Cohen, Denise Levertov, Alfred Purdy, A. J. M. Smith, Alden Nowlan, Gilles Hénault and Michèle Lalonde.

24 The Contact Poetry Reading series shared its name with Raymond Souster's Contact Press (1952-67) and his Contact magazine (1952-54). In this naming, he was "collectively emphasiz[ing] his concern with building and maintaining the community of Canada's poets" (Anstee, "Poet" 75). This belief in the benefit of "contact" between poets is emphasized in the Reading Series' funding request to the Canada Council: "these readings will do much to offset the sheer geographical handicap for poets of being scattered in all parts of Canada, for too few of them have personal contact with other writers in other parts of the country" (Kenneth McRobbie qtd. in Anstee, "Setting"). For a lengthier discussion of the Canada Council's funding of poetry readings in Canada, see Anstee "Setting Widespread Precdent."
} 
coffee-house called Le Hibou. This grant, apparently, caused "a great deal of speculation generally in the press" because "interest was stimulated by the appearance of an audience for the poet, Irving Layton, so large that two readings had to be given in one night in the limited facilities available. It must be rare anywhere that a queue should form on a cold night for a reading of poetry and we salute the occasion with delight" (Fifth Annual 28).

In its second year, the Council looked into "the earnings from the work of different types of creative arts." And they discovered what Canadian authors had been lamenting for the last decade: "The general reader can hardly imagine just how hard it is to make a living by writing fiction" (Second Annual 28). After analyzing numbers from the publishing industry, the Council determined that Canadian fiction authors were, at best, precariously employed. The Council notes that "A good sale [of a book of fiction in Canada] might run as high as 2,500 copies on which the writer would receive $\$ 875.00$. A sale of 15,000 copies of a novel by a Canadian published in Canada would be a very large sale. Only perhaps half a dozen have reached that figure in recent times. Such a sale might produce for the author . . . a total of about \$6,560.00" (Second Annual 28). The situation for French authors was even worse. As such, the Council began providing a program of assistance for publishers. In the first few years of this program, the assistance predominantly went to aid French publishers, with the occasional grant to translate a French work into English. If English publishers were given aid for publishing English novels, it was often through block purchases, which were "distributed abroad by Canadian missions through the good offices of the Department of External affairs" (Third Annual 35). For example, in 1959-1960, the following titles were selected to receive such block purchases: Irvin Layton's A Red Carpet for the Sun, Sheila Watson's The Double 
Hook, Morley Callaghan's Morley Callaghan's Stories, and Hugh MacLennan's The Watch that Ends the Night.

The Canada Council spent the introduction of its third annual report justifying its existence, and describing its impact on Canadian society in its short tenure. The introduction notes that statistics about the Council's spending can only tell part of the story, and it will never be able to prove that every grant produced something of "value" in exchange. The introduction, continuing its defensive positioning, concludes by noting that "no doubt many local skirmishes will be lost. The essential is that in the end the battle should be won" (Third Annual 1-2). Although it is not clear from this introduction what exactly the "battle" being fought by the Council was, a comment later in the annual report suggests that the Council's battle was to continue the fight commenced by the Massey Report: combatting the belief of the Canadian public that art belongs to the realm of the elite. As the Council notes:

Although perhaps the man in the street still harbours a lingering native prejudice against "high brow culture," the success of such ventures as the Stratford Festival, the Théâtre du Nouveau Monde, the Canadian Opera Company and the National Ballet have done much to prove that the pleasures of the arts are by no means reserved for those holding degrees or diplomas. The arts are beginning to move out of the quadrangle and into the market place. (Third Annual 61) This conclusion is a little surprising, as the absence of a strong market for Canadian culture was the very reason why the Canada Council was established. And although the Council might have been hopeful that the influx of government funding into the arts might have acted as a catalyst for growth in the industry, the increasingly heavy demands 
placed on the Council by Canadian artists suggested that this did not occur. Woodcock supports the notion that the Council's funding of the arts failed to have a strong impact on the martketplace, noting that in the early $1980 \mathrm{~s}$, in spite of [the] increase in both creative and public interest, the artists of Canada, with a few fortunate exceptions, were hardly better off as individuals than their less numerous predecessors had been when the Canada Council was established. It did not matter greatly what branch of arts one chose-writers or visual artists, actors or musicians - their average income was round about the accepted Canadian poverty line, and their mean income was generally below it, which meant that when one had counted out the tiny minority of big earners, artists as a class were the poorest people in the country except for old age pensioners and native people living on reservations. (Strange 8)

Despite the continued poverty-level income faced by the average Canadian artist, Woodcock argues that the Council did have an impact on increasing the output of Canadian art:

Obviously we cannot confer on the Canada Council the rank of muse, for it was a complex of influences far less tangible than the granting of money, or even the provision of moral encouragement, that inspired the Canadian artistic flowering of the past generation. We can perhaps best regard it as a midwife, helping in the successful birth of a lean and hungry child — a child susceptible to the infant ailments of a young culture. (Strange 71)

The Canada Council then aided Canadian art by protecting and shielding it from the harsh realities of the marketplace. In commenting on the economics of writing in Canada 
during the twentieth century, Frank Davey agrees, noting that "The trajectory, over the course of the twentieth century, was clearly toward greater economic stability for Canada's writers" (113). This stability, Davey notes, comes from government support, which "underscore[s] a belief that Canada's cultural industries are too important—and too fragile - to be left to the whims of the global marketplace" (113). Despite this government intervention, even after the Canada Council adopted more programs to support authors in the late 1960s, Canadian authors still struggled to earn a living wage. As Davey notes, in 1978 (the first year with hard figures) "the median income for all members of the Canadian labour force was $\$ 11,400$ " (104). By comparison, authors reported an average income "from writing of $\$ 6,761$ with a median of $\$ 2,500$ " (104).

Shortly after the Canada Council was formed, Watson Kirkconnell, President of the C.A.A., submitted a brief to the Council laying out the association's funding requests. Much of the brief reiterates the C.A.A.'s wishes from earlier briefs to the Turgeon Committee and the Massey Commission. First, the C.A.A. asked for the Council to provide cash prizes for the GG awards, along with covering the administrative costs of the Awards Board. Second, it asked for fellowships or scholarships for junior and senior writers, as well as aid for publication of works, to "rescue from oblivion works of profound literary merit" (qtd. in Kirckonnell, "Presidential" 10). Finally, the C.A.A. notes that the Massey Report stated that special consideration should be given to "the strengthening, by money grants and in other ways, of certain of the Canadian voluntary organizations on whose active well-being the work of the Council will in a large measure depend." As such, the C.A.A. suggested that "the Canadian Authors Association is one of these voluntary organizations" worthy of financial support. The brief notes: 
For thirty-six years, we have borne the burden and the heat of the day and have struggled with the slenderest means and heroically voluntary labour on behalf of authorship in this country. ... Again and again our deficits have threatened to swallow us up and only sacrificial giving has bridged this muskeg. We therefore submit that ours is one of those voluntary national organizations envisaged by the Massey Commissioners for which a substantial annual grant of perhaps $\$ 5,000$ would assure a proper headquarters, proper secretarial and clerical help, and the survival of our publications. (qtd. in Kirckonnell, "Presidential" 10)

There is no indication that the Canada Council introduced any funding as a direct result of this brief by the C.A.A. The Council did start offering cash prizes for the Governor General's Literary Awards, but it also took control of the awards out of the C.A.A.'s hands, as discussed in the last chapter. The Council did offer scholarships, as suggested by the C.A.A., but these had been part of the Council's plan before this brief was received. In essence, the Council appears to have, more or less, ignored the C.A.A. The Council did not grant its request for financial support of the C.A.A. itself. This was most likely because the Council had decided early on that one of its main principles would not be to support voluntary organizations that were financed by membership fees.

\section{Conclusion}

Paul Litt argues that government support for the book can be viewed in three phases. It begins with an early phase, prior to the end of WWII, in which government policies "indirectly affected the book"; it continues with a middle phase (discussed in this 
chapter) in which the government "developed new policies with cultural objectives but paid little attention to the book"; and ended with the rise of cultural industries policies, which "explicitly targeted book production" (Litt, "The State" 34-5). For a large amount of scholarship focusing on the development of government patronage of the arts in Canada, the rise of the welfare state, and the eventual shift towards the cultural industries as an essential component of Canada's economy, Litt's second phase marks an important beginning. For this project, however, governmental cultural intervention, and the establishment of the Canada Council, marks an important end. The possibility of a statefunded collective of professional authors was replaced with cultural policies that aimed to exclusively fund "high culture" and which "paid little attention to the book." This moment marks the end of the possibility of the "union of the ink-pot" that the creation of the Canadian Authors Association had hoped for.

Litt argues that the "absence of the book from government cultural policy in this period [the $50 \mathrm{~s}$ and early $60 \mathrm{~s}$ ] is understandable in the context of the defensive response to the rise of continental mass culture" ("The State" 36-7). It is understandable, Litt continues, because the book "predated the mass media that threatened high culture" and "was traditionally the privileged medium which stored the educated classes' cultural capital. Ironically, the book was disregarded because it was highly regarded" (37). This argument is somewhat reductive of the complex discussions that surrounded the book in this period, which were deeply shaped by competing views of literary authorship. Although the book was not seen to be as threatening to high culture as American television and movies were, some members of the literary field were concerned that if books were to be granted funding, it had to be for the right books by the right authors. 
During the rise of government patronage, this idea was most clearly articled by the C.W.C., a group of authors who came together because of a shared disagreement with the priorities of the C.A.A. The C.W.C., and like-minded critics of mass media, wanted to fund books that would edify the reading public - i.e. highbrow literature - and had disdain for books that simply sought to entertain. This view, and the larger fear of the corrupting influence of other mass media, became solidified in government policies, and the funding of the Canada Council. As Litt notes, "While the total dollar figure [the Canada Council] directed toward literary interests rose each year, it remained miniscule compared to the funding of high-overhead ballet companies and symphonies" ("The State" 40).

Studies that aim to understand the book in relation to government funding and cultural policies often discuss the book as a finished product, in relation to other media. They rarely, however, focus on the labourers - authors, editors, publishers-behind the book. This chapter, and this project as a whole, attempts to understand these large shifts in the way books and literature were understood in Canada by focusing on these labourers, by focusing on authors themselves. For the most part, the views endorsed by the C.W.C. during the Massey Commission - that government support should be reserved for authors of highbrow literature - were the views predominantly endorsed in the early government funding of the arts. As a result, literature that satisfied this view was funded, published, taught, and thus canonized. ${ }^{25}$ This narrative, however, has thus far ignored the complex debates that took place between the C.W.C. and those that opposed its views on

\footnotetext{
${ }^{25}$ Although the government's decision to fund the highbrow literature makes logical sense, in that it resulted in providing support for the literature that tended to sell poorly, it ignores the fact that very little literature sold well in Canada. The C.A.A.'s appeal for equal consideration of all authors is an attempt to acknowledge that very little literature was actually produced in Canada, regardless of the genre.
} 
literature, such as the Canadian Authors Association; it ignores the fact that the C.W.C. represented forty-two authors, while the C.A.A. represented over one-thousand authors; it also largely ignores the fact that books were a commodity that produced or supported the very livelihood of many Canadian writers.

This chapter draws out the distinctions between these two competing views on authorship within the literary field, pointing both to where they agreed and disagreed. Importantly, this chapter draws parallels to the previous two chapters, to show that these competing views did not arise in the post-war era. Instead, the C.A.A., in lobbying for support of all authors, as labourers, regardless of their skill, had been surprisingly consistent in its priorities since its establishment in 1921. The debate with its critics, in their various forms, also remains largely unchanged from the 1920s. The true change concerns the modernist critics' positioning in the cultural milieu. No longer are they the poet sitting "Far in the corner ... The very picture of disconsolation" (Scott 39). Instead, they managed to persuade government funding bodies to support their view of authorship. 


\section{Conclusion}

An important transition in Canadian authorship happened around 1960. It was not the result of a single event, but a gradual shift that saw the debates around authorship of the previous four decades coalesce into a more or less coherent understanding of Canadian authorship. Most of the Canadian Authors Association's major initiatives had ended or were about to end: Book Week ended in 1957, the Canada Council took control of the GG awards in 1959, and the Canadian Poetry Magazine was merged with the Canadian Author and Bookman in 1963. The establishment of the Canada Council ushered in an era of government support of the arts that continued to grow in the following decades. Although the C.A.A.'s membership remained steady well into the 1970 s, with the association still in existence today, its impact on the development of Canadian authorship languished dramatically after 1960 . The C.A.A.'s loss of cultural power coincided with early literary histories, which downplayed the C.A.A.'s role in the development of Canadian authorship. This transition and loss of cultural power by the C.A.A. was the result of a number of converging factors: prominent members of the C.A.A. retired or passed away; the stereotypes of the C.A.A., particularly its association with amateurism, became more ingrained; and, perhaps most importantly, it became identified as a group of "artisans," in contrast to the newly founded Writers' Union of Canada and its "professional" membership. 


\section{The C.A.A. and Its "Sunday Writers"}

By the late 1960s, the public at large appears to have accepted the stereotypes of the C.A.A. This can clearly be seen in the fallout of an event held by the C.A.A. in 1967. The association held its annual convention in Montreal on the site of Expo '67, called it the "Universal Writers Congress," and invited authors from around the world to the four-day event. The C.A.A. did not receive financial assistance, so despite its ambitious goals, only "about ten" foreign authors came from Australia, Japan, Yugoslavia, France, and Russia (Harrington 286). At the event, the C.A.A. bestowed the title of "writer of the Century" on Pierre Berton. ${ }^{1}$ The national press thoroughly covered the event - the Canadian Author and Bookman noted that the coverage was "a record for reportorial and critical attention" ("Editorial” 3) — and the coverage was almost unanimously disdainful. What is remarkable about the coverage, however, is the blatant scorn shown towards the C.A.A. and its members. In particular, critics of the event spent much more time attacking the age, sex, and professional status of the C.A.A.'s members then they did critiquing the event itself. For example, writing in the Toronto Daily Star, Robert Fulford stated "The C.A.A. is a collection of prairie poets, church magazine writers, unpublished novelists and geriatric cases" (qtd. in "Editorial" 3). A more thoroughly scathing critique of the event appeared in the Globe and Mail, where William French ${ }^{2}$ argued:

\footnotetext{
${ }^{1}$ This decision was critiqued. For example, Douglas G. Jones argued that "The affair reveals the essential bias of the C.A.A., and that is towards the popular. It tends to scorn and perhaps fear what is not popular. It has little truck with the avant garde or with the truly excellent" ("What is Wrong" 15). In this critique, Jones points to this example of the C.A.A. choosing the middlebrow over the "avant garde," and as such, Jones connects this with a rejection of "good" authors by the C.A.A. This affair mirrors closely the literal crowning of Bliss Carman as Canada's Poet Laureate four decades earlier.

${ }^{2}$ William French replaced William Arthur Deacon as literary editor for the Globe and Mail upon Deacon's retirement in 1960. French's articles and reviews proved to be as influential as Deacon's were before him.
} 
Professional writers in attendance were hopelessly outnumbered by members of the Canadian Authors Association.... The blame [for the poor quality of the event] rests all with the Canadian Authors Association, that resolutely square and increasingly moribund organization ...

If CAA delegates to the convention are representative, then the average Canadian author is a woman in her late sixties with nice grey hair who attends church twice on Sundays and writes for the Sunday school paper....

The danger of rigor mortis and the absence of younger writers at the convention was not lost on delegates. ("Writers' Convention" 24)

In this critique, French continues to support many of the stereotypes of the association made famous by F. R. Scott—-that the association is predominantly populated by amateur, aging women writers.

A year later, the C.A.A. sent inquiries to Canadian writers asking them "What is Wrong with the C.A.A.?" and several responses were published in the Canadian Author and Bookman. All of the responses show how widespread the stereotypes of the C.A.A. had become. For example, Brian Moore explained that he had never joined the C.A.A. because "I was told (again perhaps erroneously) that the membership was mainly little old ladies who had written the odd book review for the local Gazette" (qtd. in "What is Wrong" 15). Douglas G. Jones admits that "What I know of the CAA comes mostly from newspapers, conversations and occasional remarks" but he is confident that "Its image seems hardly to have changed since F. R. Scott wrote his satirical poem 'The Canadian Authors Meet', some forty years ago" (qtd. in "What is Wrong" 15). Although it is not clear when this shift in the perception of the C.A.A. became so widely accepted, it was 
well solidified by the late 1960 s, and has influenced the legacy of the C.A.A. to the present day.

\section{Authorship and the Royal Commission on Book Publishing}

In 1970, two Canadian publishing houses-W. J. Gage and Ryerson Press-were sold to American interests. These two sales made manifest a growing fear in Canada, prominently articulated in the Massey Report, of the potential for Canadian culture to be consumed by America. Kevin Dowler argues that post World War Two, these fears forced government intervention in cultural policy, as "[Government] inaction risk[ed] the probability of a slide into barbarism. This barbarism could come in two forms: the possibility of anarchy ... or, the overwhelming of the Canadian state by American mass culture" (337). As a result of the sale of these publishing houses, and the very real threat of American subsidiary companies in the Canadian market, the Ontario government created a Royal Commission on Book Publishing in December 1970. Two months later, on 18 February 1971, Jack McClelland, president of McClelland and Stewart, Canada's largest Canadian-owned publishing house, announced that his company was for sale and that he would not rule out selling to a foreign company. Roy MacSkimming notes that this news resulted in a public outcry: "almost everyone knew about M\&S and its importance to Canadian literature. The news seemed symptomatic of a culture in danger of annihilation" (147). The newly established Commission felt compelled to respond, and issued an interim report in March 1971, in which it suggested that the Ontario government provide $M \& S$ with a ten-year loan of one million dollars to avoid the sale of 
the company, noting that the publishing house "represents an accumulated creative momentum in original Canadian publishing ... [whose program is] a national asset worthy of all reasonable public encouragement and support" (Rohmer et al. 287). Book publishing, as an industry, was directly identified as a "national asset" worthy of — and as the final report would state, in desperate need of-financial support. Ontario quickly adopted the recommendation and provided M\&S with the loan. McSkimming argues that this is the moment when book publishing in Canada was seen as a cultural industry:

At a time when almost no public support was available to publishers, the royal commission's proposal was unprecedented. . . Book publishing would no longer be regarded as a business like any other; it was a key cultural industry, producing what economists call "merit goods," things of intrinsic value to society that must not be abandoned to the mercies of the market. (149)

The fear for book publishing, in particular, was that the "mercies of the market" would result in American economic interests completely subsuming Canadian publishing — and by extension, Canadian writing.

The report of the commission, Canadian Publishers \& Canadian Publishing, continually emphasizes that it is not sufficient to only look at the economic aspects of publishing in Canada, as "the Canadian book publishing industry simply makes too small a contribution to the gross national product for economic considerations to earn it any priority over many other fields of enterprise" (Rohmer et al. 219). The Commissioners, however, were thoroughly convinced that despite the inability for the industry to be economically solvent in the open market, publishing must have funding priority over other industries in Canada because of the invaluable cultural role that it plays. 
Specifically, the commissioners saw this cultural role as: "nurture[ing] a firm sense of Canadian identity at home and to project the Canadian identity abroad" (16). The commission consistently emphasized the role that books play in creating and shaping a unique Canadian "identity." Critics of Canadian cultural policy note that government discourse around cultural policy following the Second World War "often frames its mandate in terms of the construction of a Canadian identity" (Dowler 330). This emphasis on shaping identity was a means of ensuring national security: "From the perspective of security, identity is simply one of the desired outcomes of state security aims. The governmental administration of culture should be seen as a set of 'tactics' ... to enhance security and ensure the continual reproduction of the Canadian state" (330; see also Pennee and Berland). Donna Pennee similarly argues that the Massey Report emphasized this role for culture, noting the report's "rhetoric of maturity urges investment in cultural policy as a means of securing a national culture worthy of 'her [Canada's] new international importance"' (197). Through government-supported institutions, such as the $\mathrm{CBC}$, the NFB, and the Canada Council, the government financially supports the manufacturing of culture to "inculcate in Canadian citizens a sense of culture that would be both civilizing and —as a consequence—distinct from that of the United States" (Dowler 338). In this view, the Royal Commission on Book Publishing, and its recommendations, is the logical extension of the government's cultural policies that began in the 1930s with the establishment of the CBC, and were reinforced after the Massey Commission. Following the 1970s, however, Dowler argues that cultural policy in Canada changes, and we see "an increasing convergence of industrial, economic and cultural policy" (341). Culture begins to transition into an 
essential part of the nation's economy. As such, Dowler argues "its former status as the locus of the construction of identity must be renegotiated" (342). The commissioner's report is one of the first government documents that directly identifies the importance of Canadian authors to the nation, to the economy, and to the continuation of a uniquely Canadian identity. Despite the fact that it relies heavily on the role of literature in producing identity connects it with earlier cultural policy in Canada, it did support the notion that books are commodities - even if they are not lucrative in the current moment, they could be at some point. As Paul Litt notes, the report "made it clear that the book was a product not just of literary genius but of a healthy publishing industry as well” ("The State" 42). As such, the report is nodding towards a cultural-industry strategy that moves beyond simply creating a unique identity that Dowler sees occurring in the late 1970s.

While the Massey Commission, like the report on Canadian publishing, ${ }^{3}$ made a strong appeal for the importance of cultural products to the formation of a unique Canadian identity, its attention was predominantly on media other than books, and as a result, had few recommendations that directly addressed Canadian authors. In contrast, the Report of the Commission on Book Publishing consistently emphasizes the importance of the author: "Beyond question ... it is the climate for authorship that must concern this Commission in the end;" "our first regard should be for Canadian authors;" "If the public has an interest in the welfare of Canadian book publishing . . . its first concern must be for Canadian authors" (Rohmer et al. 10, 16, 45). This concern for

\footnotetext{
${ }^{3}$ It is important to note that the Massey Report was addressing federal cultural policy, while the Report of the Commission on Book Publishing was addressing Ontario cultural policy. Despite this difference, since the vast majority of Canadian publishing houses are located in Ontario, the province's cultural policy on book publishing has an impact on the national literary field.
} 
Canadian authors as the most important aspect of the publishing industry derives from the cultural role that the commissioners believed the book industry played in Canada:

If books are to define Canadian identity in the future and embed it in the national consciousness, Canadian authors must write them. If these books are to command the love and interest of Canadians and the respect of readers elsewhere, only the literary competence of their authors will bring this about. We shall serve ourselves poorly if we do not create a climate for Canadian authorship in the future that will stimulate the best talent and hold it in this country. Promising authors are going to have to be given the incentive and the opportunity to write.

In this view, publishing in Canada (specifically Ontario) —along with provincial government support and protection of Canadian publishing - is worthwhile because of its ability to publish Canadian authors, who in turn, "define Canadian identity" for the reading public; or, as Dowler argues, "a culture must be constructed to meet the political objective of policing the actual borders" (339). In this passage, and throughout the report, the commissioners often echo much of the rhetoric used by the C.A.A. to defend its patriotic appeal to read Canadian books during Book Week. The report, however, is careful to not attract the same criticism that the C.A.A. did during Book Week, for "blindly" supporting all Canadian literature. The Report insists that "Canadian works ... must measure up to foreign books available in this country in literary quality, physical format, interest, and imagination. If they do not, they will not find readers" (49). This perspective appears in sharp contrast to the debates faced by the C.A.A. during the 1920 s, where Stead insisted that Canadian books could not be expected to "run" before they 
could "walk." Due to the political climate in which the report was written, it insists that its recommendation for government support of publishing is not to be confused with political indoctrination, noting "No one wishes to convert our school children into little Nazis" (220). ${ }^{4}$ The report concludes by reemphasizing the importance of this cultural industry, noting that because publishing in Canada is economically inadvisable, "Government assistance, in whatever form, can be justified only to the extent that furnishing it will enrich and protect the cultural life of the people in Ontario and Canada" (219). Litt notes that the recommendations of the report "were destined, like those of most official inquiries, to be ignored by the government that had asked for them" ("The State" 42). But, as Litt points out, the federal government did establish the Book Publishing Development Program in 1979, creating the first block grants to Canadianowned publishers, which began at $\$ 5.7$ million in 1979-80.

The commissioner's report supports many of the claims about authorship and the literary marketplace that the C.A.A. promoted during Book Week. For example, the idea that books are commodities was now widely accepted. As well, the report argues that the various agents of the literary field need to support each other rather than "compete" (10), echoing the argument the C.A.A. made in the 1920s when it was accused of “indiscriminately mingling” with publishers and booksellers. This report, however, did not support the C.A.A.'s view that all Canadian authors were worthy of support. Instead, it followed the Massey Report's lead in arguing for the financial support of "professional" authors. In tracing the success of Canadian modernists in influencing state

\footnotetext{
4 Dowler notes that when the Massey Report was written, "there was a great deal of sensitivity about government roles in the production of culture, specifically fears of totalitarianism that recent experience had taught was the result of central government control" (334; see also Litt, Muses 103-05). This fear was still evidentially a real concern in the early 1970 s.
} 
support of high culture, Jody Berland notes that "From the 1950s to the 1980s only 'autonomous' art was understood to be useful and deserving of government support' (21). This accepted hierarchy, which considers only some authors as worthy of support, can be seen in the background paper on the state of Canadian authorship written by George Woodcock for the Royal Commission. While in 1951, the Massey Report unequivocally stated that Canadian literature, as a field, did not yet exist, by 1972, Woodcock could assert that "most critics in Canada and a growing number of critics abroad ... [accept] a distinctive Canadian tradition has in fact emerged, and is producing a literature that is growing" ("On the Resources" 66). While a Canadian literature, according to Woodcock, had finally emerged, Canada still had "very few men of letters who live entirely by their writing" ("On the Resources" 62). Despite this, Woodcock claims that all Canadian books of "real merit" were able to get published in Canada"With rare exceptions, I believe that during the 1960s and 1970s all of them have had their chance, and sooner more often than later" ("On the Resources"64). Coinciding with this increase in the publishing of Canadian books, Woodcock notes that "Far fewer books whose badness comes from conventionality and timidity now appear," which he directly connects to the fact that "The old guard of the Canadian Authors Association has been decimated by death, routed by age” (“On the Resources” 62). Thus, in Woodcock's view, the literal dying off of the C.A.A. allowed for "classic writers" _ E E. J. Pratt, F. R. Scott, Morley Callaghan, Sinclair Ross, Hugh MacLennan, A. J. M. Smith-to emerge. Woodcock notes that all of these authors belong to the modernist movement—- "the movement to which almost all of our significant writing in some way belongs" (70). In

\footnotetext{
${ }^{5}$ As Woodcock notes, "By classic writers in this context I mean, of course, the first generation of important writers who can be considered completely Canadian in outlook" ("On the Resources" 65).
} 
Woodcock's account of the state of authorship at the beginning of 1970, it is clear that the view of authorship put forward by modernist writers during the Massey Commission had become widely accepted. The modernists had become the "classic writers," whose work rarely fails to get published, resulting in a far greater number of books "committed to the art of fiction and a far less proportion by bromide hacks" (79).

\section{The Writers' Union of Canada}

This increase in the production of Canadian literature coincided with an attempt by authors to craft a narrative of the history of Canadian authorship, with a clearly demarcated line between "before" and "after" 1960. Margaret Atwood, for example, argues that "Since the 1960s the public's image of the Canadian writer has changed... from defective freak to acceptable member of society." Similarly, Woodcock argues "I met nobody in 1949 who lived by writing. . . . We were a country of Sunday writers. Real literary professionalism hardly existed. Today [in 1979] the situation is vastly different. . .. As many good writers have emerged in Canada during the past 20 years as in the whole previous history of our literature" ("Mermaid Inn" 6). Both of these characterizations of the development of authorship in Canada correspond to what has become the accepted narrative in contemporary literary histories. Both of these characterizations, however, were made to explain the importance of the Writers' Union of Canada, and in doing so, dismiss and downplay the role played by the C.A.A. in the first half of the twentieth century, as well as the rich and diverse array of literary writing and writers that came prior to 1960 . 
The Writers' Union of Canada was officially formed in Ottawa on 3 November, 1973. The catalyst for its creation was the Royal Commission on Book Publishing. As Christopher Moore explains in his history of the Union: "Who speaks for Canadian writers? In 1971 the answer seemed clear: no one. That year an Ontario royal commission held public hearings on the state of the book trade — and not a single writer or writers' organization was asked to testify." ${ }^{36}$ As a result of this perceived lack of lobbying power, Farley Mowat organized writers-including June Callwood, Graeme Gibson, Margaret Atwood, Ian Adams, and Fred Bodsworth — to raise their shared concerns before the Commission (Moore). The Report of the commission does mention both the Canadian Authors Association, and the group of authors Mowat organized. The Report notes: the only organization that even pretends to coordinate the interests of book authors in this country is the Canadian Authors' Association. . . Unfortunately, a number of the most successful Canadian authors are not members of the Canadian Authors' Association. Many of the latter seem to eschew any kind of professional organization, and some of them take the position that the existing national association serves social rather than purely professional ends. Eleven such authors appeared before this Commission at its final regular public hearing to announce their intention of forming a new author's union. However, as the different members of the group voiced their opinions, one by one, the policies and attitudes of this new body turned out to be considerably less than unanimous. Indeed, disagreement among them became so outspoken that two of their number expressed their protests by withdrawing even before the group submission had

\footnotetext{
${ }^{6}$ I have been unable to verify Moore's claim that "not a single writer or writers' organization was asked to testify" before the Commission, but the C.A.A. did at least submit a written brief.
} 
been completed, and before the Commission had fully entered the discussion.

There is a moral in this, surely. (Rohmer et al. 48-49)

After speaking before the Commission, a group of these authors retired "to a pub to discuss the events of the hearing over hotdogs and beer. Some of them had never met before. They decided that they must meet more often, and the nucleus of The Writers' Union was formed" (Moore). Further meetings followed, funded by both the Ontario Arts Council and the Canada Council, including a meeting in June 1973 in Toronto, where approximately eighty of the invited one-hundred and fifty authors met to confer about "establishing a professional association for published book writers" (Hamilton xii). The inaugural meeting of the Writers' Union of Canada took place a year later, in Ottawa, on 3 November 1973, where F. R. Scott acted as chair, and Marian Engel was elected as the organization's first chairwoman. Atwood notes "The union initially comprised a small number of authors who felt that writers must work as a unified group if they were to gain any measure of control over the economic conditions influencing them."

At their first official meeting, the members of the Writers' Union made it clear that they viewed themselves as "a militant nationalist group, calling for the Canadianization of all aspects of book publishing and distribution," and they gave notice that "the union will be militant, activist and political" (French, "Writers Take" 14). The union was ambitious, and did manage to strengthen the position of Canadian authors in a number of ways. In its first years, the union focused on establishing standardization of publishing contracts, and lobbied for the creation of a public lending right, which would pay author royalties for books borrowed from libraries. Some of its more ambitious plans included lobbying for "government action to require that all publishing houses in Canada 
be Canadian-owned. There was talk, too, of agitating for minimum Canadian content in bookstores" (French "Writers Take" 14). The Union also took its stated goal of militant activism seriously. For example, in 1975, approximately 50 writers from the Union “marched outside a Coles Book Store in Ottawa, protesting the chain's practice of selling American editions of their books at cut-rate prices. Canadian writers earn no royalties on books sold in this manner; Canadian publishers earn no profit" ("Copyright, More or Less" 6).

The Union was strict in its policy around membership. It was, unquestionably, to be a union for professional prose writers only. ${ }^{7}$ As such, applicants had to be Canadian citizens (or landed immigrants) with a trade book published by a commercial publisher or university press within the previous seven years, or still have a book in print (French "Writers Take" 14). The Union considered establishing a membership committee with the power to consider the professional merit of each application, but after protest, this condition was not adopted. ${ }^{8}$ Further, as a professional organization, the Union established criteria by which members could be penalized for improper behavior. As well, if a

\footnotetext{
${ }^{7}$ Atwood notes that the Union was restricted to prose writers because the League of Canadian Poets, founded in 1966, already existed. Some writers were members of both organizations.

${ }^{8}$ William French notes that this was the most controversial clause in the creation of the Unions constitution. Opposition to the clause was led by Pierre Berton, "who denounced it as elitist and snobbish and said he'd be damned if he'd give the five committee members power to judge his professional merit. He favored wide-open membership, drawing the line only at authors of vanity press books and selfpublished books." In this line of argument we see parallels with critiques of the C.A.A.'s membership process. It is worth nothing that even in Berton's rejection of the clause as "elitist," he is willing to exclude self-published authors.

Proponents of the clause argued that it would help insure that amateurs- "one-book academics and authors of histories of Renfrew County, for example"-were not eligible to be part of wh to be a "professional" organization ("Writers Take" 14).
} 
publisher was deemed "unfair" by the Union, members were prohibited from continuing to deal with that publisher without special permission. ${ }^{9}$

The Writers' Union and the C.A.A. shared a number of commonalities. Both were groups of Canadian authors who banded together to improve the conditions of authorship in Canada. ${ }^{10}$ Both groups lobbied the government around copyright, and promoted the importance of Canadian authors to the cultural life of the nation. Many of the motivations behind the C.A.A.'s Canadian Book Week event—particularly the desire for authors to be directly involved in the promotion of their work-were similar to activities of the Writers' Union. For example, the Union was "particularly annoyed with the way publishers promote their books. It set up a special committee-Margaret Laurence, Pierre Berton, Alice Munro and James Bacque - to advise publishers how to reach a wider audience through more astute promotion" (French, "Writers' Union Looking" 15). ${ }^{11}$ Some of the Union members, such as F. R. Scott, were now supporting initiatives - such as the Union's explicit focus on the "Canadianization" of the literary marketplace - that they had criticized the C.A.A. for doing decades earlier.

Despite the shared goals of the two organizations, the Union insisted on separating itself from the C.A.A. This was done in two ways. First in crafting a narrative

\footnotetext{
${ }^{9}$ This rule was employed at least once. In 1977, "After hearing complaints from two members about their dealings with Kakabeka, a small Toronto publishing house" the union decided to blacklist it until the grievances were settled (French, "Writers' Union Robust" 13).

${ }^{10}$ From the Writers' Union constitution:

The purpose of The Writers' Union of Canada is to unite Canadian writers for the advancement of their common interests. These interests include: the fostering of writing in Canada; relations with publishers; exchanged of information among members; safeguarding the freedom to write and publish; and the advancement of good relations with other writers and their organizations in Canada and all parts of the world. (Hamilton xi)

${ }^{11}$ One difference between the C.A.A. and the Writers' Union was their perception of publishers. While the C.A.A. attempted to work with publishers during Book Week, and advocated for solidarity among agents in the literary field, the Union felt that "publishers [were] inefficient and incompetent and treat[ed] authors like children" (French, "Writers' Union Looking" 15).
} 
that Canadian literature changed after 1960, as previously discussed. And second, by shaping how the C.A.A. was viewed, particularly by emphasizing its connection with amateurs to counter the Union's focus on "professionals.” For example, in his history of the Union, Christopher Moore notes that the Union focused on "professional concerns, not ... teaching [authors] to write." He continues:

The Canadian Authors' Association, founded in 1921, already served "craft" interests through a national network of branches in which aspiring and established writers could hone its skills and seek markets. The Writers' Union was to be a union for published writers.

In this phrasing, the C.A.A. becomes an organization for authors who are still learning the craft, while the Union is reserved for authors who have been published, and have thus become "professionals." The implication is that the concerns of these two organizations are necessarily different. This depiction of the C.A.A. is echoed in George Woodcock's account of the Union, in which he notes that the old Canadian Authors' Association survives, but mainly as a memento of the days when authors were amateurs; the Writers' Union is an organization of professionals, and it makes clear the shift from the old days of the Sunday writer to the new days of those who can afford to make writing a full-time occupation. (“Mermaid Inn” 6)

In this account, the C.A.A. has served its purpose, and no longer fulfills a needed role. Similarly, Timothy Findley, a prominent member of the Union, in reviewing Lyn Harrington's history of the C.A.A. Syllables of Recorded Time, argues that: "Syllables of Recorded Time suffers from a plethora of what can only be called 'name-thudding.' But 
name-thudding is a disease that has plagued the CAA from the outset. It every member of the CAA were to buy a copy of this book, there can be no question its author would have a bestseller" (E15). In this comment, Findley invokes a stereotype that has plagued the C.A.A. since its inception: its reliance on amateur authors who are happy to be associated with the "literati," instead of striving to belong to it themselves. These attempts by members of the Union to shape the history and legacy of the C.A.A., alongside earlier satires of the C.A.A., such as F. R. Scott's poem, have had a lasting impact. As this dissertation has shown, however, these characterizations of the C.A.A. ignore the important contribution that the association played in the development of Canadian authorship during the first half of the twentieth century.

For its part, the C.A.A. had very little to say publicly about the Writers' Union. For the first few years after the Union's creation, the only direct reference to the Union in the C.A.A.'s official publication, Canadian Author and Bookman, is a response to a letter received from the Australian Society of Authors enquiring about the connection between the two organizations. The Australian Society asked: "Why [the Writers' Union was] considered necessary in view of the strength and experience of the Canadian Authors Association? Is the Union a breakaway group? Do they consider the Association too much of a literary society and insufficiently militant and nationalistic?" ("You Asked" 19). In response, Lyn Harrington explained that the Union was not a breakaway group, but that it was "a 'ginger' group of youngish authors." 12 She notes that the C.A.A. was "surprised at the generous funding by government to an organization before it was even

\footnotetext{
12 In labeling the Union as a "ginger group," Harrington is probably suggesting that the Union is a small group of authors trying to influence the direction of authors as a whole. She might, however, also be suggesting that they are specifically socialists, by connecting them with the Ginger Group, a 1920s faction of the Progressive and Labour parties that advocated for socialist causes.
} 
formed. ... To date, the Canada Council has found nothing [of the C.A.A.] to approve" and concludes by wishing "there had been some consultation, to avoid duplication of effort" ("You Asked" 19). It appears that both organizations wanted to be independent of each other, despite their shared goals. In her history of the C.A.A., Harrington only briefly mentions the creation of the Union, noting correctly that "the Writers' Union left out in the cold the non-professionals and writers in other genres" besides novels and nonfiction books (Syllables 297). She concludes, "Whether or not they realized it ... [they] benefitted from the spadework done by the Canadian Authors Association" (Syllables 297).

\section{Conclusion}

The early twentieth century saw the production of literature become modernized. The rise of cheaper paper, more efficient printing methods, and easier distribution along railroads all coalesced to produce a more commodified publishing industry in Canada, allowing mass-market fiction to flood the market. Heather Murray has referred to this moment, where modern commodification meets an increased output of middlebrow literature, as "middlebrow modernism" (177). And it was in this moment that the C.A.A. emerged. As

a result, when attempting to articulate its understanding of authorship, the association had to navigate the public's desire for the middlebrow alongside modernist writers' desire to maintain a more conservative definition of highbrow literature, which disavowed the market. 
The association's first decade was spent articulating two competing definitions of authorship. The first, articulated during its lobbying for a copyright law that protected the rights of Canadian authors, positioned the association against publishers and printers. In this articulation of authorship, the C.A.A. argued that authors had an inalienable right to the reproduction of their work that was more important than the geopolitical realities of the modern world. At the same time, however, the association was joining publishers in promoting Canadian literature, through Book Week. In this second articulation of authorship, the C.A.A. argued that in order to survive financially, authors needed to adapt to the commodification of literature, and help to promote the products of their labour. These two conceptions of authorship were at odds with each other, but the C.A.A. eventually began to more fully embrace the second position—embracing the commodification of literature, and supporting literature that the reading public was actually consuming (i.e. middlebrow literature) — as it allowed for a wider range of writers to earn a living wage from their writing.

Despite the opinion of its critics, by the mid-1930s the C.A.A. had begun to acquire substantial cultural capital in the literary field. It had an average membership of over seven hundred members, which included some powerful and influential figures, like William Arthur Deacon. After gaining the support of Lord Tweedsmuir-himself the author of best-selling middlebrow fiction - the association had acquired the "monopoly of literary legitimacy" (Bourdieu, Field 42), allowing them to consecrate writers who satisfied the association's definition of authorship. This consecration was done through the Governor General's Literary Awards, which, for the most part, rewarded middlebrow writers. The goal of the award system was to select titles that would actually be read by 
the reading public, in the hopes of increasing the demand for more Canadian literature. In attempting to consecrate middlebrow writers, Deacon was also trying to discredit writers who did not satisfy the association's conception of authorship - namely, modernist writers of highbrow literature.

The end of the Second World War brought with it an increased awareness of the role of government support for culture. Eager to guarantee government support of writing in Canada, both the C.A.A. and modernist writers lobbied the government for patronage of the arts. While these two groups of writers shared many commonalities - they both acknowledged, for example, that it was difficult for Canadian writers to earn a living wage off of their writing - they strongly disagreed over who should qualify as an "author." The C.A.A. continued its support of all writers, including writers of lowbrow and middlebrow writing, while the modernists insisted on a more rigid definition, which would see support go to writers of highbrow fiction who disavowed the marketplace. Despite the literary legitimacy that the C.A.A. held for the previous two decades, government patronage of the arts fully supported the modernist writers' hierarchical conception of authorship. Government patronage of the arts eventually created a boom in publishing in Canada, which resulted in the "professional" authors of highbrow literature acquiring cultural capital, while the C.A.A. was labeled as a collective of "amateur" writers.

Although its role in the development of Canadian authorship is often glossed, or mocked, by the literary history of Canadian modernism, the C.A.A. played an important role in articulating and defining Canadian authorship. By focusing on this association, this dissertation refutes the narrative that Canadian authorship was the result of a 
vanguard of modernist writers standing collectively against an older generation of "amateur" writers. Instead, it insists on the importance of a history of authorship that includes dissenting conceptions, specifically those articulated by the C.A.A., which resisted the practice of creating hierarchies for authors based on gender, age, quality of work, chosen genre, or "professionalism." The development of authorship in the first half of the twentieth century was a site of debate and contestation. From 1921-1960, there was increasing pressure to define this key role in the national literary field. This pressure to define authorship can be seen: in the legal debates around copyright, which had ramifications for both the state-in becoming an independent signatory of the Berne convention - and for private industry; in the debates between authors themselves, as seen during Book Week, which sought to determine the proper relationship between literature and the marketplace; and in the rise of government patronage of the arts, which saw the state developing new ways to both fund and regulate culture. During these various debates over the role of authorship, the C.A.A. generally resisted hierarchies, and in doing so defended the middlebrow (and, by extension, women writers) and the author as a skilled labourer in the literary field, although the association was not always consistent in advocating these positions. This inconsistency, however, demonstrates how complicated it was during this period to have a single definition of authorship. Therefore, Canadian literary histories that only recall the modernist narrative of the rise of authorship lose a sense of this important contest, and the role played by the "union of the ink-pot." 


\section{Appendix I}

\section{Judges of the Governor General's Literary Awards from 1937-1959}

Note: Official lists of judges were published starting in 1943. These official listings often included occupation and city of residence. I have copied the information, when present, as it appeared in the Canadian Author and Bookman or the Globe and Mail.

The list of judges for the awards from 1937-1942, I've compiled from archival records. Although I believe them to be accurate, correspondence found in the archives suggest that sometimes the judges that were appointed failed to fulfill their role, and last minute replacements had to be found.

Judges were often identified simply by their last name and initials. Where possible, I have provided the judge's full name in square brackets.

\begin{tabular}{|l|}
\hline \multicolumn{1}{|c|}{ Judges in 1937 for books written during 1936} \\
\hline McLay, W. S. [Walter Scott Williams] \\
\hline Scott, Duncan Campbell \\
\hline \multicolumn{1}{c|}{ Non-Fiction } \\
\hline Wrong, George \\
\hline Wallace, W. S. [William Stewart] \\
\hline
\end{tabular}

\begin{tabular}{|l|}
\hline \multicolumn{1}{|c|}{ Judges in 1938 for books written during 1937} \\
\hline \multicolumn{1}{|c|}{ Fiction } \\
\hline Sandwell, B. K. [Bernard Keble] \\
\hline Rhodenizer, Dr. V. B. [Vernon Blair] \\
\hline Deacon, William Arthur \\
\hline \multicolumn{1}{|c|}{ Poetry } \\
\hline Roberts, Sir Charles G. D. \\
\hline Edgar, Dr. Pelham \\
\hline McPhail, Sir Andrew \\
\hline Brown, E. K. [Edward Killoran] \\
\hline \multicolumn{1}{|c|}{ General Literature } \\
\hline
\end{tabular}


Gibbon, J. Murray

Wallace, W. S. [William Stewart]

Brett, G. S. [George Sidney]

\begin{tabular}{|l|}
\hline \multicolumn{1}{|c|}{ Judges in 1939 for books written during 1938} \\
\hline Barnard, Leslie Gordon (chairman) \\
\hline Kennedy, Roderick S. \\
\hline Allison, Dr. W. T. [William Talbot] \\
\hline \multicolumn{1}{c|}{ Poetry } \\
\hline Edgar, Dr. Pelham \\
\hline Scott, Dr. Duncan Campbell \\
\hline Roberts, Sir Charles G. D. \\
\hline \multicolumn{1}{c|}{ General Literature } \\
\hline Deacon, W. A. (chairman) [William Arthur] \\
\hline Pratt, E. J. [Edwin John] \\
\hline Rhodenizer, Prof. V. B. [Vernon Blair] \\
\hline
\end{tabular}

Judges in 1940 for books written during 1939

\section{Fiction}

Deacon, William Arthur (chairman)

Pratt, Dr. E. J. [Edwin John]

Clay, Charles

\section{Poetry}

Edgar, Dr. Pelham (chairman)

Brown, E. K. [Edward Killoran]

Roberts, Sir Charles G. D.

General Literature

Barnard, Leslie Gordon (chairman)

Stewart, Dr. Herbert L.

Kennedy, Roderick S.

\begin{tabular}{|l|}
\hline \multicolumn{1}{|c|}{ Judges in 1941 for books written during 1940} \\
\hline \multicolumn{1}{|c|}{ Fiction } \\
\hline Barnard, Leslie Gordon \\
\hline Kennedy, Roderick S \\
\hline Morgan-Powell, S. [Samuel] \\
\hline \multicolumn{1}{c|}{ Poetry } \\
\hline Bourinot, Arthur S. \\
\hline Scott, Duncan Campbell \\
\hline General Literature \\
\hline
\end{tabular}




\begin{tabular}{|l|}
\hline Deacon, William Arthur \\
\hline Pratt, E. J. [Edwin John]] \\
\hline Clay, Charles \\
\hline
\end{tabular}

\begin{tabular}{|l|}
\hline \multicolumn{1}{|c|}{ Judges in 1942 for books written during 1941} \\
\hline \multicolumn{1}{|c|}{ Fiction } \\
\hline Stewart, Dr. H. L. (chairman) [Herbert] \\
\hline Martin, Prof. Burns \\
\hline Bird, Will R. \\
\hline \multicolumn{1}{|c|}{ General Literature } \\
\hline Scott, Duncan Campbell (chairman) \\
\hline Stephen, A. M. [Alexander Maitland] \\
\hline Dilworth, Ira \\
\hline \multicolumn{1}{|c|}{ Geacon, William Arthur (chairman) } \\
\hline Middleton, J. Edgar [Jesse] \\
\hline Sanderson, Charles R. \\
\hline
\end{tabular}

\begin{tabular}{|c|c|c|}
\hline \multicolumn{3}{|c|}{ Judges in 1943 for books written during 1942} \\
\hline \multicolumn{3}{|c|}{ Fiction } \\
\hline Sullivan, Alan & novelist and radio scripter & Toronto \\
\hline $\begin{array}{l}\text { Middleton, J. E. [Jesse } \\
\text { Edgar] }\end{array}$ & Literary Editor, Toronto Saturday Night & Toronto \\
\hline Endicott, Prof. Norman & Prof., Dept. of English, University College & Toronto \\
\hline \multicolumn{3}{|c|}{ Poetry } \\
\hline Grayson, Ethel Kirk & Novelist & Moose Jaw \\
\hline $\begin{array}{l}\text { Kirkwood, Mrs. M. M. } \\
\text { [Mossie May] }\end{array}$ & Dept. of English, St. Hilda's College & Toronto \\
\hline Duff, L. B. [Louis Blake] & Author & Welland, ON \\
\hline \multicolumn{3}{|c|}{ Creative Non-Fiction } \\
\hline $\begin{array}{l}\text { Sedgewick, Prof. G. G. } \\
\text { [Garnett Gladwin] }\end{array}$ & $\begin{array}{l}\text { Dept. of English, University of British } \\
\text { Columbia }\end{array}$ & Vancouver \\
\hline $\begin{array}{l}\text { Deacon, W. A. } \\
\text { [William Arthur] }\end{array}$ & Literary Editor, Globe \& Mail & Toronto \\
\hline $\begin{array}{l}\text { McLay, Prof. W. S. W. } \\
\text { [Walter Scott Williams] }\end{array}$ & $\begin{array}{l}\text { formerly Professor of English, McMaster } \\
\text { University }\end{array}$ & Hamilton \\
\hline \multicolumn{3}{|c|}{ Academic Non-Fiction } \\
\hline $\begin{array}{l}\text { Files, Prof. H. G. } \\
\text { [Harold Gershorn] }\end{array}$ & Dept. of English, McGill University & Montreal \\
\hline Morley, Rev. Frank S. & Stanley Presbyterian Church & Montreal \\
\hline $\begin{array}{l}\text { Latham, Prof. G. W. } \\
\text { [George] }\end{array}$ & formerly Prof. of English, McGill University & Montreal \\
\hline
\end{tabular}

Judges in 1944 for books written during 1943 


\begin{tabular}{|c|c|c|}
\hline \multicolumn{3}{|c|}{ Fiction } \\
\hline Edgar, Dr. Pelham & & \\
\hline Bourinot, Arthur S. & Barrister & Ottawa \\
\hline Hurlow, W. J. & literary editor of the Ottawa Citizen & Ottawa \\
\hline \multicolumn{3}{|c|}{ Poetry } \\
\hline $\begin{array}{l}\text { Sedgewick, G. G. } \\
\text { [Garnett Gladwin] }\end{array}$ & Prof, Univ. of British Columbira & Vancouver \\
\hline $\begin{array}{l}\text { Mackay, L. A. } \\
\text { [Louis Alexander] }\end{array}$ & Prof, Univ. of British Columbira & Vancouver \\
\hline Stevenson, Yvonne & Author & Vancouver \\
\hline \multicolumn{3}{|c|}{ Creative Non-Fiction } \\
\hline Sanderson, Charles R. & Chief Librarian of Toronto Public Libraries & Toronto \\
\hline Clay, Charles & National Secretary of CAA & \\
\hline Deacon, William Arthur & Literary Editor, Globe \& Mail & Toronto \\
\hline \multicolumn{3}{|c|}{ Academic Non-Fiction } \\
\hline Smith, Sidney & President, University of Manitoba & Winnipeg \\
\hline Phelps, Arthur L. & Prof, University of Manitoba & Winnipeg \\
\hline Owen, David & Prof, University of Manitoba & Winnipeg \\
\hline
\end{tabular}

*Note: The original judges in the Creative Non-Fiction category for 1944 were V.B. Rhodenizer (chairman), Dr. H.L. Stewart, and Juanita O'Connor. When these judges could not come to an agreement between two books, an arbitration committee was established, with the judges listed above: Sanderson, Deacon, Clay. Please see Chapter Two for a more comprehensive history of this event.

\begin{tabular}{|c|c|c|}
\hline \multicolumn{3}{|c|}{ Judges in 1945 for books written during 1944} \\
\hline \multicolumn{3}{|c|}{ Fiction } \\
\hline $\begin{array}{l}\text { Rutledge, J. L. } \\
\text { [Joseph Lister] }\end{array}$ & Publisher of Liberty & Toronto \\
\hline Jennings, Charles & CBC executive & Toronto \\
\hline Clay, Margaret & Chief Librarian & Victoria \\
\hline \multicolumn{3}{|c|}{ Poetry } \\
\hline $\begin{array}{l}\text { Pratt, E. J. } \\
\text { [Edwin John] }\end{array}$ & Poet & Toronto \\
\hline Kirkconnell, Prof. Watson & $\begin{array}{l}\text { Prof, McMaster University/Ed. Of Canadian } \\
\text { Poetry Magazine }\end{array}$ & Hamilton \\
\hline Calhoun, Alexander & chief librarian & Calgary \\
\hline \multicolumn{3}{|c|}{ Creative Non-Fiction } \\
\hline Duff, Louis Blake & Journalist & Welland, ON \\
\hline Barnard, Leslie Gordon & short-story writer & Montreal \\
\hline Godfrey, Eleanor & editor of Canadain Forum & Toronto \\
\hline \multicolumn{3}{|c|}{ Academic Non-Fiction } \\
\hline $\begin{array}{l}\text { MacKenzie, Dr. N. A. M. } \\
\text { [Norman Archibald } \\
\text { MacRae] }\end{array}$ & President, Univ. of British Columbia & Vancouver \\
\hline $\begin{array}{l}\text { Trueman, Dr. A. W. } \\
\text { [Albert William] }\end{array}$ & President, Univ. of Manitoba & Saint John \\
\hline
\end{tabular}




\begin{tabular}{|l|l|l|}
\hline Call, Frank Oliver & Krof. Emeritus, Univ. of Bishop's College & QC \\
\hline
\end{tabular}

\begin{tabular}{|c|c|c|}
\hline \multicolumn{3}{|c|}{ Judges in 1946 for books written during 1945} \\
\hline \multicolumn{3}{|c|}{ Fiction } \\
\hline $\begin{array}{l}\text { Rutledge, J. L. } \\
\text { [Joseph Lister] }\end{array}$ & Publisher of Liberty & Toronto \\
\hline Jennings, Charles & CBC executive & Toronto \\
\hline Clay, Margaret & Chief Librarian & Victoria \\
\hline \multicolumn{3}{|c|}{ Poetry } \\
\hline Kirkconnell, Prof. Watson & Prof, McMaster University & Hamilton \\
\hline Calhoun, Alexander & chief librarian & Calgary \\
\hline Cox, Leo & Vice-President of J. J. Gibbons Ltd & Montreal \\
\hline \multicolumn{3}{|c|}{ Creative Non-Fiction } \\
\hline Duff, Louis Blake & Journalist & Welland, ON \\
\hline Dilworth, Ira & western superintendent of $\mathrm{CBC}$ & Vancouver \\
\hline Phelps, Arthur L. & director of CBC's international service & Montreal \\
\hline \multicolumn{3}{|c|}{ Academic Non-Fiction } \\
\hline $\begin{array}{l}\text { MacKenzie, Dr. N. A. M. } \\
\text { [Norman Archibald } \\
\text { MacRae] }\end{array}$ & President, Univ. of British Columbia & Vancouver \\
\hline $\begin{array}{l}\text { Trueman, Dr. A. W. } \\
\text { [Albert William] }\end{array}$ & President, Univ. of Manitoba & Winnipeg \\
\hline $\begin{array}{l}\text { Rhodenizer, V. B. } \\
\text { [Vernon Blair] }\end{array}$ & Prof, Acadia University & Wolfville, NS \\
\hline
\end{tabular}

\begin{tabular}{|l|l|l|}
\hline \multicolumn{3}{|c|}{ Judges in 1947 for books written during 1946 } \\
\hline \multicolumn{3}{|c|}{ Fiction } \\
\hline Rutledge, Joseph Lister & Publisher of Liberty & Toronto \\
\hline Jennings, Charles & general supervisor of programs for the CBC & Toronto \\
\hline Dilworth, Ira & superintendent of CBC for BC & Vancouver \\
\hline \multicolumn{3}{|c|}{ Poetry } \\
\hline $\begin{array}{l}\text { Brown, E. K. } \\
\text { [Edward Killoran] }\end{array}$ & $\begin{array}{l}\text { author of On Canadian Poetry, with Univ. of } \\
\text { Chicago }\end{array}$ & \\
\hline Birney, Earle & $\begin{array}{l}\text { editor of Canadian Poetry Magazine, at Univ. } \\
\text { of British Columbia }\end{array}$ & \\
\hline Cox, Leo & Montreal advertising exec and poet & \\
\hline \multicolumn{3}{|c|}{ Creative Non-Fiction } \\
\hline Kennedy, Roderick S. & $\begin{array}{l}\text { Editor-in-chief of Family Herald and Weekly } \\
\text { Star }\end{array}$ & Montreal \\
\hline Crouch, Richard & chief Librarian of London Public Library & London, On \\
\hline Roberts, Dr. Marguerite & Dept. of English, University of Toronto & \\
\hline \multicolumn{1}{|c|}{ Academic Non-Fiction } & \\
\hline Smith, Dr. Sidney & President of University of Toronto & \\
\hline
\end{tabular}




\begin{tabular}{|l|l|l|}
\hline $\begin{array}{l}\text { Trueman, Dr. A. W. } \\
\text { [Albert William] }\end{array}$ & President of University of Manitoba & \\
\hline $\begin{array}{l}\text { MacKenzie, Dr. N. A. M. } \\
\text { [Norman Archibald }\end{array}$ & & \\
MacRae] & President of University of British Columbia & \\
\hline
\end{tabular}

\begin{tabular}{|c|c|c|}
\hline \multicolumn{3}{|c|}{ Judges in 1948 for books written during 1947} \\
\hline \multicolumn{3}{|c|}{ Fiction } \\
\hline Rutledge, Joseph Lister & editor of Canadian Author and Bookman & \\
\hline Roberts, Dr. Marguerite & University of Richmond & Virginia \\
\hline Jennings, Charles & talks director of $\mathrm{CBC}$ & \\
\hline \multicolumn{3}{|c|}{ Poetry } \\
\hline $\begin{array}{l}\text { Brown, E. K. } \\
\text { [Edward Killoran] }\end{array}$ & Professor of English, University of Chicago & Chicago \\
\hline Birney, Earle & $\begin{array}{l}\text { editor of Canadian Poetry Magazine, prof. of } \\
\text { English at UBC }\end{array}$ & Vancouver \\
\hline Cox, Leo & poet and advertising executive & Montreal \\
\hline \multicolumn{3}{|c|}{ Creative Non-Fiction } \\
\hline Kennedy, Roderick Stuart & $\begin{array}{l}\text { editor-in-chief of Family Herald and Weekly } \\
\text { Star }\end{array}$ & Montreal \\
\hline Crouch, Richard & chief librarian of London, ON, public library & London \\
\hline Sanderson, Charles R & \multirow{2}{*}{$\begin{array}{l}\text { chief librarian of Toronto Public Libraries } \\
\text { [Sanderson]; literary editor of The Standard } \\
\text { [Watt] }\end{array}$} & \multirow{2}{*}{$\begin{array}{l}\text { Toronto; } \\
\text { Montreal }\end{array}$} \\
\hline Watt, Sholto & & \\
\hline \multicolumn{3}{|c|}{ Academic Non-Fiction } \\
\hline $\begin{array}{l}\text { MacKenzie, N. A. M. } \\
\text { [Norman Archibald } \\
\text { MacRae] }\end{array}$ & president of UBC & \\
\hline $\begin{array}{l}\text { Trueman, A. W. } \\
\text { [Albert William] }\end{array}$ & president of University of Manitoba & \\
\hline Talman, James J. & librarian of the University of Western Ontario & \\
\hline
\end{tabular}

*Note: Sanderson and Watt worked in collaboration.

\begin{tabular}{|l|l|l|}
\hline \multicolumn{3}{|c|}{ Judges in 1949 for books written during 1948} \\
\hline \multicolumn{3}{|c|}{ Fiction } \\
\hline Kennedy, Roderick Stuart & $\begin{array}{l}\text { editor-in-chief of Family Herald and Weekly } \\
\text { Star }\end{array}$ & \\
\hline Roberts, Dr. Marguerite & $\begin{array}{l}\text { dean of women at Westhampton College, } \\
\text { University of Richmon (Virginia) }\end{array}$ & \\
\hline Jennings, Charles & CBC executive & Poetry \\
\hline \multicolumn{2}{|c|}{ Toronto } \\
\hline Birney, Earle & prof. at UBC & Ottawa \\
\hline Bourinot, Arthur S. & $\begin{array}{l}\text { lawyer and poet, editor of Canadian Poetry } \\
\text { Magazine }\end{array}$ & \\
\hline $\begin{array}{l}\text { Brown, E. K. } \\
\text { [Edward Killoran] }\end{array}$ & \begin{tabular}{l} 
Professor of English, University of Chicago \\
\hline
\end{tabular}
\end{tabular}




\begin{tabular}{|l|l|l|}
\hline \multicolumn{3}{|c|}{ Creative Non-Fiction } \\
\hline Graves, Sandham & editor of Victoria Colonist & \\
\hline Crouch, Richard & chief librarian of the London Public Library & \\
\hline Elliott, John K. & editorial writer for London Free Press & \\
\hline \multicolumn{2}{|c|}{ Academic Non-Fiction } & \\
\hline $\begin{array}{l}\text { MacKenzie, N. A. M. } \\
\text { [Norman Archibald } \\
\text { MacRae] }\end{array}$ & president of UBC & \\
\hline $\begin{array}{l}\text { Trueman, A. W. } \\
\text { [Albert William] }\end{array}$ & president of University of New Brunswick & \\
\hline $\begin{array}{l}\text { MacOdrum, M. M. } \\
\text { [Murdoch Maxwell] }\end{array}$ & principal of Carleton College & Ottawa \\
\hline
\end{tabular}

\begin{tabular}{|c|c|c|}
\hline \multicolumn{3}{|c|}{ Judges in 1950 for books written during 1949} \\
\hline \multicolumn{3}{|c|}{ Fiction } \\
\hline Deacon, William Arthur & Literary Editor, Globe \& Mail & \\
\hline Elliot, John K. & Literary Editor, London Free Press & \\
\hline Kennedy, Roderick Stuart & $\begin{array}{l}\text { Managing Editor, Family Herald and Weekly } \\
\text { Star }\end{array}$ & Montreal \\
\hline \multicolumn{3}{|c|}{ Poetry } \\
\hline Birney, Dr. Earle & Professor of English, UBC & \\
\hline $\begin{array}{l}\text { Brown, Dr. E. K. } \\
\text { [Edward Killoran] }\end{array}$ & Professor of English, University of Chicago & \\
\hline Bruce, Charles & General Superintendent, Canadian Press & Toronto \\
\hline \multicolumn{3}{|c|}{ Creative Non-Fiction } \\
\hline Crouch, Richard & Chief Librarian, London Public Library & \\
\hline Graves, Sandham & Editor, Victoria Colonist & \\
\hline Yocom, John & Managing Editor, Saturday Night & Toronto \\
\hline \multicolumn{3}{|c|}{ Academic Non-Fiction } \\
\hline $\begin{array}{l}\text { MacKenzie, Dr. N. A. M. } \\
\text { [Norman Archibald } \\
\text { MacRae] }\end{array}$ & President of UBC & \\
\hline $\begin{array}{l}\text { MacOdrum, Dr. M. M. } \\
\text { [Murdoch Maxwell] }\end{array}$ & President of Carleton College & \\
\hline $\begin{array}{l}\text { Rhodenizer, Dr. V. B. } \\
\text { [Vernon Blair] }\end{array}$ & Professor of English, Acadia University & Wolfville \\
\hline \multicolumn{3}{|c|}{ Juvenile } \\
\hline $\begin{array}{l}\text { Farquharson, R. A. } \\
\text { [Robert Alan] }\end{array}$ & Managing Editor, Globe \& Mail & \\
\hline $\begin{array}{l}\text { Jacobson, Mrs. Percy } \\
\text { [May Jacobson] }\end{array}$ & juveniles authority & Montreal \\
\hline Weekes, Mrs. Mary & noted juvenile author & Regina \\
\hline
\end{tabular}

Judges in 1951 for books written during 1950 


\begin{tabular}{|c|c|c|}
\hline \multicolumn{3}{|c|}{ Fiction } \\
\hline Deacon, William Arthur & Literary Editor, Globe \& Mail & \\
\hline Elliot, John K. & Literary Editor, London Free Press & \\
\hline Scott, James & Literary Editor, The Telegram [Toronto] & \\
\hline \multicolumn{3}{|c|}{ Poetry } \\
\hline Birney, Dr. Earle & Professor of English, UBC & \\
\hline $\begin{array}{l}\text { Brown, Dr. E. K. } \\
\text { [Edward Killoran] }\end{array}$ & Profess of English, University of Chicago & \\
\hline Bruce, Charles & General Superintendent, Canadian Press & \\
\hline \multicolumn{3}{|c|}{ Creative Non-Fiction } \\
\hline Rankin, R. J. & $\begin{array}{l}\text { Managing Editor, Chronicle-Herald and } \\
\text { Mail-Star }\end{array}$ & Halifax \\
\hline Stiling, Dr. Frank & $\begin{array}{l}\text { Assistnat Principal, University College, } \\
\text { University of Western Ontario }\end{array}$ & \\
\hline Yocom, John & Managing Editor, Saturday Night & \\
\hline \multicolumn{3}{|c|}{ Academic Non-Fiction } \\
\hline $\begin{array}{l}\text { MacKenzie, Dr. N. A. M. } \\
\text { [Norman Archibald } \\
\text { MacRae] }\end{array}$ & President, UBC & \\
\hline $\begin{array}{l}\text { MacOdrum, Dr. M. M. } \\
\text { [Murdoch Maxwell] }\end{array}$ & President, Carleton College & \\
\hline $\begin{array}{l}\text { Trueman, Dr. A. W. } \\
\text { [Albert William] }\end{array}$ & President, University of New Brunswick & Fredericton \\
\hline \multicolumn{3}{|c|}{ Juvenile } \\
\hline $\begin{array}{l}\text { Farquharson, R. A. } \\
\text { [Robert Alan] }\end{array}$ & Managing Editor, Globe \& Mail & \\
\hline $\begin{array}{l}\text { Lambert, R. S. } \\
\text { [Richard Stanton] }\end{array}$ & Supervisor, School Broadcasts, CBC & Toronto \\
\hline Weekes, Mrs. Mary & well-known juvenile authority & Regina \\
\hline
\end{tabular}

\begin{tabular}{|l|l|l|}
\hline \multicolumn{3}{|c|}{ Judges in 1952 for books written during 1951 } \\
\hline Elliot, John & literary editor, London Free Press & \\
\hline Hatfield, G. D. H. & \multicolumn{1}{|c|}{ Poetry } & Halifax \\
\hline Scott, James & Toronto Telegram & \\
\hline \multicolumn{3}{|c|}{ Ottawa } \\
\hline Bourinot, Arthur S. & editor of Canadian Poetry Magazine & Toronto \\
\hline Fisher, Prof. J. [Jospeh] & Victoria College & \\
\hline $\begin{array}{l}\text { Phelps, Prof. A. L. } \\
\text { [Arthur] }\end{array}$ & McGill & \\
\hline \multicolumn{3}{|c|}{ Creative Non-Fiction } \\
\hline Rankin, R. J. & managing editor, The Halifax Herald & \\
\hline Stiling, Dr. Frank & University of Western Ontario & \\
\hline Vocom, Dr. John & managing editor, Saturday Night & \\
\hline \multicolumn{1}{|c|}{ Academic Non-Fiction } \\
\hline MacKenzie, Dr. N. A. M. & University of British Columbia & \\
\hline
\end{tabular}




\begin{tabular}{|l|l|l|}
\hline $\begin{array}{l}\text { [Norman Archibald } \\
\text { MacRae] }\end{array}$ & \\
\hline $\begin{array}{l}\text { MacOdrum, Dr. M. M. } \\
\text { [Murdoch Maxwell] }\end{array}$ & Carleton College & \\
\hline $\begin{array}{l}\text { Trueman, Dr. A. W. } \\
\text { [Albert William] }\end{array}$ & Univesity of New Brunswick & \\
\hline \multicolumn{2}{|c|}{ Juvenile } \\
\hline Dickie, Donalda & \multicolumn{1}{|c|}{} \\
\hline $\begin{array}{l}\text { Lambert, R. S. } \\
\text { [Richard Stanton] }\end{array}$ & CBC & Vancouver \\
\hline McManus, Herbert & Saturday Night & Toronto \\
\hline
\end{tabular}

\begin{tabular}{|c|c|c|}
\hline \multicolumn{3}{|c|}{ Judges in 1953 for books written during 1952} \\
\hline \multicolumn{3}{|c|}{$\begin{array}{c}\text { Fiction } \\
\end{array}$} \\
\hline Elliot, John K. & assistant editor-in-chief, London Free Press & \\
\hline $\begin{array}{l}\text { Beresford-Howe, } \\
\text { Constance }\end{array}$ & English Department, McGill University & \\
\hline Scott, James & $\begin{array}{l}\text { English department, University of Western } \\
\text { Ontario }\end{array}$ & \\
\hline \multicolumn{3}{|c|}{ Poetry } \\
\hline Bruce, Charles & general superintendent, Canadian Press & \\
\hline $\begin{array}{l}\text { Alexander, } \mathrm{H} . \\
\text { [Henry] }\end{array}$ & English department, Queen's University & \\
\hline $\begin{array}{l}\text { Phelps, A. L. } \\
\text { [Arthur] }\end{array}$ & English department, McGill University & \\
\hline \multicolumn{3}{|c|}{ Creative Non-Fiction } \\
\hline $\begin{array}{l}\text { Leechman J. D. } \\
\text { [John Douglas] }\end{array}$ & National Museum & Ottawa \\
\hline $\begin{array}{l}\text { Morrow, Prof. E. H. } \\
\text { [Ellis] }\end{array}$ & UBC & \\
\hline Reaman, George E. & $\begin{array}{l}\text { head of department of English, Ontario } \\
\text { Agricultural College }\end{array}$ & \\
\hline \multicolumn{3}{|c|}{ Academic Non-Fiction } \\
\hline $\begin{array}{l}\text { MacOdrum, M. M. } \\
\text { [Murdoch Maxwell] }\end{array}$ & president, Carleton College & \\
\hline $\begin{array}{l}\text { Trueman, A. W. } \\
\text { [Albert William] }\end{array}$ & president, University of New Brunswick & \\
\hline $\begin{array}{l}\text { MacKenzie, N. A. M. } \\
\text { [Norman Archibald } \\
\text { MacRae] }\end{array}$ & president, UBC & \\
\hline \multicolumn{3}{|c|}{ Juvenile } \\
\hline McManus, Herbert J. & managing editor, Saturday Night & \\
\hline Hayes, John F. & Southam Press, winner in 1951 & Montreal \\
\hline Dickie, Donalda & educationist, winner in 1950 & \\
\hline
\end{tabular}




\begin{tabular}{|c|c|c|}
\hline \multicolumn{3}{|c|}{ Judges in 1954 for books written during 1953} \\
\hline \multicolumn{3}{|c|}{ Fiction } \\
\hline $\begin{array}{l}\text { Nichols, M. E. } \\
\text { [Mark Edgar] }\end{array}$ & former journalist & Vancouver \\
\hline Bissell, Claude T. & $\begin{array}{l}\text { editor of fiction section of University of } \\
\text { Queen's Quarterly annual review of } \\
\text { "Canadian Letters" }\end{array}$ & \\
\hline $\begin{array}{l}\text { Beresford-Howe, } \\
\text { Constance }\end{array}$ & Novelist & \\
\hline \multicolumn{3}{|c|}{ Poetry } \\
\hline Daniells, Roy & University of British Columbia & \\
\hline Alexander, H. [Henry] & Queen's University & \\
\hline Child, Philip & Trinity & \\
\hline \multicolumn{3}{|c|}{ Creative Non-Fiction } \\
\hline Allen, W. Graham & & Halifax \\
\hline $\begin{array}{l}\text { Stobie, Mrs. W. G. } \\
\text { (Margaret) }\end{array}$ & & Winnipeg \\
\hline Reaman, G. E. [George] & & Guelph \\
\hline \multicolumn{3}{|c|}{ Academic Non-Fiction } \\
\hline $\begin{array}{l}\text { Bennet, C. L. } \\
\text { [Charles Lindsay] }\end{array}$ & Dalhousie University & \\
\hline $\begin{array}{l}\text { Allen, R. A. } \\
\text { [Ronald Alexander] }\end{array}$ & University of Western Ontario & \\
\hline Johns, Walter & University of Alberta & \\
\hline \multicolumn{3}{|c|}{ Juvenile } \\
\hline Pacey, Desmond & University of New Brunswick & \\
\hline McManus, Herbert & Saturday Night & \\
\hline Crooks, Grace & Regional Library, Prince Albert & \\
\hline
\end{tabular}

\begin{tabular}{|c|c|c|}
\hline \multicolumn{3}{|c|}{ Judges in 1955 for books written during 1954} \\
\hline \multicolumn{3}{|c|}{ Fiction } \\
\hline $\begin{array}{l}\text { Bissell, C. T. } \\
\text { [Claude Thomas] }\end{array}$ & Vice-president, University of Toronto & \\
\hline Deacon, William Arthur & literary editor, Globe \& Mail & \\
\hline $\begin{array}{l}\text { Nichols, M. E. } \\
\text { [Mark Edgar] }\end{array}$ & & Vancouver \\
\hline \multicolumn{3}{|c|}{ Poetry } \\
\hline $\begin{array}{l}\text { Alexander, H. G. } \\
\text { [Henry] }\end{array}$ & Queen's University & \\
\hline Daniells, Roy & University of British Columbia & \\
\hline Dilworth, Ira & director for Ontario, CBC & \\
\hline \multicolumn{3}{|c|}{ Creative Non-Fiction } \\
\hline Allen, W. Graham & Dalhousie University & \\
\hline Boone, Maurice P. & Legislative librarian & $\begin{array}{l}\text { New } \\
\text { Brunswick }\end{array}$ \\
\hline Reaman, G. E. [George] & department of English, Ontario Agricultural & \\
\hline
\end{tabular}




\begin{tabular}{|c|c|c|}
\hline & College & \\
\hline \multicolumn{3}{|c|}{ Academic Non-Fiction } \\
\hline $\begin{array}{l}\text { Allen, R. A. } \\
\text { [Ronald Alexander] }\end{array}$ & vice-president, University of Western Ontario & \\
\hline $\begin{array}{l}\text { Bennet, C. L. } \\
\text { [Charles Lindsay] }\end{array}$ & Dalhousie University & \\
\hline Johns, Walter & $\begin{array}{l}\text { dean of arts and science, University of } \\
\text { Alberta }\end{array}$ & \\
\hline \multicolumn{3}{|c|}{ Juvenile } \\
\hline Crooks, Grace & $\begin{array}{l}\text { children's librarian, Saskatchewan regional } \\
\text { library }\end{array}$ & \\
\hline Hayes, John F. & winner of the award in 1951 and 1953 & \\
\hline McManus, Herbert & managing editor, Saturday Night & \\
\hline
\end{tabular}

\begin{tabular}{|c|c|c|}
\hline \multicolumn{3}{|c|}{ Judges in 1956 for books written during 1955} \\
\hline \multicolumn{3}{|c|}{ Fiction } \\
\hline Fraser, Blair & Ottawa editor of Maclean's & \\
\hline $\begin{array}{l}\text { Nichols, M. E. } \\
\text { [Mark Edgar] }\end{array}$ & & Vancouver \\
\hline $\begin{array}{l}\text { Woodside, Mrs. M. St. A. } \\
\text { [Moffat St. Andrew; } \\
\text { Eleanor Agnes Barton] }\end{array}$ & & Toronto \\
\hline \multicolumn{3}{|c|}{ Poetry } \\
\hline Alexander, H. G. [Henry] & Queen's University & \\
\hline Daniells, Roy & University of British Columbia & \\
\hline Dilworth, Ira & director for Ontario, $\mathrm{CBC}$ & \\
\hline \multicolumn{3}{|c|}{ Creative Non-Fiction } \\
\hline Allen, W. Graham & Dalhousie University & \\
\hline Boone, Maurice P. & Legislative librarian & $\begin{array}{l}\text { New } \\
\text { Brunswick }\end{array}$ \\
\hline O'Hearn, Walter & Montreal Star & \\
\hline \multicolumn{3}{|c|}{ Academic Non-Fiction } \\
\hline $\begin{array}{l}\text { Allen, R. A. } \\
\text { [Ronald Alexander] }\end{array}$ & vice-president, University of Western Ontario & \\
\hline $\begin{array}{l}\text { Bennet, C. L. } \\
\text { [Charles Lindsay] }\end{array}$ & Dalhousie University & \\
\hline Johns, Walter H. & $\begin{array}{l}\text { dean of arts and science, University of } \\
\text { Alberta }\end{array}$ & \\
\hline \multicolumn{3}{|c|}{ Juvenile } \\
\hline Crooks, Grace & $\begin{array}{l}\text { children's librarian, Saskatchewan regional } \\
\text { library }\end{array}$ & \\
\hline $\begin{array}{l}\text { Creighton, Mrs. John } \\
\text { (Sally) }\end{array}$ & & Vancouver \\
\hline McManus, Herbert & managing editor, Saturday Night & \\
\hline
\end{tabular}




\begin{tabular}{|c|c|c|}
\hline Stiling, Dean Frank & University of Western Ontario & \\
\hline Ross, Prof. Malcolm & Queen's University & \\
\hline $\begin{array}{l}\text { McDougall, Prof. R. L. } \\
\text { [Robert] }\end{array}$ & University of Toronto & \\
\hline \multicolumn{3}{|c|}{ Poetry } \\
\hline $\begin{array}{l}\text { Alexander, Prof. H. } \\
\text { [Henry] }\end{array}$ & Queen's University & \\
\hline Dilworth, Dr. Ira & $\mathrm{CBC}$ & Toronto \\
\hline Daniells, Prof. Roy & University of British Columbia & \\
\hline \multicolumn{3}{|c|}{ Creative Non-Fiction } \\
\hline O'Hearn, Walter & Montreal Star & \\
\hline Allen, W. Graham & Dalhousie University & \\
\hline Boone, Maurice & Legislative librarian & $\begin{array}{l}\text { New } \\
\text { Brunswick }\end{array}$ \\
\hline \multicolumn{3}{|c|}{ Academic Non-Fiction } \\
\hline Johns, Dean Walter H. & University of Alberta & \\
\hline $\begin{array}{l}\text { Bennet, C. L. } \\
\text { [Charles Lindsay] }\end{array}$ & Dalhousie University & \\
\hline $\begin{array}{l}\text { Allen, Dr. R. A. } \\
\text { [Ronald Alexander] }\end{array}$ & vice-president, University of Western Ontario & \\
\hline \multicolumn{3}{|c|}{ Juvenile } \\
\hline $\begin{array}{l}\text { Creighton, Mrs. John } \\
\text { [Sally] }\end{array}$ & & Vancouvel \\
\hline Vansickle, Reata M. & St. Catharines Public Library & \\
\hline Crooks, Grace & Orillia Public Library & \\
\hline
\end{tabular}

\begin{tabular}{|c|c|c|}
\hline \multicolumn{3}{|c|}{ Judges in 1958 for books written during 1957} \\
\hline \multicolumn{3}{|c|}{ Fiction } \\
\hline $\begin{array}{l}\text { Klinck, Dr. C. F. } \\
\text { [Carl Frederick] }\end{array}$ & University of Western Ontario & \\
\hline $\begin{array}{l}\text { McDougall, Prof. Robert } \\
\text { L. }\end{array}$ & Carleton University & \\
\hline Ross, Prof. Malcolm & Queen's University & \\
\hline \multicolumn{3}{|c|}{ Poetry } \\
\hline Daniells, Prof. Roy & University of British Columbia & \\
\hline Dilworth, Ira & $\mathrm{CBC}$ & Toronto \\
\hline Whalley, George & Queen's University & \\
\hline \multicolumn{3}{|c|}{$\begin{array}{l}\text { Creative Non-Fiction } \\
\end{array}$} \\
\hline Boone, Maurice & Legislative Library & Fredericton \\
\hline Allen, W. Graham & $\mathrm{CBC}$ & Halifax \\
\hline O'Hearn, Walter & Montreal Star & \\
\hline $\begin{array}{l}\text { Wild, Prof. J. L. } \\
\text { [John Leslie] }\end{array}$ & University of Western Ontario & \\
\hline \multicolumn{3}{|c|}{$\begin{array}{l}\text { Academic Non-Fiction } \\
\text { University of Western Ontario }\end{array}$} \\
\hline Allen, Dr. Ronald A. & University of Western Ontario & \\
\hline
\end{tabular}




\begin{tabular}{|l|l|l|}
\hline Johns, Dr. Walter H. & University of Alberta & \\
\hline $\begin{array}{l}\text { Bennet, Prof. C. L. } \\
\text { [Charles Lindsay] }\end{array}$ & Dalhouise University & \multicolumn{1}{|c|}{ Juvenile } \\
\hline \multicolumn{2}{|l|}{} & \\
\hline Vansickle, Miss Reata M. & St. Catharines Public Library & Vancover \\
\hline $\begin{array}{l}\text { Creighton, Mrs. John } \\
\text { [Sally] }\end{array}$ & & \\
\hline Crooks, Miss Grace & Orillia Public Library & \\
\hline
\end{tabular}

\begin{tabular}{|c|c|c|}
\hline \multicolumn{3}{|c|}{ Judges in 1959 for books written during 1958} \\
\hline \multicolumn{3}{|c|}{ Fiction } \\
\hline Klinck, Dr. Carl F. & University of Western Ontario & \\
\hline Ross, Prof. Malcolm & Queen's University & \\
\hline Peel, Bruce & University of Alberta & \\
\hline $\begin{array}{l}\text { Poole, W. R. } \\
\text { [William Robert] }\end{array}$ & & London \\
\hline \multicolumn{3}{|c|}{ Poetry } \\
\hline Dilworth, Dr. Ira & & Vancouver \\
\hline Daniells, Prof. Roy & University of British Columbia & \\
\hline Whalley, Prof. George & Queen's University & \\
\hline \multicolumn{3}{|c|}{ Creative Non-Fiction } \\
\hline Boone, Maurice P. & Legislative Library & Fredericton \\
\hline Allen, W. Graham & $\mathrm{CBC}$ & Halifax \\
\hline McLintock, Peter & Winnipeg Free Press & \\
\hline \multicolumn{3}{|c|}{ Academic Non-Fiction } \\
\hline $\begin{array}{l}\text { Bennet, Prof. C. L. } \\
\text { [Charles Lindsay] }\end{array}$ & Dalhousie University & \\
\hline Balderston, Walter & University of Western Ontario & \\
\hline $\begin{array}{l}\text { Dorland, Dr. A. G. } \\
\text { [Arthur Garratt] }\end{array}$ & & Toronto \\
\hline $\begin{array}{l}\text { Kerr, Prof. D. G. } \\
\text { [Donald Gordon Grady] }\end{array}$ & University of Western Ontario & \\
\hline \multicolumn{3}{|c|}{ Juvenile } \\
\hline Vansickle, Reata M. & librarian, St. Catharines & \\
\hline Creighton, Sally & CBC reviewer of children's books & Vancouver \\
\hline Crooks, Grace & librarian & Orillia, ON \\
\hline
\end{tabular}

*Note: The judges in the categories of Fiction and Academic Non-Fiction had difficulties coming to a decision, so a fourth judge was added in each category. 


\section{Appendix II \\ Point System for Evaluating Votes of the Judges}

(Version adopted in March 1945)

Operation 1. :

Each title placed first by a judge shall be credited with 7 points.

Each title placed second by a judge shall be credited with 5 points.

Each title placed third by a judge shall be credited with 2 points.

Operation 2. :

To the above primary marking shall be added secondary points, representing consensus of the judges as follows:

5 points added for 3 votes in either first or second place

4 points added for 3 votes including at least one first or second [place]

3 points added for 3 votes all thirds

3 points added for 2 votes in either first or second place

2 points added for 2 votes including one third

1 point added for 2 votes both thirds

Winner shall be the book credited with greatest number of points - primary plus secondary. Thus a unanimous selection rates $3 \times 7$ plus 5, equals 26 points; and the lowest count is 2 points for a single judge naming a book in third spot (It does not rate any bonus).

(Version adopted in 1951)

Note: This new version was adopted "due to the circumstances that two first-place votes could be invalidated by one first and two second-place votes, thereby inflicting an obvious hardship upon the author of the book that received two first-place votes."13

(a) Ten (10) points for each first vote.

Five (5) points for each second vote.

Two (2) points for each third vote.

All plus bonus points as follows:

(b) Bonuses:

Seven points for two votes in first place.

Five points for three votes, one in first and two in second place.

Four points for three votes which are all seconds.

Four points for three votes including one first or second.

\footnotetext{
${ }^{13}$ Franklin Davey McDowell. “Governor General’s Awards Board. Chairman’s Report, Years 1949-1951, inclusive."
} 
Three points for three votes which are all thirds.

Three points for two votes in either first or second place.

Two points for two votes including one third.

One point for two votes which are both third. 


\section{Works Cited}

\section{Archival Sources Consulted:}

Canadian Authors Association Fonds. Library and Archives Canada.

Charles Clay Fonds. Library and Archives Canada.

Earle Birney Fonds. Ms Coll 49. Thomas Fisher Rare Book Library. University of Toronto.

J.L. Granastein Fonds. Box 1995-0037/001, File 06. York University Libraries, Clara Thomas Archives and Special Collections.

Royal Commission on National Development in the Arts, Letters and Sciences Fonds. Library and Archives Canada.

William Arthur Deacon Fonds. Ms. Coll. 160. Thomas Fisher Rare Book Library. University of Toronto.

"An Act for the Establishment of a Canada Council for the Encouragement of the Arts, Humanities and Social Sciences." Acts of the Parliament of Canada. Ottawa: Edmond Cloutier, 1957. 17-22. Print.

Allison, W. T. "President's Address.” Authors' Bulletin 5.1 (1927): 3-5. Print.

“Annual Meeting Resolutions.” Canadian Author and Bookman 20.3 (1944): 11-3. Print. Anstee, Cameron. "“Poet and Audience Actually Exist': The Contact Poetry Reading Series and the Rise of Literary Readings in Canada.” Journal of Canadian Studies 49.1 (2015): 73-94. Print. 
---. "Setting Widespread Precedent: The Canada Council for the Arts and the Funding of Poetry Readings in Canada (1957-1977).” Amodern 4 (2015): n. pag. Web. 29 Apr. 2016.

Appleton, F. F. “Book Week Suggestions.” Canadian Bookman 3.2 (1921): 46-7. Print.

"The Arts Stand Mobilized." Canadian Author \& Bookman 20.4 (1944): 24. Print.

Atwood, Margaret. "Writers' Union of Canada." Canadian Encyclopedia. 2 July 2006. Web. 20 Mar. 2016.

“Authorship and Copyright.” Editorial. Canadian Forum 1.8 (1921): 230. Print.

Ayre, Robert. "The Press Debates the Massey Report." Canadian Art 9.1 (1951): 25-30, 36-8. Print.

Bannerman, Sara. The Struggle for Canadian Copyright: Imperialism to Internationalism, 1842-1971. Vancouver: U of British Columbia P, 2013. Print. Barnard, Leslie Gordon. "Presidential Address.” Canadian Author 16.3 (1939): 6-9. Print.

Bell, Michael Davitt. "Beginnings of Professionalism." Culture, Genre, and Literary Vocation: Selected Essays on American Literature. Chicago: U of Chicago P, 2001. 67-133. Print.

Berland, Jody. "Nationalism and the Modernist Legacy: Dialogues with Innis." Capital Culture: A Reader on Modernist Legacies, State Institutions, and the Value(s) of Art. Ed. Jody Berland and Shelley Hornstein. Montreal: McGill-Queen's UP, 2000. 14-38. Print.

Birney, Earle. Letter to William Arthur Deacon. 26 Mar. 1946. Earle Birney Fonds. Box 30, File 18. 
---. Letter to William Deacon. 24 July 1946. Earle Birney Fonds. Box 30, File 18.

---. Spreading Time: Remarks on Canadian Writing and Writers. Montreal: Véhicule P, 1980. Print.

Bissell, Claude T. "Letters in Canada: Fiction.” University of Toronto Quarterly 24.3 (1955): 257-66. Print.

Bonham-Carter, Victor. Authors by Profession. Vol. 1. Los Altos, CA: William Kaufmann, 1978. Print.

“The Book Fair, and After." Canadian Author 14.2 (1936): 6-7. Print.

"Book Week.” Editorial. Canadian Forum 2.14 (1921): 422. Print.

"Book Week-And After." Canadian Author 13.1 (1935): 6. Print.

“Book Week—or Else?” Authors' Bulletin 9.3 (1932): 2. Print.

“Book Week Nov. 5-12” Editorial. Authors' Bulletin 10.1 (1932): 3-4. Print.

"Bookishness in Canada." Editorial. Canadian Bookman 1.1 (1919): n. pag. Print.

Bourdieu, Pierre. The Field of Cultural Production: Essays on Art and Literature. Ed. Randal Johnson. New York: Columbia UP, 1993. Print.

---. "The Forms of Capital." Handbook of Theory and Research for the Sociology of Education. Ed. John G. Richardson. New York: Greenwood Press, 1986. 241-58. Print.

---. "The Social Space and the Genesis of Groups." Theory and Society 14.6 (1985): 72344. Print.

Brandt, Di. “A New Genealogy of Canadian Literary Modernism.” Wider Boundaries of Daring: The Modernist Impulse in Canadian Women's Poetry. Waterloo: Wilfrid Laurier UP, 2009. 1-28. Print. 
Breitbach, Julia. "Politics and Literature between Nationalism and Internationalism." History of Literature in Canada: English-Canadian and French-Canadian. Ed. Reingard M. Nischik. Rochester, NY: Camden House, 2008. 149-58. Print.

Brode, Bride. "Woman's Point of View: Memorial to Seranus." The Globe and Mail 12 June 1937: 15. Print.

Cambron, Micheline and Carole Gerson. "Literary Authorship." History of the Book in Canada. Vol. 2. Ed. Yvan Lamonde, Patricia Lockhart Fleming, and Fiona A. Black. Toronto: U of Toronto P, 2005. 119-34. Print.

Canada. House of Commons. Official Report of Debates House of Commons. $13^{\text {th }}$ Parl., $5^{\text {th }}$ sess. 5 vols. Ottawa: F. A. Acland, 1921. Print.

---. House of Commons. Official Report of Debates House of Commons. $14^{\text {th }}$ Parl., $2^{\text {nd }}$ sess. 5 vols. Ottawa: F. A. Acland, 1923. Print.

---. House of Commons. Special Committee on Reconstruction and Re-Establishment: Minutes of Proceedings and Evidence, No. 10. June 21, 1944. Ottawa: Edmond Cloutier, 1944. Print.

---. House of Commons. Special Committee. Proceedings of the Special Committee Appointed to Consider and Report Upon Bill No. 2, an Act to Amend and Make Operative Certain Provisions of the Copyright Act, 1921. Ottawa: F. A. Acland, 1925. Print.

---. Senate. Debates of the Senate. $13^{\text {th }}$ Parl., $2^{\text {nd }}$ sess. Ottawa: F. A. Acland, 1921. Print. ---. Senate. Debates of the Senate. $13^{\text {th }}$ Parl., $5^{\text {th }}$ sess. Ottawa: F. A. Acland, 1921. Print. Canada Council. The Canada Council Fifth Annual Report 1961-62. Ottawa: Canada Council for the Arts, 1962. Print. 
---. The Canada Council: First Annual Report. Ottawa: Canada Council for the Arts, 1958. Print.

---. The Canada Council Fourth Annual Report for 1960-61. Ottawa: Canada Council for the Arts, 1961. Print.

---. Canada Council: Opening Proceedings, Ottawa, May 1957. Ottawa: Canada Council for the Arts, 1957. Print.

---. The Canada Council: Second Annual Report. Ottawa: Canada Council for the Arts, 1959. Print.

---. The Canada Council: Third Annual Report. Ottawa: Canada Council for the arts, 1960. Print.

“Canada’s Book Week.” Authors' Bulletin 9.1 (1931): 40. Print.

“Canada's Literary Movement: Do We Need a Few Heretics in Canada to Inject Some Originality Into Canadian Literature and Save it From the Plight of Being Commonplace?” Editorial. Manitoba Free Press 6 Oct. 1924: 5. Print.

Canadian Arts Council. "Brief to the Royal Commission on National Development in the Arts, Letters, and Sciences by the Canadian Arts Council." n. d. Royal Commission on National Development in the Arts, Letters and Sciences Fonds. Microfilm reel C-2002.

Canadian Authors Association. "Brief from the Canadian Authors Association to the Royal Commission on National Development in the Arts, Letters and Sciences.” 31 Oct. 1949. Royal Commission on National Development in the Arts, Letters and Sciences Fonds. Microfilm reel C-2002. 
Canadian Authors Association, Vancouver and Mainland Branch. "[Brief] To the Royal Commission on National Development in the Arts, Letters and Sciences" n. d. Royal Commission on National Development in the Arts, Letters and Sciences Fonds. Microfilm reel C-2002.

“Canadian Authors Plan to Organize." Globe [Toronto] 12 Mar. 1921: 3.

Canadian Bookman 4.1 (1921): Cover page. Print.

“Canadian Publishers Meet.” Publishers' Weekly 99.16 (1921): 1180. Print.

Canadian Writers' Committee. "Brief to the Royal Commission on National

Development in the Arts, Letters and Sciences from the Canadian Writers'

Committee." 31 Oct. 1949. Royal Commission on National Development in the

Arts, Letters and Sciences Fonds. Microfilm reel C-2006.

Canadian Writers' Committee. “[Minutes of Proceedings and Evidence by] Canadian Writers' Committee." n. d. Royal Commission on National Development in the Arts, Letters and Sciences Fonds. Microfilm reel C-2006.

Chairman of Membership Committee. Letter to Grace E. Budd. 29 Apr. 1932. Canadian Authors Association Fonds. Box 27, File 32.

Charleabois, R. H. Letter to Archibald A. Day. 8 June 1950. Royal Commission on National Development in the Arts, Letters and Sciences Fonds. Microfilm reel C2002.

Charvat, William. The Profession of Authorship in America, 1800-1870: The Papers of William Charvat. Ed. Matthew J. Bruccoli. Columbus: Ohio State UP, 1968. Print. 
Chesterton, G. K. “A Defence of Patriotism.” The Defendant. London: J. M. Dent and Sons, 1901. 163-72. Print.

Child, Philip. "Of Bread, Art, and Masterpieces.” Canadian Author and Bookman 21.4 (1945): 8-9. Print.

Claxton, Brooke. "Address by the Chairman of the Canada Council, the Honourable Brooke Claxton.” Canada Council: Opening Proceedings, Ottawa, May 1957. Ottawa: Canada Council, 1957. 8-15. Print.

Clay, Charles. Letter to William Arthur Deacon. 18 Mar. 1940. Charles Clay Fonds. Vol. 1, “W.A. Deacon” File.

“The Convention of Canadian Authors." Canadian Bookman 3.1 (1921): 8-13. Print.

“The Copyright Law.” Editorial. Canadian Bookman 2.3 (1920): 3-5. Print.

“Copyright, More or Less.” Editorial. Globe and Mail 16 Nov. 1977: 6. Print.

Coultrap-McQuin, Susan. Doing Literary Business: American Women Writers in the Nineteenth Century. Chapel Hill, NC: U of North Carolina P, 1990. Print.

Courtney, Richard. "The Arts in Canada-Re-play or Re-cognition?" Journal of the Royal Society for the Encouragement of Arts, Manufactures and Commerce 123 (1975): 659-67. Print.

Cunningham, Louis Arthur. “Authors and Authors.” Reply to letter of Leslie McFarlane. Mail and Empire 21 July 1931: 6. Print.

Curry, Ralph L. Stephen Leacock: Humorist and Humanist. New York: Doubleday, 1959. Print.

Darnton, Robert. “What Is the History of Books?” Daedalus 111.3 (1982): 65-83. Print. 
Davey, Frank. "Economics and the Writer.” Gerson and Michon 103-13.

Deacon, William Arthur. "Annual Awards Established to Aid Canadian Literature." Globe and Mail 27 Feb. 1937: 12. Print.

---. "The Arts in Canada Speak Out Before Parliamentary Committee." Globe and Mail 24 June 1944: 7. Print.

---. “Canadian Novels of 1954.” Globe and Mail 2 Apr. 1955: 13. Print.

---. "The Fly Leaf." Globe and Mail 9 Apr. 1955: 10. Print.

---. “The Fly Leaf.” Globe and Mail 9 July 1955: 34. Print.

---. "Gearing the Arts in Canada to Postwar Nation-Building." Globe and Mail 1 Jan. 1944: 13. Print.

---. “Governor-General's Awards Board Consults National Executive.” 11 Mar. 1949. William Arthur Deacon Fonds. Box 35A, File 3.

---. “Governor General's Awards Board Report." Canadian Author and Bookman [Supplement] 21.4 (1945): 26-7. Print.

---. "Leslie McFarlane, Author, is Invited to Conventions." Mail and Empire 11 July 1931: 8. Print.

---. Letter to A. W. Trueman. n.d. [1946]. William Arthur Deacon Fonds. Box 35A, File 10.

---. Letter to Albert Robson. 14 May 1935. William Arthur Deacon Fonds. Box 29, File 13.

---. Letter to Alexander Calhoun. 9 Mar. 1946. William Arthur Deacon Fonds. Box 35A, File 10. 
---. Letter to Arthur Phelps. 5 Feb. 1946. William Arthur Deacon Fonds. Box 35A, File 10.

---. Letter to B.K. Sandwell. 10 Sept. 1952. William Arthur Deacon Fonds. Box 35A, File 11.

---. Letter to Charles Clay. 13 Mar. 1940. Charles Clay Fonds. Vol. 1, "W.A. Deacon" File.

---. Letter to Charles Clay. 15 Oct. 1940. Charles Clay Fonds. Vol. 1, "W.A. Deacon" File.

---. Letter to Charles Sanderson and Fred Landon. 9 July 1944. William Arthur Deacon Fonds. Box 31, File 1.

---. Letter to Earle Birney. 29 Mar. 1946. Earle Birney Fonds. Box 30, File 18.

---. Letter to Earle Birney. 9 Aug. 1946. Earle Birney Fonds. Box 30, File 19.

---. Letter to Eric Gaskell. 9 Mar. 1939. William Arthur Deacon Fonds. Box 35A, File 11.

---. Letter to Eric Gaskell. Official. 18 Mar. 1939. William Arthur Deacon Fonds. Box 35A, File 11.

---. Letter to Eric Gaskell. Personal. 18 Mar. 1939. William Arthur Deacon Fonds. Box 35A, File 11.

---. Letter to Ira Dilworth. n.d. [1946]. William Arthur Deacon Fonds. Box 35A, File 10.

---. Letter to Ira Dilworth. 5 Feb. 1946. William Arthur Deacon Fonds. Box 35A, File 10.

---. Letter to J. Markowitz. 18 May 1946. William Arthur Deacon Fonds. Box 30, File 11.

---. Letter to Judges in Fiction Division. 26 Jan. 1946. William Arthur Deacon Fonds. Box 35A, File 10.

---. Letter to Kathleen Hobday. n.d. William Arthur Deacon Fonds. Box 30, File 9. 
---. Letter to Leslie Gordon Barnard. 16 Mar. 1939. William Arthur Deacon Fonds. Box 29, File 17.

---. Letter to Leo Cox. 5 Feb. 1946. William Arthur Deacon Fonds. Box 35A, File 10.

---. Letter to Margaret Clay. 19 Feb. 1946. William Arthur Deacon Fonds. Box 35A, File 10.

---. Letter to Mazo de la Roche. 9 Apr. 1947. William Arthur Deacon Fonds. Box 35A, File 7.

---. Letter to [Unknown]. n.d. William Arthur Deacon Fonds. Box 35A, File 3.

---. Letter to [Unknown]. "Strictly Confidential.” n.d. William Arthur Deacon Fonds. Box 35A, File 3.

---. Letter to Watson Kirkconnell. 18 Mar. 1944. William Arthur Deacon Fonds. Box 30, File 14.

---. Letter to Watson Kirkconnell. n.d. [1946]. William Arthur Deacon Fonds. Box 35A, File 10.

---. Poteen: A Pot-Pourri of Canadian Essays. Ottawa: Graphic Publishers, 1926. Print. ---. "Three Best Canadian Books." Globe and Mail 13 Apr. 1940: 11. Print.

Deshaye, Joel. The Metaphor of Celebrity: Canadian Poetry and the Public, 1955-1980. Toronto: U of Toronto P, 2013. Print.

Dilworth, Ira. Letter to William Arthur Deacon. 8 Apr. 1947. William Arthur Deacon Fonds. Box 35A, File 10.

“Don’t Overlook These Markets!” Canadian Author and Bookman 19.2 (1943): 20. Print. 
Dowler, Kevin. "The Cultural Industries Policy Apparatus." The Cultural Industries in Canada: Problems, Policies and Prospects. Ed. Michael Dorland. Toronto: James Lorimer, 1996. 328-46. Print.

Djwa, Sandra. The Politics of the Imagination: A Life of F.R. Scott. Toronto: McClelland and Stewart, 1987. Print.

Eayrs, Hugh S. "Renaissance in Canadian Life." Canadian Bookman 4.10 (1922): 263. Print.

Edgar, Pelham. "From the President." Canadian Author 13.1 (1935): 2. Print.

---. "Past Presidents' Forum." Canadian Author 16.3 (1939): 13-14. Print.

"Editorial." Canadian Author and Bookman 43.1 (1967): 3. Print.

English, James. "Winning the Culture Game: Prizes, Awards, and the Rules of Art." New Literary History 33.1 (2002): 109-35. Print.

Fairley, Barker. "Artists and Authors.” Canadian Forum 2.15 (1921): 460, 462-3. Print.

Fairley, Margaret. “Cold War Award.” Editorial. New Frontiers 4.2 (1955): 2. Print.

Fiddlehead Poetry Society. "Brief to the Royal Commission on National Development in the Arts, Letters and Sciences from the Fiddlehead Poetry Society.” n. d. Royal Commission on National Development in the Arts, Letters and Sciences Fonds. Microfilm reel C-2008.

Findley, Timothy. Rev. of Syllables of Recorded Time: The story of the Canadian Authors Association, 1921-1981, by Lyn Harrington. Globe and Mail 22 Aug. 1981: E15. Print.

First Statement Press. "Memorandum on the First Statement Press to the Members of the Royal Commission of the Arts, Sciences, Etc." n. d. Royal Commission on 
National Development in the Arts, Letters and Sciences Fonds. Microfilm reel C2008.

Fleming, Patricia. "Book History." Encyclopedia of Literature in Canada. Ed. William H. New. Toronto: U of Toronto P, 2002. 137-8. Print.

Foucault, Michel. "What Is an Author?" Textual Strategies: Perspectives in PostStructuralist Criticism. Ed. by Josué V. Harari. Ithaca, NY: Cornell UP, 1979. 141-60. Print.

French, Donald G. Letter to Anne Anderson Perry. 6 Mar. 1933. Canadian Authors Association Fonds. Box 27, File 33.

French, William. "In Solidarity." Globe and Mail 23 Apr. 1974: 12. Print.

---. "Writers' Convention a Farce: Most Professional Authors Stayed Away." Globe and Mail 1 Jul. 1967: 24. Print.

---. "Writers Take Fighting Stance." Globe and Mail 5 Nov. 1973: 14. Print.

---. “Writers' Union Looking Fit." Globe and Mail 28 Oct. 1974: 15. Print.

---. “Writers' Union Robust, Ready and Able." Globe and Mail 9 May 1977: 13. Print.

Friskney, Janet B., and Carole Gerson. "Writers and the Market for Fiction and Literature." Gerson and Michon 131-38.

Fuller, Danielle and DeNel Rehberg Sedo. "A Reading Spectacle for the Nation: The CBC and 'Canada Reads."' Journal of Canadian Studies 40.1 (2006): 5-36. Print.

Gadsby, H. F. "Snuggling Up to the Lawmakers.” Standard [Montreal] 6 May 1922: 17. Print. 
Garneau, Réne. "La Littérature.” Royal Commission Studies: A Selection of Essays Prepared for the Royal Commission on National Development in the Arts, Letters and Sciences. Ottawa: Edmond Cloutier, 1951. 83-97. Print.

Gaskell, Eric. Letter to William Arthur Deacon. Official. 16 Mar. 1939. William Arthur Deacon Fonds. Box 35A, File 11.

---. Letter to William Arthur Deacon. Personal. 16 Mar. 1939. William Arthur Deacon Fonds. Box 35A, File 11.

"Gathering in the Authors." Canadian Bookman 3.2 (1921): 22-24. Print.

Gerson, Carole. Canadian Women in Print: 1750-1918. Waterloo: Wilfrid Laurier UP, 2010. Print.

---. "The Canon Between the Wars: Field-notes of a Feminist Literary Archaeologist." Canadian Canons: Essays in Literary Value. Ed. Robert Lecker. Toronto: U of Toronto P, 1991. 46-56. Print.

Gerson, Carole and Jacques Michon. History of the Book in Canada. Vol. 3. Toronto: U of T Press, 2007. Print.

Gerson, Carole and Marie-Pier Luneau. "Social and Cultural Profile of Writers." Gerson and Michon 93-100.

Gibbon, John Murray. "Pages From an Informal History." Canadian Author 16.2 (1939): 5-6. Print.

"God Bless the C.A.A.!" Canadian Mercury 1.7 (1929): 134. Print.

“Government Prize for Literature.” Authors' Bulletin 8.1 (1930): 8. Print.

“Governor General's Award." Canadian Author 15.3 (1938): 17. Print. 
Grierson, I. M. Membership Application. 23 May 1974. Canadian Authors Association Fonds. Box 15, File 5.

“Group Asks \$10 Million For Cultural Centres.” Globe and Mail 22 June 1944: 11. Print. Hambleton, Ronald. Mazo de la Roche of Jalna. New York: Hawthorn Books, 1966. Print.

Hamilton, K., ed. Canada Writes! The Members' Book of the Writers' Union of Canada. Toronto: Writers' Union of Canada, 1977. Print.

Hammill, Faye. Women, Celebrity, and Literary Culture Between the Wars. Austin: U of Texas P, 2007. Print.

Harrington, Lyn. Syllables of Record Time: The Story of the Canadian Authors Association 1921-1981. Toronto: Simon \& Pierre, 1981. Print.

A History of the Canada Council. J.L. Granastein Fonds. Box 1995-0037/001, File 06.

"History of the Governor General's Literary Awards." n.d. William Arthur Deacon Fonds. Box 35A, File 3.

Holliday, Joe. Editorial. Canadian Author and Bookman 35.4 (1959-1960): 3. Print.

Hood, Robert Allison. "Welcome by Reminiscence.” Canadian Author and Bookman 18.2-4 (1942): 5. Print.

Howsam, Leslie. "The Study of Book History." The Cambridge Companion to the History of the Book. Ed. Leslie Howsam. Cambridge: Cambridge UP, 2015. 1-13. Print.

Irvine, Dean. Editing Modernity: Women and Little-Magazine Cultures in Canada, 19161956. Toronto: U of Toronto P, 2008. Print.

“John Buchan Buys a Book." Globe [Toronto] 27 Dec. 1935: 4. Print. 
Karr, Clarence. Authors and Audiences: Popular Canadian Fiction in the Early

Twentieth Century. Montreal: McGill-Queen's UP, 2000. Print.

---. "Writers and the Market for Fiction and Literature." Gerson and Michon 131-8.

Kennedy, Howard Angus. Letter to C.A.A. 23 Nov. 1935. William Arthur Deacon fonds. Box 35A, File 11.

---. "National Secretary's Report." Authors' Bulletin 8.1 (1930): 6-7. Print.

Kennedy, Roderick S. Letter to Pelham Edgar. 2 June 1938. William Arthur Deacon fonds. Box 29, File 16.

Killian, Laura. "Poetry and the Modern Woman: P. K. Page and the Gender of Impersonality." Canadian Literature 150 (Autumn 1996): 86-105. Print.

Kirkconnell, Watson. "More Light, Please." Rev. of Flight into Darkness, by Ralph Gustafason. Globe and Mail 26 May 1945: 19. Print.

---. "Presidential Address." Canadian Author and Bookman 33.2 (1957): 4-10. Print.

---. “Secretary's Report.” Authors' Bulletin 5.1 (1927): 5-7. Print.

---. A Slice of Canada: Memoirs. Toronto: U of Toronto P, 1967. Print.

Klages, Gregory. “'Will The Establishment Finance the Revolution?': Canadian Arts Advocacy Groups, the Federal Government, and Development of Arts Policies, 1963-1972.” Diss. York University, 2008. Print.

Kuffert, L. B. A Great Duty: Canadian Responses to Modern Life and Mass Culture, 1939-1967. Montreal: McGill-Queen’s UP, 2003. Print.

Leary, Patrick and Andrew Nash. "Authorship." The Cambridge History of the Book in Britain. Volume VI: 1830-1914. Ed. David McKitterick. Cambridge: Cambridge UP, 2009. 172-213. Print. 
Legate, David M. Stephen Leacock: A Biography. Toronto: Doubleday, 1970. Print.

Lennox, John W. 'New Eras: B. K. Sandwell and the Canadian Authors' Association, 1919-1922." English Studies in Canada 7.1 (1981): 93-103. Print.

Lévesque, Georges-Henri. "Address by the Vice-Chairman of the Canada Council, the Very Reverend Georges-Henri Lévesque." Council: Opening Proceedings, Ottawa, May 1957. Ottawa: Canada Council, 1957. 16-20. Print.

Litt, Paul. The Muses, the Masses, and the Massey Commission. Toronto: $\mathrm{U}$ of Toronto P, 1992. Print.

---. "The State and the Book." Gerson and Michon 34-44. Print.

"Little Man Letting Down the Longhairs." Vancouver Sun 1 June 1951: 27. Print.

Lonardo, Angela, Karen Lippold, and Suzanne Sexty. "Literary competitions Quebec / Quebec Literary Competition." Literary Awards in Canada 1923-2000. n.d. Web. 16 Oct. 2014.

---. “Concours littéraires du Québec / Quebec Literary Competition." Literary Awards in Canada 1923-2000. n.d. Web. 15 July 2016.

"Lord Tweedsmuir 1935-1940." The Governor General of Canada. n.d. Web. 20 Feb. 2015.

"Luxury Profession.” Canadian Author \& Bookman 17.1 (1940): 14. Print.

MacArke, J. V. “Canadian Literature Having New Birth.” Mail and Empire 10 Nov. 1936: 6. Print.

MacMurphy, Marjory. "Fiction.” The Year Book of Canadian Art, 1913. Comp. Arts and Lettters Club of Toronto. Toronto: J. M. Dent \& Sons, n.d. 53-60. Print. 
MacSkimming, Roy. The Perilous Trade: Publishing Canada's Writers. Toronto: McClelland \& Stewart, 2003. Print.

McCarthy, Pearl. “Artists Conceive National Policy.” Globe and Mail 17 June 1944: 16. Print.

McCourt, Edward. "Canadian Letters." Royal Commission Studies: A Selection of Essays Prepared for the Royal Commission on National Development in the Arts, Letters and Sciences. Ottawa: Edmond Cloutier, 1951. 67-82. Print.

McDowell, Franklin Davey. “Governor General’s Awards Board. Chairman's Report, Years 1949-1951, inclusive.” 1951. William Arthur Deacon fonds. Box 35A, File 5.

McFarlane, Leslie. “Canadian Authors Bumped.” Letter. Mail and Empire 4 July 1931: 6. Print.

"Minutes of the National Executive Committee of the Canadian Authors' Association, April 29, 1944." Charles Clay Fonds. Vol. 4, "Canadian Authors Association 1943-1944" File.

“A Modern Viceroy.” Canadian Author 12.3 (1935): cover. Print.

Montgomery, L. M. The Selected Journals of L.M. Montgomery: Volume III: 1921-1929. Ed. Mary Rubio and Elizabeth Waterston. Toronto: Oxford UP, 1992. Print. Moore, Christopher. “The Writers' Union of Canada 1973-2007.” The Writers' Union of Canada. The Writers' Union of Canada, 2007. n.d. Web. 28 Oct. 2015.

Moritz, Albert and Theresa Moritz. Leacock: A Biography. Toronto: Stoddart, 1985. Print. 
Moss, Laura and Cynthia Sugars, eds. Canadian Literature in English: Texts and Contexts. Vol. 2. Toronto: Pearson, 2009. Print.

Mount, Nick. When Canadian Literature Moved to New York. Toronto: U of Toronto P, 2005. Print.

“Mr. Stead's Theory.” Editorial. Manitoba Free Press 4 Aug. 1924: 8. Print.

Murray, Heather. "The Canadian Readers Meet: The Canadian Literature Club of

Toronto, Donald G. French, and the Middlebrow Modernist Reader.” Papers of the Bibliographical Society of Canada 46.2 (2008): 149-83. Print.

"Mysteries Boom." Editorial. Canadian Author and Bookman 21.2 (1945): 4. Print.

Ostry, Bernard. The Cultural Connection: An Essay on Culture and Government Policy in Canada. Intro. Robert Fulford. Toronto: McClelland and Stewart, 1978. Print.

“Ottawa Branch Report.” Authors' Bulletin 3.1 (1925): 9-10. Print.

“Ottawa, Please Note!” Canadian Author 16.2 (1939): 6. Print.

Palmer, Bryan D. Working-Class Experience: Rethinking the History of Canadian Labour, 1800-1991. Toronto: McClelland, 1992. Print.

Parker, George L. "Authors and Publishers on the Offensive: The Canadian Copyright Act of 1921 and the Publishing Industry 1920-1930." Papers of the Bibliographical Society of Canada 50.2 (2012): 131-85. Print.

Pennee, Donna Palmateer. "Culture as Security: Canadian Foreign Policy and International Relations from the Cold War to the Market Wars." International Journal of Canadian Studies 20 (Fall 1999): 191-213. Print.

Pereira, Frederick. Letter to Pelham Edgar. 8 Nov. 1937. William Arthur Deacon Fonds. Box 35A, File 11. 
Perry, Anne Anderson. "Report of the Membership Committee Toronto Branch." May 1932. Canadian Authors Association Fonds. Box 27, File 33.

"Poetry Magazine Wanted." Canadian Author 12.4 (1935): 6-7. Print.

“Printers or Authors?" Editorial. Canadian Bookman 1.3 (1919): 6-8. Print.

"Proposed Poetry Magazine." Canadian Author 11.4 (1934): 14. Print.

"Provisional Constitutions and By-Laws." Canadian Bookman 3.1 (1921): 4-7. Print.

"Provocative Criticism." Canadian Author and Bookman 20.1 (1944): 24. Print.

"Publishers and Authors." Editorial. Canadian Forum 2.15 (1921): 452-3. Print.

"Publishers-Authors-Booksellers." Bookseller \& Stationer 37.5 (1921): 40. Print.

Radway, Janice A. A Feeling for Books: The Book-of-the-Month Club, Literary Taste, and Middle-Class Desire. Chapel Hill, NC: U of North Carolina P, 1997. Print.

Redfern, Shuldham. Letter to Pelham Edgar. 6 May 1937. William Arthur Deacon Fonds. Box 35A, File 11.

Report of the Royal Commission on National Development in the Arts, Letters and Sciences 1949-1951. Ottawa: Edmond Cloutier, 1951. Print.

“Resolutions Committee.” Authors' Bulletin 4.1 (1926): 14-6. Print.

Reyburn, Wallace. “Canadian Authors' Dilemma." National Home Monthly July 1950:

12-13, 24-5. Print.

Rifkind, Candida. Comrades and Critics: Women, Literature, and the Left in 1930s

Canada. Toronto: U of Toronto P, 2009. Print.

---. "Too Close to Home: Middlebrow Anti-Modernism and the Sentimental Poetry of Edna Jacques.” Journal of Canadian Studies 39.1 (2005): 90-114. Print. 
Roberts, Gillian. Prizing Literature: The Celebration and Circulation of National Culture. Toronto: U of Toronto P, 2011. Print.

Robson, Albert. Letter to Pelham Edgar. 20 Sept. 1935. William Arthur Deacon Fonds. Box 35A, File 11.

---. Letter to Pelham Edgar. 18 Nov. 1935. William Arthur Deacon Fonds. Box 35A, File 11.

Rohmer, Richard, Dalton Camp and Marsh Jeanneret. Canadian Publishers \& Canadian Publishing: Royal Commission of Book Publishing. Toronto: Queen's Printer for Ontario, 1973. Print.

Rose, Mark. Authors and Owners: The Invention of Copyright. Cambridge: Harvard UP, 1993. Print.

Rubin, Joan Shelley. The Making of Middlebrow Culture. Chapel Hill, NC: U of North Carolina P, 1992. Print.

Rubio, Mary Henley. Lucy Maud Montgomery: The Gift of Wings. Toronto: Doubleday, 2008. Print.

Sandwell, B. K. “Another Book Week.” Editorial. Canadian Bookman 4.6 (1922): 155-6. Print.

---. “Canadian Authors.” Reply to letter of Leslie McFarlane. 9 July 1931: 6. Print.

---. “Canadian Book Week: November 21-26.” Bulletin 1 [1921]: n. pag. Print.

---. “The Canadian Copyright Act.” Queen's Quarterly 29.2 (1921): 182-8. Print.

---. “The New Copyright Act." Authors' Bulletin 9.1 (1931): 35-7. Print.

Scott, Duncan Campbell. “A Message from the President." Authors' Bulletin 9.1 (1931): 4. Print. 
Scott, F. R. "The Canadian Authors Meet." McGill Fortnightly Review 2.9-10 (1927): 73. Print.

Smith, A. J. M. "Wanted-Canadian Criticism." Canadian Forum 8.91 (1928): 6001. Print.

“"Something's Going to be Done." Editorial. Canadian Author 13.2 (1935): 3-5. Print.

“Story of Canadian Authors’ Association.” Gazette [Montreal] 19 Nov. 1921: 23. Print.

Stead, Robert. "Have We a Literature: From Mr. Robert Stead's Presidential Address to the Canadian Authors' Association." Manitoba Free Press 4 Aug. 1924: 8. Print. ---. "Literature as a National Asset: A Radiographed Message." Canadian Bookman 5.12 (1923): 343. Print.

---. "Mr. Stead's Theory: A Reply by Robert Stead to an Article Which Appeared in the Literary Section of Last August Under the Above Title." Manitoba Free Press 6 Oct. 1924: 5. Print.

Stiling, Frank. "The Governor General's Awards Board." Canadian Author and Bookman 30.3 (1954): 4-5. Print.

Stringer, Arthur. “Our Authors Get Together.” MacLean's Magazine 15 Apr. 1921: 24-5, 42. Print.

Struthers, James. No Fault of Their Own: Unemployment and the Canadian Welfare State 1914-1941. Toronto: U of Toronto P, 1983. Print.

Szeman, Imre. "Introduction: A Manifesto for Materialism.” Essays on Canadian Writing 68 (Summer 1999): 1-18. Print. 
Thomas, Clara and John Lennox. William Arthur Deacon: A Canadian Literary Life. Toronto: U of Toronto P, 1982. Print.

"Thumbnail History of the Canadian Author \& Bookman." Canadian Author and Bookman 41.4 (1966): 18-19. Print.

Tippett, Maria. Making Culture: English-Canadian Institutions and the Arts Before the Massey Commission. Toronto: U of Toronto P, 1990. Print.

“Toronto Branch Report.” Authors' Bulletin 3.1 (1925): 13-14. Print.

Trueman, A. W. "The 1959 Governor-General's Awards." Canadian Author and Bookman 36.1 (1960): 18-19. Print.

“Tweedsmuir Awards.” The Globe and Mail 3 July 1937: 23. Print.

Tweedsmuir, Lord [John Buchan]. Letter to Pelham Edgar. 9 Feb. 1937. William Arthur Deacon Fonds. Box 35A, File 11.

Vautour, Bart and Christl Verduyn. "Nota bene; or, notes towards a poetics of work..." Public Poetics: Critical Issues in Canadian Poetry and Poetics. Ed. Bart Vautour, Erin Wunker, Travis V. Mason, and Christl Verduyn. Waterloo: Wilfrid Laurier UP, 2015. 333-9. Print.

Vesey, T. M. "Canadian Literature and the Lower Criticism." Canadian Bookman 5.4 (1923): 91-3. Print.

---. "Literature-A Cult or A Commodity?" Manitoba Free Press 28 Oct. 1922: 18. Print. Vincent, Josée. "Faire voir pour faire (re)connaître: le travail de promotion de la Société des écrivains canadiens, de 1936 à 1960.” Voix et Images 27.2 (2002): 254-69. Print. 
---. “Un premier regroupement 'professionnel' d'écrivains au Québec: la section française de la Canadian Authors Association (1921-1936)." Lieux et réseaux de sociabilité littéraire au Québec. Montréal: Éditions Nota Bene, 2001. 275-333. Print.

---. "Les professionnels du livre à la conquête de leur marché: les associations professionnelles dans le champ littéraire au Québec.” Diss. University of Sherbrooke, 2002. Print.

Vipond, M. "The Canadian Authors' Association in the 1920s: A Case Study in Cultural Nationalism.” Journal of Canadian Studies 15.1 (1980): 68-79. Print.

Weingarten, J.A. "Modernist Poetry in Canada, 1920-1960." The Oxford Handbook of Canadian Literature. Ed. Cynthia Sugars. Oxford: Oxford UP, 2016. 314-36. Print.

West III, James L. W. American Authors and the Literary Marketplace since 1900. Philadelphia: U of Pennsylvania P, 1988. Print.

Widdemer, Margaret. "Message and Middlebrow.” Saturday Review of Literature 18 Feb. 1933: 433-4. Print.

"What is Wrong With the C.A.A.?" Canadian Author and Bookman 43.4 (1968): 15. Print.

Whittaker, Herbert. "Canada Council Calls Conclave of Culture to Consider the Cash." Globe and Mail 28 Dec. 1957: 13. Print.

Williams, Susan S. "Authors and Literary Authorship." A History of the Book in America. Volume 3: The Industrial Book 1840-1880. Ed. Scott E. Casper et al. Chapel Hill, NC: U of North Carolina P, 2007. 90-116. Print. 
Woodcock, George. "The Mermaid Inn: The Liberation of Canada's Writers." Globe and Mail 10 Mar. 1979: 6. Print.

---. "On the Resources of Canadian Writing." Royal Commission on Book Publishing: Background Papers. Toronto: Queen's Printer and Publisher, 1972. 61-85. Print.

---. Strange Bedfellows: The State and the Arts in Canada. Vancouver: Douglas \& McIntyre, 1985. Print.

York, Lorraine. Literary Celebrity in Canada. Toronto: U of Toronto P, 2007. Print. ---. Margaret Atwood and the Labour of Literary Celebrity. Toronto: $\mathrm{U}$ of Toronto P, 2013. Print.

"You Asked." Canadian Author and Bookman 49.4 (1974): 19. Print. 